

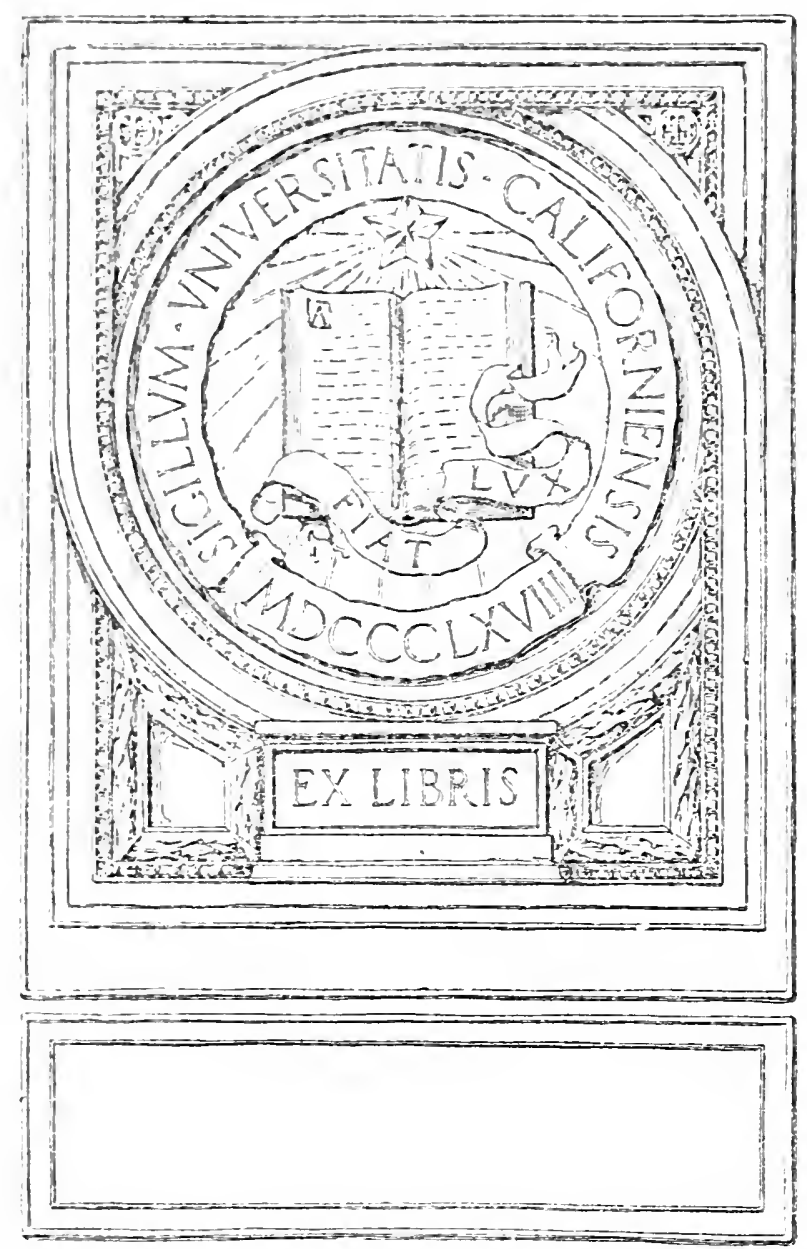






ANGASS MANUAI 



\section{ANGASS MANUAL}

\section{GRAMMAR AND VOCABULARY}

BY

\section{H. D. FOULKES}

CAPtain (LATE R.F.A.), POLITICAL OFFicer, Nigeria

\section{LONDON}

KEGAN PAUL, TRENCH, TRÜBNER \& CO. LID BROADWAY HOUSE, 68-74 CARTER LANE, E.C.

AND 25 MUSEUM STREET, W.C. 
The rights of translation and of reproduction are reserved

Priuted by Ballantren, Hanson \& Co. at the Ballantyne Press, Edinburgh 


\section{PREFACE}

BeING struck with the many similarities between Angass and Hausa, I wrote this book in its present form to circulate amongst students of Hausa in order to obtain an opinion as to whether they should be regarded as cognate languages. I had intended, if this opinion were favourable to my view, to have added, before publication, some chapters on syntax and some more stories. The manuscript, however, was sent home, where I eventually overtook it, but by that time I was informed that I was to be transferred to another Province. Though I knew Angass fairly well, my knowledge of it was not sufficiently intimate to allow me to make any additions on my own responsibility - that is, without the assistance of, or a reference to, Angass-speaking men; but, having gone as fall as I had done, I decided to publish the manuscript as it was, rather than abandon it altogether.

This will account for the fact that the work is not entirely a purely Angass Manual, but that it also contains various discussions of Hausa analogies and difficulties.

The spelling I have adopted is not as exact as it might be, but, for the object I had in view in circulating the manuscript, it did not much matter whether. I spelt the word as dèm or dẹm, and I wanted to make the manuscript as little troublesome to read as possible.

Further, the pronunciation of words varies among the different clans of the Angass tribe; in the Hills especially the vowels are very much broader than in the Plains; 
thus in the Hill dialects the word for ' a head' is kā, and in the Plain dialects it is kē; and in the same way dŭm is heard in different places as düm, děüm, and dẹ̆m.

It is not always easy to find the exact English equivalent for a native word, and in order to make the meaning clearer I have given, in the Vocabulary, a number of sentences, so that the reader may gather the sense for himself from the context. These sentences, too, fulfil a further purpose, for from them one may infer, to some slight extent at any rate, the native attitude towards various subjects. Thus the Angass philosophy as regards women may be gathered from such a sentence as yĭn kĕ tã, măt-dă chĕung, bĕ tŏng, 'the remedy, if a woman is obstinate or obstreperous, is just to sit tight'; the relations between the sexes is given by, yī măt-nĭ, kēpăng-yī kā dŭng, yī nē gŭrm-mă, bě yī sĭt pī mē ? yī wŭl fŭng kō yī pŭt! ' Hi ! you woman, you have no modesty whatever ! you see men (sitting here), so why do you come passing by ? go through the back door and clear out!' ; gōl kè dèn gō rōt băng, 'justice comes down on even the man she loves,' gives a good idea of their own impression of the work of their courts; mă pün zīn gŭrm pī rōt kădăk, 'one by no means believes a man merely because one likes him,' shows their sound practical common sense; Něn yē děn kī kō nyì chăk tōm dì, ' God put in the liver to collect the blood,' gives an idea of their notions of physiology; gwŏ-dă chĭn tălīt, chĭn bì-chě kě tăknă, gyī măt, 'the man has committed adultery, he can do nothing now, but has become like a woman,' i.e. he has lost all his rights to participating in the religious ceremonies and sacrifices; this shows the strictness of their moral code, which is further accentuated by wēr két két tŭng kè măt kě gworchĕ, "it is absolutely forbidden even to touch another man's wife.' 
The Angass, of course, cannot read or write, so that I have had to reduce what I heard spoken to a written form. Nearly every sentence in the following pages occurred in the ustal conrse of office work or conversation, and was noted down at the time it was uttered.

The language is so simple in construction that I am hoping a study of it may help in elucidating the groundwork of the grammar of more elaborated Negro languages.

The correction of the proofs has been carried out at odd times and under certain difficulties. Part of it was done while at home on leave; part after my return to Nigeria ; and the rest has been finished while on active service in the German Cameroons.

$$
\begin{aligned}
& \text { H. D. FOULKES, Capt. (Late R.F.A.), } \\
& \text { Political Officer, Nigeria. }
\end{aligned}
$$

Mora, October 17, 1914. 



\section{EXPLANATION OF DIACRITICAL MARKS}

Is general all vowels are pronounced as in Italian, and all consonants as in English; the following have special uses :-

$\overline{\mathrm{ng}}=$ the very nasal ' $\mathrm{n}$ ', as in ' hă $\overline{\mathrm{ng}}$.'

$\dot{n}=$ the slightly nasal ' $\mathrm{n}$ '; as the last one in the French ' nŏn.'

$\ddot{u}$ gives mole of the ' $u$ ' sound than is recognised in ' $\overline{\mathrm{eu}}$.'

$\overline{\mathrm{g}} \mathrm{h}=$ the Alabic $\dot{\mathcal{E}}$.

$\ddot{o}$ as in German.

$\cdot \mathbf{d}, \mathbf{b}$, very rarely used, to distinguish, from the ordinary ' $d$ ' and ' $b$,' two sounds, emitted by a sort of holding of the breath and then a slight explosive enunciation.

a = a quickly pronounced 'ěă,' as 'läng ' = 'lěăng.'

$\overline{\mathrm{eu}}=\mathrm{a}$ diphthong pronounced as in the French ' $j$ ' ai eu.'

The sign - represents the long sound, and ' the short one. 'Thus 'ābăt'=our 'ah! but'; and 'ăbūt'=our ' a boot'; the sign' shows where the accentuation falls.

A long and a short mark = over a vowel indicates that the vowel is pronounced either long or short according to the requirements of the euphony of the context, e.! ' nyī.'

A long mark over two vowels indicates them to be at diphthong, and not to be sounded separately, e.g. ' che euk,' i.e. the $\overrightarrow{\mathrm{eu}}$ is a diphthong pronounced short. 



\section{CONTENTS}

\section{CHAPTER I}

The Noun; Adjective; the Article; Personal Pronouns; Pronominal Prefixes; the Verb 'dō'; Plurals; 'to have'; the Interrogative . . 1

\section{CHAPTER II}

Demonstrative Pronouns; the Relative Pronoun; the Interrogative Pronouns; the Genitive; the Negative; 'there is,' 'there are' . . . 8

\section{CHAPTER III}

The Indefinite Pronoun; ' kō'

\section{CHAPTER IV}

Euphony; Gender'; Reciprocal Pronouns; 'shě̌k'; Possessive Pronouns; Reflexive Pronouns . 18

\section{CHAPTER V}

Noun Agent; ' bi ně'= 'abinda'; the Hausa ' $d \breve{a}$ '= 'who,' 'which'; Adjectives; '-less'; Colours.

\section{CHAPTER VI}

Preliminary remarks on the Verb; the Verb; Pronominal Prefixes ; 'tě '; 'găt'. . . . 


\section{CHAP'TER VII}

'The 'Continuous' Tense; compared with the Hausa; 'pó'

\section{CHAP'TER VIII}

'The 'Future'; Verbs with two Objects; the 'Narrative Past' Tense; the 'Imperative'; the 'Subjunctive'; the 'Infinitive'; the 'Passive'; form equivalent to the Hausa ' a-tsugune'; 'kă'; the equivalent of the Hausa Passive Terbal Noun; 'dhrr'

\section{CHAPTER IX}

The Prepositions; Nouns used Prepositionally; 'ol' ; 'if'; the 'Conditional'; 'but'; 'before'; 'kŭt'; 'dĭdhĭr'

\section{CHAPTER X}

'Yet,' 'still'; 'when?' 'where?' ; 'from'; 'now' ; 'together' ; 'near'; 'far' ; 'thus'; 'how?'; 'how'; ' exactly'; 'slowly'; 'quickly'; ' truly'; 'for ever'; 'only'; 'yes'; 'perhaps'; 'whether' ... or'; 'certainly'; 'no'; 'unless'; 'again'; 'at once'; 'sort of'.

\section{CHAPTER XI}

Comparison of Adjectives and Adverbs; 'rather'; 'better'; the 'Superlative'; 'too'; 'as much as'; discrimination of Gender .

\section{CHAPTER XII}

The Numerals; Fractions ; 'to measure'; 'cheap'; 'dear' 


\section{CHAP'IER XIII}

PAGE

The Indefinite Pronouns; Salutations and Interviews

CHAPTER XIV

The Seasons; Times of the Day . . . . 80

\section{CHAPTER XV}

'To be like'; 'to become'; Relationship . . 84

\section{CHAPTER XVI}

Phrases and Idioms

88

\section{CHAPTER XVII}

Tales and Notes: 'The Hare and the Python'; 'The Partridge and the Dog'; 'The Kurkutan and the Crown Bird '; 'The Tortoise and the Hare' ; 'The Hare goes Hunting' ; 'The Guinea-Fowl and the Hare'; 'The Monkey, the Leopard, the Hare, and the Tortoise'; Free translations of the last five.

\section{CHAPTER XVIII}

Further points of similarity with Hausa; points of dissimilarity ; 'tuntuni,' and 'chacha' derived from Angass; a Characteristic of the People to be noted; the Language very simple compared to what it might be . 



\section{INTRODUC'TION TO THE ANGASS MANUAL}

The Angass language is essentially a monosyllabic one. There are not many words of two syllables, and only a few that I know of, of three, e.g. 'kŭrkŭjī,' a 'fable.' Most of the dissyllables are either compounds or' are of foreign origin; nevertheless, after allowing for these, there are a few which probably belong to the language proper', such as 'gurmā' = 'an idiom,' or ' niceties of speech '; 'chádhèr' = 'a mistake'; 'bărăng' = 'trouble,' etc. 'The present Angass people were for a time in Jukon territory, if not at Kororofa itself, or its immediate neighbourhood; and they were also in Bornu, and it may turn out that these dissyllables belong to one of these places. The grammar is very nearly as simple as a grammar can be; and the only difficulty - but it is a very real one-in the colloquial is the apparently capricious employment of a large number. of particles, the use of which, though immaterial from a grammatical point of view, is, however, necessary in practice, for without them the sentence certainly loses its flavour, and seemingly some of its sense, in that an ordinary man cannot understand a phrase unless it is enunciated exactly in the way he is accustomed to hearing it, and the omission or transposition of a word bothers him considerably.

The outstanding features of the language are :-

1. There is no verb 'to be.'

2. The root of the verb, as in Hausa, undergoes no inflection. 
3. There is no infinitive, a corollary probably of 2.

4. The use of pronominal prefixes, as in Hatusa.

5. One form of these prefixes loes duty for all the tenses, as it loes to a very large extent in Hausa.

6. 'The 'Continuous 'Tense,' corresponding to the same curious construction in Hausa.

7. The very complicated usage of the indefinite pronouns.

8. The extraordinary adaptivity of the particle ' $k \bar{o}$.'

9. The extensive use of particles, more baffling, to a beginner at any rate, than the Greek, ' $\mu$ '́ ',' ' $\gamma \alpha$ á $\rho$ ' ' $\delta \epsilon$,' etc.

10. The absence of any passive forms of the verb; our passive being rendered by an impersonal pronoun, also like the Hausa.

11. A very copious vocabulary.

12. The flexibility of the language in spite of its paucity of forms.

The language, from being monosyllabic and from the simple construction of its grammar, is primitive in the extreme, very much more so than any of the better known ones, and that, to some extent, is a measure of its antiquity; that is to say, it is more ancient than, for example, the Jukon, Hausa, or Jarawa languages.

The country, from its nature and fertility, has probably always been a desirable habitation, and has always been occupied, and it would appear that all the various tribes, who, coveting the district, have in turn ousted or absorbed their predecessors, have evidently taken over the language of their new settlement, which through all vicissitudes has persisted till now.

This language is itself either the original or a valiation of a group of dialects which are spoken by the neighbouring tribes of the Montoils, Thal, Chip, Ankwe, Sura, and Mushere; and possibly others may be found in addition. 
In very many essential words, but more especially in its construction, it bears a very great similarity to Hausa, which leads to the fair inference that the latter is derived from Angass; for, so far as we at present know, the Angass and its varieties are indigenous, whereas the Hausas are immigrants. This needs, however, the not far-fetched assumption that an Angass-speaking people were settled in the present country of the Hausas, when the latter first arrived there about 1000 year's ago. The Hausas were a more enlightened race than these Angass, and, having in all probability been in contact with the Arabs in the Far East, whence they came, they had to retain many phrases and idioms of their own native and the Arabic languages, which were essential to their mode of life and thought, and which they did not find in the simple local language which they had inevitably to learn. A portion of the people would have remained and been absorbed by the invasion, but a goodly proportion would have separated themselves and retreated to the fastnesses of the mountains, where they could maintain the purity of their tongue and customs.

This view is, of course, only tentative, and the matter can only be definitely cleared up by a further knowledge not only of the other dialects, but also of the history of Bauchi Province during the last thousand years, the former, needless to say, being by far the easier task of the two; but it is a view that will account for the similarity of the syntaxes, and also for the superficial dissimilarity of the vocabularies in the main; but because of the similarity, I have taken some trouble in the study of the language, and present the result in the following pages.

The examples given in the Grammar are taken from the dialect of the Plain Angass. This, in so far as so primitive a language can be said to be polished, is the most polished of them all, though probably the Hill dialects, as not being so accessible to outside influence, would 
be more useful for my present purpose, in that their idioms would adhere more nearly to the original forms. 'Thus even in the Vocabulary, which, though of importance, is only of a minor importance in the descent of a language, the Plain Angass for 'a sheep' is 'mà'; but in the Hills it is 'tüm,' which is mole like the Hausa 'tumkia'; and 'again the Plain Angass for 'all' is 'kěsheük, but in Thal and Hill Angass it is 'dǔk,' or generally more emphatically ' dŭk dŭk' = Hausa ' $d u l_{i} \alpha$,' and they do not know 'kěsheuks.' Every sentence given has been tested by at least three Angass men separately; and in most cuses the simplest correct form has been selected to exemplify the rules, in the exposition of which idiomatic phrases scarcely have a place.

Hausa is like no other known language in its construction, and it is only reasonable to suppose that among the host of tongues in the Protectorate of $\mathrm{N}$. Nigeria alone, we shall find the group to which it belongs. In Bauchi Province itself there are estimated to be sixty-four different languages - not dialects-and it is quite possible that among them we may find one showing a greater affinity to Hausa even than Angass, though I doubt it.

It will be noticed that there are several digressions in this Grammar and many references to Hausa, but as my object is not only to lay a foundation for the study of Angass, but also to show its relationship to Hausa, these will be forgiven. What I have already accomplished is sufficient for this purpose, but before I spend any more time over it I should like the opinion of those whose knowledge of Hausa is more intimate than my own, and to these I now submit it for their criticism, and if I am correct, then Hausa is a Negro and not a Hamitic language.

H. D. FOULKES. 


\section{G R A M M A R}

\section{CHAP'TER I}

1. Nouns: general notes. With few exceptions the nouns (and other parts of speech) are monosyllabic, and, though this is so, it may be said that intonation is not a feature of the language.

2. If a noun has several meanings, these are not differentiated by tones, but by tacking on another worl with a meaning similar' to the one required. Thus Sheük means 'body' and 'speech.' 'Body' is always sheūk by itself; 'speech' again is also frequently sheük, but more of ten sheük-tǒk, where tǒk = 'speech,' ' talk.' Again, ěs is 'egg,' and 'flour.' As a rule, used by itself it indicates 'flour,' and ěs-kī ='egg,' where $\mathbf{k} \overline{\mathbf{i}}=$ ' 'fowl.' $\breve{\mathbf{E}} \mathrm{s}$, however, is one of the very few worls in which an intonation can be heard, but, in spite of that, ès-ki is used preferably to the intonation to mean ' egg.'

3. 'The nouns appear to be the root forms of the language, i.e. they are not derived from verbs, but on the other hand verbs are formed from them by the addition of pronominal prefixes (see chap. vi. paras. 1-4).

4. Nouns have a regular plural formation, viz. by the addition of '-mă' at the end of the word, e.\%. măt=a woman, măt-mă = women (see para. 20, where two apparent exceptions are dealt with).

5. Nouns undergo no inflexion for gender or case. If attention is to be called to the gender of an object, it is 
' ioue by means of worls corresponding to our 'male' and 'female' (see chap. xi. paras. 8-11).

6. In the genitive the object possessed comes first, e.1. brüng gworlong = (the) horse (of the) king. This can also be expressed brüng kĕ gwolong, where kĕ $=$ the prep. 'of.'

7. The Arjective follows the noun. It has no inflexion. For its comparison, see chap. xi. paras. 1, 2, and 5.

8. There is no Tndefinite Article ' a,' 'an' in Angass.

9. There is a Definite Article 'the' =' -dă,' though it is not always used where we should use it, but it corresponds to the 'nan,' and ' $-n$ ' of the Hausa in such phrases as 'labari-n yalii lie nan' and 'a-11uri-n' which in $\begin{array}{llllllll}1 & 2 & 3 & 4 & 5 & 1 & 2 & 3\end{array}$

Angass would be 'kwŏmfwŏt kĕ lěók dō dă'; and kă pí -dă, numeral for numeral.

3

Thus 'gurrm '=؛ a man,' or 'the man.'

and 'măt' = 'a woman,' or 'the woman.'

If, however, great stress is laid on the 'the,' as in 'the man' or 'the particular man,' then '-dă' is used. Thus-

'The man went and the woman ran' = gŭrm mĕt, măt sū.

But 'the woman whom I saw yesterday is very thin' would be

$=$ in Hausa, mata-n da na-gani jia ramamia dayaura.

10. This '-dă' is so definite as almost to be classed under the demonstrative pronouns (see chap. ii. paras. $1,2,3)$.

11. The Personal Pronouns are-

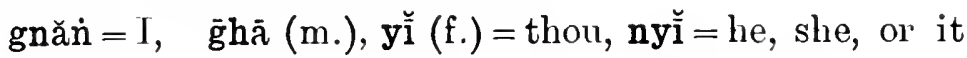
mŭn $=$ we, wŭn $(m$. and $f$.) = ye, mă = they.

They are used $(a)$ when standing alone by themselves, 
(b) as subject to our verb ' to be,' (c) as the olject groverned by verbs or prepositions, (ll) as the dative - when they are placed af ter the accusative.

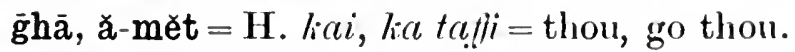

wē kě chinn? =H. wa zei yi $?=$ who will do it? Ans. mŭn $=$ we.

ă-pün nyī gnăn = give it (to) me.

kě mět kĕ wŭn $=$ he will go with you.

12. As these are nominative, accusative, and dative, ambiguities will occur, especially in the $3 \mathrm{rd}$ pers., and to obviate this, 'sheuk' is used, where necessary, as the object of a preposition, and 'dí' as the object of a verb.

Thuns-

'Don't beat him with it,' is not 'măn ă-cheūk nyī shr nyī,' but 'măn ă-chěuk nyī shǐ shēuk.'

'See this axe! I killed him with it' = 'ă-nē săp-nĭ, ăn-tū nyi shǐ sheukk'; again, 'put it down' $=\mathrm{H}$. aje shi; this is not 'dèn nyi,' for that would equal the Hausa 'aje masa' (the dative), but 'děn dí.'

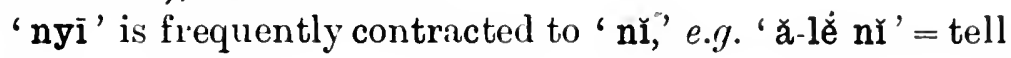
him.

13. The Verbs undergo no inflexion for tense or per'son (see, however, ch. viii. para. 5). The former is indicated by the context, and the latter by a set of pronominal prefixes as in Hausa. Possibly these pronominal forms can be regarded as inflexions, preficed, instead of suffixed, as with us. For instance, in English we have 'I go,' 'thou go-est,' 'he go-es' where the inflexions '-est,' and '-es' (or '-s') are suffixed, and it may be that for the same reason that in English we do not say ' the man go,' so in Hausa they do not say 'mutum taffi', and just as we must say 'the man go-es,' so they say 'mutum ya-tafji'; that is, ' $n a-$,' ' 'ka-,' 'ya-,' etc. are the personal inflexions of the verb, prefixed, instead of suffixed as with us. Even in English, where the verb has a sufficiently distinct 
personal inflexion, the pronoun may be omitted, as in telegrams, e.!. 'am going to London to see Jones; leaves for India next week'; and in former days 'hast seen my horse?' was complete and ample. Hausa civilisation being more primitive than English, and there being less need for accuracy, the language simplifies itself as much as possible, and where the inflexion sufficiently denotes the person it does not cumber itself with an unnecessary nominative. 'Thus, 'ya-tafij'=' has gone'; 'ya-' and 'has' can only refer to the 3rd pers. sing., and there is no absolute necessity to say 'shi ya taffi' or. ' he has gone.' The same applies in Angass.

14. These prefixes are:-

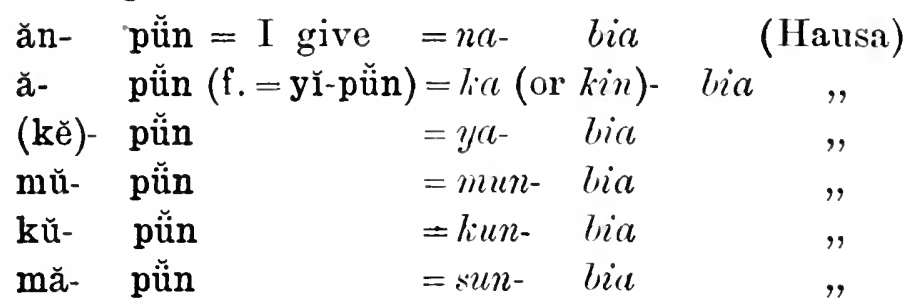

It will be noticed that this construction is exactly the same as in Hausa.

15. In the Burrum (Kannam) language these personal pronouns are more like those of Hausa, e.g. $\breve{a} m, g \breve{a}$, sh $\breve{\imath}$

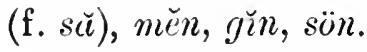

16. These prefixes will be more fully dealt with under 'The Verb,' but it might be noticed here that in the 3rd pers. sing., 'kĕ pün' = 'he gives,' or' 'he will give.' For what we call the preterite and perfect, 'he gave,' 'has given,' is in Angass 'pün' pure and simple without any pronoun, but only in the preterite and perfect 3rd pers. sing.

17. There is no verb 'to be,' but a word ' dō' is used where emphasis is required, or where our definite article ' the' would be necessary.

nyi gwolonng = he is a king, 
nyĩ dō gworlong = he is the king,

nyì-dă do gworlong = this is the king.

(Cf. Hausa shi seriki ne, and shi ne serili.)

It is probable that the "substantive verb" " $n e$ ' in Hausa, with its feminine form ' 'lhe, is not the verb 'to be' at all, but the same in origin as the ' $n e$ ' and 'che' in 'wane,' 'warke.' For the other "substantive verb," 'lie,' see chap. xuiii.

18. This ' $d \bar{o}^{-}$' is comparable in some respects with the Hausa 'lie'; 'brüng dō dā?'="lloli lie nan ?'=' is this the horse?' 'nyĩ dō dă' = 'shi lie nan' word for word.

' nyì dō dă' is also used in the same idiomatic sense as 'shi lie nan' = 'all right,' ' that will do,' etc.

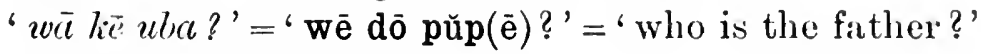

('who is a father' ='wē pŭp(ē) ?')

19. The noun is the direct subject of the verb, unlike Hausa, unless we look on the pronominal prefixes as part of the verb instead of as pronouns (see para. 6).

gurrm mět $=$ the man went.

gwollong pün zŭm gnăn = the king gave a present to me.

20. The plurals are formed very simply by adding '-mă' to the singular : ' măt-mă' = women, 'brüng-mă' = horses.

There are two apparent exceptions; 'yèm,' 'a boy,' becomes 'jěb-mă' or sometimes 'jèp-mă.' In all the other dialects 'yèm' is not known, but 'jëb' is the only word for 'a boy,' and the Angass, wherever they may have got hold of 'yerm,' have reverted to the original for the plural form 'jêb-mà.' It need hardly be insisted on that people in such a primitive state do not realise that they have a rule and are following it, when they say 'jěb-mă' or ' măt-mă.' They merely know that when any one means 'women' or 'boys' he says 'măt-mà' and 'jěb-mă.' 'Yèm-mă' is quite incomprehensible to them, and they do not know the word at all, and it was not 
till after quite a little trouble that they realised it might stand for 'boys,' hut, as they said, "it doesn't."

'Rip,' 'a young girl,' becomes 'rēb-mă' in the plural, possibly from a similar cause, though I have not yet traced ' rēb' in the singular.

21. As in Hausa, if there is a word in the sentence which in itself connotes the plural, the singular form of the noun, etc., is used; thus, 'four year's' is ' $\mathbf{y} \mathbf{i} \mathbf{f i r}$,' not 'yī-mă fīr'; 'many men' = 'gŭrm dŭng' not 'gŭrm-mă dŭng.' These plural forms are heard, but they have a different meaning, thus ' yì mă fïr' is 'years, they are four,' etc. At the same time the plural forms are admissible as such, but they are not 'gurnà' or good Angass.

22. 'This suffix '-mă' is merely the 31 d pers. plural of the personal pronoun (see para. 4). It is also used as an imper'sonal pronoun, and is = 'people,' 'folk,' 'one,' etc., like the French 'on' in 'on dit'= 'people say', and, as such, forms the phrases which render our passive, like the Hausa ' $a$ ' (chap. vii. para. 13).

'brüng-mă' = 'horse they' =' horse people' or 'horse folk' = 'horses.'

23. 'The verb 'to have' is rendered, as in Hausa, by the preposition 'with' = 'kě '; 'gworlong kĕ brüng-mă' = 'the king is with horses', i.e. 'the king has horses.' The use of ' do' in these phrases is inadmissible; one cannot say 'gwŏlŏng dō kě brüng' as the equivalent of 'the king is with horses.' (Note: this phrase must not be confounded with a similar sounding one, 'gwǒlŏng dō kă brüng'; for this 'kă' see chap. viii. para. 17).

24. The interrogative form is expressed by adding ' $\overline{\mathbf{a}}$ ?' with a raised questioning intonation at the end of the sentence.

'gŭrm jī' = 'the man came'; 'gŭrm ji $\overline{\mathbf{a}}$ ?' =' did the man come?'

25. If the last word in a sentence ends in ' $a$,' this ' $a$ ' 
is elided with the interrogative ' $\bar{a}$ ?' and becomes very lengthened.

'gworlơng kě brüng-mă' = 'the king has horses' ; 'gwơlơng kě brüng-mã ?' =' has the king horses ?'

26. Generally, but with a few exceptions which appear to be capricious, if there is a word in the sentence which is itself interrogatory, the ' $\bar{a}$ ?' becomes ' $\mathrm{e}$ ?' thus 'mě dō kwom kĕ lěŏk è ?' =' what is the news of the fight?' where ' mé ' = the interrogative 'what?' $=$ H. $m \bar{\imath}$ ?

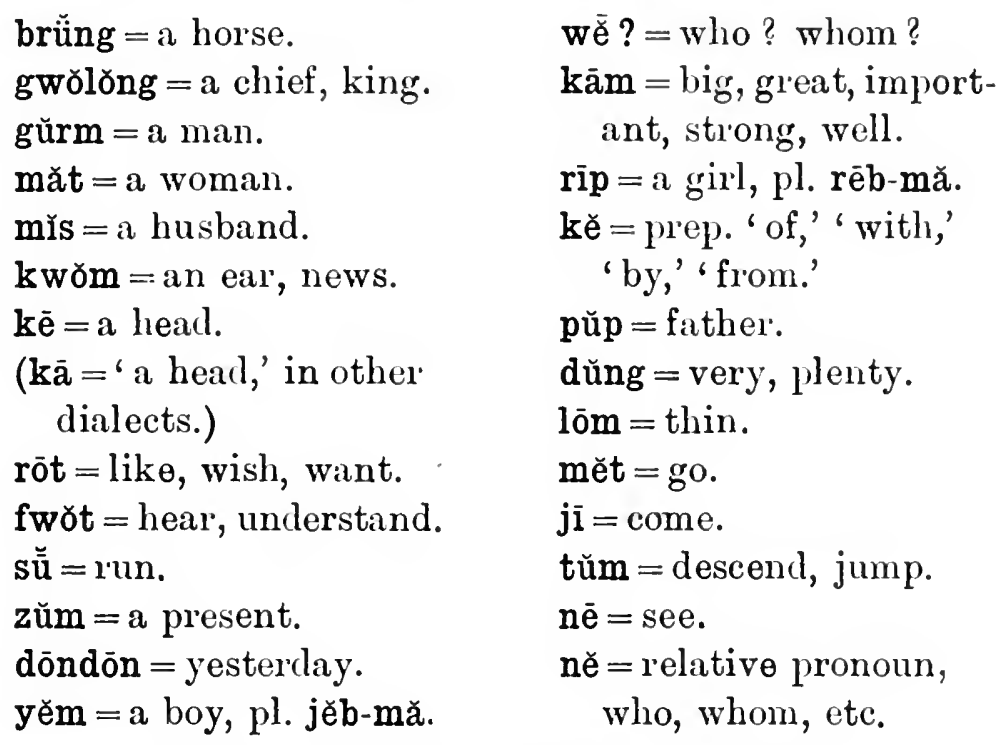

miss-kām =lit. ' the great husband,' or ' $\mathrm{man}^{\prime}$ ' =an elder' of a tribe ; sometimes found as 'dis-kām.'

(In the other dialects miss-kām $=\mathbf{g}$ worlong $=$ the king.)

a-fwơt à ? ăn-fwort; gŭrm tŭm kě brüng; jěb-mă mět; gürm rōt măt; ă-pǜn brüng gnăn; ğhā dō gwőlorng à ? gnăn nyī, or gnăn dō nyī, or gnăn gnět; pŭp kĕ jì kě zŭm; wē jī ? or wă jī ? rōt mē ? ă-jì kě rīp ně ăn-nē dōn-dōn. 


\section{CHAP'IER II}

1. The Demonstrative Pronouns are all suffixes.

'-nì' = 'this,' ' that,' both present and within reach.

'-pă'nă' = 'that' away over there, but in sight.

'-dă' = 'this,' 'that,' 'the,' referring to something alrealy mentioned or known, but not present (necessarily).

2. 'The plural forms are: '-nı̆'-mă,' '-pă'nă-mă,' '-dă-

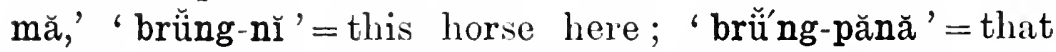
hor'se over there, pl. 'brǘng-ň̆-mă,' ' brüng-pă'nă-mă.'

'brǚng-dă' = the particular horse (we are talking of), pl. = brǘng-dă-mă.

3. '-nì' always refer's to something actually present, close, and visible, and is nearly always pointed at, or otherwise indicated by a jerk of the chin, or a pushing out of the lips, etc.

'-pănă' refer's to something at a distance, but in sight, and is inclicated by some gesture.

'-dă' refer's to something usually not actually present, but well known or understood, and answers to our 'the' (underlined or italicised) or 'the particular'; but it is at times even more definite, and becomes 'this' or 'that,' nearly. A safe rule is that our 'this,' 'that' should be translated by '-ň̆' or '-pănă' as the case may be; and wherever the sense will permit us to use 'the particular,' it should be translated by '-dă.'

' brüng-nì děl brüng-nı̆' = 'this hor'se (indicating it) is better than that one' (indicating the other), where both hor'ses liave been brought up and are standing close by.

' brǘng-pănă děl brüng-pănă ' = ' that horse (pointing to 
one $\frac{1}{4}$ mile off to the west) is better than that' (pointing to another 100 yards off to the north).

'ăn-rōt brǘng-dă ně ăn-nế dōn-dōn' = 'I like the (par'ticular) horse which I saw yesterday.'

4. The Relative Pronoun, 'who,' 'whom,' 'which,' is 'nè' for all genders and both numbers.

' mě' is sometimes heard, and 'dè' is also used in the hills.

(a) ' măt, nè mèt, bě $\mathrm{ji}$ ' = ' the woman, who went, has returned.'

(b) 'The woman, whom I sent, has run away' = ' măt, ně ăn-lěp, sū.' Note the following variations of $(b)$ -

i. măt dă, ně ăn-lěp, sū.

ii. măt, ně ăn-lěp, sū.

iii. măt, ně ăn-lěp nyi-dă, sū.

Of these (b), or i., according to the stress to be laid on ' the woman,' is best. The other two are admissible, but that is all. In ii. and iii., $c f$. with the Hausa mata, da na aike-ta, ta gumlu.

In the plural:

'măt-mă, ně an-lěp, mă $s \bar{u}$ ' = ' the women whom I sent have r'un away,' or 'măt, nĕ ăn-lěp mă, mă sŭ.'

This relative 'ně' may be omitted without injuring the serise.

5. The Interrogative Pronouns are-

'wē ?' sometimes 'wă ?'= who? whom?

'mè ?' = what? '-dăng ?'= which ? 'răng ?' or '-răng ?'

how? how much? how many?

'wē dō nyì ?' = who is this ?

'ă-rōt mè?' = what do you want?

'ă-gī wē?' = whom do you seek?

'brüng dăng tē ?' = which hor'se fell ?

'sǔm-fā răng e e ?' = what is your name?

'mă răng è ?' = liow many are they?

Note the similarity of wē? wã? and mē? to the corresponding Hausa words. Also the idioms in which 
'răng' and 'liaka' both meaning 'how' are used in such expressions as 'suncullia lickla ?' = 'sŭm-fā răng è ?'

6. 'The genitive is expressed by the use of the preposition 'kĕ' = 'of '; 'brüng kě gwŏlorng' = 'the horse of the king' ; 'brüng kĕ wē ?'= 'whose hor'se?' Very often an euphonic ' $-\mathrm{n}$ ' is inserterl after the 'kĕ,' thus 'brüng kĕ-n gwŏlŏng'; and the 'kè-n' partakes slightly of the sound represented by a short 'keün.'

This 'kè' = 'of' is the same as the 'kè' mentioned in chap. i. para. 15, meaning 'with.' This is important to note in view of what has to be said on the "continuous" tense (chap. vii. para. 8 , also para. 9 seq.).

7. This ' kè' $=$ 'of' is not always used to indicate the genitive (which, connoting possession, it is easy to understand as meaning both our 'of' and 'with'); but where stress is to be laid on the actual possessor, 'kě' would be used; brüng gwŏlŏng, by their juxtaposition, means 'the horse of the king.' Again 'gwŏlŏng brüng' or 'gwŏlŏng kĕ brüng' = 'the king of horses' or our 'horse king.' 'Gwŏlŏng Păng' = 'the king of Pang'; 'ār gwŏlŏng' = 'the king's path,' i.e. one leading to the king's house: 'ār kĕ gwŏlŏng' also means 'the path of the king,' but denotes some closer connection between the two, such as 'a private path.'

Again shăng = 'net' and bŭp = 'fish', shăng bŭp = 'fish net,' so also does shăng kĕ bŭp; but the latter has the meaning too of ' a net of fish' or ' a net for fish.' (Query, is there any distinction in Hausa between gidda-n bature and gilda na bature?) In fact, when the preposition is omitted, compare the phrase with such of ours as 'fish net,' 'house door,' etc.

8. 'This 'kĕ' in its meaning of 'with' is used like the Hausa ' $c l a$ ' to denote, to all intents and purposes, our 'and.' Thus-

gwŏlŏng kě mǐs-kấm-mă mă tŭm = seriki da serakuna sun sauke = 'the king and his officers have alighted.' 
9. The preposition ' kě ' does not correspond rigidly with our 'of' and 'with,' but has a subtler meaning, indicating a connection of some sort between the words which it joins (see chap. vii. para. 8).

10. The negative is expressed by placing ' $k \bar{a}$ ' $=$ ' not' $=$ Hausa ' $b a$,' at the end of the sentence; mă mert = they have gone; mă mèt kā =' they have not gone'; ăn-nè gurm $\mathbf{k a}=$ ='I do not see,' or', 'I have not seen, the man.'

11. The negative of the imperative, 'don't,' 'lest,' is expressed by either 'măn' or 'măntă' before the sentence, or ' $k a x t$ ' at the end, or' a combination of either of the first two with the last. Thus ' don't go ' = 'măn à-mět,' 'măntă ă-mèt,' or 'à-mèt kăt'; and also 'măn ă-mèt kăt' and 'mǎntă ă-mèt kăt.' The last two are more emphatic still than the first three. Of these last again the first two are stronger than the third, which is used somewhat deprecatively, as when inferiors address their superiors, 'ă-kăng mŭn kăt' = '(please) don't tie us together.'

12. The following variation is also used, 'măn ă-mět $\mathbf{k a}$ ' = the Hausa 'kadda ka taffi ba.'

13. This 'kat' is undoubtedly the origin of the Hausa kăddă. I quote the following from the Appendix II to the review on Mr. Ormsby's Angass Grammar I sent in to headquarters, 14th August 1909 :-' Angass words are mostly monosyllabic, ending generally in a consonant which is "closed." (The " $t$ " in our "pot" has two distinct sounds, the first when the tongue first strikes the roof of the mouth, and the second when it releases itself. On the other hand the " $t$ " in "pot-luck" has only the first sound and is consequently a "closed" "t." In the same way the "ck" in "black," which has the two sounds, is different from the "ck" in "black-guard" or "blackberry," when it has only one.)"

Owing to this it is sometimes diflicult to say if a ' $t$,' for instance, at the end of a word is a dull ' $t$,' or is more 
nearly a 'd,' but when it is followed by a vowel in the next word, its proper sound becomes more distinct, as in ' ă-pŭt à-mét.'

14. ' $\mathrm{dr}$ ' = the Hausa 'akwoi'= 'there is'; 'ámdí à?' $=$ 'is there water?' ' $d \check{r}$ '= 'there is.' The negative form 'dŕ-kă' is used like the Hausa 'babu,' 'ă'm-dí-kă' = ' rua balu' = 'rua ba alivoi ba' (one cannot say 'dr ăm kā'). 'ăm-dŕ-dă-dí-kă' is used by a man who happens to know that a spot, where water ought to be, and has been pointed out by another as containing water, as a matter of fact contains none and has dried up. These 'dr's' al'e not to be confused with each other, the second ' $d \check{I}$ ' $=$ ' $w u r i$ ' $=$ French 'chez,' thus ăm-dí-dă =rua(n) urìn and ăm-dí-dă $\mathrm{d} \check{\mathbf{l}}-\mathbf{k} \breve{\mathrm{a}}=\operatorname{rua}(n)$ wurin $b a b u=$ "the particular water (you mention) is not there.'

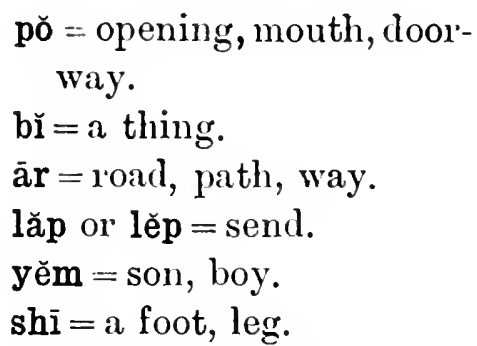

yěm-măt = daughter, girl.

$\overline{e r}=$ to scratch.

$\overline{\mathrm{gh}} \breve{\mathrm{u}}=$ goat.

ăm = water (drinking).

mā ( $t \breve{m} m$ in some dialects)

$=$ sheep.

kăng = tie, join.

fwăn $=$ (water in the form

of) rain.

pēt = five, 5 .

bĕ = return ; frequently

used with $\mathrm{j} \overline{\mathbf{1}}=$ to return

and come. lŭ = a but (part of a house $=$ our ' r'oom').

wŏk =a compound (composed of many lŭ-mă, or, huts).

lă = to take, seize.

$\mathrm{kwŏlm}=$ a lie.

' $-\mathrm{fa}$ ' = thy.

lă $\operatorname{shì~kè=take~the~foot~}$ of $=$ to follow, pursue.

chĕn $=$ to follow, nün, dün = inside, in.

$\bar{a}, \bar{a} \dot{n}, \bar{a} \dot{n} h a ̆=t h u s$.

nŭng = to burn.

tŏng = to sit, remain, be sufficient.

nŭng $=\mathrm{a}$ cow.

chăn $=$ to cut.

ch $\breve{\text { euk }}=$ to cut.

$\mathbf{k} \overline{\mathrm{e}}=$ head, on top, above. 
dār $=$ to stand, upright.

lěók = a fight.

kěsh $\breve{\text { euk }}=$ all, every.

ť̆ $=$ to fall.

lū $=$ to seek.

$\mathrm{l} \check{\mathrm{l}}=$ tell, explain.

măn, know, be able to. gð (in compounds, sometimes, gwó) = man.

mūt = to die.

sit $=$ to enter; also to barter, sell, buy.

lex $=$ to be ill; also to give birth, to beget.

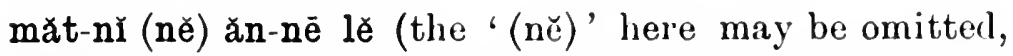
perhaps for euphony); măt-dă (ně) ăn-nē lě yěm; pŭp lě yěm-măt; brüng-dă, ně sū, mùt; mă sit dün lŭ; măntă à-ké brüng; wă-jī ? rōt mē ? nyī dō gŭrm ně ă-gī ; măt-nì yěm-măt kĕ gō-nĩ ; brüng kĕ wē sū ? ăn-măn kā; măntă yĩ chăn kwơlm; nyī dō wǒk kè pŭp kě-n gwơlŏng; mĕ do kworm kē lěók è ? gurm pēt mă mūt, măt mă sū kěshĕùk; mă nŭng wŏk kĕ-n gwǒlǒng kā; ă-lì nyī tě mē ? mā pēt mă sīt dǜn lù ; ă-ēr shī-fā kăt.

Note that chăn $\mathbf{k w}$ olm = to cut a lie, i.e. to tell a lie, as in Hausa, ' yenle liaria.' 


\section{CHAP'IER III}

1. The Indefinite Pronouns are:-

' -chĕ' = a certain (one), some (one) (m. and f.).

$\mathbf{k} \overline{0}-$ chè $=$ a certain one, some one.

$\mathrm{k} \overline{\mathrm{o}}-\mathrm{w} \overline{\mathrm{e}}=$ any one.

kō-mē = anything.

kō-dăng = which one.

kō-răng = how many? (ones)=also 'any how' = also 'any many' = H. lio-kiakia.

2. The plurals are formed by adding '-mă' ; măt-chè = a certain woman; măt-chĕ-mă = certain women.

Bring me the horses = ă-jī kě brüng-mă; which ones? $=\mathbf{k} \overline{0}$-dăng-mă è ?

Any ones =kō-wē-mă (of men); kō-răng (-mă), any many, any ones (of horses, etc.).

This (-mă) after kō-răng is better left out; mă kō-răng is also the answer.

3. Of these, only the first is a suffix; the rest, it will be observed, are formerl from the interrogative pronouns, by prefixing the particle ' kō', which is the same as is used in Hausa. This particle 'ko' plays an important part in the language, and should be noted as it occurs.

4. All these indefinite pronouns form almost an endless combination with each other, and also with the interrogative forms.

This will be dealt with in a separate chapter, but the following may be given as an example now (see chap. xiii.) : 
'măt-chě,' a certain woman, may be expressed by kō-mē măt dăng ; pār-chě = another (some) day ; pār-chě dăng = some other day.

5. brüng-dăng tē ? = which horse fell? Ans. kō-dăng tē, ăn-măn kā, or ăn-măn kō-dăng tē kā = I don't know which one fell.

br̃-chě $=$ 'a certain thing'; bř-chě dr̃-kã =' nothing'; 'gwǒ-chè kā' or dì-kā = 'no one.'

kō-mě (ně) ă-rōt ăn-pün ğhā = anything you want, I will give you; kō-wě (ně) kě jì ă-lě nyī ăn-mět = any one who comes, tell him I have gone (worls in brackets are

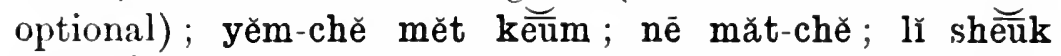
kŭrkūjí-chĕ nyī, 'a certain boy went to play; he saw a certain woman; he told her a certain fable.'

6. This same particle 'kó' (para. 3) prefixed to the suffixes of the demonstrative pronouns, renders the latter substantives; from '-nĭ' we get kō nì = ' this one,' '-pănă,'

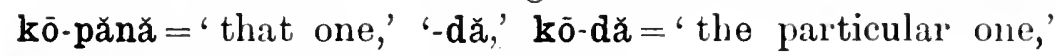
kō-pănă gū = 'that one yonder fell.'

(Of cour'se, though we can say brüng-pănă gũ, we cannot say kō-pănă brüng gū.)

kō-nì mět = this one went; kō-dă tē, kō-dă sù = the one fell, the other ran (off).

7. kōoni dĕl kō-nĭ=this one (here) is better than that one (here); kō-ní dĕl kō-pănă=this one (here) is better than that one (yonder).

8. ' $\mathrm{K} \bar{o}$,' again, can be prefixed to anything (a single word or a sentence) not a substantive, and thereby render it a substantive, e.g. găk = the numeral 'one' (1); brüng găk gu $=$ 'one pony fell,' kō-găk gu $=$ 'one fell,' nềt = 'reel,' kō-nět $=$ 'a red one,' ăn-rōt kō-net ='I want a red one,' ăn-rōt kō-nětt-dă = 'I want the red one'; nēr = 'midst,' kěnēr $=$ ' in the midst or' middle,' kō-kè-nēr, or' kō-nēr = ' the middle one,' 
mă tơng bāp = 'two stayed,' kō-mă tơng băp = 'those who stayed are two'; kō-mē kō-tr̆p = 'any' black one,' kō-mē kō-nĕt = any red one (see also chap. xv. para. 3).

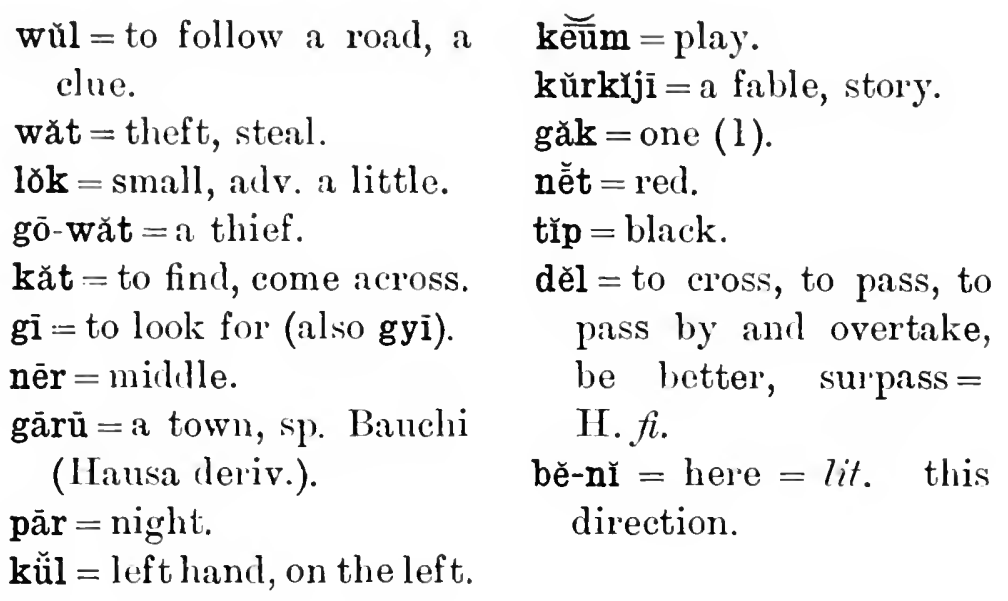

kō-wē kě jī bě-nĭ (n)pār, bě wăt = whoever comes her'e by night is stealing (the $(n)=$ euphonic) ('bĕ' is idiomatic).

ăn-rōt brüng-nì kà, ă-gi kō-chĕ gnăn = I don't like this horse, look for another for me.

ă-găm ār kō kĕ mĕt gārū gnăn =show me the road which goes to Bauchi, also = ă-găm ār, ně kĕ mĕt gārū gnăn.

ă-wŭl ār kü̆l=follow the left road.

ă-mět lok, ă-kăt kăng ār= when you have gone a little, you will find a junction.

ăn-wŭl kō-dăng è ? = which one shall I follow ?

kō kĕ nēr mĕt Kătāgŭm = the middle one goes to Katagum-(kō kĕ nēr should strictly be written kō-kĕnēr).

'The answer ' any one,' to ăn-wŭl kō-dăng ē ? 'which one shall I follow ?' may be kō-mĕ dăng='any one'; ă-wŭl kō-dăng, ă-wŭl dăng, or better, ă-wŭl dăng mă mă = H. 'lia bi liouani su su.'

Note.-Bĕ-nĭ comes to mean 'here,' but it is a noun, so too are 'nan' and 'chan' of Hausa; 'doli-n nan,' 


\section{GRAMMAR}

'aliwia-r nan' $=$ " the horse of this plice' = "this horse' and 'the goat of this place' = 'this goat.' The ' $r$ ' after 'akwia' shows it is the genitive, and therefore by analogy the ' $n$ ' after ' doli' is too; therefore 'nan' must be a noun. 


\section{CHAP'IER IV}

1. 'Ihe Angass, like most negroes, have a nice ear, and they endeavour to prevent hassh somds coming together. The chief method of doing so is hy inserting an euphonic ' $n$,' or else by leaving out the particular letter to which the difficulty is due. 'Thus rit yit = "pleasant to look at' = II. 'leau-n yani.' It, however', is quite hard to say, especially if it is rememberel that the ' $t$ 's' are 'closed' (chap. ii. para. 13). An Englishman would probably get orer the stumbling-block by saying ' rì tyitt, but this would convey nothing to an Angass, whose solution is rìtn yìt, or rìt nyìt, or rì yit (the last in this particular case is not used in practice).

2. Again, the 1st pers. sing. of the Personal Pronoun 'gnăn' often jar's, thus ă-lĕ gnan; this does not become 'ă-lĕg năn,' but 'ă-lěngăn.' These 'n' sounds are at fir'st frequently puzzling; as they are in the actual colloquial language, they are correct, and the strictly grammatical forms, as 'ă-lĕ́ gnăn,' are incorrect, and would not be unclerstood by the average man, unless, knowing one was a stranger, he took intelligent pains to try and gather what one was hiving at. It scarcely needs pointing out that in an unwritten language, whatever is said and understood generally by the people is the correct form, however much it may not fit in with rules deduced from the majority of similar forms. Thus we have 'ă-pün gnăn' = 'give me,' 'ă-mwăt gnăn ' = 'beat me,' 'ă-chăn gnăn' = ' follow me,' etc. ; therefore seemingly it ought to be 'ă-lĕ gnăn' = 'tell me,' but it is not-it is 'ă-lĕngăn,' and therefore 'ă-lěngăn' is correct ( $\overline{n g}$, nasal, as in 'hang '). 
3. In the same way rules are being evolved for Hitusa, which has not by any means a uniform standard yet. One in particular is being forced on stulents, viz., that nouns ending in ' $a$ ' are feminine. The exceptions, however, are so many, and so large a number even of those which the grammarians have settled as feminine are so frequently used as maseuline, that the learner gets puzzled, and appeals, probably, to a Mallam. He, however, is the last man to appeal to. He knows that theoretically there is such a rule, which also, as a matter of fact, is half natural to him owing to his knowledge of Arabic. The appeal should be to one who is not influenced by a foreign langnage, who can neither read nor write, but who c:m talk correctly. Of conrse, as the tendency of Hausa, owing to the Arabic influences, is towitds such a rule, and as it is already more than half establisherl, and as it will continue to be taught, it will in time become incorporated as a settled fact in the linguage, undoubtedly to its benefit. A consequence of this tendency and its influences is to react on corresponding parts of speech, and we get such forms as 'zuchia-tata' or' 'baliontakia-tata.' 'These forms, as education spreatds, will become the correct and only admissible ones; but all I am contending for is that they are due to outside influence and are foreign to the genius of the language, and that the original form wass 'zuchia nshi' - not even 'zurhian sa.' One of ten hears 'zuchian sa' and sometimes 'zuchian shi,' still: our grammarians unhesitatingly call them Provincialisms and even Barbarisms. That may be, but uneducated provincials do not invent phrases, nor are they responsible for the grammatical progress of their language. They are merely conservative, and retain the language as it has been handed down to them by their forefather's, and would continue to do so dill not writing and educationwhich among other things includes absorbing the experience of other's-indicate to them more facile forms 
of expression. But it is for this very reason that students of a language, so far from pooh-poohing provincialisms, should stuly them, for it is through them only-and especially is this the case in an mwritten languagethat we can get at what the original phrases were. Take, for instance, our word 'get.' Its past form is 'got' ; but in compounds we find 'forgot-ten,' 'begot-ten.' Why? Turn to the English of three hundred years ago, in Genesis, in Americanisms-which are the English of that period in many cases-and turn, too, to the countryside, where "provincialisms" still abound, and we shall find that 'gotten' was the original form. Even now 'gotten minerals' finds a place in the august language of Parliament. So far from contemning ' $z u c h i a n s h i$ ' as a barbarism, let us be duly grateful to it for having persisted to our time, and for having given us a chance of noting it.

4. In Angass there is no inflexion for gender. Beyond the 'vocative' forms of the personal pronoun, the pronominal prefix, and the possessive pronoun sing., there is nothing to show whether the subject or object is masculine or feminine (see too chap. xi. paras. 8 to 11 ).

5. 'Sheǔk' is the word for 'body' $(=$ H. jik $(k) i$, which is derived from it). It often becomes nearly 'shăk,' due to its proximity to other vowels, which makes 'shăk' easier to say.

6. From another word 'shăk' are formed the reciprocal pronouns.

'mŭ kör shăk,' or 'shǐ shăk,' or 'kè shăk' = 'we fight with one another.'

' mŭn shēr shăk $k \bar{a}$ ' = 'we are not friends with one another.'

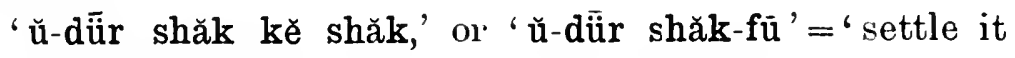
among yourselves.'

7. Note that 'sheuk' also means ' word,' 'speech.' In a sentence the context shows which meaning is to be under- 
stood, but when standing alone, and on other occasions, there might be ambiguity. 'Ihis, however, is obviated in practice by tacking on another word of a similar meaning. It will be noticed later, too, that the possessive pronouns have a contracted form. These contracted forms are always used for the word 'sheukn' ='a body', and the lengthened forms always with 'shēk,' 'a worll.' 'Thus 'shēuk-fănă' = ' my word,' 'shēuk-nă ' = 'my body.' But this is not possible in every case, as only five of the seven forms have contractions (see next para.). 'Then 'sheǔk,' 'a word,' is tacked on to some other word, e.g. ' tork,' which has a similar meaning. This method is resorted to very frequently, for in a monosyllabic language the variations which can be obtained with two or three letters are limited, and it of ten happens that the same combination of two or three letters means two or more different things.

8. The Possessive Pronouns consist of two sets: (1) The separable, (2) the inseparable. There is no difficulty in their use, as in Hausa, for there is no distinction or variation for gender.

9. The first set is as follows :-

$$
\begin{aligned}
& \text { mi - ná = mine } \quad \text { This mí- or mŭ- is } \\
& \mathrm{m} \check{\mathrm{I}}-\overline{\mathrm{g} h a}\left(\mathrm{f}_{\mathrm{f}}-\mathrm{y} \overline{\mathrm{i}}\right)=\text { thine } \\
& m \check{I}-\text { nyí }=\text { his, hers, its }
\end{aligned}
$$

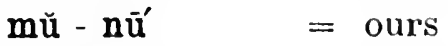

$$
\begin{aligned}
& m \breve{u}-w^{\prime} \quad=\text { yours } \\
& \mathrm{mu}-\mathrm{má}=\text { theirs }
\end{aligned}
$$

10. The second, or inseparable, together with its contracted forms, is shown under, with 'brüng ' = 'a horse.'

$$
\begin{aligned}
& \text { brüng - fănă contracted to - nă =my horse. }
\end{aligned}
$$

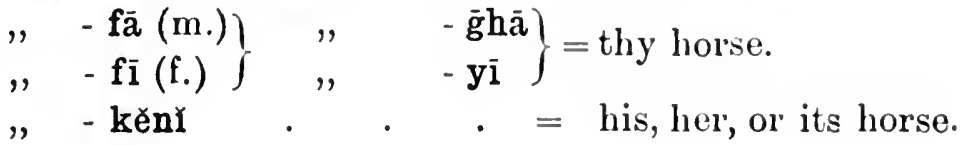




$$
\begin{array}{rlrl}
\text { brüng - fŭnū contracted to - nū } & =\text { our horse. } \\
,, \quad-\text { fū } & , \quad-w \bar{u} & =\text { your horse. } \\
,, \quad-\text { kĕmă } & . \quad . & =\text { their horse. }
\end{array}
$$

11. 'Though there are these alternative forms, it does not follow that either can be used indiscriminately with the sime word. Thus, though brüng has been taken as an example, one can only say brüng-fănă, never brüng-nă. Some words like brüng take only one form, and some the other, and some again both. I can find no clue as a gruile to their usage; it seems capricious.

12. 'Pŭp,' father', and 'nun,' mother, with these pronouns should be noted.

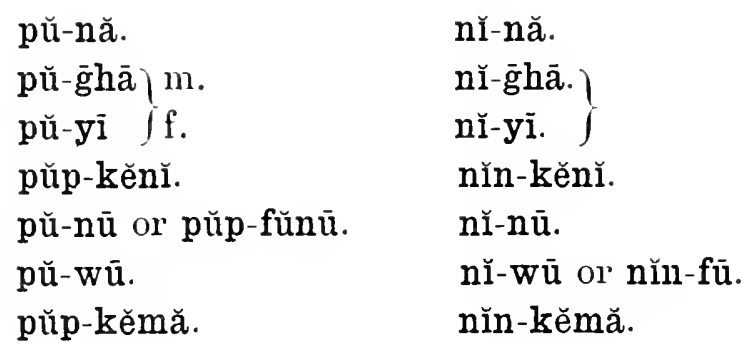

The lengthened for'ms are permissible too, 'pŭp-fănă,' ' nĭn-fănă,' etc., but the forms given are the best; 'pŭpnă,' too, is heard, but not 'nin-nă.' In the Hills ' nā-ù' = 'nĭ-nă,' where nā = 'nĭn'; 'ăpŭp' is also used for 'pŭp' in the Hills.

13. The plural is formed by adding '-mă' in the usual way : ' brüng-fănă-mă,' ' brüng-kĕmă-mă.'

14. What may look like a Possessive Pronoun is not necessarily one; e./. ' nyĩ kĕ bě kyăng yìt ghā' might be H. 'shizei lioma solie idonka' = 'it will return and pierce your eye,' but as a matter of fact the ' $\mathbf{g h a}$ ' here is the dative, H. măliă= 'shi zei loma soke maka $i l o$ ' = 'it will return and pierce to you the eye' ( $f f$. French, ' $i l$ vous percera l'ail'); 'your eye,' in this sentence would be, ' yĭt-fä.' 
15. The Reflexive Pronouns are formed by exactly the same idiom as in Hausa. 'Thus in IIausa ' lie kei ' = 'with head,' and in Angass it is 'shř kē,' where 'shř' = 'with' = II. ' la,' and $\mathrm{ke}=$ ' head' = II. 'laci.'

gnăn shĭ kē-nă (or'-fănă) = H. ni da lici-na= I myself.

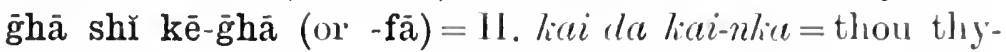
self (m.).

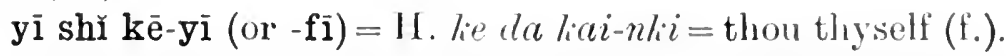

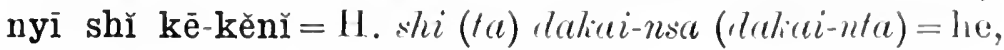
she, it; him-, her-, it-self.

mŭn shǐ kế-nū $\left(\right.$ or $^{\prime}-$ fŭnū $)=1$. mu da la selves.

wŭn shĭ kế-wū (or fü) $=$ H. liu da kai-nkiu = you yourselves.

mă shĭ ké-kĕmă $=$ H. su da kai-nsiu = they themselves.

'gwơlŏng shì kē-kĕnĭ mĕt' =' the king with his hearl went,' i.e. 'the king himself went.'

'măt-dă shĭ kế-kĕnĭ lěngăn' = 'the woman lierself told me.'

'mwăt kế-kěnī' = 'he beat himself,' or ' she beat her'self.'

'yĩ mět shǐ kế-yì' = 'go yourself' (f.).

16. 'gwǒlơng mă kě ăjiă mă pǒ lěǒk kĕ shĕuk veăng' = 'the ling and the Ajia are always fighting with each other.' Note the first 'mă';=H. 'serilii su da Ajia,' an idiomatic use of the plural.

'mă djū-mă, mă dūn ké̀ kĕmă' = 'they are stupids, they hur't themselves'; lit. they spoil their heads.

yǐt $=$ eye.

d $\ddot{u} r=$ arrange, settle.

rit $=$ good, pretty.

sheuk $=$ body, word, speech.

shēr $=$ friend.

nĭn $=$ mother.

kyăng = pierce (the eyo only). vǟng or vēăng (very long è)

$=$ always.

$\mathrm{dj} \overline{\mathrm{i}}=$ fool, stupill.

găk = one, only.

dūn = hur't, spoil, spoilt.

bāp = two.

dǒk = silence, keep sil-

ence. 
dăng = but.

pét-a pirticle, is some-

times $=11$. liuma.

por = the H. '-na,' in the

continuous tense, mu-na, etc. $\mathrm{kwān}=$ three.

shwār = laughter, laugh.

păk = some.....other's, re-

mainder $=$ H. saura.

găm = tell, explain, show.

' gwǒlŏng shēr-wū, ă-lě-nyī (ko) nyi dürr shěūk-dă wŭn' $=$ 'the king is your friend, tell him to settle the matter for your.'

'ăl-ă shī kě-n gơ-wăt, ă-jî́ bě-nĭ kĕ nyī', or 'ă-jī' kě nyī bě-nı̆' = 'follow the thief and bring him here.'

'yĕm mět keưm găk' = 'the boy went to play only.'

' mă kwān mă sīt dün lŭ, dăng ăn-kăt mă bāp găk' = ' three went into the house, but I found only two.'

' dün shē̌k kŭrkŭjī, nĕ mă lì(-n) shăk-dă, păk lě (or ' bī ') shwār dŭng, păk kĕ shwār kā' (or 'păk shăng shwār, păk shăng shwār kā') = 'among the stories which they tell each other, some raise laughter, others do not.'

' ă-dǒk mŭ-ğhā-dă'=lit. 'stop yours,' i.e. 'oh! stop your (story).'

'ă-găm mŭ-ḡhā mŭn pĕt ' = '(but) tell us yours.' 


\section{CHAP'TER V}

1. The Noun agent is expressed by the word ' $g 0{ }^{\prime}$ ' = ' $a$ man.' In composition it becomes shortened into ' $\mathrm{g} \delta$,' and often assumes a ' $w$,' ' $g$ wor.' Thus ' $w a ̆ t$ ' $=$ theft, to steal ; 'gr-wắt' = a thief ; 'lŏng' = 'goods,' 'possessions'; 'gwor-long' = 'an owner,', and from this, as being the great owner $=$ 'a king.' Its use is the same as the Hausa ' mai-' ; 'gwǒ-sit' = H. mai-chinilii=a trader ; 'gðð-wǒk' =

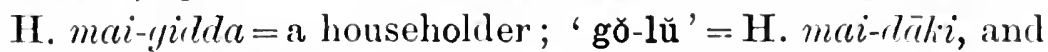
also H. mai-ungeca, or 'chief of a quarter' or 'suburb'; 'gס-yē-bŭp kè ăm' = H. mai-kaman-kiti-n rua = lit. a catcher of fish of the water, i.e. a fisherman.

2. The Hausa 'alinda' is expressed by 'bī-nè' = 'the thing which'; 'ă-găm bī nĕ ă-rōt gnăn' = 'show me the thing which you want'; ' bì ně ăn-nē' $=\mathrm{H}$. abinda na gani = the thing which I see, i.e. 'in my opinion.'

3. I strongly suspect that the Hausa ' $-d a$ ' which we translate 'who,' 'whom,' 'which,' etc., has its origin in the Angass '-dă' = 'the very,' 'the particular' (see chap. ii. paras. 1, 2, 3). Thus-

'brüng-dă, ně ăn-nē dōn-dōn, mūt' = ' the particular horse, which I saw yesterday, has died.' In Hausa this would be 'dolin da na ganshi jia, ya mutu,' which, literally translated, is 'the horse, which I saw him yesterday, has died.' The necessity of inserting 'shi,' ' him, ' appear's to show that ' $d a$,' 'which,' is not sufficient by itself, and is therefore not a true relative. 'T'iking ' $d a$ ' as being in origin the Angass '-dă,' we can translate ' the particular horse, I saw him yesterday, has died,' which conveys to 
us the same moming as 'the horse, which I saw yesterday, hats died.'

4. Aljectives, which are abundant, follow the noun they qualify. 'I'ley unlergo no inflexion whatever.

gō kŭn = a big. important man.

lŭ wărn =a big, large, spacious room.

măt rīt = a beautiful, goorl, pleasant woman.

brüng tĭp = a black, dark horse.

5. When necessilry, aljectives can also be formed from nouns, as in llausa, by the aid of the prepositions 'kĕ,' 'shı̆' = 'with' = H. 'dŭ.'

'shăng' = 'sweetness,' 'pleasure' = Hausa 'dālli,' 'shř shăng' or ' kĕ shăng ' = 'sweet,' 'pleanant' = H. ' ta dauli.'

'ār-nĭ kĕ jwāl dŭng' = H. 'hainya nan da eluchi dayauea' $=$ 'this road is very rocky.'

6. Our '-less,' as in 'shameless,' is translated simply by 'kāa' = 'not' or 'no'; 'bĕl' = 'sense,' 'cunning'; 'běl kā'= 'senseless' ; 'kēpăng'='shame,' 'kēpăng kā' = 'shameless'; 'kẻpăng nyì kà' ('nyī' is the dative) $=\mathrm{H}$. 'liumya yareshi ba'= 'he is shameless.'

7. The plural is formed by suffixing '-mă.' Thus ' brüng tĭp-mă' (note that 'brüing mă tı̣p' is 'the horses are black') = 'black hor'ses.'

8. Adjectives are formed into substantives by the prefix ' kō' (see chap. iii. paras. 3, 6, 8), 'nĕt' = red ; 'kō-nĕt'

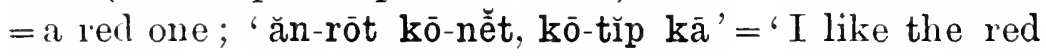
one, not the black one'; ' kō-rit $\mathrm{ji}$ ' $=$ ' the pretty one has come.'

9. Names for colours and expressions for shades of colour are numerous.

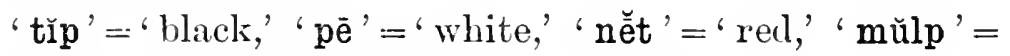
' green,' 'gŭım' = 'blue,' 'jăn' = 'yellow.'

A colour adjective reduplicated means a lighter' shade of that colour, 'nĕt nĕt' or' 'nĕ nĕt' = reddish or pink.

10. Various particles are in use to denote the shades, 
but, generally, each is confined to at particular colour', as

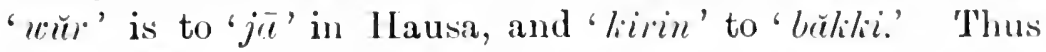
'nět găau' = very red ; 'nět kyăng kyăng,' 'nět kwǒk kwơk,' or ' nět păn pē pè' = redđlish, light red, pink (păn pē pē = partakes of whitish); nět fwŏlm fworlm = light piuk = just a touch of reel. 'Típ kŭm kŭm' and ' tǐp shǐ shìt (for shǐt shìt) = very black ; 'tǐp băng băng' = 'lighlit black,' or 'dark brown'; 'pē pǒk pǒk' = fari fet =ver'y white; 'pē vŭn vŭn' = whitish, with tinges of other colour's, as green, yellow, etc. 'Vŭn vŭn' is also used with 'nět'; nět vŭn vŭn = 'ver'y light red,' but not 'pink.'

Note.- 'Tĭp,' and the Ilausal 'baliki,' mean more 'dark,' in colour, rather than 'black,' and 'pē,' like the H. fari, is 'light' rather than 'white.' Objects are referred to as being 'dark' or 'light' irrespective of the actual tint. In Hausa, for example, navy blue serge cloth is called 'baliki,' and the light pink, say, of a flower, is spoken of as 'fari.' We are accustomed to translate 'balili' as black, and ' $f(u r i$ ' as white, but we camnot suppose that the Hausas really do not recognise the blue shade of the cloth, or the pink tint of the flower.

11. Colours are used in combination too; 'tĭp gŭlm gŭlm' ='black blue blue,' i.e. a dark violet; 'nět pē pē' $=$ 'a light red.'

12. 'mělp,' or ' mwělp' indicates a shiny, glazed surface, 'sheen,' 'glint,' etc.; ' tịp mělp săl săl' = verry black, with a sheen (as patent leather).

13. Among the Hill Angass, on the elge of the plateau, whose farms for the most part are on the plateau itself, there are numbers of ponies, for each difference of colour of which they have names:

'brüng fwălm' ('kăfălăk,' in the Hills) = a light bay.

'brüng kăleưng kăleüng' (also 'mōl,' in the Hills) = a bay with black points. 
'brüng vūn'

'brüng ès ğhrm'

· brüng răn gŭn răn gŭn',

A dark bay, and so on.

' chēwè' = black and white, black and tan, piebald, parti-coloured, etc.

' bì pè, dăp rāp' = a white thing, it takes dirt = a dirtyish white, as butter, cream, etc. ('dăp' or 'dăŭ (Hausa ' (lauka') = to take, lift).

' tịp dŭng $\mathbf{k a}$ ' = ' not very 'shǐkè shǐkế ' = H. dalıam black.' clabrm = different.

' kēpăng' = shame, modesty. ' jwāl' = stone, rock, rocky 'dăp' or ' düu' $=$ lift, take.

' kŭn' = great, important.

'wărn' = big, large.

'păn' = keep, to be like, partake of.

' $\mathrm{mwöl}$ ' $=$ brother, sister $=$ H. dan uwa. bill.

'běl ' = sense, intelligence. ' bŭn' = choose, select. 'kēn' = seed, species, kind $=$ H. $i v i$.

' băk' = short; 'dĭt' = short, small.

' chōr' = to annoy, poverty.

ă-jī kĕ brüng-mă gnăn, mă kēn shĭkē shūkē; ăn-rōt mă dŭng dŭng; ăn-bŭn kō-găk = bring me horses, different kinds; I want plenty; I will choose one.

kō ně ăn-rōt dĕl mă, nyī dō shěưk kăleūng kăleūng ; dăng fwit gnăn düng $\mathrm{ka}=$ the one which $\mathrm{I}$ like best of them, is the (body) bay with black points; but I don't mind much (it does not worry me much).

păk mă rit dŭng, dăng ăn-păn kŏ shěuk chēwē chēwē = some are very good, but I will keep the (body) piebald one.

brüng wărn rīt mwěn (or mět) lŭ jwāl-mă kā, mě kō băk băk-mă dăng = big horses are no good (to go) in stony places; only little ones.

('lǔ jwāl-ma' = 'a house of stones,' literally, and is an idiom for ' a stony place' in general) ('mě......dăng' = 'unless,' 'except' ; see chap. x. para. 22). 
gwollong sìt măt-ma pēt, (dăng) pün kō fīr (mă) mwơlkeny = the king has bought five women; but he has given four to his brother.

bī nè ă-rōt ann-măn kā; măntă a-chōr gnăn kă chōr chōr $=$ I don't know what you want; don't annoy me (annoying) (for kă chōr chōr = 'annoying,' see chap. viii. para. 16; also chap. $x$. para. 25).

go lŭ chēuk măt kŭn; rōt nyī kā, sẹ̌ kō lă kè shī = the householder beats his head wife; he loes not like her, only the one after her (i.e. the next, or second, one). 


\section{CHAP'IER VI}

\section{THE VERB}

1. Before discussing the Verb, as such, it will probably simplify matters, if the following remarks are considered first, not by any means as axioms, but merely as facilitating the notices on the verb.

2. In all probalility, then, there are no verbs in Angass, in our sense of the term. All words which at first sight appear verbs are really substantives, which take on the nature of verbs by the use of certain forms, the pronominal prefixes, set apart for the purpose.

We have an analogy in English, viz. 'To Boycott,' ' $\mathrm{He}$ out-Herorler Herod.' Again, words like 'horse,' 'rat,' 'shadow' were substantives long before they were used as verbs, e.g. 'He horsed his men from the neighbouring farms,' 'He ratterl at the last moment,' 'See, he is shadowing the woman in red,' and so on. The above have become recognised in this connection by usage; but we can still take any noun, which we may never have employed in this manner, and, by tacking on the established verbal inflexions, we shall be perfectly understood. Thus, take 'gliost' and 'football'; 'I peeped round the corner at mirdnight, and saw her ghosting down the corridor.' 'What wretches! they footballed a puppy the whole length of the road.' 'The English may not be good, but the meaning cannot be misunderstood.

3. As a language gets elaborated, words get segregated into 'parts of speech'; thus 'build,' 'ask,' 'carry,' are verbs and not nouns. Hausa is emerging from the stage 
of 'all nouns,' as is shown by the inflexions, among other' things, for the verbal noun, active and passive. But for some part, it is still in the more primitive stage, and the acceptation of this would make the language easier for the beginner to grasp. 'Thus the H. 'berri $i$ '= "sleep,' a noun, but the employment with it of the established pronominal prefixes shows that it is being verberl (an example to illustrate my meaning!), and so we get 'sun berchi,' 'sulk berchi,' ete., where 'berchi' is a verb. 'Berchia,' the verbal noun, is yet to come.

4. In Angass any noun can be tacked on to these prefixes, to turn it into a verb, e.\%. 'kē' = 'a heal,' and so anything 'on top', and then 'up above.' 'Ăn-kē '= 'I upped above,' that is, 'I mounted,' or' 'I climberl' (see also ehap. $x$. para. 1, last sentence).

5. To return to the orthodox view, the verb undergoes no inflexion of its root for tense or person. This is remarkable, and has its analogy in Hausa. Further, it has no change for any forms whatever, such as for verbal nouns.

6. Again, like IIausa, one form of what is called the personal pronoun (but which I prefer to eall the pronominal prefix or the pronominal inflexion) does duty as a rule for all the tenses. The context refers the time to the past, present, or future (see Viller, Hausc Notos, 1. 43 , Note N.r.).

7. These prefixes have already been given in chalp. i. para. 6, and are repeated here:-

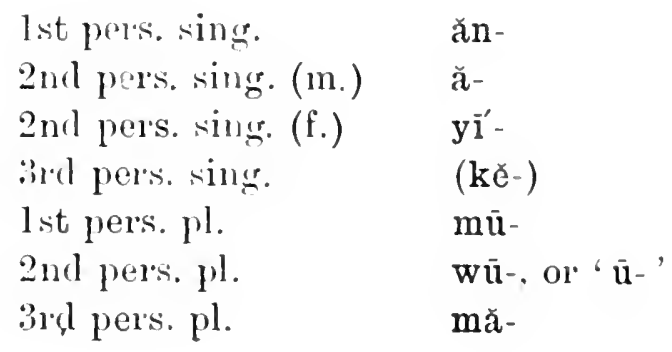


8. Can these be regarded as inflexional prefixes? or are they merely (as stated in Robinson's (irammar on the analogous Hausa forms) another form of the personal pronoun? The construction being the same in both languages, whichever they are in the one, that they are in the other (see chap. i. para. 6).

9. It will be noticed that in the $3 r$ d pers. sing. the (kě-) is placed in brackets; for two reasons, namely, first, that in all the past tenses, such as 'has given' or 'gave' the ' $k e$-' is not used, as the root of the verb is itself the $3 \mathrm{rd}$ pers. sing. of the past tense; thus 'pün' = ' he gave,' or ' he has given,' 'mět ' = 'he went,' or 'he has gone'; and secondly, because I think that the 'kè' is in origin the preposition = 'with'; thus ' kě pün' = 'gives,' or '(he) will give,' but most probably, if not almost certainly, its literal translation is 'with giving'; thus ' nyi kě pün' = 'he with giving,' i.e. 'he gives,' and also, according to the context, ' he with giving (to-morrow)' = 'he will give.'

10. The person being so definitely ascertained by these prefixes, a nominative is not always necessary; thus 'ă-pün' = 'givest,' ' wilt give,' 'gavest,' ' hast given,' and very frequently 'hadst given.' Consequently there is no necessity for the 'thou' which we are accustomed to, except for emphasis, e.g. ' $g$ hà ă-pün' = 'thou, thon hast given' = H. kai ka bia. The 1 st and 2nd pers. need no subject, as the person is sufficiently indicated by these prefixes, but the 3rd pers. must have a subject, unless it is made clear by the preceding conversation, as it can refer to everything or everybody in the world except the speaker and listener. Thus 'mět à ?'= ' has he, she, it gone?' 'mět' = 'he, she, it has gone,' 'kě mět' = 'he, she, it goes,' or 'will go'; but, 'mă mĕt à ?' = ' have they gone?' 'gŭrm mět, dăng măt mět kā' = 'the man has gone, but the woman has not gone.' 
11. ăn-pün brüng nyī, yī sār mă sīt=I gave him a horse ten year's ago.

li tě ăn-pün brǘng nyi $k \bar{a}=$ he said that I did not give (or have not given) him a horse.

ăn-pün brǘng nyī dì- $\overline{d h e ̄ r}=I$ will give him a horse to-morrow.

ăn-pün brüng (bě) dǐskăm-mă găk =I give horses to important men only.

kě lí tề ăn-pün brüng nyi kā = he says I have not given him a horse.

12. Nite the 'tĕ' after 'lĭ'; it corresponds to our' 'that' after words ' to say' (that), 'think' (that), etc., but it is more definite and is more nearly equivalent to our 'viz.,' or 'i.e.'; thus 'li tê '= 'he sail, viz.-' or 'he sail, that is-' or' 'that is to say-'. This 'tĕ' may be the origin of the ' $t \check{a}$ ' in the Hausa idiom ' mu zo tă berrhi' = 'Come, that is to say, to sleep.'

13. 'găt' is very nearly the same, in usage, as the Hausa 'Kiŭn'; thus, 'kắrăng-mă, gắt mă chin yĭn păs shř kónkworní' = 'the Angass are in the hallit of making arrow poison fr'om the strophanthus'; 'găt mă chǐn ànhā' $=H$. su lian yi halila $=$ "thus they an e in the habit of doing.'

' chin' $=$ to do, make $=$ the Hausa ' $y i$ ' in all its uses idiomatic or' otherwise.

'yĭn' = medicine, poison.

'kwornkornī' = the Hausa 'liontioni' = the strophanthus; in the Hills it is 'dìmók.' 'păs' = an arrow.

$k \overline{\overline{e u}} t=$ to finish.

pŭs $=$ shoot.

shĭt $=$ work, grass, bushcountry.

púd 1 = day af ter to-morrow. $\mathrm{p} \overline{\mathrm{i}}=$ on account of .

pì-mè $=$ why ?

mă pŭs nyī shř (or kě) păs ; mūt kā, dăng kě mūt = they have shot him with an arrow; he has not died, but he will die, literally, but (he) with dying. 


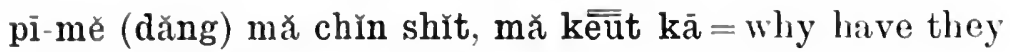
not lone this work and finished?

pŭdì mă keut = to-molrow they will finish.

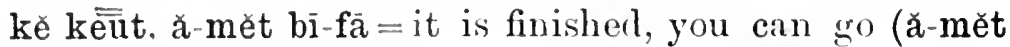
bì-fà = H. liu tenfi abinlia $)$.

ăn-pün bì zŭm nyī kā, chĭn shĭt kā=I have not given (or, will not give) him a present; he has not done the work (bì zŭm = H. abin lieauta).

gŏ-wăt-chĕ, tě Dēshĕưk, chĭn wăt-nŭ=a certain thief, that is to say Děshĕk, has done this theft. (The 'tě' here corresponds to the Hausa ' wei' or' ' Meishi.' There is a Hausa word ' $\overline{a \imath}$ ' = 'i.e.' or ' $v i$.' Is ' $w e i$ ' a vulgarised for'm of this' ' $\overline{a l}$ '?) 'Tě' and 'lì tě' are both used, like the Hausa ' "rei,' by an interpreter', or' any one else, to introduce a question or speech spoken by some one else.

To summarise :-

ăn-pün = I give, shall give, have given, gave (had given). ă-pün = thou (m.) givest, shalt give, hast given, gavest (hadst given).

yī-pün = thou (f.) givest, shalt give, hast given, gavest (hadst given).

kě-pün = he gives, will give.

- pün = (he) has given, gave (had given).

mŭ-pün = we give, shall give, have given, gave (had given).

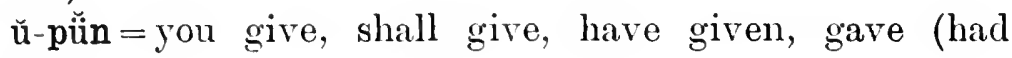
given).

mă-pün = they give, shall give, have given, gave (had given).

It will be noticed that the tense 'had given' is placed in brackets; the forms given above do have this meaning, but there is a special form (chap. viii. para. 5) for 'had given' which is noticed under the 'narrative tense.' 


\section{CHAP'IER VII}

\section{THE "CON'TINUOUS" TENSE}

1. In Hausa we have the "Continuous" tense, a form so remarkable as at once to arrest attention. In Angass there is a precisely similar construction. As it has not been gone into by anyone else, I renture to give an explanation, taking first the Hausa forms as being intelligible to everyone. I have alrealy done this twicein December 1907, in my Notes on Hausa; and again in August 1909, in the Appendix II to my review on $\mathrm{Mr}$. Ormsby's Angass Grammar; but as this grammar is it; natural setting, I need not apologise for going over the explanation again.

2. 'Iake the Hausa sentence, 'suna tinsa' = 'they are following him.' Rewrite it thus, 'su-na li-nsa', and leave it for the present, merely asking ourselves what is the '-nc,' and what is the '-nsc,' and what is ' li '?

We have (still in Hausa) :-

3. mu-nu taffia = we are going.

mu-na liomowa = we are coming, returning.

mu-na liavoura = we are bringing.

su-na lafia $=$ they are well.

su-na chäch $\bar{a}=$ they are playing ' chacha.'

We see in these expressions that ' -na' is followed always by a substantive, the first three being verbal nouns. In some Hausa verbs, the verbal noun has no form different from the root itself, thus 'aili $i$ ' = 'work' and 'working,' 'bi' ='follow' and 'following'; thus when 
we see 'sunc ailit' ol 'sunu hi,' we know from the analogy' of the above five examples that 'ailit' and ' $7, i$ ' ar'e on these occasions rerbal nouns. That being so, what is the '-na'? Evidently it must be something capable of soverning a noun, or, at any rate, capable of joining a pronoun to a noun. It camnot be an anxiliary verb, as thit would require either a participle or an aljective after it; and even if the rerbal noun formation could by any chance be considered as showing a tendency to a participial significance (as in 'yce tafji licuronce' = 'he has sone fetching' (?)), 'lafia' and 'charha' cannot be so regarded. Nor are they arljectives. Consequently it must be a preposition, or a transitive verb with some signification such as 'have.' 'There are no difficulties in accepting it as a preposition, but there are if we regird it as a verb. In the first place, any such word as 'to have' is so important a step in a language that we should be bound to come across it in other constructions, but there is no trace of it either in form or structure. Secondly, the '- na' form refer's to past, present, and future. The Hausas have tenses, but there is no variation of form with '-na' to show the tense. If ' $-n a$ ' is a verb, our' original sentence must be capable of meaning ' $I$ am having, the following (or the pursuit) of the seriki,' ' I was having,' 'I shall be having,' 'I had been having,' for 'ina lin serilit' commotes all these meanings; but in a language where there are distinctions for tense, it is difficult to imagine one form of a verb on this occasion only doing duty for all these tenses.

4. On the other hand there is no difficulty in accepting '-na' as a preposition with some meaning akin to our 'with'; not the 'with' denoting possession as in 'I will come with it,' but a 'with' denoting a much vaguer connection, more like 'I will come with pleasure.' Moreover, we already recognise a preposition ' $n a$,' denoting comnection, which we translate 'of', and it is not a far 
cry to assign to it a meaning the connection ' with.' We have seen (chap. i. para. 15, and chap. ii. paras. 6, 7, 8, and 9) that in Angasss there is such a preposition 'kě' having the two meanings. 'Taking ' $n a$ ' then, as a preposition, we get 'min-na lafia' =' 'we with health,' and 'mu-na taffia' =' we with going'; the context will show when we are with the going, thus-

ma-na tafjia = we with going = we are going;

jia muna taffia = yesterday we with going, i.e. we were groing yesterday;

sheliara yoma yana taffia har ulunsa ya hannoshi= ten years he with going until his father stopped him (Robinson), i.e. he had been going ten years until his father stopped him;

muna auc gobe $=$ we with coming to-morrow, i.e. tomorrow we shall come.

5. We have explained what '-na' and ' $b i$ ' are in our' original sentence. There still remains '-nsa.' Robinson says that with the forms in '-na' a "connective ' $n$ ' is placed between a verb and its subject." But why should the forms in ' $n a$ ' only have this connective ' $n$ '? This in itself shows that the constraction is different. We have 'suna bin serilii,' but 'su bi seriki,' 'sun li serilii,' 'sulia bi serilit.' Again, if the ' $n$ ' is only connective, why is it 'bi-nsa' and not 'bi-nshi'? It is 'sulia, sun, su biski.' The last three are recognised as tense formations of the verb; 'suna bi-n seriki,' then, follows a different construction altogether.

6. '-nsa' in itself suggests the inseparable form of the possessive pronom, and, knowing that ' $l i$ ' is the verhal noun, we can see that 'bi-nsa' means ' his following' and ' lin seriti' = "the following (or pursuing of the seriki.' The ' $n$ ' then is not merely a connective ' $n$,' but is the contracted form of the genitival preposition ' $n a$ ' $=$ ' of,' and our sentence becomes clearly, 'we with his pursuing' 
= 'we are pursuing him 'or 'we were' or 'had been,' etc., 'pursuing him,' according to the context.

7. '-na' then is a preposition. Not having a similar idiom, we have not a word to translate it precisely, but our 'with' is the nearest we can get. 'The ' $-n$ ' is also a preposition, and, as it denotes the genitive, it can be translated in a manner parallel with our 'of.' 'That these two were originally the same word, too, aclmits of no loubt, I think.

8. In Angass the form of this construction is-

gnăn kĕ $\quad$ rōt $\quad$ kĕ ăm, which equals the
Hausa $i-n a \quad$ so $-n$ rua
$=$ I with want(ing) of water.

' rōt kĕ am ' = 'wanting of water,' and ' rōt' = 'wanting,' 'kĕ' = the preposition 'of,' and 'ăm' is 'water', 'gnăn kĕ' = ' $I$ with'; and in this sentence we see the preposition ' kě' exhibiting its two shades of meanings; just as ' $n a$ ' does in the Hausa one. If we translated it 'I with want with water,' it would be still intelligible; but English has got beyond the primitive stage of the Angass, where one word has shades of meaning to be determined only by the context.

9. Though this sentence, 'gnăn kě rōt kĕ ăm,' is perfectly grammatical in structure and is intelligible, nevertheless it is not 'gurmă' or idiomatic, and the Angass prefer an idiom whenever possible. 'This particular 'tense' takes the idiomatic form of 'gnăn pŏ rōt kĕ ăm'; but the usual form still in the Hill Angass is 'gnăn kě rōt kě ăm.'

10. This tense is more limited in its meaning than the Hausa for'm in '-na', and denotes actual uncompleted or continuous action, at the time of speaking. In English we have two forms of the present tense, thus: 'we do the work,' and 'we are doing the work.' In Angass, too, 
we have two forms, 'mŭ chĭn shrt,' which corresponds with 'we do the work,' and 'mŭn por chĭn kĕ shĭt' = 'we are doing the work.' Hausa has only one form for the two $=$ ' mu-na yi-n aiki.'

11. 'This 'po' form denotes actual action at the time of speaking. For instance, if an oflicial had left his oflice and hat gone home, and some one were to saly of him, "he is busy on a murler case," the "po' form would not be used; but if he were in his office, actually trying the case, then "he is busy on a murler case" would be fitly translated by the 'po' construction. 'Thus-

ăn rōt ăm = I want water (but later will do).

gnăn po rōt kĕ ăm=I am (actually) wanting water (now).

mă yĕ ku lŭ shř wăn = they make houses with mud (clay). mă pǒ yeưk kě lŭ shĭ wăn=they are (now, at the present moment) making houses with mud.

12. This word 'pŏ' = 'mouth'; and even in this isliomatic use we can trace a similax idiom in Hausa, where 'baki,' 'a mouth,' is employed to denote being in the act of doing a thing, e.!. 'su balii-n zua ne' =' they are in the act, or' point, of coming'; 'su balii-n liarowa-r doli ne'= 'they are in the act of bringing horses'; but whereas in Angass' 'po' has come to be of every day usage, in Hallsa 'balii' is confined to a particular point, and has, for the tense given way to the vaguer ' na.'

13. The full tense is:-

\begin{tabular}{|c|c|c|c|c|c|}
\hline ğhā & pǒ & , & kĕ & , & (III.). \\
\hline y' & pǒ & , & kë & , & (f.). \\
\hline- & pŏ & ", & kĕ & ", & $\begin{array}{l}\text { ("nyī' may be inserterl for" } \\
\text { emphasis). }\end{array}$ \\
\hline mŭn & pó & ," & kë & ," & \\
\hline wŭn & pŏ & , & kĕ & , & \\
\hline mă & pঠ & , , & kë & , & \\
\hline
\end{tabular}


14. 'The preposition ' kè' is sometimes omitted, but the best form is to put it in.

$$
\begin{aligned}
& \mathrm{m} \overline{\mathbf{l}}=\text { to rouse, to cause to } \quad \text { rŭ }=\text { reach, arrive at. } \\
& \text { wake up. yēng }=\text { on top, the encl. } \\
& \text { sēm = sleep. } \quad \cdot d \bar{o}=\mathbf{a} \text { shout, yell, scream. } \\
& \text { kăt = olıtain, fincl. wāl }=c r y \text {, sol. } \\
& \text { năng = call. tăp=look after, care for. } \\
& \text { mwèn, another form for } \text { wŭs }=\text { fire. } \\
& \text { 'mět' = to go. }
\end{aligned}
$$

ăn-mī mă kä, mă pǒ sēm = I will not rouse them, they are sleeping.

ă-kăt mă pǒ shĭt chĭn kā, bĕ ă-năng mă = if you do not find them at work, call them ('bè' in the second sentence connotes our 'if' of the first; shit or' shit chin = work; see chap. ix. para. 5).

fwăn pǒ tě ; chōr yı̆t-nă; gnăn pǒ rōt kĕ mwĕn = raiu is falling; it annoys me (my eye); I want to go.

mă pǒ kē à? mă (kĕ) rŭ kĕ yēng ā ?=are they (still) climbing? (or) have they reached the top?

wŭs pŏ nŭng kĕ-nĭ ; ăn-chĭn răng ē ?= the fire is burning it; what shall I do?

ăn-fwŏt jĕb mă pŏ $\cdot d \bar{o}=I$ hear the boys shouting (·dō also = the war-cry or 'Tiururua'; a very peculiar ' dd, pronounced almost as if one were first holding one's breath; there is a similar ' b' too, p. 99, para. 14).

măn chōr ḡhā kā; gnăn pǒ tăp kĕ chĭ́n-fā kěshěũk = don't worry; I am looking after all your work (or business).

As an example of alternative and idiomatic phrasing, the last sentence would be better thus: măn chōr ḡhā kā; gnăn pŏ tăp-fā kěsheūk chín-fā. 


\section{CHAP'IER VIII}

1. The Future simple is the simple form as already shown in chap. vi., with the ordinary pronominal prefix, the context determining the exact tense.

2. The Definite Future, ' $[$ am going to,' is formed in the same way as in English and Hatusa, by the aid of the verb ' to go' = mert in Angass.

ăn-mět pün $=I$ am going to give.

ă-mèt pün = thou (m.) art going to give.

etc. etc. etc.

3. In this tense, the verb following the auxiliary 'mèt' appear's to be of the verbal noun form, for it takes the preposition ' kěe,' 'of,' after it-e.!/ :

ăn-mět pün kě brüng nyi $=[$ am going to give him a hor'se, lit. 'I go giving of a hor'se to him.'

mă pó mět kě pün kě brüng nyi = they are (in the act of) going to give him a horse, i.e. lit., "they are going of (or, with) giving of a horse to him.'

4. Verbs taking two objects, one in the accusative and the other in the dative, are followed first by the accusative, and later by the dative, which is generally put at the very end of the sentence, e.\% ă-găm ār gnăn, ner kè mět gārū = "show me the road which goes to Banchi'; a better way still is-ă-găm ār, ně (or kō) kè mět gārū gnăn.

5. A "Narrative Past" tense is formel by prefixing ' kă' to the verb, thus :-

ăn-kă-pün = I had given (and sometimes) I gave.

à-kă-pün 
- kà-pün = he had given (and sometimes) he gave.

mŭ-kä-pün

ù-kă-pün

mă-kă-pün

Nite.-It should be noter that although numbers of Angasis recognise this 'kă' for'm, there are also number's who rlo not. If it is a tense inflexion it destroys the symmetry which recognises only one tense formation for all the tenses (see chap. vi. para. 6).

'This ' kă' is enunciated with a rery short 'ă,' and as part of the verb, and not as part of the pronominal prefix as in the Hausa 'sulic bia.' 'The 'kă' is so short, in fact, that some might feel inclined to write ' kě' ; but, on the whole, I consider ' $k a ̆$ ' as more nearly representing the actual sound, and also it prevents its being mistaken for the preposition 'ké.' That it is not the preposition is clear from the form of the pronoun; for, if it were the preposition, it would have to be 'gnăn kĕ-pün,' ' mŭn kĕ-pün,' etc.

'Befor'e he died' = dŏk-dă bē kă-mút kā=lit., ' formerly when he had not died.'

'Before we came' = kă-pī-dōn mŭ-kă-jī kā = 'since we had not come' (kă-pī-dōn = Hausa 'tunda').

6. The Imperative is of the same form as the rest of the verbal forms, only uttered with the necessary tone of autbority.

ă-pün, or pǜn = give, or give thon (yi-püin, f.).

pün

mŭ-pün = etc.

$\breve{\text { u}}-\mathrm{p} \breve{\mathrm{n}}$

mă-pün

ă-pün (or pün) brüng nyī = give him the hor'se.

7. The negative of the Imperative has already been dealt with (chap. ii. paras. 11, 12, and 13), e.g.:

'măntă ă-pün,' 'măn mŭ-pün,' 'mă-pün kăt.' 
8. 'Let' is also expressed by the verb ' $y$ yit' = ' to allow,' in the same way as with 'beri' in Hausa.

yrut mă-pün or yìt mă mă-pün = let them give. ă-y̌rt mă-pün or ă-yĭt ma mă-pün = let them give.

And still another form (ă)y̌rt(mă) kō mă-pün, where ' kỏ mă pün' is the subjunctive $=H$. 'don su lia,' that they maly give.

9. The Subjunctive is formed by plateing the ubiquitous particle ' $k \bar{o}$ ' before the tense:

kō ăn-pün

kō ă-pün

kō nyī pün (=H. lon shi bia)

etc.

etc.
$=$ that I may or might give. etc.

etc.

10. These are frequently contracted to:

kwăn-pün.

kwă-pün (kō yī-pün, f.).

kō nyi-pün, also kō pün.

kō mŭ-pün.

kū-pün.

kō mă-pün.

'Fill my water-bottle that I may go to work' = ă-găm bēng ăm gnăn, kwăn-mět shĭt-chĭn.

'This ' ko' of the Subjunctive is posisilly only the ' kō', meaning 'like,' see chap. xv. para. 1 ; and the Coast 'pidgin' English may give us a clue; thus, 'give me water, like I go'='give me water, that I may go.'

11. If we assume that Angitss has verls proper, then it also has verbal nouns, which are identical in form with the root of the verb itself, and which do not vary at all, as in some cases in Hausa. If, however, there are no verbs (see paras. 1-4, chap. vi.), then what might be 
supposed to be verbal nouns are, of course, merely substantives, thus-

pün kĕ brüng kīmì shèr = eithel',

'The giving of a horse is a sign of friendship,' or'

'The gift of a horse is a sign of friendship.'

The sentence can also be put:

pün brüng kīmī shēr-(kīmī = evidence, shēr = fr'iend $)$

His rumgin! allay wass no one's fault = bār-kěnĭ shĕ kŭk măng kĕ gwŏ-chĕ kā.

12. The Infinitive. Taking this under the three following headings, we find :-

(i.) To give is troublesome = pün lē kē, or pün pŏshĕ

(ii.) I wish to go =ăn-rōt kwăn-mĕt.

(iii.) Tle brought food to eat = jī kĕ bī-sě kō nyī sě.

It will be seen that (i.) is a verbal nom, and (ii.) and (iii.) are the subjunctive.

These are the only two ways of translating our infinitive. There are, of course, periphrases, as in Hausa, such as utilising the future (see examples below), or some word like 'on account of,' ' in order to' $=\mathrm{H}$. garin $=\mathbf{p i}$ in Angass, etc.

Thus, ' I am preparing to travel' = gnăn po deur kěsh ̌ư kwăn-mĕt (subj.) (or pi mĕt $=$ H. garin taffia).

'I shall try to come back' = ăn-dār kwăn-bē (subj.) or' ăn-dār bē (verbal noun), lit. 'I shall try that I may return,' or, 'I shall try returning.'

'I sent a man to bring the horse' = ăn-lěp gō kō nyī jī kě brüng (subj.), or ăn-lěp gō ně kě jī kë brüng (fut.= 'who will come with the horse').

'There is nothing for me to eat' = bi ăn-sě (fut.), or kwăn-sě (subj.) dìkā = 'the thing I shall [or I may] eat, is not.'

'I taught him how țo clean his hor'se' = ăn-găm văng kĕ 
brüng nyi (verbal noun, i.e. "I showed the cleaning of the hor'se to him').

'I sent him to bring the horse' = ăn-lěp nyì (tě) kō nyī jī kě brüng (subj.), or ăn-lěp nyĩ pĩ jī kě brüng (verbal noun; $\mathbf{p} \overline{\mathbf{i}}=$ Hatusa garin = !farin zuc cla doli, i.e. 'for the sake of coming with the horse').

'He went to seek the horse' = mět kě gì kě brüng, or' mèt gi kě brüng (verbal noun), or mèt pī gī kě brüng.

13. The Pasive.-There is no separate form for the passive. All that we express by the passive is rendered by the use of the impersonal pronoun 'mă' 'they;' or' 'one,' or 'people' (see chap. i. para. 14). This is exactly equivalent to the impersonal pronom ' $a$ ' in Hansa, e.g. 'su-n bani Tiurdi' = 'they have given me money', ' $(-n b a n i$ liardi' = 'one has given me money' = "I have been given money,' 'mu-ka ta!jie'="we went,' ' $a$-ka tatji'=" people went,' "lia liamashi' = 'catch thou him,' " kiamashi'= 'let people catch him' = 'let him be caught.'

14. Thus in Angass mă mwăt gnăn= either', 'they beat me,' in which case some particular per'sons have already been referred to before, or else the impersonal, 'people have beaten me,' i.e. 'I have been beaten'; mă lí tă ji $($ tă $\mathrm{j} \bar{i}=$ tě $\check{a}-\mathrm{j} \overline{1})=$ ' they say that come thou,' which may refer' to some particular 'they' alrearly mentioned, or else to an impersonal 'they' = 'people' and = 'you are toll to come.'

'Before the world was made' = dǒk dă mă kă-pŭt yil kā =' formerly before people had not brought out the world' (purt = H. 'fittc,' and is obviously the origin of the latter).

15. This 'ma' is used, of course, with all the tenses.

mă pó mwăt-fŭn $\bar{u}=H$. ' $a$-na buyga-r mu' = 'people are beating us' = ' we are being beaten' = lit. 'one with beating of us.'

mă mět nŭng kě lŭ-fã = 'people are going to bur'n my house' =' my house is going to be burnt.' 
dơk-(n)tī mă kă-pün brüng gnăn ='a long time ago one hatd griven me a hor'se' $=$ 'a long time ago I had been griven a hol'se.'

Note.-Consider the Hausa form 'an:o da shi' ='one has come with him,' i.e. 'he has heen brought.' It may be interesting to inquire whether this ' $a$-' comnotes to a Hausa mind the singular or the plural, that is, do they think to themselves, 'one has come with him,' or' 'people have come with him'? We find in the Angass that it is distinctly plural, i.e. 'mă'; and we note also that with ' $t^{-}$' are used the plural forms of the personal pronouns, e.\%. ' $a-n$,' ' $a$-7ia,' the same as in 'su-n,' and 'su-kia'; the ' $n$ ' and '-lia' not being used with the singular' pronoms, ' na,' 'lia,' 'yu.' Thus it may perhips be inferred that ' $a$ ' should be more correctly translated by the impersonal 'they' or 'people, folk' than by 'one.'

16. There is a for'm to express our 'a-running,' 'a-bent'; its construction is ' $\mathrm{kă}$ ' with the verb reduplicated, and corresponds with the Hausa rerbal form such as 'a-grje,' 'a-tsugune.' Thus-

ăn-nē nyī kă bār bār = 'I saw him escaping.'

ăn-nē nyĩ kă lăng lăng = 'I saw him abent' $=H$. 'c-tsu!fune.'

ăn-nē nyĩ kă wŭm wŭm = 'I saw him a-buried' =H. 'a-bizne.'

ăn-nē nyī kă sū sū = 'I saw him a-running' $=H$. ' a-guje.'

17. This 'kă' is, again, the same as the Hausa ' $a$ ' in such phrases as H. 'na ganshi a-doli i' ; ' $\bar{a} \bar{a}$, bai a-doki ba'; ' na ganshi a-gidda,' 'a-hainya,' etc. The Angass equivalents for the above are ăn-nē nyī kă brüng; ē è, nyì kă brüng kā; ăn-nē nyī kă lŭ, kă ār, etc.

18. The Hausa passive verbal noun can be translated by our forms in '-able,' e.g. H. 'yu-uva' = 'dlo-able,' ' ba ta amrua' = 'she is not marriageable,' 'ba stii lietar'ua' = 'it 
is not fordable, etc. 'There is a form in Angatss, too, which corresponds to this, and takes the for'm chin bè

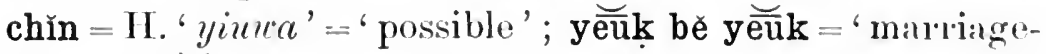
able'-(y cuk, 'to marry' is used only of women. 'T'o marry', of a man, is lă, which lit.= 'take,' 'capture,' ' seize'); děl bě děl = 'crossable,' 'fordatble'; chìn bě chǐn $\mathbf{k} \overline{\mathbf{a}}=\mathrm{H}$. ' ba yn-uwa' = ' not possible.' These can also be paraphrased by the for'm kè chin kä = 'not with doingr.'

Note._'This form 'chĭn bě chĭn' (= 'possible') is in all likelihood the conditional 'if he does it, he does it,' see chap. ix. para. 5 ; yeük be yeŭk $k \bar{a}=$ "if she marries, she does not marry,' i.e. she is not marriagealule; dèl bě dèl $=$ ' if it is crossecl, it is erossed,' i.e. it is cross-able or' fordable.

It might be noted here that the verb en be used both transitively and intransitively, e.g. pin dăm =" he broke the stick,' and darm pin = 'the stick hroke.'

19. For' the Hausa 'da.....da,' the conditional, see under" 'if' (chap. ix. para. 6).

20. '-dhr̆r' is of ten suffixed to a verb to denote reduplicated action, and cin be translated by the Hansia 'liuma'; be = ' to come back,' bě-(n)dhĭr = 'he has come back again,' yāl-dhřr = H. 'ya tashi liuma' = 'he has got up again.' tŭm-dhir $=$ ' he has come down again.'

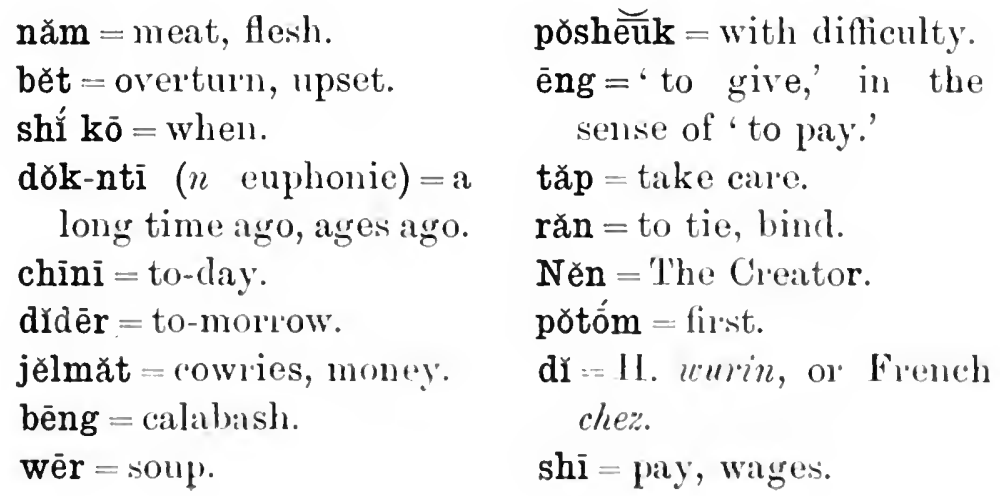




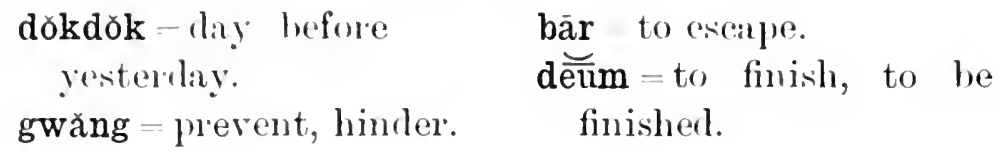

mă língăn tě kărăng-mă sĕ năm gŭrm = they tell me (or. I im told) that the Angass eat man's flesh.

mă nŭng lŭ = the house has been burnt.

mă chĭn nyī (kō) dǒk-ntī = it was done yearss agoo.

mă pün jĕlmăt-kĕnĭ nyi = he has been given his money.

măntă mă mwăt nyi = lon't let lijm be beaten.

gwǒlŏng kě lǐ tě ŭ-chĭn, bě u-chĭn = if the king saỳs Do it, lo it.

mă yē nyī chīnī à. dìdēr à ? = will he be caught to-rlay ol. to-morrow?

mă sìt nyī shǐ kō dăng è ? = when was he sold ?

mă bēt bēng wēr-kēni = his bowl of soup was overturned.

mă gwăng sŭ nyī pŏsheưk = he was with difficulty prevented fiom running away-(nyi is the dative=anhanna ma: $a=$ they prevented ruming away to him).

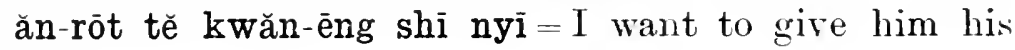
wages.

ăn-rōt tĕ kō mă mwăt nyī = I wish him to be beaten.

ă-lìrgăn kwăn-mět = tell me (so) that I may go.

măn ă-răn mŭn kĕ găk $(k \bar{a})=$ don't tie us together.

măn mă răn mŭn kĕ găk = don't let us be tied together.

ăn-wŭl ār nĕ ă-găm gnăn kĕshĕ̌uk = I will follow whichever load you show me.

Něn nyì dĕn ğhā (dĕn =H. aje) = may God preserve you.

Něn nyī yìt ğhā = may God leare you (prosperous, etc.).

mă kăt bī-nı̆ dĭ wē ? = from whom was this thing received?

măntă mă yīt nyī, kō nyī bār = don't let it be allowed that he escape.

sū dǒkdǒk, mă (kă) nē nyì kā = he ran away the day before yesterday, and has (had) not been seen. 
à-tăp măn mă tŭ ğhā = take care not to be killed.

pơtōm kō găk mět, dăng kō-chĕ kwăt = fiı'st onc went, then :nothes--(kwät = also).

shĭ kō mŭ rū, mŭ kăt mă kă tū nyĩ = when we arivell, we found he had been killed.

ă-lì(n) gwőlơng kō nyī lèb gð̌-lèb = tell the king to send a messenger.

lěok deưm à?= has the war stopped?

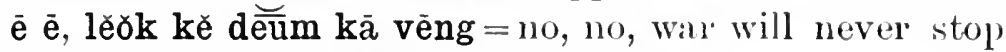
- (vēng very much drawn out, vè-ē-ē-ēng). ă-chĭn nyī kō kō-ň̀ = do it like this (or kō àn-ní). 


\section{CHAP'TER IX}

1. There are few Prepositions, and they are only used when absolutely necessary.

kĕ $=$ of, with, by, from.

shr $=$ with, by, frequently elided into š and even sě.

$\mathrm{p} \overline{\mathbf{1}}=$ because of.

$\mathrm{s} \overline{\mathrm{e}}=\mathrm{H} . \quad s a i=$ except, until ; most probably this is derived from the Hausas, as a good many Angass do not know it.

mă $=$ to, of, used when ' kĕ' would be amliguous, i.e. when ' kĕ' might mean 'with,' instead of 'of.'

These are not traceable to any known nouns or l'oots. Note 'pì' also = 'place,' 'spot.'

brüng kĕ gwŏlŏng = the lior'se of the king.

ăn-tū nyī shĭ (or š̀, or sě) săp=I killed him with an axe.

mă tū nyī kĕ (or shř) mwăt= he was killed by blows (beating).

mă yē bŭp kĕ (or' shř) shăng = they catch fish with a net. ăn-jī shĭ rōt $=$ I will come with pleasure.

sē dìdēr $=$ until to-molrow.

ăn-rōt bì-chĕ kā sēi năm = I don't like anything except meat.

pì kō-dă dăng ăn-lĕp nyī=because of it (then) I sent him.

wŏk nĕ ă-nē mă ăjiă = the house which you see is the Ajia's; in this last sentence 'kĕ ăjiă' would mean ' is with the Ajia,' i.e. possesses or holds the Ajia, i.e. that the Ajia is in it.

ār-nĭ kĕ jwāl dŭng = this road is rocky. 
ār-ň̆ shř jwāl dŭng = this road follows rocky places.

ăm shr shăng = the water is sweet.

ăm kĕ shăng = the water will be sweet.

2. The above show that there are very many occasions on which one might imagine one could use a certain preposition, which, however, would be wrong in practice. As a rule, however, 'kè' means r‘ather ' of than 'with,' while 'shì' lenotes only the latter'. 'The shades of meaning of 'kě' have already been noticed in chap. ii. par'as. 6-9, and chap. vii. para. 8, and chap. vi. para. 9.

3. The above are the Prepositions proper. There are other's which are nouns used prepositionally. Such are:-

bwīn = behind, lit. = ' the back.'

porkīn $=$ in fl'ont, lit. $=$ 'the for'ehead.'

năr $\mathrm{ke}=$ on top (kē = head).

bĭdēr $=$ under $=$ lit. ' the origin,' ' cause,' ' foundation,' 'bottom.'

nēr $=$ in the midst of, lit. $=$ ' the middle.'

dhĭr or dì =at the place (of) $=$ H. wuri-n and French chez, also H. a-wuri-n.

$\mathrm{kă} \mathbf{k e}=$ H. $\breve{c}$-lic̆n (for' $a$-liai-n) = about, with refer'ence to. dü̈n or nün = in, inside = lit. ' the insicle.'

kè $\operatorname{shī~kè~}=$ after' = lit. ' with foot of.'

Thus:-

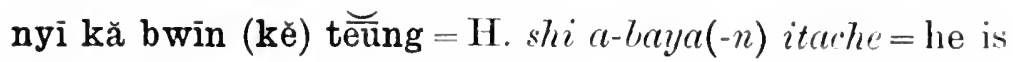
behind the tree.

nyì kă pŏkīn (kĕ) těung = H. shi a-gabba $(-n)$ itache $=$ he is in front of, etc.

nyī kă năr ké kĕ jwāl = he is on the top of the rock.

nyì bĭdēr jwăl = he is unler the rock.

ăn-nē nyī kă nēr kĕ mă= II. na !/ansłhi a-t:alilia-n-su= I see him in the midst of them.

kĕ tĕr dhĭr gworlong = he will sleep at the king's (place).

kă kế kĕ mè mă pó kớr ē ? = H. a lia(i)-n mine, suna facla $?=$ concelning what are they fighting? 
nyì dün work =he is in the house.

kè shī kě kō-dă, bè mă mèt = aftè this, they went.

4. ' $O r^{\circ}$ ' is not usually put in; when it is, 'kö' and 'kābè' or' 'ābē' are used, though the latter' mean rather' 'perhaps.'

à-jī kě brüng, kābẽ ghü̈, 'gnăn= bring me a hor'se, perhaps (or') a goat. More idiomatically this would be 'ă-jī kè brüng gnăn kābē kō ḡhü băng.

5. ' If' is 'kăt' or' 'kădăn,' but the most general way' of expressing our ' if ' is to leave out the 'if' in the sentence in which we should insert it, and precede the other' sentence with 'bĕ'; thus, 'if I go, I shall return' = 'ăn-mět, bě ăn-bě.'

'If you abuse me, I shall abuse you'=ă-kăs gnăn, bĕ ăn-kăs ghā, where the 'bĕ' = the Hausa 'koma.' H.= (idan) lia rayeni, zan lioma raye lia.

However' 'kădăn' or' 'kăt' sometimes introduces the first sentence, kădăn ă-kăs gnăn, ăn-kăs ghā, but better, kădăn ă-kăs gnăn, bě ăn-kăs ghā kwăt.

6. The above method can translate our conditional clauses, such as are renclered by the Hansa ' dla......la,' but as these last are somewhat indefinite, the conditional sentence is introduced by the 'indefinite pronoun' kō-mē, used as a conjunction. H. "da na sani, da ba na yi shi $b a^{\prime}=$ kō-mè ăn-măn, bĕ ăn-chĭn kā = had I known, I would not have done it.

kō-mē ğhā dí, bě mwöll-nă lǒk kě mūt kā = had you been here, my younger brother would not have died-(d ăuurin or akwoi).

kō-mē (n)fwǒt sheūk tŏk-fănă, bĕ mŭ yı̆r ānhā kā = had he listened to my talk, we should not have suffered thus.

kō-mè ăn-măn ābē, bě àn kā= H. da na san halika, da ba halitia ne ba. A better for'm is kō-mē ăn-măn ābē, bĕ yě ān kā gnēt= if I had known thus, it would not have been so. 
kō-mē ān kā, bě (yě) ăn-lí ğhā = H. inula ba halilia la, da na gaya maku. 'This yĕ, an emphatic pirticle, can be better inserted in every one of the above sentences after 'bě.'

kō-mē jì bě-ní dōndōn, bě yě dēr ăn-yāl; tăng kě jī kā, bě mwěn-fănă gĩ pär-chě dăng @ hatd he come yesterday, I should have started to-morrow; since he will not come, my going is postponed-lit. ' my going seeks another dily.'

$k \bar{o}$, instead of $k \bar{o}-m \bar{e}$, is ver'y often userl, and is just ins admissible.

7. ' But' $=$ dăng, of ten omitted. I shall go, but I'll return = ăn-mět, dăng bě ăn-jī; I like him, but I lon't like his father = ăn-rōt nyī, dăng ăn-rōt pŭp-kěnǐ kā.

Note that dăng, introducing a principal sentence, means 'then' = H. 'saanan' or. '7ana,' and is incessantly employed in narrations and stories; thus, dăng tăkwără mĕt jit shwě ; dăng năng ăs ; dăng ăs jì dĩ ; dăng kăt tăkwără lă shwě dün pil ; etc. = 'then the partridge went to cook the corn; then she called the dogr then the dog came there; then he found the partridge pecking the corn in the grass,' etc. '

8. 'Before' = dôk-dă, kắ-pì-dǒk, kắ-pi-dōn.

$\mathbf{d o r k}=\mathbf{a}$ former time $(=\mathbf{H}$. dī $)$, and the '-dă' is the definite article or demonstrative pronoun (chap. i. paras. 2 and 3).

kă-pi = H. a-vuri ; dōn, sometimes dön, is possibly an euphonic or softer form of $\mathbf{d} r \mathbf{k}$, it also means 'yesterday.' Both are used adverbially.

Before he diel =dǒk-dă bě kă-mūt $k \bar{a}=$ lit. for'merly when he had not died.

Before we came $=$ dǒk - dă bě $m \bar{u}$ kă - jī kă (narrative tense).

$=$ dǒk $\mathrm{dă} \mathrm{bě} \mathrm{mū} \mathrm{jī} \mathrm{kā.}$

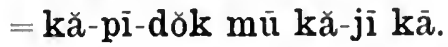

$=k a ̆-p \bar{i}-d o ̄ n ~ m \bar{u}$ kă-ji kā, and, idioma- 


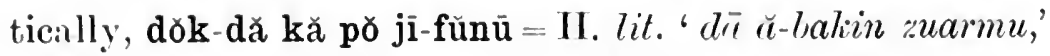

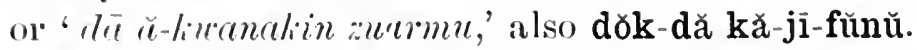

Before the world was made = dǒk-dă mă kă-pŭt yīl kā, or $=$ dǒk-dă Něn kă-tēr yīl-nĭ kā.

Before you go, bring the money = dā bè ă-kă-mět kā, ă-ji kě jělmăt-dă; or, better, à-kŭt ă-jī kě jělmăt-dă dăng kō-ă-mět, where ă-kŭt, though of verbal for'm = 'tuliuna' (see chap. x. para. 1, p. 72) = not yet.

First, bı·ing it = à-kŭt ă-jī kĕ nĭ dăng, i.e. befor'e you do anything else; I will give it to you before I go=ăn-kămět kā, ăn-pün ğhā dăng.

kă-pi-dōn has also the meaning of 'since' = H. tündă.

kă-pī-dōn gnăn dì (=H. tunda ni ke) ăn-kă-nē kō-nyī $\mathbf{k a}=$ since I was here (i.e. in this world = since I was born) I had not seen its (his) like.

kă-pī-dōn ăn-jī bě-nì tār sār pŏ fīr =It is fourteen months since I have been here.

kă-pī-dōn mă(kă) lěngăn = since $I$ was born $=\mathbf{H}$. tun aliahaifeni=lit. since they bore (or, begat) me.

kăs = to curse, abuse.

tār = moon, month.

săr $=$ ten.

săr pŏ fīr = H. goma sha

hudu $=$ fouteen.

shwě $=$ coi'n.

as $=$ dog.

pil $=$ a spiky giass $=\mathbf{H}$.

tof $c$. jīt shwě = H. daffia g ğt$k a i w \bar{\imath}=$ special preparation of corn for food. y $\breve{e}=$ a particle.

gnēt, an emphatic particle. băng = a particle. dăk = a particle. mōr $=$ energy, exertion $=$ H. coniya.

ú-chĭn $k \bar{o}-n \check{i}$, bě mŭ(kă)jī kā = do this before we come. Note this might also mean 'if you do this, we do not come,' and so, to avoid ambiguity, we get it idiomatically,

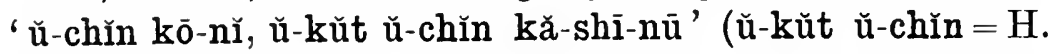
kiu (tuliuna) liu yi ; kă-shī-nū = H. a-sau-nmu, or $a-b a y a-$ nmu. 
kŭt is used very idiomatically (see para. 8 supr $a$, and p. 56 under $k$ indi).

ă-kŭt ă-chĭn = II. lia zamma yi, or tukuna lia yi.

ă-kŭt à-tăng $=$ H. lia zamma liddaya-ua, or lia tuliuna lice kiclaya.

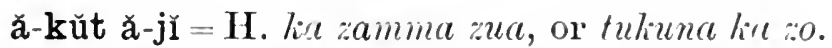

ă-mět bì-fã ; dăng kădăn ă-mèt, bě ăn-pün jělmăt(-fā) ghhă $k \bar{a}=$ be off with you- $(=$ H. tatji abinlia $)$-but if you go I shall not give you (your) money.

$\breve{\text { u}}$-chĭn shř mör $=\mathrm{H}$. lia yi da aniya. This is only said by women; a man would say ŭ-mōr ŭ-chřn.

'Is there a roal from Bauchi to Gwortok?' As there is no preposition for 'from' or 'to,' as here, this hats to be paraphrased : mă kăt ār gārū kō mă mèt gworrtǒk dā ? (dā = dì à ?), or àr dì wē gārū düm gwơrtơk à ?

$\bar{e} \bar{e}$, ār düm gworrtǒk dì-kā =no, there is no road to Gwortok.

ăn-kăt nyī dĭdhĭr $=I$ got it from him (dĭdhĭr $=I$. wuininga, or F. chez 7ui).

ăn-kăt nyi kă-pì-fā = I got it from you (kă-pī-fā $=\mathrm{H}$. a-vuri-nlia).

ăn-fwǒt nyī dhĭr Gơfwăn = I heard it from Gơfwan.

pì-dă, ă-chĭn shĭt-nì dhĭr-nă = on this account, do this work for me.

kĕ tēr d̆dhŭr $=$ he will sleep at his place $=H$. vurinsa, (or F. chez lui).

kě tēr dĩ măt, kābē dí gwǒlóng = he will sleep at the woman's or the king's (house).

kõ-yē sū jĩ dă= the one that ran away has come. ŭ-wē dắk = all right, go. 


\section{CHAP'TER X}

1. 'Yet'=dăng, or kŭdĭ ; kŭdĭ dăng = not yet =H. tulinna.

He has not come yet = kě jī dăng kā.

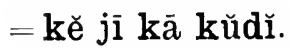

$=$ kĕ jī dăng kā kŭdĭ.

'They have not come yet = mă jī kā mă kŭdĭ.

kě jā (=kě jī à) kĕ jī kā ? = will he come or not?

kŭdĭ dăng $=$ not yet.

ă-tēr dăng = sleep, still = H. lia lillana tuliuna.

tēr kŭdı̌ dăng = H. livanalii tuliuna = 'the time is not up yet'; e.g. if some one is expected in seven days and a man asks, after four days, if he has come, the answer would be tēr kŭdĭ dăng.

kŭdĭ găng = it is still unripe.

kŭdĭ is sometimes contracted to kŭt; kŭt pǒ nyŏk = he is still breathing; kŭt bĕ-nı̆=he is still here.

As an example how any word may be used as a verb by the addition of the pronominal prefixes, take this wor'd ' kŭt,' which = 'still,' 'yet,' and compare its uses on pp. 54 and 55 .

2. 'When ?' = shî́ kŏ dăng; when = shî́ kō.

When will he come? = kĕ jī shĭ kŏ dăng ?

Not for ten days = kĕ tēr săr dăng.

Since when did he do it ?= dŏk chĭn shí kŏ dăng.

Since when has he been ill ? = dŏk lě shĭ kŏ dăng ?

'Whenever,' 'at any time' = kō shí kŏ dăng $=$ H. lio yaushe.

Do it at any time = ă-chĭn kō shî́ kŏ dăng. 
I will tell you when to go = kế kě mět-fā (bě) ăn-lí ğhā or shĩ kō ă-mět, bě ăn-lì ğhā.

3. 'Where' $=$ pi ner $=$ 'the place which'; where? = nĭn è?

à-mět nin è ? = where do you go ?

pì ně ăn-mět lă-ğhā kā = where l'm going is no concer'n of yours.

pī ně ăn-mět ăm-ḡhā dĭ-kā = where I'm going is no concern of your's ( $=$ H. ba rumlia $b a)$.

pĩ (ně) kě mět kěshěuk, ă-lă shì-kěnì = H, wuri-nda zei tafii duk lia bi shi= wherever he goes follow him.

ăn-kăt bì-sē nĭn è? where shall I get food? Answer kō-nĭnē = anywhere.

4. 'From.' There is none; sometimes kě is used (see para. 8).

I returned from Bauchi =ăn-wē gărū ; (wē = to return home), lit. I have come home Bauchi; the context shows it is from Bauchi.

Where do you come from? = ă-wē kă-pi-pi-dăng(ē) ? (or ă-wē nĭn è) dăng ă-ji $?=$ lit. ' you homed from where, then you have come?'

I got it from the king = ăn-kăt nyī dhy̆r (or dì) gwőlong.

Take it from him = ă-lă bì (n)sār-kěnì.

I shall do it from to-day till the day after to-morrow = ăn-dōm (ăn-chĭn) chīnī hăr pŭdì = I will commence ( $I$ will do) to-day till to-morrow.

He has done it from a long time $=$ dǒk ntî dăng chĭn.

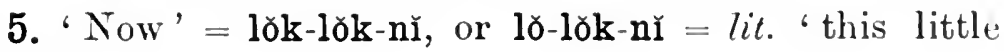
little.'

Just now he said it, and he denies it again = ghür shĕk tŏk lǒk-lơk-nĭ, bě chī kwăt.

6. 'Together' = kě chǐt, kě găk, pơ găk.

Let us go together $=$ mŭ mĕt kě chít.

I will go together with you = ăn-mět kě chǐt kě ghā. 
Let's both make friends togrether $=$ kĕ nyī kě gnăn mŭ chĭn shēr kĕ găk.

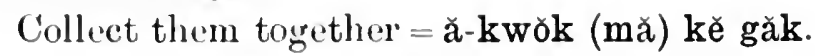

7. 'Near' = kŭs. Pankshlin is near ' Fier'= Păngchĕn dō kǔs kě Fyěr.

8. ' Far' = sōn, Bauchi is far from Fier = gārū sōn kĕ Fyĕr.

I am far from doing it = ăn-chĭn kā, sōn dŭng =lit. I do not lo it, very far.

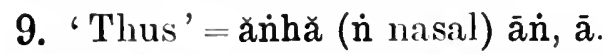

We like it thus = mŭ rōt ànhā; 'thus they do'= mă chĭn ānihā.

găt mă chĭn ănhă = II. su lian $y \bar{\imath} h a k i k a=$ they are in the habit of doing thus.

10. 'How ?' = răng ē ? how will he do it? = kĕ chinn răng ē ?

I don't know how I shall do it $=$ ăn-chĭn răng è, ăn-măn kā = how shall I do it? I don't know.

Another method is, 'I don't know its doing'=ăn-măn chĭn-kěnĭ kā.

Another method, again, is ăn-măn bī nĕ ăn-chĭn kwănchĭn $\mathbf{k a}=\mathbf{H}$. ban sani abinda a an yi en yi shi ba = I don't know the thing which I shall do, that I may do it.

I will show you how to do it $=I$ will show you its doing = ăn-găm chĭn-kĕnĭ ğhă = H. zan nuna yiusa (ma) lia.

How far? = sōn răng ē ? How far is Fier?= Fyĕr sōn răng $\overline{\mathrm{e}}$ ?

11. ' Exactly,' ' absolutely' = kĕt kĕt, kwăp kwăp.

Divide it exactly, don't let one exceed the other = ă-rĭp kwăp kwăp, măntă kō-chĕ děl kō-chě.

12. 'Slowly,' ' bit by bit' = ' lī lì,' 'shídĭdĭ shĭdĭdĭ.'

Go slowly = ă-mĕt lì lì.

Tell it to him slowly (or, bit by bit) =ă-lè nyī shĭ́dĭdĭ shídìdr. 
13. 'Quickly' = lē lè ; come quickly = á-jì lè lè.

14. 'Truly' =zīn gnět; nyì dō dă.

15. 'For ever' = hăr găk, vēng or väng with a ver'y prolonged e and $\overline{\tilde{a}}$; it also = ' continually,' 'always.'

16. 'Only' = găk (the numeral 'one') sēer, which probably is the Hansa 'sai.'

I want nothing, only fowls = ăn-rōt bì-chě kā, kī găk.

I will not drink gruel, only beer =ăn-shwē wēr kā, sēè mðs, or', mððs găk.

17. 'Yes' $=\overline{\mathbf{e}}, \overline{\mathbf{1}}$, with the voice lowered. With the voice raiserl they answer' a call, like the Hansa ' nu'am.'

18. 'Perhaps' = kābē ; it also answer's at times to our' 'if.'

Perhapss it's true = kābē zīn, also ābē zinn.

19. "Whether'.....or" = kăt......kăt ; kābē......kābē ; ābē......ābē ; kăt, contracted from kădăn = rather, 'if'; kābē and ābē are more, 'perhaps.' Whether he'll come

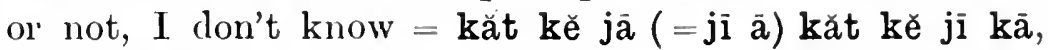
ăn-măn kā.

20. 'Certainly' = gnët ; cer'tainly he'll come, don't doubt it = kě jì gnèt, măn ă-kăk kā (or kăt).

21. 'No' = e e e, hāi, the latter is used more in the Hills; lă hāi nyī, or' kěnì = H. ya dauka masa $a a=$ ' he refused him.'

22. 'Unless,' ' Except' = mě......dăng ; sēê.....dăng.

I will not go unless I am well=ăn-mět kā mě (or sei) gnăn kām dăng.

Don't go unless you wish = măn ă-mět mě (or, sēi) ă-rōt dăng.

I don't want to fight unless I get a cause to = ăn-rōt lěǒk kā, mě (or sề) ăn-kăt fŭng lěǒk dăng-(fŭng = opening, window, etc.).

23. To do ' again' = bwǒk. I will not do it again = ăn-bwơk kā. 


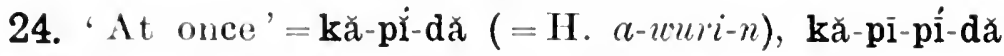

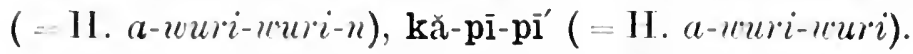

25. 'Sort of' = găt ànhā, kēn = H. iri (= seed, etc.).

This sort of clisposition ammoy's me exceedingly = sheǔk chĭn (= Ilausa 'Tulli') găt ānhā-nì (n⿳亠丷厂 = this) chōr gnăn kă-chōr-chōr. (For this fol'm, 'chōr kă-chōr-chōr,' com-

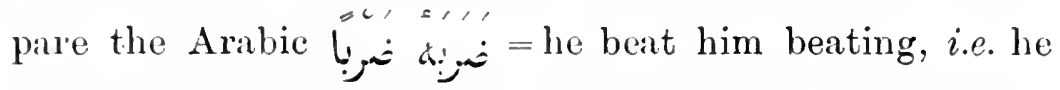
beat him severely); lit. it $=$ ' he annoyed annoying' (see chap. viii. 16).

măt găt ànhā-nĭ=lit. 'this sort of woman!'= 'what a woman!'spoken in anger.

bì găt ādà (another for'm of ānhā) wēr (= forbidden) mŭn kĕt kĕt = this sort of thing is absolutely forbidden to us.

gwŏ-nĭ kēn-kĕnì mē ? = what's the race of this man? also = what sort of (disposition) man is this ?

ăn-măn kēn kě bī-ní kā=I don't know what sort of thing this is.

In Hill Angass kōdī = găt ànhā; măt găt ānhhā-nì != măt dř ! (Hill Angasss).

găng $=$ ripe, ripen.

tēr $=$ to sleep, remain, lie down.

nyǒk = breath, lungs.

$\mathrm{w} \overline{\mathrm{e}}=$ to retui'n to the place

one has started from: generally 'home.'

ğhür = to lift up, take, carry.

zin $=$ ti'uth

ti $=$ ages ago, long ago $=$ H. tuni.

$\mathrm{tī}-\mathrm{nti}=\mathrm{H}$. tuntuni. chĭt, only used with kĕ $=$ together. $\operatorname{ch} \overline{\mathbf{l}}=\operatorname{den} \mathrm{y}$.

$\mathbf{k w o ̆ k}=$ to collect, gather.

hăr $=u p$ to $=$ Hausa har.

$\mathrm{ki}=\mathrm{a}$ fowl.

wèr = Hausa liumu, gruel.

mors $=$ beer $=$ gia .

shē or shwē = to drink.

$\mathbf{k a ̆ k}=$ to doubt, suppose not.

kām = strong, well in health.

fŭng = opening, window, cause.

wēr = for bidden, unlawful. 


\section{CHAP'TER XI}

\section{COMPARISONS OF ADJECTIVES AND ADVERTS}

1. Adjectives undergo no inflexion of any sort. Comparisons are effected by means of the verb dèl, "to surpass,' whose use corresponds exactly with the Hausa 'fi.'

2. 'This woman is pretty, but that one is prettier', can be translated in any of the following ways:

(a) măt-nĭ rīt (n)yĭt, dăng kō-pănă děl rīt nyī.

but that one surpassies beauty her.

(b) . . . , , dăng rît kĕ kō-pănă dèl nyī.

but the beicuty of that one surpasses her.

(c) , , , , , dăng kō-pănă dè̆l nyī rīt.

but that one surpasses her beauty.

(l) , , , , dăng kō-pănă děl nyī shǐ rīt. but that one supasses her with beauty.

For which the Hausa literal equivalent would be-

(a) mata nan keau-n gani, amma wachan fi keau, ta.

(b) , , , , , , keau-n warhan fi tu.

(c) , , , , , , , wachan fi ta kecur.

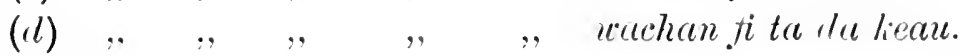

3. 'I ain stronger than you' = ăn-děl ğhā kām=H. na fi lia karifi = I surpass you strength.

'I am stronger than you' = àn-kām àn-dèl ğhā = H. nu karifi na fi $k a=1 \mathrm{am}$ strong, I surpass you.

'I am stronger thiı you' = kām-fănă dèl mŭ-ḡhā $=H$. karifi-na fi nc-ka=my strength surpasses your's. 
kām, from meaning 'strong,' hạs a secondary meaning, 'health,' thus àn-dèl ghā kām = 'I am stronger thau you,' or, 'I am healthier than you.'

'Honey is very sweet, but sugar is sweeter' =

shī shăng dŭng, dăng sŭccŭr děl nyī (shř) shăng = H. (a)

auma dali dayaure, amma succur fi shi (da) dadi.

shī shăng dŭng, dăng shăng kè sŭccŭr dèl nyi $=H$.

zuma dadi layaua, amma dedi na succur fi stii.

' $M y$ son is taller than yours, but yours is stouter than mine' $=$

yěm-fănă sōn děl mŭ-ḡhā, dăng mŭ-ḡhā děl mř-nă shr̆ mwăl.

yěm-fănă děl mŭ-ḡhā (shĭ) sōn, dăng mŭ-ḡhā mwăl děl mĭ-nă

'He is strongel' than any one'=

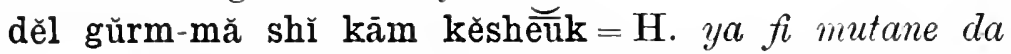
liariti dulia, lit. he surpasses men with strength all.

4. Thus, too, with adverbs-

'A horse runs faster than a man'= brüng sŭ děl gŭrm $=\mathrm{H}$. doli i ya gudu ya fi mutum.

' You do it bettel' than he' = ă-chĭn děl shĭt-chĭn-kĕnı̆ = H. lia ailii ya fi ailinsa.

' You do it better than he' = ă-děl nyĭ shĭ shrt-chĭn $=\mathbf{H}$. ka fi shi da aiti, i.e. you surpass him with work.

'Our tobacco is gool, but the Hausas' is better' = tābā-fănă shăng, dăng tābā (n)gwā děl nyī (shí shăng).

5. ' Rather' $=$ wŏk = H. gar'a ; (it) also = 'better.'

' I would rather die than tell a lie.'

(a) ăn-chăn kwŏlm (bě) wơk ăn-mŭt.

(b) , , , , , mŭt-fănă.

$(a)=\mathrm{H} .($ da) na yenke karia gara en mutu.

(1) , , , , , , mutu-na = my dying.

Note that chăn = to cut; chăn $\mathbf{k w o ̆ l m}=$ the Hausa 'yentie karia.'

(The above is a form of oath.) 
"Better a "jigwel" should seize me than I should go there' $=$

(kådăn) ån-mět pănă wơk jŭgwěl-mă yē gnăn.

H. da na tafji chan goma aljin su liama ni.

'I feel better' now, the fever has left $\mathrm{me}^{\prime}=$

wð̌k gnăn lơk-lők-ni (or dăk), fwơrm bwơt gnăn.

'He is a poor man, but $\mathrm{I}$ am better off' $=$

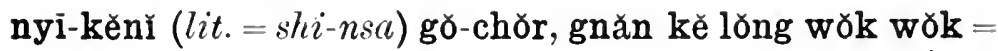

H. mai-talauchi, ni da dulia dama dama.

'Better a fool than no fool.'

djī dǐkā, wơk (n)djī bül-(büll = a particle).

'It is better so' = wơk ān, or wơk ànhā; (ānhā is more definite than àn, indicating some particular method mentioned $)=\mathbf{H}$. goma hakika.

'I feel better to-day' =wðk gnăn chĭnı̆ $(=\mathrm{II}$. goma gareni yau).

'Do you feel better than yesterdayy' = wơk ğhă chĭnĩ děl kō dōn-dōn à ?

6. The Superlative.

'God is the greatest of all' = 'Gorl exceeds every one in gr'eatness' $=$ Něn dèl mă kěshĕu shĭ kŭn $=H$. allak ya fi su duka girma.

Note the impersonal mă $=$ them, or people.

7. 'Too' is expressed by dŭng $=H$. dayar'a.

alitroi kaderlio? a a likoun ya yi masa fudi.

kwătěrk dī à? $\overline{\mathrm{e}} \overline{\mathrm{e}}$, fwơr wărn nyì dŭng.

Is there a bridge? No, no, river broad for it plenty.

'This dress is too long for him'= fătăt-nì soon nyĩ dŭng; ya yi mani yauka = dŭng gnăn dŭng, or wărn gnăn dŭng.

8. For phrases such as, 'as much as possible,' to the 
uttermost,' ete., there is an illiomatic use of 'düm,' 'to finish.'

'Ho honomed him to the utmost' ol' 'finish' = düm pün kŭn nyì = lit. 'he finished the givings' (or', 'he gave), honour to him.'

9. As has been noticel in chap. iv. para. 4 , there is no inflexion in gender. In most primitive languages, however, there are different words to denote the male and female of such animals as are in close contact with the people, such as domesticated animals, etc., and even when the language becomes elaborated, the primitive terms are still retitined; thus in Hausa we have, 'dolit, f. 'godia'; 'zaliara,' f. 'Tiara'; 'Tunsuru,' f. 'alivia,' etc.; and in English, 'hor'se,' f. 'mare' ; 'cock,' f. 'hen'; 'dog,' f. 'bitch'; and the very fact that we have to say 'he-goat,' 'she-goat,' shows that the goat was unknown to the early English as a domestic animal. In Angass, howerer, we do not get these differences. To denote the female, the wor'd măt, 'a woman,' or 'wife,' is used: thus brüng, 'a hor'se'; măt brüng, 'a male' ; mā, 'sheep' ; măt mā, 'an ewe'; nŭng, 'bull'; măt nŭng, 'a cow'; and so on. (The Hill Angass have kŭs = a cow.)

10. To lay emphasis on the fact that a horse, etc., is a male, the word 'gŏ,' ' a man' (the same word as the noun agent, see chap. v. para. 1), or gwŏ-mǐs, 'a husband,' is affixed; thus gŏ-brüng, gǒ-nŭng.

11. Some instances there are, but chiefly among names or nicknames, in which dă (m.), nă (f.) are prefixed to denote the gender'. Thus kūm is 'a navel,' and dă-kūm (m.), nă-kūm (f.), stand for' a person with a noticeable navel; 'a child born in the rain' is gó-fwăn or dă-fwăn (m.), and nă-fwăn (f.); or 'bor'n on the road' is gwŏ-ār (m.), nă-ār (f.). Kwŏm is 'twins,' and dă-kwŏm, năkwom, is ' the boy or girl of a pair.' Kūp, again, is the 'child born next after twins,' and is dă-kūp or nă-kūp (f.) 
according to the sex. But though the f. na is generally retainerl, the $\mathrm{m}$. dă is, as a rule, omitted, $\mathrm{g}(\mathbf{w})$ o being preferred.

Note.-There is one exception to the above, and it is, or may be, significant-so much so, that I have encleavoured to the utmost to see if it is only an exception, or not; or perhaps it is merely a coincidence, and this is, that jan also means the 'boy of a pair of twins,' and its feminine is jăna. However, it is the only word of this form that I can come across.

12. The pluial forms include both males and females, brüng-mă='hor'ses' in general, including mares; ăs-mă ='dogs,' including bitches; but 'mares' would be măt brüng-mă, etc.

wărn $=$ big, large, spacious. $\quad b w o ̋ t=$ to let go, release.

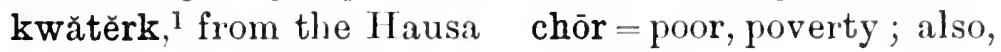

'liculerlio' = bridge. 'annoy.'

$\mathrm{m} \overrightarrow{\mathbf{a}}=$ slseep $=$ tŭm in Hill $\mathbf{k w o r l m}=$ a lie.

Angass. fătăt $=$ cloth.

bül $=a$ particle $=$ incleerl,$\quad k u ̆ n=$ important, importetc.

ance, dignity.

jrgwěl = the loeal spirit. $\quad \mathrm{mwăl}=$ stout, robust.

yē = to seize, catch. $\quad$ tābà = tobacco.

fworm =: fever.

1 kōl is the nearest Angass worl for a bridge. 


\section{CHAP'TER XII}

\section{THE NUMERALS}

1. There are distinct separate words for the numerals up to and including six. They ar'e :-

$$
\begin{aligned}
& \text { găk = one. fïr or fîer }=\text { four. } \\
& \text { bāp }=\text { two. } \quad \text { pēt }=\text { five. } \\
& \text { kwān }=\text { three. } \quad \operatorname{pim} \bar{i}=\text { six. }
\end{aligned}
$$

Among the other dialects 'two' is also ' $\nabla$ ŭl,' not in counting, when it is 'bāp,' but in combination, thus 'two horses' = brüng vŭl. 'Three,' too, is 'kŭn,' and 'four' is ' fēr' and 'fār,' in these dialects.

2. Above six, the numerals are compounded with ' po' ' $=$ 'the mouth,' which is equivalent to five, so that:

$$
\text { pŏ-bāp = seven. } \quad \text { pŏ-kŭn = eight. } \quad \text { pŏ-fār }=\text { nine. }
$$

3. 'Ten' is 'sār.' This may or may not be an idiomatic use of sār, which means 'a hand,' and also the 'fore-limb' generally.

4. By the aid of the prefix ' $k \bar{o}$ ', these numerals become substantives. Thus, in answer to 'how many horses have fallen?' the answer would be 'two have fallen,' or 'eight have fallen' = 'kō-bāp mă 'gū,' ' kōo-pŏ-kŭn mă gū.' But the ' $k \bar{o}$ ' forms, again, are only used in reference to animals or things; if to men, one must say 'gŏ-bāp mă gù' or 'gŭrm pŏ-kŭn mă gū.' 
5. Above 'ten' we get:-

$$
\begin{aligned}
& \text { sār pǒ-găk, or simply pơ-găk = } 11 \text {. } \\
& \text { "pó-bāp, } \quad, \quad \text { pó-bāp }=12 \text {. } \\
& \text {,, pó-kwān, ,, pó-kwān }=13 \text {. } \\
& \text { "pó-fìr, , } \quad \text { po-fìr }=14 \text {. } \\
& \text {, pó-pēt, } \quad, \quad \text { pó-pēt }=15 \text {. }
\end{aligned}
$$

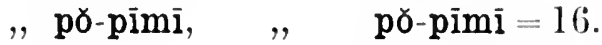

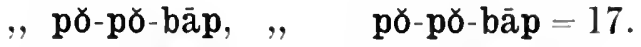

$$
\begin{aligned}
& \text {, pб-pó-kŭn, ," pó-pǒ-kŭn }=18 \text {. } \\
& \text {,, pǒ-pǒ-fār ,, pó-pó-fār =19. }
\end{aligned}
$$

tyěrk bāp $=20$, where tyěrk apparently $=10$.

Then-

$$
\begin{aligned}
& \text { tyerrk bāp pơ-găk }=21 \text {. tyěrk kwān pó-găk }=31 \text {. }
\end{aligned}
$$

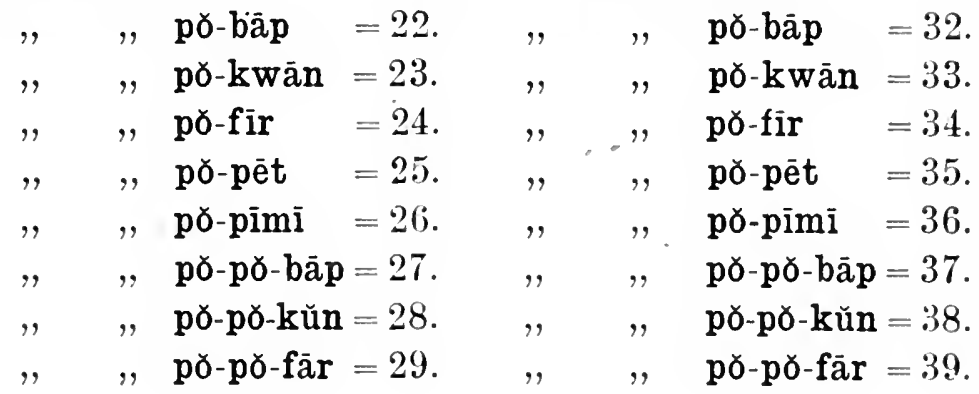

$$
\begin{aligned}
& \text { tyerk fir }=40 \text {. } \\
& , \text { pēt }=50 \text {. } \\
& , \quad \text { pīmì }=60 . \\
& , \quad \text { por-bāp }=70 . \\
& , \quad \text { pǒ-kŭn }=80 \text {. } \\
& , \quad \text { po } \text {-fär }=90 . \\
& \text {, sãr }=100 . \\
& \text { tyěrk sār pŏ-găk }=101 \text {. } \\
& \text {, " } \quad \text { pó-bāp }=102 \text {. }
\end{aligned}
$$




$$
\begin{aligned}
& \text { tyěrk sār pơ sār } \quad=110 \text {. } \\
& \text {, , pŏ sār pŏ găk = } 111 \text {. } \\
& \text {, , , pó tyĕrk bāp }=120 \text {. } \\
& \text {, " , , , kwān }=130 \text {. } \\
& \text { And so on. }
\end{aligned}
$$

$200=$ tyěrk sār tyěrk sār pī bāp =100, 100, two places (or times).

$300=$ tyĕrk sār tyèrk sār pī kwān =100, 100, three places (or times).

$1000=$ tyěrk sār pī sār $=100,10$ places (10 times).

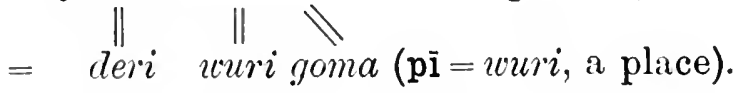

6. The Hausa ' leri', however', is coming into use, and the hundreds are counted with its help, e.g. děrĭ bāp, dĕrĭ kwān, etc.; also děrǐ-kěnǐ bāp, dĕrĭ-kĕnĭ kwān, i.e. 'its hundred two,' 'its hundred three,' and so on.

When not counting up to the 100 , sār găk in ordinary conversation means 100 as of ten as 10 .

7. This 'po' is used idiomatically as in Hausa; e.g. baliinsu naı $a=$ pŏ mă răng è ? = 'what is their value?'; po

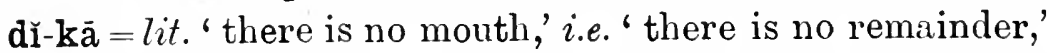
is used with the 10's to denote 'exactly'; thus tyerrk bāp pó dí-kā = 'exactly 20' (see also para. 11 seq.).

kük is also used to denote 'exactly,' or to emphasize po dì-kā; brüng mă săr kük pŏ dĭ-kā = 'the horses are exactly 10.'

Note sār, though as a rule it has a long $\bar{a}$, is often pronounced with a short one.

tyěrk sār kǚk = ' exactly 100.'

They are only $2=$ mă bāp găk (note that găk also= 'alone,' ' only').

There are only $27=$ mă dĭ tyěrk bāp po pó bāp $(=H$. su akwoi, etc.). 
mă kwān wē kwān, dð̌k kè-mă dō dā = 'they are only three, that is all absolutely' $=\mathbf{H}$. su guda ulin ne liadai, iyaliansu lie nan.

8. To avoid the use of the cumbrous higher numerals, the Angass have a system well established, by which the numerals mentioned are multiplied by 2,3 , or 10 ; this they call the "Notation of the Angass" = bi tăng kè Kărăng-mä-(tăng = to count); for instance, in referring to things which it is well understood must mount up to a large number, the multiple 10 is inferred, e.g. if a man is asked bow many bundles of corn he has harvested, he may answer "pò-fär" $=9$. Here the context shows he must mean 90 , as 9,18 , or 27 bundles would be manifestly too small, for it is known he must have somewhere about 100. This multiple 10, however, is confined to corn bundles.

ă-gyı̆p shwè-dă mă răng è ? = ' How much cor'n have you harvested ?'

ăn-kăt pð-fär, torng sě = 'I have got 9 [i.e. 90], enough to eat.'

9. In using the multiples 2 and 3 , however, it is usual to add 'tăng bāp bāp,' ' tăng kwān kwān,' i.e. ' count by 2's,' 'count by 3 's'; for example, after any one day's work of harvest, the bundles obtained are put together in 3's, so if a man counts 9 such, he knows he has 27 altogether.

10. Nearly everything else is counted by 2's. Thus-

ăn-sitt kẳng săr, tăng bāp bāp= 'I have bought 10 hoes counting by 2 's,' i.e. 'I have bought 20 hoes.'

11. In counting by 2 's, there is frequently 1 over, the odd one; this is called 'běgwir' ; gwir = 'unpaired,' and is applied to a bachelor or spinster, or any one unmarried.

' $p$ d,' again, is the odd amount, of numbers, above 10 ; if the whole number is less than 10 , then the odd amount 
above 5 ; thus po-kenr is the 7 of 17 , the 9 of 19 , etc. (see para. 7).

àn-těp pó-kěnĭ lă bē = 'I let you off the odd amount.'

sãr kĕ jĕp = ' 10 with its childıen,' i.e. all the numbers over 10 and under 20 are called 'the children of 10.'

And so, too, tyěrk bāp kě jěp, tyěrk sār kè jěp, ' 20 with children,' etc.

jěp (or jèb) kè ké̀ $=$ H. yaya akai=the odd numbers above the 10's; găk lǐss or găk lĭ-lǐss (for lǐss lǐss)= ' exactly 1.'

12. Distributive numbers are, as in Hausa, expressly by ' 1,1 ' ; ' 2, 2,' etc., i.e. ' găk găk,' ' bāp bāp,' etc.; thus, ' divide it among them by 4's' (or, 4 each) = ă-rīb mă fïr fïr.

13. The Ordinals are formed by the prefixing of 'dă' or ' gŏ' :-

$$
\begin{aligned}
& \text { dă găk, or gŏ găk = first. } \\
& \text { dă bāp, or gŏ bāp = second. } \\
& \text { etc. etc. }
\end{aligned}
$$

Note.-Gŏ pŭtōm = 'the one in front' (= gǒ pŏ-kīn), rather than 'the first.'

14. 'Once,' 'twice,' etc., are formed rather curiously; viz. by the aid of 'shī', 'a foot,' or 'shăk.' (Note in the Hausa 'sau daia,' and 'sau,' 'a foot.')

shī gak, or shăk găk = once.

shī bāp, or shăk bāp = twice.

shī sār, ol shăk sār = ten times.

15. Fractions.

yit ='an eye'; and also 'direction' or 'side,' and so 'a portion.'

ă-bē yît-nì = ' come back to this side.'

ă-jī yìt bě-nĭ or bǐ-nĭ = ' come to this side' (where I am). děl yit păntōn $=$ ' he has crossed to the other side.' 
Divide it in to 10 (parts) = à-rìb mă sār (note the pl. mă).

Give him 3 portions of it = a-ěng yìt kwān nyī.

, " $5 \quad, \quad, \quad=$ ă-ĕng yìt pēt nyì.

Beyond this there are no means of expressing fractions, but it suffices.

Give him $\frac{1}{10}$ th $=$ a-rīb mă sār, ă-ĕng yìt găk nyī=divide it into 10 and give him one portion.

Give him $\frac{4}{7}$ ths = ă-rīb mă po-bāp, ă-ěng yīt fīr nyī.

16. kwăng $(=$ H. woje $)=$ 'direction,' 'side,' and can also be used in place of ' yīt,' e.g. ă-pün kwăng găk gnăn = 'give me one portion.' When, however, 'one portion,' only, is used, it means 'a half,' thus the above sentence really is 'give me a half.'

17. 'To measure' = găm ; găm sār = 'to measur'e by cubits,' i.e. from the elbow to the finger tips.

18. găm kā= 'cheap,' but always used with ' sitt,' 'to sell' or 'buy.'

găm dŭng = 'dear'; bì-dă găm dŭng = 'this thing is very dear.'

kè $\mathbf{k} \dot{e}=\mathbf{H}$. da liai= 'something on top,' i.e. 'profit.'

pǒ-shī = also, 'profit.'

ă-sīt bě ă-kăt kă ké = 'if you sell, you will get a profit.' ăn-kăt pŏ-shī dŭng dŭng = 'I got plenty of profit.'

sě (=lit. 'to eat')=" to cheat'; sě gnăn kŭk= 'he cheated me indeed' (or badly). For kě kế may also be used kă $\mathbf{k e ́}=$ H. $\breve{a}$-kai.

I measured it, its breadth is 12 feet = ăn-găm, bänn-kěnĭ găm shī săr pǒ-bāp.

I weighed him out six measures = ăn-găm nyī dē pìmī.

What is the height of this tree? = sōn kè yōm-nĭ răng è ?

Its height is that of five men = sōn-kĕnĭ dār por gŭrm pēt (for 'pó', see para. 7, and chap. vii. para. 12).

'This is dear, I can get it cheitper at Bauchi = bì-nì mă 
gàm dŭng; ăn-kăt gārū mă găm kā. N'ote the pl. ' mă'; also that one cannot express 'cheaper' and 'dearer'; one cannot say directly, 'this is cheaper than that.'

How many times have I told you not to do so? = shi (or shăk) kō răng(ē) gnăn pǒ lì kění ḡhā, măn ă-chĭn ānhā?

'I'wenty-two times = shī (or shăk) tyěrk bāp pŏ bāp.

The last time I showed you how to do it, you told me you under'stood = dǒk (or kō) kă shī ăn-găm chĭn-kĕnĭ ğhā, ă-lēn̄ăn tě(nĕ) ă-fwǒt.

I don't care a little bit $=f(w) \overline{i t}$ gnăn dìt kā, or ăn-lē kē dìt kā, or ăn-lē bŭt-kĕnĭ dìt kā-(dīt=a little bit = small, short, etc.).

Don't you care ? = ă-lē bŭt-kĕnĭ kā ?

Of course I do (I care) = ăn-lē bŭt gnēt.

Tell him not to cross over to the other side; the place is dangerous ; let him go round = ă-lě nyī măn děl păntōn ; pī-dă büss ; nyī wăng, nyī wăng.

If you cheat me, I will not buy from you again=ă-sè sìt gnăn, bě dēr mŭ sī-sīt (= sìt sìt) kā, or' bě ăn-bwǒk sīt kě ğhă kā-(dēr = 'to-morrow,' and is used idiomatically for 'for the future').

I don't agree to your price; it is too much =ăn-lā è kě jělmăt-fā kā, dĕl $\bar{a}=($ lit.) I don't take 'yes' for your' money, it sulpasses thus.

Give it to the fourth (man) = ă-pün nyī gŏ-(or dă-)fïr.

Give it to the seventh (woman) = ă-pün nyī gŏ-(or dă-)pŏ bāp.

If they get $6 \mathrm{~d}$. each, will that be enough?= mă kăt sīsi sīsī, bě tǒng ā?

Yes, just right $=\bar{e}$, tŏng gnèt, or tŏng èt.

You are a wealthy man, how many sheep have you? $=\bar{g} h a \overline{~ d o ̄}(n)$ gwǒlǒng, ğhā kĕ mā kō răng è ? (not mā kě ḡhā).

I had eighty, but twelve have died = dǒk gnăn kĕ tyĕrk pŏ kŭn, dăng sār pŏ bāp mūt. 
Come away, this man is dear = ă-bē, gwŏ-dă rit sìt kà.

Are your houses far ipart? = ŭ-tŏng bē wŭn sōn à ? mŭ lē lū d̆́-shăk dí-shăk = we have built them close togrether. 


\section{CHAP'TER XIII}

\section{THE INDEFINITE PRONOUNS}

1. These are somewhat complicated, and deserve fuller mention. The interchangeable usages show niceties of expression. Nost of them are clear enough, but some baffle analysis, and can only be classed as colloquialisms or idioms.

2. Thus, "Whatever thief you see, catch him," may be one of the following:-

wăt, ně ă-nē kěsh ̌ưk, ă-yē nyī = H. barao, da ka gani duk, lia liama shi.

kō-wē wăt, nĕ ă-nē, à-yē nyī= H. kovani barao da ka gani, ha kama shi.

kō-mē wăt, nĕ ă-nē, ă-yē nyī = H. komi barao da ka gani, lia kama shi.

kō-wē, à-nē wăt, à-yē nȳ̄ = H. liowani, ka gani barao, ka liama shi.

kō-mẽ wăt dăng, ně ă-nē, ă-yē nyī.

kō-wē wăt dăng, ,, , , , , ;

kō-wē-wē, nĕ ă-nē wăt, , , ,

kō wăt dăng, nĕ ă-nē , , ,

kō-yē wăt dăng, nĕ ă-nē ,, ,

kō-mē wăt kō dăng, ně ă-nē, ă-yē nyī.

kō-wē wăt kō-dăng, , , , , , ,

kō-mē-yē wăt dăng, , , , , , ,

kō-mē-wé̀-wē wăt dăng, ně ă-nē, ă-yē nyī.

kō-wē kě wăt nĕ ă-nẽ ă-yē nyì. 
3. Again, 'give me anything,' is, besides, the usual forms.

ă-pün kō-mè-mế gnăn.

à-pün kō-dắng-ē gnăn.

4. 'Who will go?' = wē kě mèt è ? The answer, 'anyone' is any of the following: kō-wē, kō-mè-wè, kō-dăng, kō-mè-yè, kō-mè-dăng, kō-wā, kō-mē kō-dăng, kō-wē-wē, kō-mè-wă-chā, kō-mē-wā, kō-mē-wē-wē.

5. 'Which one has fallen?' = kōodăng tē ē ?

$\mathbf{k} \overline{\mathbf{o}}-\mathbf{n} \overline{\mathbf{l}} \mathbf{k} \overline{\mathbf{a}}, \mathbf{k} \overline{\mathbf{o}}-\mathrm{che} \mathbf{e}=$ not this one, another.

$\mathbf{k} \bar{o}-\mathbf{d a ̆} \mathbf{k} \overline{\mathbf{a}}, \mathbf{k} \bar{o}-\mathrm{che} \mathbf{d} \mathbf{1}=$ not the one, there is another.

6. brüng-chē, 'a certain horse,' can also be expressed kō-chē kè brüng = 'a certain one of (a) horse'; brüng-pănă also can be said kō-pănă kĕ brüng; which suggests that in Hausa 'kowani mutum' was, originally, 'kou'a na mutum,' which would account for the feminine form 'liowa ta mata.'

7. 'How many went?' = kōo-răng mă mět è ? and also

$" \quad, \quad, \quad=$ kō mă mèt răng è ?

$=$ the ones they went how many?

Those who stayed are two $=$ kō mă torng băp.

8. In calling out to any one, especially at night:

'Who's there ?'= wā mà ē?

$$
\begin{aligned}
& \text { = wă-chè mă è? } \\
& =\text { wā-mă dō dē ? (for dō dã ê). } \\
& \text { = yē mă mă è ? (in anger). } \\
& =\text { yē wă-chè ? (sing.). }
\end{aligned}
$$

The first four are, of course, the plural forms, as people who come in such a way, e.g. stealthily, at night, etc., as to require to be called out to, do not, as a rule, come by themselves, one at a time.

'Who is he ?' = kō-nì wē ?

$$
\begin{aligned}
& =\text { wă-chě dō nyì? } \\
& =\text { wè dō nyī }
\end{aligned}
$$


9. In commencing interviews, salutations, etc., the following are among the most frequent expressions :-

răng $\overline{\mathrm{e}} ?=$ how are you ?

bwāp $=$ well $=$ H. lafia.

bwāp à?=are you well?

bwāp gnèt = quite well. ğhā kām à? = al'e you well ?

gnăn kām gnēt $=$ I àm quite well.

kõ yāl kĕ lū kět kĕt wā?=lit. is the getting up of your house all right? i.e. is your house well? The fact of getting up, i.e. rising in the morning, shows good health, otherwise one would have to keep to one's bed; thus ă-yāl à ?=' have you risen?' i.e. 'are you well ?'-ans. bwāp rō-rốp (for rōp rōp), bí-chè $\mathbf{k a ̄}=$ 'absolutely well, nothing wrong,' or ăn-yāl = 'I have risen,' i.e. 'I am quite fit.'

wŏng lŏk à? Is there any little worry? (wŏng=lit. ' heat,' and thus (trouble') wŏng $\mathbf{k a}=$ no, no worry.

măt-dă-mă mă pǒ pŭt wā?=ar'e your women in good health?

mă(n)kām két két = they are exceedingly well.

mŭ-ŭdă-mă mă yāl wā?= and yours, are they all right?

ă-mwĕn kŭk à ? = H. ka zo kauui ne? =' 'are you merely on your journey?' i.e. 'you have not come here for anything special ?'

ăn-mwěn kŭk gnēt = I am just on my way.

zŭm, bí-chĕ $\mathbf{k a}=\mathrm{H}$. lafia, babu komi=quite well, there is nothing (wrong).

rit dō dā kē ?=is all well ?

gnăn kĕ chōr-fănă-chĕ $10 \mathrm{k}=I$ can just manage.

chōr = lit. poverty, chōr bŭt-nă= the H. bukatal rai, i.e. the necessities of life.

ghā kè sheưk tōk à?= have you anything to say? gnăn kě shĕk tǒk = I have something to say, yē më ?= well, what is it? and then the business portion commences.

If during the conversation a man wishes to agree with 
the speaker, he will interject àngèt (=ān gnèt) =so it is, or, it is so indeed $=\mathrm{H}$. hakkic liua.

At the end of the interview, if one is in the position to dismiss the other, he will say, ăn-bwort ğhā =lit. H. na saka $k a$, and $=$ H. na salamek $a$.

10. The word corresponding to the Hausa 'yaisuc' is bănga. It is derived from 'bang,' which = the H. waye; brt băng (in the Hills bĭt măng)=II. gai $i$ ya vaye; but how the final ' $\bar{a}$ ' comes in I do not know.

băng wŭn yā (or $\bar{a}) ?=$ H. gari ya waye muliu ? = Have you risen well? Has dawn found you well?

ăn-tðk băngā $\mathbf{w u ̆ n}=\mathrm{H}$. ina gaisheku = I salute, or greet, you.

ăn-lěb lěb nȳi băngāa $=I$ send him salutations.

11. The word tork, to speak, is used for 'to greet'; ăn-tork kě ğhā = lit. I speak to (with) you=How d'you do? It is used between equals, and by a superior to an inferior.

ă-tǒk kěnĭ mŭn = greet him for us.

ă-tǒk kě gwőlong gnăn=greet the king for me.

ăn-tŏk kě gwār = I greet him; gwār is used when speaking through a third person, and connotes, 'say to him that' (see p. 101, note 6, and p. 112, notes $8,8^{(i)}$ ).

dō-(n)gwār dŭng $=$ H. samunsa da gajia dayau'a (dō= trouble).

12. sè yil =lit. ' to eat earth,' and is used by inferiors to superiors. It is accompanied by the actual act either of throwing earth on their heads, and over their shoulders and backs, or of only going through the motions of doing so.

sẽ yill wŭn (=lit. ' he eats earth to you,' i.e. he salutes you) may also be used by a chief's spokesman to the petitioners, though the chief himself would never use the expression. 
13. 'Welcome' is $\mathrm{l} \overline{\mathrm{l}}=\mathrm{H}$. ' marhaba,' but is always followed by the particle kē or dảk.

lì-kē li-kè, or lì-dăk lì-dăk = welcome, welcome.

lì ğhā kè, or lì ğhā dăk = welcome to you (sing.).

It is used only to strangers, on arrival, or meeting on the road, and the usual answer is ' ŭn்mmmm! ghă po jā ?' (for jĭ $\bar{a} ?)=$ oh ho! so you are coming?

(li also means ' to spit.')

là lì =H. 'Tauka marhaba' = to welcome.

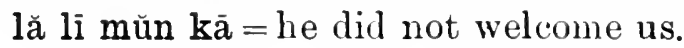

14. dē (to be distinguished from $\cdot d \bar{e}=$ 'a bowl,' which is pronounced with a curious '.d,' a sort of incipient click) is the word for an 'overlord,' ' master,' etc.; nȳ dē-fŭnū = 'he is our chief,' and also includes all that is meant by the slang expression, 'he's our boss.'

15. Among his subjects, to speak of a chief by his name shows contempt, and to address him by it, an insult. The lesser chiefs, however, are spoken of by their names, out of their hearing. One chief, too, will speak of another, and correctly, by his name, but not so to his face.

16. 'The king has sent to salute you'=gworlǒng lěb lěb tě mă tŏk kĕ ğhā=lit. 'the king has sent, that is to say that they should speak with you.'

Greet all your house and family = ă-tǒk kě kō lū kě gōămă kěshĕǔk; gō-ămă is a special pl. of 'gō,' ' a man,' and is used for ' relations.'

Greet your friend for me; is he well? = ă-tðk ke shēr-ḡhã gnăn; nyī (-n)kām à ?

17. 'To thank' is pắlăng; ăn-pălăng wŭn dŭng = I thank you very much; 'to be delighted' is tăm rōt, where tăm means to dance, to palpitate; and rōt=to like; ăn-tăm rōt kè nē-fā $=I$ am delighted to see you=lit. 'I thrill liking with the seeing of you.' 
$b w \varnothing t=$ to release; wøng = heat, to burn; bŭt $=$ the internal organs, and also metaphorically 'internal sentiments,' etc. = the H. zuchia; lă=take up; măng or băng $=$ to dawn, be clear, clean. 


\section{CHAP'TER XIV}

\section{'THE SEASONS}

1. The 'year' is 'yi.' It is counted from sowing time to sowing time, or from harvest to harvest, so that one year may possibly be a fortnight longer than another. It is not connected in any way with the motions of the stars or the sun. Accuracy as regards its length is not aimed at in the least, and no record of years is kept at all.

The Filani king of Bauchi, Ibrahima, penetrated to Ampier and burnt the town. His exploit is one of the landmarks of the history of the Angass, but no one could tell you how many years ago it occurred, though it is in the memory of men still living. (A.D. 1841 or 1842.)

No one, again, knows how old he is, exactly, or even within several years, if he is at all advanced in age.

The sowing time is regarded as the beginning of the year.

2. The 'month' is tär, which also means 'the moon.' They reckon from new moon to new moon, and count it as thirty days, though, of course, it is not so ; however, it may possibly be the remnant of an older system.

3. The seasons correspond with the Hausa.

tār kŭt $=H$. funturu; kŭt $=d \bar{a} r \bar{\imath}$, or cold.

lūn $=$ H. rānì : sometimes nēr lūn=H. tsalikan rani.

fơngfŏng = H. bazara, from fwăn = rain.

păs $=$ H. damana-(păs also = an arrow $)$.

tār bōghă, or $\mathrm{m}(\mathrm{w})$ ŏgh $\bar{a}=\mathrm{H}$. agazere=lit. ' month sunstrokes you.' 
pǒ wěp $=$ H. lakla; wěp $=$ harvest ; pr wěp $=$ commencement of harvest.

4. The times of the day are divided according to the usual routine of the daily work.

yāl kě pŭs = rising of the sun ; sunrise ; pŭs = 'sun.'

pŭs bĭt = early morning sun, about 7 A.M.

pŭs worng (shēuk) = the sun heats (the body), abont 9 A.M.

pŭs kê kă nēr $=$ sun's head in the middle $=$ noon.

pŭs tăp kè = sun bends his head = after noon.

pŭs por sin $=$ late afternoon, 3 P.M. to 4 P.M.

pŭs kĕ bwàp $=\operatorname{sun~has~got~cool~=~about~} 5$ P....

pŭs tè lŭ $=$ sun fallen to his house $=$ sunset.

pi rāp = the place is dark = twilight.

mă po gyěrm = they are gossiping = late evening, up to 9.30 or 10 P...

gŭrm mă kĕ sēm $=$ men are asleep $=$ after 10 P.M.

pār chők chők $=$ night indeed, indeed $=$ from 10 P.M. to 4 A.M $=$ the real night.

pó tām $\mathrm{p} \overline{\mathrm{i}}=$ first glimmering dawn.

bĭt, or, bĭt dŭng = 'dawn,' preceding 'sumrise' or yāl kĕ purs, and completes the cycle of the day.

5. purs is 'the sun 'proper', and not 'dily time,' which is kă băng băng or băng băng = H. sŭrŭr

pār is ' the night time.'

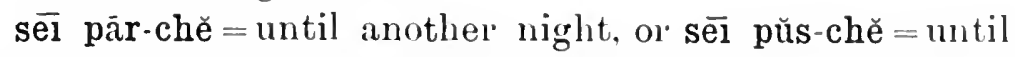
another sun = II. sai wata rana, but the former is much the more correct.

chĭn $\check{l}=$ to-day.

dèr $=$ to-morrow.

pŭdì = the day af ter to-morrow.

pŭdĩ-pănă = H. gritū = the day after the day after tomorrow.

dōndōn = yesterday .

dokdok = the day before yesterday. 
dokdok-pana $=$ the day before the day before yesterday.

6. There are no names for the days or months; and there is no such thing as the week. A few months are kept a record of, but not beyond seven at the outside. For instance, a woman (much less a man, even in the Hill Angass now) does not know how many months her pregnancy lasts before she gives birth.

7. 'The elements of astronomy are quite unknown, nor is there any sol't of speculation on the subject. There are names for a very few star's, e.g. 'Orion's Belt' is 'dăng $\mathrm{kwān}$ ' = 'the tail of three'; i.e. the first to rise is tără= the barer a, the next is ăs kĕ shì-kĕnı̆ = the dog following it, and the third is gwŏ(m)bi ăs kĕ shì pět = the owner of the dog following, close.

$\mathrm{m}(\mathrm{w})$ ălm is a 'star' in general ; mwălm bĭt = the morning star, mwălm pŏsinn=the evening star; mwălm pŭt= lit. 'a star has come out,' i.e. a falling star, which, they think, thereupon dies; zŭzŭk is the Pleiades group; pŭs yè tār =lit. the sun has seized the moon, i.e. an eclipse(zŭzŭk for zŭkzŭk).

8. tēr, 'to sit,' ' to sleep', is used like the Hausa 'livana' for 'a day'; bī lế-nì kě băl tēr găk kā, kō-mē tēr pēt bě tŏng $k \bar{a}=$ this illness will not be cured in one day, even five days are not enough.

Něn nyı̆ pün tēr zŭm mŭn = H. Allah shi ba mu kwanaliin lafï $=$ God grant us a prosperous time.

9. tër, however, is not always used when 'liwanali' or' its equivalents would be correct; e.g. H. 'kwanaki nan ban yi girma $b a^{\prime}=$ dŏk-dă bĕ ăn-kă-kŭn kā=lit. that former time, I had not grown big; i.e. at that time, I was not grown up.

Again, H. 'Tiuanali,' 'Toliachincla', 'saanda,' etc., are usually translated by the phrase corresponding to, say, H. $a-z u a-r m u=$ 'at our coming,' i.e. 'when we came' $=\mathbf{H}$. 
saanda muka zo; e.g. H. muka zo, amma kwanaki da muka zo, kana aiki.

$=\quad m \check{u}$ jī gnēt, kă-jī - fŭnū, ḡhā pŏ shît.

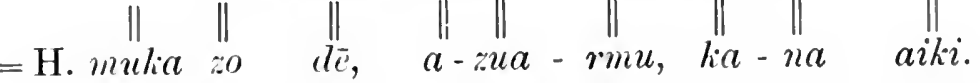

$=\quad$ we came indeed, at our coming you were working.

10. tēr, again, is used more widely than 'kwana' e.g. How old are you ?=yī-fă (or yì-fă-mă) kō răng è ?

In three months I shall be twenty = kŭt tār kwān kō ăn-tēr tyěrk bāp (kŭt = tukuna; kō ăn-tēr is the subjunctive).

Note.-Of men: he is three year's old = kě tẹr yì kwān. Of animals : $, \quad, \quad, \quad=$ kě chĭn yi kwān.

Where chin = the Hausa ' $y \bar{\imath}$ ' in all its idiomatic uses.

11. 'Wait a bit,' the Hausa 'sai anjima liadlan' = mă torng lơk dăng. (Note.-If the dăng were omitted, the sense would be a command = H. 'su jima liaddan,' or' ' ajima kaddan.')

băl = to get well, be ăs = a $\operatorname{dog}$. cured.

$\mathrm{d} \check{\mathrm{c} k}=$ formerly, former gwor-(n)bi $=$ II. mai $a b u=$ time. the owner.

dăng $=\mathbf{a}$ tail. băng = clean, clear, open. tără $=$ H. bareva, a gazelle. torng = to remain, sit ; to be enough. 


\section{CHAP'TER XV}

1. 'To be like' is ' kō'; nyì dō kō (n)gwŏlŏng = he is like the king; bì sheük-kěnĭ mă kō mă gwǒlorng =his appearance (or bodily features) is like that of a king; $=$ ăn-nē kō nyì kā = I have not seen (anyone) like him.

2. 'lă' = the H. dauka and liarla, and 'păn'=the $H$. rilike, are also used for 'to be like,' but their signification is more nearly our ' to take after'; nyi (mă) lă (n)gwŏlŏng $=$ he takes after the king.

ăn-nē bĕ lă(n)gwǒlŏng = I see he takes after the king ; i.e. he looks like the (or a) king.

ăn-nē brüng-dă, sheük-kěnǐ lă sheŭk kě nŭng = I see the horse, its body is like that of a cow.

yěm-fănă lă yĕm-fănă dŏk mūt $=m y$ child is like $m y$ child that died awhile ago.

lă shĕ̌k and păn shĕk are also 'to be like,' but includes 'to take the shape,' or, ' figure of.'

păn sheúk kō $k \overline{\overline{e u}} \mathrm{~s}=$ it takes the shape like a carrier's pad, i.e. it is round.

nyĩ păn sheūk kě pŭp-kěnĭ = he takes after his father (in appearance).

nyĩ mă lă sheūk kĕ gworlơng = he takes after the king.

Note.-The pl. mă in several of the above sentences indicates that there is more than one point in which the likeness occurs.

kō-nĭ mă lă sheŭk kě kō-nĭ = this one is like that.

3. 'To be nearly like' = chǒk (or' lơk ), kābē lă=lit. 'a little perhaps it is like.'

chǒk (or lơk) kābē lă minnă=it is nearly like mine. 
wŭjā lơk kābè lă vrìlì=a hippopotamus is nearly like a rhinoceros.

My child is nearly like the one that died = yěm-fănă lơk kăbē lă kō dơk mūt.

Also = yěm-fănă kŭs kě kō dǒk mūt.

Note- - the ko in these two sentences is that mentioned in chap. iii. paras. 6 and 8 ; dork mūt = 'he formerly died,' and kō dork mut = 'the one that formerly died.' In other' words, again, the kō turns dork mūt into a substantive.

4. 'To be nearly' = lơk kābē, lơk, kŭs.

'T'his man is nearly mad = gwǒr-nĭ lơk kābē djī.

$$
\begin{aligned}
& =\text { gwơ-nĭ kě lơk (n)djī. } \\
& =\text { gwơ-nĭ kŭs kě (n)djī. }
\end{aligned}
$$

He is nearly dead = lŏk kābē mūt, kě lơk mūt, kŭs kĕ müt.

5. lă sheuk $=$ to be like in appearance, features; lă shăk = to be like, in disposition, manners, etc.

shěuk-chĭn-kěnĭ (mă) lă shăk (kě) sheưk-chǐn kě pŭ-nă.

His disposition is like nny father's.

6. 'To become' = mèt (which also is ' to go '), or' bär.

He has become $\operatorname{mad}=$ bär $\mathbf{d j i}$.

He has nearly become a blackguard $=$ chơk kābē mèt kǜl.

bār bri-chè $=$ H. 'ya zamma woni alu' = 'he has become something else' $=$ i.e. " he is not 'all there," " either physically or mentally.

7. ReLationships:-

$$
\text { pŭp = father. }
$$

nĭn $=$ mother.

gåiét = grandfather.

kĕkấ = grandmother.

yĕm $=$ son. yěm măt or ripp= a daughter'. găjét = a graundson.

kěkà = a granldaughter.

$\mathrm{mwŏl}=\mathrm{a}$ brother.

māl = a sister. 
Uniles.

pŭp kŭn = father's elder brother - (kŭn = big, important).

pŭp $10 \mathrm{k}=$ father's younger brother-(lok $=$ small $)$.

mwòl kě nǔn kŭn = mother's elder brother.

mwŏl kè ninn $10 \mathrm{k}=$ mother's younger brother.

Aunts.

māl kĕ pŭp kŭn = father's elder sister.

māl kě pŭp lǒk = father's younger sister.

māl kĕ nun kŭn = mother's elder sister.

māl kè nĭn lơk = mother's younger sister.

(mwǒl kě nĭn kĕ pŭp = mwŏl kĕ kěkấ= maternal greatuncle, and so our.)

kō kŭn kĕ nĭn=the eldel' one of the mother = either, ' mother's elder brother,' or ' mother's elder sister.'

kō lǒk kĕ nĭn=mother's younger brother, or younger sister.

8. The 'eldest son' is known as yěm kŭn or gō kŭn. The next child is kō-dí gō kŭn, and the next again is kō-d̆́ gō kă dün, which means 'the one following the middle one,' which the second, of the three, is.

The others are called by their names. The youngest of all, whether a boy or a girl, is known as k $\overline{\overline{\mathrm{eu}}} \mathrm{s}$.

The eldest daughter is ' rip kŭn'; the rest are called by their names.

A man will talk of his eldest brother as mwŏl-nū kŭn= 'our big brother'; of the other's as mwôl kŭn and their names, and of his youngest brother or sister as k $\overline{\overline{e u}} \mathbf{s}-f u n \bar{u}$; i.e. our youngest.

The mother will call her first born yĕm kă kēt, which is really 'child of virginity'-(e.l) kēt ğhü is a virgin goat).

9. In the Hill Angass there are a few slight differ- 
ences; small children call their father' 'dè' (see chrtp. xiii. para. 14); later on, pŭp.

Young boys call their mother by a word someled like our 'nor' pronounced short; young girls, 'n $\overline{a u}$,' and later' on, nĭn.

pŭp kŭn is, to all dē kŭn.

yěm kŭn is also yěm kă kēt.

kō dí gō kŭn is also, more generally; kö-(n)dăng gō(n)kŭn and kō dĭ gō kă dün is also, move generally', kō dĭ gō kă nēr. 'The dĭ in the last two lines can also take its other for'm, dhir = the H. wuri(n).

10. mŭ kăng kwăng kĕ pŭp= II. mun yamma vojen ubı = we are related on the father's sicle.

găjĕt -kěnĭ kwăng pŭp, gō Wŭssěllě ; kěká-kěnyí kě kwăng nĭn, măt Kăbĭr; pī kōdă kăng gō kě gō(n)Wŭssěllě kě gõ (n)Bwir kěshĕŭk = H. lialiansa na wojen uba, mutumen Wussèle ne; lialia-tasa ta ujon nuce matar. Kabir che; don wan-nan ya tara dengi da Wusselle duk ta Kabir = his grandfather, on his father's side, was a W'usselle man; his grandmother, on his mother's sicle, was a Kabir woman; because of this he claims kinship with both Wusselle and Kabir.

Note.-That gō = the Hausa ' dengi' as well as' 'man.'

ăn-kăng pŭp-kĕnĭ, kĕ nĭn băng (or kwăt) = H. na gammi uba da shi, da una kuma = I join his father and my mother too, i.e. we have the same father and mother.

pŭp-kěni mă kĕ nǐ-nă mă kăng pŭp=ubansa (su) da urvata, sulia gamma uba, i.e. his father and his mother had a common father.

Note how these expressions of relationship correspond exactly with the Hautsa idiom; kăng = H. gamma, and kwăng $=\mathrm{H}$. uoje.

mŭ lă shăk kĕ nyī $(=$ H. kumur-mu daia la shi $)=$ lit. we take a likeness with him, i.e. I am like him. 


\section{CHAP'TER XVI \\ PHRASES ANI) IDIONS}

1. H. la alinula liatu = kō-dăng dō dì-kā; or, nyī kĕ mě (chř) kā (dăk).

2. H. sheliara alinda ya $f i=$ tēr yī dĕl bì mă lì (or tăng); or, (ter) (tě) yì lă tăng kā.

3. H. ko daia, not even one $=\mathbf{k} \overline{0} . .$. .. găk kā, or kō..... găk lĭ-lǐss.

$\mathrm{He}$ is a poor man, he has not even one goat=nyī gwŏ-chōr, kō nyī kě ğhŭ (kō) găk kā.

4. lŏng $d \check{l}=$ he is fortunate, or prosperous.

5. kē ḡhā rìt=it is fortunate for you.

6. ă-fwŏt kwŏm-chĕ $k a ̄ ?=$ liave you not heard any news?

7. ăn-fwŏt bì-chĕ $k \bar{a}=I$ have heard nothing.

8. ă-tŏk shě̌k (n)gwā?= do you talk Hausa?

9. ă-fwŏt (n)gwā? = do you understand Hausa?

10. Pŭs-nǐ răng dō nyī ? = what time is it ?

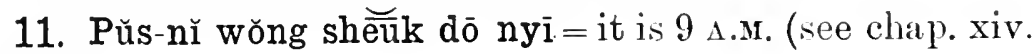
para. 4).

12. bŭt-nă děl kō-nĭ mă kĕ kō-pănă = I prefer this to that.

13. ă-lăp bĭssǒk-fănă = lit. accept my repentance, i.e. forgive me.

14. ă-wŭrn, tŏng sě-năn (sĕ gnăn) dŭng = hurry, I ain tirerl of waiting.

15. ji kĕ ăm tĭp gnăn=bring me pure (or clean) water (lit. black). 
16. (bě kě) mět băng = he lias allready gone.

17. ă-rōt bì dŭng = you like the thing very much; also, idiomatically for', 'you are playing the fool' (in an argument).

18. ăn-rōt bì kā, mŭ tŏk nyī kü̆t = l'm not playing the fool, let's tallk the matter to a finish (a friendly answer).

19. mŭ rōt shăk = we like eich other'; ind also, in continuation of 17 and $18=$ the affitir has enderl satisfactorily to us both.

20. ă-chĭn ă-yit $\mathrm{k}(\mathrm{w}) \bar{\partial} \mathrm{r}-\mathrm{d} \check{\mathrm{i}}=$ come, stop, this quarrelling.

21. ă-gorm răng kă kōl (kōlē) = what at roundıbout way of doing things! (contempt).

22. ă-chin kă kõl=you are quite in the wrong.

23. ğhā yē ă-chǐn shēuk, ă-mèt pó sheūk-fā; rather hard to translate $=\mathrm{H}$. kai ne lia yi maganar nan, lia tajfi bakin laifinka = you raised the question yourself, and have been found in the wrong; off with you!

24. ă-sếnăn (for ă-sě-gnăn) kă (or pī) tā =lit. you have eaten me for spite, i.e. you have convicted me because you hate me.

25. măt kătkăt, bě wǒk tơng gwïr $=$ it is better that a ball woman should remain single (see chap. xi. para. 4).

26. pār-chě bě ḡhü kě mět $g(y) \overline{1}$ kě kărbăk shìt kā =a goat will never go into the bush to seek a liyena (kărbăk) ( $g y \bar{i}=$ to seek).

27. shřt ně ă-năng bỉ kŭk, nyi kě bě kẳng yit ğhā = the grass which you call contemptible may one day pierce your eye (gha $=$ H. garelia $=$ the lative $)$.

28. yǐn kě tā, măt-dă cheung, bě tơng = the remetly for spite (or disobelience), if the woman is too much for you, ignore her (or "sit tight").

29. yěm măn wŭs kâ, kĕ nŭng nyì dăng = until a chilu is accustomed to the fire, it will burn him.

30. yīt kè pē, kě nē pī kā, bì kŭk (better bě kŭk) = if your (f.) eye sees nothing, it is worthless. 
31. mă chó mă=H. sulia (or alia) lierkashshe su.

32. sār kĕ pŭk, dăng ăn-bělm =I lick the hand with food in it.

33. sheũk tơk bě ă-sīt găk găk (or shídĭdĭ shídídí)= (compose yourielf and re-) tell your story bit by bit.

34. ă-găm dŭng dŭng bĕ lām gōl kè tŏk = if you explain so much, you will blind justice with your talk.

35. bì kĕ dūn, ăn-chăn (or chōl) bŭt-nā, kwăn-sōng $\mathbf{k} \overline{0}$-chè = the affair lıas got all mixed up, I will start again and make it clear.

36. ă-nē kwămtǒk, bě mănă lì tě kwămtăk=if you see so and so, don't say it is some one (or thing) else.

37. yĭt kĕ kơr děl kō ŭ-kör dŭng ŭ-kăng sār = not to fight is better thian fighting and making it up.

38. mă-(n)chĭt = mă-(n)kwăp = mă-(n)găk = they are exactly the same.

39. bì-nì dō-nì, bī-nì dō-nì =lit. "the thing is thus, the thing is thus' - said to exhort a man how to tell his complaint, or story.

40. ă-lí kĕ =come, speak out-(kē a particle $=$ H. $k a$ facli mana.

41. ké kĕ shĭt, bĕ ké kè yằng $=\mathrm{H}$. en ka yi mini lian karra, zan yi malia liain itache (lia sheliara liana furawa).

42. kē kĕ shwē kě tōn dŭng = the ear's of corn are very heavy, i.e. ripe.

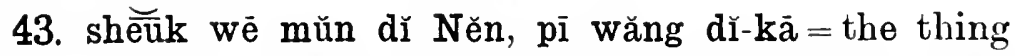
has fallen on us from God, there is no help for it-(wē mŭn = has come home on us).

44. mŭn kĕ pì wăng $k \bar{a}=$ we cannot help it, the thing is beyond our control.

45. bì kăt kĕ gō găk dō nĭ ā ? = do all these things belong to one man? (In wonder.)

46. mè pŭt $\overline{\mathrm{e}} ?=$ lit. what has come out $?=$ what has happened? 
47. mē pŭt wŭn $\bar{e} ?=$ what has happened to you?

48. bìdér kỏr $=$ the origin, eause, of the fight or quarrel.

49. ŭ-döm chřn-kĕnĭ = H. liu fara yinsa $=$ make a beginning.

50. ă-yāl Păngchěn kō ă-mět Ībī, pŭs kō-răng dăng ă-rū? $=$ if you start from Pankshin to go to Ibi, how many days is it before you arive? - i.e. how many days is it from Pankshin to Ibi?

51. ăn-yĭt nyī kā văng = l'll never leave it.

52. ğhā à-măn kā băng, dăng gnắn à? = you don't know, how should $\mathrm{I}$ ? = H. Lai ba lia sani serrai ha, beri ni.

53. dơk pŭtōm rōt kāa dăng kă shī bě rōt (or dăng bē bě röt kwăt) = at first he didn't like it, but now he does.

54. kě mět $\bar{a} ?=\mathrm{H}$. ya taṭi ? kě mět nchā $?=\mathrm{H}$. ya tatjii lie nan?

55. kă yŭl-nĭ fwăn kě yāl bĭdēr; à kà nchă ?=In this country the rain comes from the east; is it not so?

56. àng èt (for à gnèt) =it is so indeed $-(\bar{a}$ or àn $=$ thus, gnèt $=$ indeed $)$.

57. mă lĭ tă (for tě-ă) $\mathrm{j} \bar{i}=\mathrm{H}$. wei ka $: 0=$ you are told to come.

58. wē lí dĩ ? = who says this ?= H. en ji $v a$ ?

59. mă lěp kō-wē kă shĭt-chĭn-kěnĭ, kō yěm ní ?=H. ansa liou a a ailiinsa, shi yaro nan fa?

60. mă pün mwŏl-nă lở pǒ mǐnyī; gnăn dō, mă pün gnăn kā? =H. amba lianena ralionsa; ni de, la aca abani $b a$ ?

61. po minnyi $=\mathrm{H}$. bakin nasa, or rabonsa; pŏ kěnĭ $=\mathrm{H}$. balinsa.

Give me my share =ă-pün pŏ murnā gnăn = H. lia bani baliin naxa.

62. ăn-fwǒt mă lí tě lěŏk pó jīi = I heard them say that war is coming. 
63. fwŏt kă fwot fwot = r'umour= H. wai wai ne, or jita jita na ji.

64. brüng-nĭ kè wē ? pó lă kě dō = whose horse is this ? it is neighing.

65. mǐnă, ăm-ḡhā kěnǐ kã =it's mine; it's no business of yours.

66. yǐt lă kē kĕ bī kè gwŏ-chĕ ; or', yǐt chār kè bī kě gwŏ-chè = leave off looking (or, llon't look) after another's concerns.

67. ă-lă kē kè măḡhà (mīğhấ); or, ă-chār măḡháa găk= just look after your own.

68. păk mă tē kě ké kĕ brüng = some fell off their hor'ses.

69. păk mă sū; kō-wē dăp (or', wŭl) ār shǐ ké shĭ ké kõ bār kĕ chŏk-kĕnĭ = other's fled; each took a different road in order to sive his neck.

70. yǐt măt-kěnĭ-mă kě jěb mă sār kĕ gŏ-fwīn ; mă kă chĭn fwăn shĭ (or, kě) mă = he left his wife and children in the hands of the enemy; they macle slaves of them(fwăn also means ' rain,' and ' to untie').

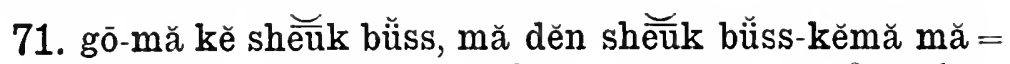
H. wadanda ke la laifi, asa masu $\underset{3}{(\mathrm{ma})}$ laifi-nsu $\underset{2}{2} \stackrel{2}{1} \underset{2}{1}$

72. gō kĕ chĭn kā, măntă ă-dèn nyī kăt=(continuation of 71) (but) the man who has not committed (an offence), put no (fault) on him.

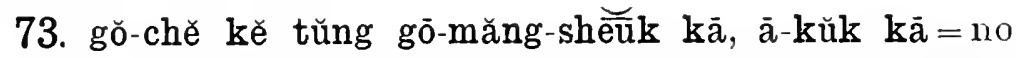
one will touch an innocent man, without cause (ā-kŭk kā) (= H. halika banza ba).

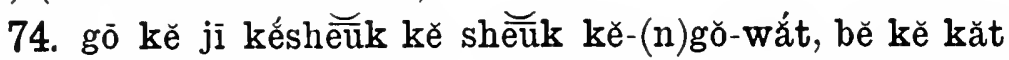
shī-kĕnı̆ $=$ every one who brings word of a thief, will receive his reward.

75. dăng gō kĕ ji kĕsheữk kĕ sheưk kĕ-(n)gŏ-fwīn-kĕní, pī jūr, măng shě̃uk kă, Něn-kĕnĭ kĕ yē nyī (ğhā idiomatically better than $n y \overline{1})=$ but whoever brings word of his 
enemy, on account of enry, and not for a fault, his God will seize him ('you,' better').

76. bŭshăng kẻ mwĕn kĕ gnăn= bowels ane wanılering with me, i.e. I am wandering with hunger.

77. ‘-lăp nyì kăk = 'look after it properly'; the answer' is :-

78. kě yāl pǒteūng à ? nē bě-nĭ băng = 'will it fly upwarts? See! it is actually here!'

79. Něn chěn kō wŏng kĕ pŭp-kĕnĭ mă chĕn dĭ-dhēr = Goel ordains that the spirit of his father should follow him (i.e. sustain, or back up, him).

80. ăn-lì kōl kā, ăn-lì kă sě gnēt = I will not talk roundabout, I will go straight to the point.

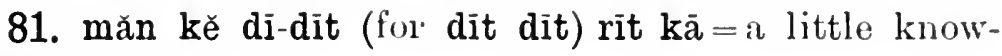
lelge is no use.

82. ăn-dūn jĕimăt-fănă $=I$ have spent (wasted) $m y^{\prime}$ money.

83. ki-dă küt dŭng = the fowl is fully developed.

84. gwǒlŏng Per găm sheūk büss kě (n)gwǒlőng Shǐwěr dondōn-dă = the king of Ampier once humiliated the king of Shiwer.

85. ă-dür sheưk-ghā kō ă-kăng gnăn = get rearly to meet me.

86. gwŏmī shř $(n) \operatorname{sh} \overline{1}=$ relationslip is a matter of visits.

87. păk mă tōt kĕmă kō mă lă jẹimăt=some pilwued themselves to get money.

88. ă-nē wŭs kă păp kĕ mwŏl-ḡhā, bě lă ăm kă mĭghảa =

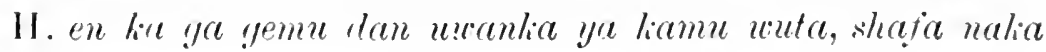
ruce.

89. mă chĭn (oI pŭt) kwăng děrī, kō mă děl à, kō mă kăt $\bar{a}$, ốhō ō = they are about 100 , whether more or less, loesn't matter.

90. mă jì kĕ bì zŭm, năng kĕnì = they came with a present to enquire of him. 
91. Něn dēm vwāl mŭn = Goil wald accident from us.

92. tī nyăng nyăng ā? (or, kăk tū-kěnǐ gnēt à ?) sār pŭt nyī à ?=dìl he kill him deliberately, or by accident? (sār pŭt = the hand came forth, i.e. of itself, inadvertently).

93. mwěn gŭm ānhā shẹ̌k büss dİ măt-mă=to go naked thus, is shameful to women.

94. ăn-kăt bì sĕ pi =I have got (found) something fearful (or', terr'ifying) (sě pi =lit. ' eats the world'). See page 109 , note 35 .

gŭm = naked.

kăt = get, find.

kăk = to intend, mean to

(it is also a particle).

$d \bar{u} n=$ to spoil, waste.

$\mathbf{k} \overline{\mathbf{l}}=\mathbf{a}$ fowl.

dür $=$ to alrange $=\mathrm{H}$.

gyara.

bŭshăng = bowels.

poteūng = heavens, sky.

chěn $=$ to follow.

bŭt = stomach, internal

emotions.

bǐssǒk = penitence.

wŭrn = haste, hurry.

küt $=$ to end, finish.

gorrm = to be crooked, alter

one's story.

tŭng = to touch.

(kă)kōl = not straightforward, of speech.

jūr $=$ H. lishi = envy,

hatred.

tā = spite, enry.

gwīr = unpaired. păp = a beard.

dēm = to ward off, protect

from.

nyăng nyăng = on purpose.

kărbăk = hyena.

kä̀ng = pierce.

chěung $=\mathrm{H} \cdot$ gagar $\alpha=$ to

be too much for.

chǒ = to kill thoroughly.

$\mathrm{r} \overline{\mathrm{u}}=$ arrive.

pŭk $=$ H. $m i a=$ soup.

$\operatorname{lām}=$ H. bata $=$ spoil.

chăn $=$ to recollect.

chōl = plan, device.

yằng = the guinea - cor'nstalk.

tōn = heavy.

wăng = getting out of the way, avoid, go round. büss = bad, wicked, dangerous.

pŭtōm = fresh, foremost.

chār = to covet.

fwin $=$ fight.

bār = to escape. 


\section{CHAP'IER XVII}

The stories in Angass are very similar to those of the Hausas, as these subjoined will show. They are apparently learnt off by heart, as, in telling one, a man will frequently be corrected as to a particular word, and if he hesitates or forgets, he will be helped by the others. Often, too, there occur phrases which appear to be archaic, as, taken out of the story and repeated by themselves, they are not understood, but when represented as being in a story, the answer is, 'Oh, then it is all right, for our father's told us it.' In the story itself they are intelligible by the context.

\section{THE HARE (Kåwon) ANI) THE PYTHON}

(Myĭrm)

Kăfwŏn mă ${ }^{1}$ yē sār ${ }^{2}$ kě myĭrm; mă mā ${ }^{3}$-mār, mă Zomo * (su) liama hanu-n mesa; su-na noma, su Hare they took hand of python; they farmmā ${ }^{3}$-mār, nyĭn tē mă; nyĭn ${ }^{4}$ tē mă, na noma, yunguva yafali (akan) su; (llu) yun!nra ya fuli su, farmed, hunger fell them; hunger fell them, kăfwŏn tě ${ }^{5}$ dūn ${ }^{C}$ sě mē ? lĭ kĕ kăfworn, 'ă-dăp zomo (ya che) su chimine? ya che ga zomo, "kadaulica hare (said) that they eat what? (he) said to hare 'take up chělě à-dèn mŭn kă wŭs'; chělě wơng; takuniu lia aje garemu a uruta'; tulimia ya yi rafi; pot place for us on the fire'; the pot warmed;

* The Hausa interlineation is only a more or less literal equivalent of the Angass above it. 
kăfwơn dăp dăng lěb chěle, tŭt,

como yadautia untzia yasa (a)tuliunia, yaliuna, hare lifted (python's) tail . put it in pot, it burnt,

yil ; myĭrm lĭ tě, 'ḡhā gŏ-nĬ! ḡhā ya yihayali; mesa yache, 'lai waman! liai it smoked; python said that 'you! this man! you

gō kŭk!' myĭrm bě kĕ dăng ; lěb mutum(en) ban::a!' mesa ya koma da wutria; ya sa (a) a man fool!' python came back with the tail; he put (it) chělě; mūr kĕ gām pfff $;^{7}$ dăng mă lě ès, ${ }^{S}$ tukunia: kisse ya chikta pfff; sacnan sulia auba gari pot; the fat filled up pfff; then they poured flour mă yăḳ ès mă lĕ dĭ $;^{9}$ mă chĕt gwìm; sulia ditia gari sukia zuba a-chiklit; sukia daffa gaya; they took up the flour they poured it in; they cooked gruel mă dăp, mă sě ; mă 4 dăp

mă sulice dautia, sulia chi; (da) sulia dauka sulia they lifted, they eat; (when) they had taken they had sĕ, kăfwŏn lǐ tě, ${ }^{10}$ 'gwŏ-nĭ, mūr ān்ā, chi, romo yache 'mutumen nan, yayitissehalitia, eaten the hare said that ' $\mathrm{Hi}$ ! this man; he is fat thus, (kw)ăn-chĭn rangē ?' dăng yāl, lì kěnī zan yi mine (lla shi)?' saanan ya tashi, ya che masa, what shall I do?' then he rose he said to him 'tăjī11 ŭ-mět mŭ sūp'; kăfwŏn tŭm sìt 'lia zo hu tafin mu wanka'; zomo ya sauli ya shig!ja ' come, you go let us wash'; the hare got down entered

nün ăm; wălăng, ${ }^{12}$ wălăng, wălăng, pŭt dār chilikin rua; splash, splash, splash, ya fitta ya tsaya into water; splash, splash, splash, he got out he waited
pǒ küng ;
pŭt
dār, myĭrm balin gefe; (da) ya fitta, ya tsaya, mesa brink of pool; (when) he got out he waited, the python 
lir tè

ya che,

said to him he was going

sīt nün gāk ; ${ }^{13}$ nyì mèt

zei taffi ghüzn dăng ;

fitsari tuliuna;

to pump ship; dŭm

ya je

\section{kăfwơn sū lèlē; dŭm}

ya shigga chilikin dedei; zomo ya gudu maza maza; ya je

he entered into the grass; the hare ran quickly; he went

dăp wŭs ;

dŭm ${ }^{4}$ dăp wŭs,

bě ji

ya raulia unta;

(da) ya je ya daulia wuta,

ya liomo

he took fire; (when) he went he took fire, he returned nyăng ${ }^{14}$ por-küng;

ya toya gefe;

lè chir

le chir le chir ; ya liewoiya, liewoiya, kewoiya; he fired the brink; he went round, and round and round;

my̌rm yāl

mesa ya tashi the python rose sit nün ăm-dhǐr ; 15 ya koma shigga rua; he entered into water ;

\section{dăng wŭs} saanan wutu then the fire sé pi ${ }^{50}$ kèt kext;

ya chi uri serrai serrai; eat up the place completely;

\section{$\mathrm{p} \overline{\mathbf{i}}$, \\ myirm pŭt}

wuri, mesa ya fitta wŭs ${ }^{4}$ sè

(da) uuta, ya chi

(when) the fire had eaten

sìt (nün) kŭrr; 16

ya shigga tolia;

the place, the python came out, he entered into the ashes;

\section{kăfworn ji nē}

zomo ya zo ya gani

the hare came he saw (he said) that 'my affair has died';

$\begin{array}{cc}\text { dăp } & \text { bì-kěnì } \\ \text { ya daulia } & \text { alinsa } \\ \text { he took up } & \text { his thing }\end{array}$

kē

\section{dèn yër ; ${ }^{20}$}

tè, 'bī-fănă ${ }^{1 i ̄}$ kè mūt';

ya che 'abina rei mutu'; lŭk ${ }^{18}$ kăjĭn; ${ }^{19}$

ya sa (a) ruzu; and threw it into his pouch ;

ya hau yaaje(chilikin) rumlu; ya beri (shi) awurin he mounted, he placed (it) in the granary; he left it (there)

kè tēr kō brtt băng ; ${ }^{21}$

zei livana don gari shi waye;

he slept until morning dawned; (when) morning dawned 


\section{yē yēr \\ ya liama rumbu \\ kē (n) yēr ${ }^{22}$ \\ nång \\ yа hau rumbu ya kirra}

he seized the granary he mounted the granary he called măt-kěnĭ, ' nă ${ }^{23}$-děngěl ! ${ }^{24}$ nă-děngěl! JI dăp chŭk ${ }^{25}$ matansa, 'na-dengel! na-dengel! ki dauka wukar his wife 'na-dengel! na-dengel!
bwăn,
yI pǖ̄̄ăn' ; 26
kabewa,
lii bani'; take up the knife,

(of) the vegetable, (and) give me'; she took up the knife

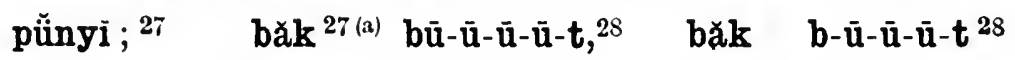
tabashi; ya yenke bu- $\bar{u} t, \quad$ ya yenke $\quad b \bar{u}-\bar{u}-t$ she gave him; he cut slash, he cut slash myirm yāl rā lả lā lả lā lă lā 29

mesa ya tashi rā lă la kè tēr po zei kwanta bakin the python arose rumbling he was lying (at) the door of

$\begin{array}{ccc}\text { yèr; } & \text { bě lir } & \text { 'tě, běl } \\ \text { rumbu; } & \text { ya koma che } & \text { 'ki fuda }\end{array}$
the granary; (the hare) said that 'bore into (the side of bŭt ō ō ō nă ${ }^{23}$ chèlkchè '; 31 ' ăn-dăp ${ }^{32}$ dè chikki-i-i na chelliche'; 'zan dauka kworiarka the granary) na chelkche'; 'shall I take up (and give) (you)
rān-fā ?
yi fwot tě běl bŭt õ ō ō,
da zāne?'
' $k i$ ji nache fuda chikki $i$, your striped bowl?' ' Listen, (I said) that bore into the side, nă děngèl' ;33 jěb mă sū mă jī běl bŭt na dengel'; yara suka gudu suka zo suka fuda chikkin na dengel'; his boys ran they came they bored into the yēr; kăfwon wŭl pŭt ḡhür jěb-mă rumbu; zomo ya bi yafitta ya kwashe yara granary; hare slipped out, he issued, he seized the boys,

mă sū ; myirm lì tě suka gudu; mesa ya che, 'jwèt jwèt jwèt';
they ran ; the python said that 'squeak, squeak, squeak'; 'jwēt ${ }^{34}$ jwēt jwèt'; ' jwèt jwèt jwēt' ; ueak, squeak, squeak'; 
kăt kăfwon

ya same romo (ya che)

he found the hare (he said)
' mă wŭl nưnēè, kè

'sun li ennu da

kărăng ${ }^{35}$-kènī-ma ?' yĕm lǐ tě 'wai! wai! wai!' kăfwŏn mutanensa?' yaro ya che 'wai! wai! wai!' zomo his men?'

tě, a boy said that 'oh! oh! oh!' the hare

ya che, said that

(n)yi rì'; ${ }^{36}$

lii nan';
' dār-nĭ kwăn-jī

'lii teaya num har en zo,

'wait here, until I come (kwăn) dăb

en claulie

I tiake thee

(from) here'; the python (said) that'squeak, squeak, squeak';

kăt kăfwòn;

' mă wŭl nùnē kĕ

ya same romo;

myirm lì tě

'jwèt jwēt jwēt';

mesa ya che

'jwèt jwèt juet'?

he found the hal'e

(ya che)

'sun bi enna

da

(he said) 'they are off where, with

kărăng ${ }^{35}$-kěnì-mă ?' kăfwŏn lì tě,

mutanensa?'

zomo yu che,

' Teūng-mă,

'Itatua, illan

his men?' the hare said that 'Trees, (if you are) my'

gwōonā, ${ }^{37}$

lin rlen!ri-na(ne),

relations,

' ŭ-tăp

'liun karrie

' you break bě ${ }^{38}$ lăngăn ; ${ }^{26}$

liu karloeni'; teūng-dă lì tě, itachen ya che, then take me' (safe) the tree said that yōm-fănă kwăt, $\quad \breve{u}$-bwăn lè-fănă kwăt' ; itache na liuma liun diba yaya-na liuma'; my branches too you pluck my fruit too';

kăfwŏn dě,,$^{39}$

'Yèkŭt, gwò-nā

zomo ya che, 'Loko, illan lia yi lengi

the hare (said) that ' $(O)$ Loko, (if you are) my relations

bě lăñăn pădō'; 40

ka karbeni liuma'; then take me up, again';
myIrrm bu- $\mathrm{u}-\mathrm{u}-\mathrm{u}-\mathrm{m}{ }^{41}$ mesa ya taffi bu-u-u-m the python (went) bum

\section{Yèkŭt dơk kăss ;}

Lolio ya yi shiru kaunvi; the Loko was silent merely kō yē kăfwŏn ; rei kama romo; to catch the hare; bè Yēkŭt

Lotio liuma then the Loko, 
lă dăp

ya rlaulie (shi)

took (hin) up, mèt kè nyī ;

ya tafii ala shi;
Yēkŭt

Lolio

the Loko dăp

ya dauka (mayana), took (speech), (he sail) 'kashak mot fim' the python died;

(Lolice ya che)

(the, Loko sail)

$$
\text { ăn-tū'; }
$$

na liasishe (shi)';

I have killed (him)';

tū dē ? ${ }^{44}$

kasshe shi?:

ăn-lı̆ tĕ

"na che

killed (him)?' 'I said that

' kwăn-yē ăn-lì ğhā

- illan na liama na gaya maka

' If I should take (and) say to you, 'à-chĭn ān dăng ă-

'lia yi liaka

lia

(How) did you do thus then you mơt fīm ';

"7ashal: mŏt fìm"',

"kashak mot fim", bè mūt à?'

zalia mutü?' would you die?'

\section{běntě, ${ }^{46}$ 'ă-lĕngăn, ăn-bě ${ }^{47}$ ăn-mŭt';}

ya che, 'idan lia che mani, zan koma mutu'; saanan he said that 'if you said (it) to me, I should die'; then

kafwŏn lĭ tě

zomo ya che

the hare said that 'kắshăk mŏt fīm ';

'liashak mot fim'; ' kashak mot fim'; yēkŭt mūt ;

Lolio ya mutu; the Loko died; dăng Yēkŭt mūt saanan Loko ya mutu then the Loko died,

küt dăk. ${ }^{51}$

ya liare.

dăng 


\section{NO'TES}

1 Note the idiomatic plural mă.

2 yē $\mathbf{s a} r=$ 'they caught hands'; i.e. 'they made a friendship'; but the expression connotes a reciprocal friendship; whatever one does for the other, the latter must return it, whether a day's work on a firm, or a meal, etc.

3 mă-mār for mār mār, intensive or emphatic reduplication.

4 A phrase repeated like this is best translated by our' participial forms, thus 'hunger fell on them; hunger having fallen on them, the hare said.'

5 tex is frequently used withont a verb 'to say,' ' to think,' etc., p. 33, para. 12.

6 If the hare himself said 'what shall we eat?' it would be ' $\mathrm{mu}$,' but as his words are being retold by the teller', the latter uses 'dūn', to show he is merely relating another's phrase; a sort of oratio obliqua, see p. 113, note 12 .

7 Onomatopœia.

$s$ ès intonation high $=\mathrm{H}$. 'gäri', 'flour'; intonation low $=$ 'egg.'

9 dí $=$ H. 'aucurin' (see chap. ix. para. 3 ); it could also be the accusative.

10 This is an aside. The hare is so struck with the fat or oil in the python's tail, that it rouses his desires. He plans to kill him.

11 tăjī for tè à-jī.

12 wălăng, or wălăk, onomatopœia.

13 gāḳ, a species of grass.

14 nŭng = 'to set fire to, in one place'; nyăng = 'to fire in many places.'

15 dhur = 'again' = H. 'ya lioma yi' (see chap. viii. para. 20). 
16 kŭrr = the blackened stumps of grass left after a fire.

17 'The hare aheally regards the python as his own.

Is lŭk = lit. ' to throw.'

1: kăjĭn = a bag made of webbing, with a shoulder strap, used for food in travelling; nearly like our haversack.

20 yēr or gyēr = the storehouse for grass or other goods; it has a round opening only at the top.

21 băng or măng = 'clear,' 'clean.'

22 The (n) merely euphonic.

23 nă (see chap. xi. para. 11) děn-gěl, the ' $g$ ' is hard.

24 děn-gěl = lit. ' a hunchback' ; nă-děn-gěl is the wife's niane.

25 chŭk is the 'household knife,' kept by the wife.

26 püngăn (see chap. iv. paras. 1 and 2 ); pün gnăn is also to be heard.

27 pünyi for pün nyī.

27 (a) băk = to cut with a knife.

28 Onomatopœia, the sound of the knife.

:9 The python unwinding himself.

30 The lengthened sound in shouting out.

31 chĕlkchě or chăkchě, 'fine,' ' upstanding'; 'năchělkchĕ' is another wife of the hare's, see notes 23 and 24 .

32 She doesn't hear him properly, and asks if he wants. a bowl to put the meat in.

33 He calls to 'nă-děngěl' again, as he imagines 'năchĕlkchĕ' has not heard. 'Thinking the python was dead, he was proceeding to cut him up, when suddenly the python uncurls, whereupon the zomo is frightened, and, being inside, wants a hole cut for him to escape.

34 Onomatopœia, the sound of the python's voice.

35 kărăng is 'mankind' as distinguished from beasts. The Angass apply it peculiarly to themselves: (= "where are they going with his people?')

${ }^{36}$ rĭ for $\mathrm{d} \check{1}=$ 'aururin,' see note 9 . 
${ }^{37} \mathrm{go}=$ ='a man'; also 'relative,' see ex. 86, p. 93 .

${ }^{38}$ This ' be' connotes an 'if' in the preceding sentence (chap. ix. para. 5).

39 dè for tè.

40 pắdō, a particle.

41 Onomatopœia.

42 Cabalistic words; no meaning to them.

${ }^{43}$ The Loko (H.) tree addresses the hare, which has taken refuge in it.

44 dè for dŕ é ? dr is the accusative 'him,' see chap. i. para. 12.

45 ba $=$ bè $ð$, see 38 (note).

46 běntè for be li tex; of frequent occurrence, the ' $n$ ' is euphonic.

47 an-bè, or simply 'bě,' see note 38 .

$48 \mathrm{f} \overline{\mathrm{i}}=$ ' to dry,' ' wither up.'

49 chokrr = the crackling sound of splitting wood drying up.

${ }_{50}$ See p. 109, note 35 .

51 dǎk, a particle. See p. 104, note 10 , and p. 114, note 15 .

The hare is treacherous, first to his friend the python, and secondly to the tree which rescued him, nevertheless roars of laughter greet the dénouement; - a significant commentary on their views on friendship and gratitude.

\section{THE PARTRIDGE (Tăkwără) AND \\ THE I)OG (Ăs)}

Tăkwără mă ${ }^{1}$ kè às mă yē sār $;^{2}$ mă

Pakara su da karre sulia liama hainu; suka The partridge they with the dog they caught hands; they

mèt mār kè tăkwără ;

taffi gona na pakara;

went (to) the farm of the partridge; dăng às må ${ }^{3}$ kana karre sun then the dog they 
mār mār ;

noma noma; dăng tăkwàră

liana paliara (tache) tè 'an-mět

'zan tafji

farm-farmed; then the partridge (said) i.e. 'I will go

àn-jīt ${ }^{4}$ shwē mŭn'; 5

dång às

en daffa mumu gakaiva';

liana liarre ya

tě 6 ' ō';

I will cook corn for us'; then the $\operatorname{dog}$ (said) i.e. ' $\mathrm{O}$ ';

dăng tåkwără mět jīt shwē ;

liana paliara ta taffi ta daffa yakaiua;

gyī pīl

ta nema tofa then the partridge went she cooked corn; she sought grass

kō kwok ' shwē dí ; ${ }^{8}$

don ta zuba daua aworin; in order to pour out the corn there;

' ji kō mū süm shwē';

'zo don mu suku dava'; 'come, that we may crunch corn'; then the dog came there ;

dăng kăt tăkwără

liana ya same paliara năng ăs, ta livrra karre, she called the dog,

dăng às jī dĭ; $\delta$ kana karre ya zo wuri;

lă shwē dün pīl ; 9 ta karba dawa chiklin tofa; then he found the partridge she took the corn in the grass;

\section{lì tě, ' mù sě dăk'; 10}

ta che 'mu chi mana'; dăng às lè

liana liarre ya sa

(she) said, i.e. 'let us eat, of course'; then the dog put his

\section{pơ-kĕnĭ dĭ ;}

bakinsa wuri : däng pìl yơng às nün lüs ;

kana tofa ta soke karre chiklin halshi; mouth there; then the grass pierced the dog in the tongue;

\section{ăs găm ${ }^{11}$ sĕ-kĕnĭ ; \\ karre ya soma chi-nsa;}

the dog commenced his eating; pīl yơng nyì

tofa ta solie shi nün lüs kwăt ;

chikkin hatshi kuma; in the tongue again;

\section{lì tě, ' Takwwără à-sě}

ya che 'paliara ki chi
shwē-fā,
ă-pŭt tū ${ }^{12}$-fànă';
gari-nli,
kin fitta kasshe-na';
tăkwărà
pakara

the grass pierced him your corn, you have come out my killing'; the partridge 
süm ${ }^{13}$ shwē-kënY ;

ta suliu gari-nta; dăng yāl mèt kō

liana sulia taslii sulia tajji don

crunched her corn ; then (they) rose (they) went in order mār mār ; ${ }^{7}$ dăng yāl ${ }^{19}$ mă wē ; ${ }^{14}$

dăng noma noma; liana suka tashi suka lioma gidda; liana to farm farm; then (they) rose they went home; then the

às tè, 'tō

liarre ya che 'to dog (said) i.e. 'Right! mi-nā ${ }^{15}$ pèt' ; 16 nau'a liuma'; tåkwără dēr mŭ mět pakara gobi mu tafji

Partridge, to-morrow let us go to my (farm)' ; next day they went to that of the dog indeed;

\section{dăng pŭs wŏng ;}

dăng ăs li tăkwără

saanan rana ta yi zafi; saanan karre ya che (ma) pakara then the sun got hot; then the dog said to the partridge,

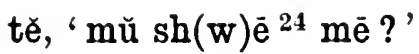

\section{dăng tăkwără}

' ğhā dō

'mu sha me?' saanan paliara (ta che) 'liai ne i.e. 'we shall eat what?' then the partridge (said) ' you are gwơ ${ }^{18}$-lŭ mār';

tåkwără lè ār ;

dăng

mai gona'; pakara ta liama hainya; saanan the farm owner'; the partridge took the road; then the

\section{ăs tě, 'mĕt ${ }^{19} \mathrm{kwăn}$-tŭ ${ }^{20}$ wēr mŭn'; 5}

dăng

karre ya che 'zan tafji en dama mumu kunu'; saanan dog (said) i.e. 'I will go in order' to mix gruel for us'; then the

ăs tŭ wēr dí; liarre ya clama liunu vuri; dog mixed gruel there;

dō ${ }^{31}$ kă lēr ${ }^{21}$ pē ; ${ }^{22}$ ya zulua a-farin ja; dăng as tŭ wēr, liarre ya dama liumu, then the dog mixed gruel,

năng tăkăbără 'tă ${ }^{23}-\mathrm{jì}$
ya liirra paliara 'ki zo
he poured on a flat rock; he called the partridge i.e. 'come,

kō-mū shwēe' ; ${ }^{2 \cdot 1}$

clon mu sha'; that we may eat';

\section{năng tăkwără}

ya licira paliara he called the partridge, mă dōm ${ }^{20(\mathrm{a})}$ sulia fara they began 
shwè kè wèr;

sha-n kunu; dång tăkwără găm ${ }^{25}$ shwē-kěnı̆ ; saanan paliara ta fara sha tasa; eating of the gruel ; then the partridge began her drinking;

tě ${ }^{26}$ găm shwē-kĕnì, da ta fara sha tasa, when she began her drinking; bě kwős ${ }^{2 i}$ p 0 -kěnı

ta sara baliinta

she struck her beak

kă lēr; pó-kěnĭ lüm ; ${ }^{28} \quad$ às mwăk ${ }^{29}$ wēr-kěnĭ

a-duchi; bakinta ya tonkashe ; lare ya shainye kunu-nsa on the stone; her beak bent; the dog lapped up his gruel

kět ${ }^{30}$ kět; dăng tăkwără tě, ' à-dō ${ }^{31}$ wēr kă serrai serrai; $\quad$ saanan pakara ta che "domi lia zuba completely; then the partridge (said) i.e. ' why did you pour

lēr pimē ?' dăng ăs tě, 'dơk ă-mět
liunu a-pa?' saanan liare ya che, 'da kin taffi on the stone?' then the dog (said) i.e. 'before, you went to

lŭ mär ${ }^{18}$-fā, à-jīt shwē, ă-dō nün pīl gonanki, liin daffa dawa, kin zuba chikkin tofa your farmhouse, you cooked corn, you spread it in the grass

pìmë ?

dominene?

why? dơk pŏ-nā kō ${ }^{32}$ mŭ-ḡhā-dă.' 33

dā balki-na liaman naki-n (yanzu).'

Tăkwără lĭ tĕ, 'ăn-măn těnè ${ }^{24}$ ă-sě ${ }^{35}$ pī nün pil kā,

Paliara ta che, 'ban sani ka chi abu chilkin tofa ba, the Partridge said, i.e. 'I knew not, i.e. you eat in the grass,

dăng ${ }^{36}$ ă-jī

saanan ka $\% 0$

\section{à-dō wēr kă lēr těnĕ ${ }^{37}$ pǒ-nă nyī} ka zuba kunu a-pa don bakina ya then you come you pour gruel on a stone, i.e. that my beak

lūm dā ? ${ }^{3 s}$

tonkashe nan la?

bent here, eh? dăng ${ }^{36}$ mŭ rĭb shër dì ' ; ${ }^{38}$ suanan mu rabbu abokata awuri'; then let us break friendship here';

ăs-dă 'mŭ rĭb, kĕ'; 39 ăs-dă lì tè, 'à-nē liarren, 'mu rabbu, mana'; karren ya che, 'da ba li the dog, 'let us divide, then' ' the dog (said) i.e. 'If you had 
yìl dūn ${ }^{40}$ kà,

gani dunia ta bache ba, bě mŭ ${ }^{41}$ kăng

da mun gammu not seen that the world is spoilt, then should we have joined

kĕ ğhā?

da lie? kă pī kwăt bě ăn-yē ḡhā kā ?' a-uurin farauta ba zan kama lic ba?' with you? in the place of hunting would I not seize you?'

dăng tăkwără lì lē,

saanan pakara ta che
' ā yē! 42 bì-dă 43 ā yā?

'asse! alin halika ne? then the partridge said, i.e. 'Indeed! is the matter' so?

be ${ }^{44}$ chīl-chè

kuma idan woni mili. lě ăs pơ bēs,

again if a splinter seized a $\log$ on the point of the knee,

dăng tǎkwără kwơs ${ }^{27}$ chīl-dā ?'

liana paliara ta sara milii nan?'

yāl bī-kènì

ta tashi abinta does not the partridge peck out the splinter?' She flew off, kè lāng teüng ; às dār kăk ${ }^{4 i}$ kăk tě ${ }^{46}$ kè zata hau itache: liare ya tsaya hav har don za ta to mount a tree; the dog waited patiently i.e. she will

tŭm;

sapka ; descend ; nē nyř kā;

lai gau-ta ba ; he did not see her'; düm lr gworlőng-kĕmă ; ${ }^{47}$ ya je ya faula ma serilinsu; ăs mèt wē; karre ya tafii gidda; the dog went home;

' illan ku same paliara he went he said to their king; "if you find the partridge

\section{bū ${ }^{48}$-yēe'; dång gworlơng tè}

' bèl kā-fā, 49 liu kama (ta)'; saanan serilii (ya che) 'ba vayo-ba naka, seize (her)'; then the king (said) i.e. ' your senselessness,

kā ${ }^{50}$ bē en ba halika ba, wă ${ }^{51}$-chĕ kĕ chĭn shēr kĕ tăkwără ? wanene zei yi abota da paliara? if it were not so, who would make friends with a partididge?

bidēr keüt dō dă';

guzun (magana) ya liare lie nan ;' the origin (of the matter) is quite finished'; thus then $\bar{a}^{52}$ dàng saanan halika 
as ma met kwat

(ne) (idan) karre su taffi farauta,

(if) dogs go to hunt, mă kăt tăkwără, mă su same paliara, su yē dY. ${ }^{53}$

liamata. seize her.

\section{NOTES}

1 Note the idliom, use of plural. See p. 101, notes 1 and 2.

2 See note 2 of 'The Hare and the Python,' above.

3 The farm is the partridge's, so directly another is mentioned as at work on it, it connotes the plural, the owner naturally working too.

4 jit $s h w \bar{e}=$ to cook unground corn $=\mathrm{H}$. gakaizwa.

5 mŭn = the dative, ' for us.'

' tex, often used without the verb, 'to say' = ' that is,' or 'that is to say.'

7 kõ kwork or kō nyī kwǒk = the subjunctive.

8 dí is pronounced with a very short ' $\mathrm{I}$,' which is sometimes unnoticeable and=almost 'shwē-d.' See note 38, and p. 120 , note 28 .

9 A very spiky grass.

10 dak, a particle. See p. 100 , note 51.

11 găm, here = 'to begin'; it also = the H. 'chikka,' and ' nuna' = 'to fill' and 'to show.'

12 'you have brought out my killing,' i.e. 'you are minded to kill me,' or 'you have come out to kill me.'

13 süm = to crunch in the mouth.

14 wè, means, 'to return home.'

$15 \mathrm{~m} \check{\mathrm{I}}-\mathrm{na}=$ ' mine,' i.e. ' $\mathrm{my}$ farm '; this is the return for the work done to-day. See note 2.

16 pèt = a particle.

$17 \mathrm{ma}=\mathrm{kec}$, prep. ' of '; but 'kě' her'e is ambiguous, as ' mă mět kè ăs' = 'they went with the dog' (see chap. ix. para. 1), whereas here the meaning is 'they went (to the farm) of the dog.' See p. 21, para. 9. 
18 lú-már = 'a farm hut' -all the Angass have huts on their distant farms, either to rest in, to shelter in from the rain, or to keep watch; gwo-lŭ mấr is, 'the owner' of such a hut,' and therefore 'the host,' on such an occasion as this.

19 The person of met is decided by that of the following verb, when two are in juxtaposition like this; contrary to our custom where the person is omitted in the second verb, e.g. 'they got up and ${ }_{\wedge}$ went;' 'I will go and ${ }_{\wedge}$ prepare gruel.'

20 tŭ = ' to stir,' ' mix.'

20(a) See p. 120, note 31 .

21 lēr = the Hausa ' $p \bar{\imath}$ ' = a broad, clean, flat rock.

${ }^{22} \mathrm{pe}=$ white.

${ }^{23}$ tă-jī, for tè ă-jì.

24 Note that shwè or' shē means both 'guinea corn,' and ' to drink.'

${ }^{25}$ Note that găm = dōm of the preceding sentence; see notes 11 and $20^{\text {(a) }}$.

26 ter here = the Hausa ' $d \check{a}$ ' = ' when.'

$27 \mathrm{kw} \delta \mathrm{s}=$ ' to peck,' of birds, and also 'to strike,' of an axe.

${ }^{28} \operatorname{lu} \mathrm{m}=$ ' to bend,' or ' get bent.'

29 mwăk = 'to lap up' of dogs, etc.; also 'to lick' of men.

30 kext kět, emphatic particle; nearly always used reduplicated.

${ }^{31} \mathrm{~d} \overline{0}=$ to pour out.

32 See chap. xv. para. 1.

33 mŭ-ğhấ-d $=$ (like) 'the yours,' i.e. (like) yours is now.

34 tènè, a lengthened for'm of 'tè' '='I dill not know, that is to say, that' = our ' I did not realise that.'

${ }^{35} \mathrm{p} \overline{\mathrm{i}}=$ lit. 'a place' $=\mathrm{H}$. wuri ; but it is also used in a vague impersonal way and=' every where,' ' every one,' and also for the world in general ; and is also=our slang 'all over the place' or 'all over the shop,' see p. 103, note 50 . 
36 Also frequently means ' but,' which is its signification here (chap. ix. para. 7).

37 těně, best translated here 'so that' (my beak has got bent). See note 34 .

38 dā? for dí à? See p. 120, note 28, and p. 103, note 44 .

${ }^{39}$ kĕ, a particle. See ex. 40 , p. 90.

40 dūn='to spoil,' or 'get spoilt.' 'If you had not known that the world had gone to the bad, should I have joined in with you?'

41 Note the pl. idiom, and see translation, note 40 .

42 à yē ! an exclamation $=H$. $\breve{s} s \bar{e}$ !

43 bì-dă à yā ? = 'Is the thing thus, eh ?'

44 This sentence may refer to what happened, or may perhaps be a continuation of the speech of the 'pakara,' explaining how she in her turn can be of real service to the log; that is, that the friendship is not all one-sided, as the dog makes out.

45 kăk kăk, a reduplicated particle. 'The dog waited and waited.'

46 tĕ, a particle, or perhaps the tě of note 34 .

47 Note, again, the plural, where we say ' told his chief.'

48 b̄ yē for be $\breve{u}-y \bar{e}=$ " if you find the partridge; catch her.' Note 38, 'The Hare and the Python.'

49 bèl = ' sense,' bèl kā= 'senseless' (chap. v. para. 6)note the position of the possessive pronoun, běl kā-fā, not bèl-fā kā.

50 kā bè, the kā for kā $\bar{a}=$ 'not thus.' An idiomatic transposition of kā which, as a rule, is at the end of the phrase (chap. ii. 10).

51 wă-chě ? ="who ever' (would make friends with a partridge?)

52 dang, as a rule, commences the sentence, but here follows ' $\overline{\mathrm{a}}$ ' for euphony.

53 dì the acc., mă yē nyī = 'let them catch for him.' See note 44, 'The Hare and the Python.' 
THE KURKUTAN (Kŭrkŭtấn) AND THE CROWN BIRD (Rwāt)

Kŭrkătắn ${ }^{1}$ mă kè Rwāt mă tẹ leăng ${ }^{2}$ yāl ; dăng mă

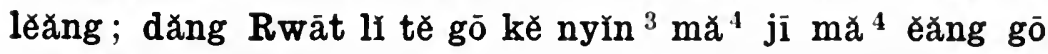
nyin kā; dăng mă yāl mă mèt dĩ ; dăng rwāt dưm ny̆n ; dăng mă bě mă kē ; ${ }^{5}$ dăng Rwāt ji ěăng kŭrkătắn dri. ${ }^{6}$

\section{NOT'ES}

1 Kŭrkŭtắn = the name of a bird.

2 ' debating,' lěăng or lắng.

3 nyin, voice, or intonation high $=$ 'hunger'; intonation low $=$ 'tired'; here it is the latter.

4 'The impersonal $=\mathrm{H}$. ' azo abia.'

${ }^{5}$ Lit. "they returned, they topped' $=$ 'they reached home'; cf. H. ' ya kai (gidla),' where ' lici' = reached.

6 Not the acc. (see note 44, 'Hare and the Python'), otherwise it would precede the dative; here merely the particle. See p. 120 , note 28.

\section{THE TORTOISE (Kăkúr) ${ }^{1}$ AND THE HARE (Kăfworn)}

Mà lě ${ }^{2}$ kèt $^{3}$ mār; mă sě gwìm ; ${ }^{4}$ mă yāl mă mèt sūp ; må tè, 'mŭ chār ${ }^{5}$ lās' ; ${ }^{6}$ kăfwơn lì tě, ' ăn-mwăt ğhā, kăkứr, pŭtōm'; kăfwơn mět lām kē kō mwăt' kăkúr ; dăng pŭt tōm dí; kăkŭr pŭt sū dí; tě, ' $d e \bar{r}{ }^{13} d \overline{d u}^{8}$ lăng ${ }^{9}$ àm kě gwār ${ }^{8(a)}$ kā'; kăkứr sū, jī kě tákănă; ${ }^{10}$ mă pŭt $m(w)$ ă răng ${ }^{11}$ dō dă, yē ${ }^{12}$ keutut.

\section{NOTES}

1 kăkúr or kŭr = the tortoise; güt = the land tortoise.

$2 \mathrm{le}=$ H. 'zul'a.'

${ }^{3}$ kèt $=\mathrm{H}$. ' iyaka' = boundary; $c f . \mathrm{H}$. leetare, to cross.

${ }^{4}$ gwim $=$ H. 'gaya' or 'gaiya.'

5 chār = H. 'bŭga'; chār păs = 'to shoot an arrow.' 
¿ lās=H. Léchchù = the turning over in the water and striking with the leg; chär lās = to indulge in the pastime of this striking.

' ko mwàt=the subjunctive; "he dived in order to strike.'

$8 \mathrm{~d} \overline{\mathrm{u}}$, a sort of oratio olliqua; "he said that to-morrow they.' See p. 101, note 6 , and notes 3,5 , and 8 in 'The Hare goes Hunting.'

s(a) gwār = 'that . . . you'; see ' dū' above.

9 lăng = to spor't (in the water', on horseback, etc.).

10 kè tăkănă= 'not again'; another form is zākā; jī kā = 'he did not come'; ji kè tắkănă, or' ji zākā= 'he did not come again.'

11 răng = 'to separate' ; 'to scatter.'

12 yē =H. ya kama, idiomatic ending=lit. 'ya kama (ya) liare.'

$13 \mathrm{dēr}=$ lit. ' to-morrow', but is also used for 'for the future.'

\section{THE HARE GOES HUNTING (Kăfwŏn pŭt kwăt)}

Kăfworn mět kwăt; düm kăt būp, mă pŏ ${ }^{1}$ tăm kĕ ${ }^{1}$

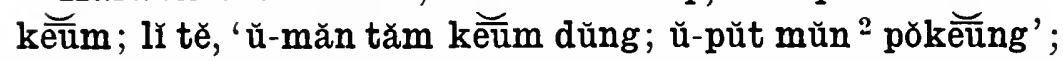
mă pŭt dĭ; dăng lĭ těně ' pŭs wơng dūng'; lì tě, 'gyī 3 mwăt ${ }^{4}$ pŭk nywē'; ${ }^{5}$ dăng mă tăm keưm dün pŭk; dăng bwot ${ }^{6}$ wŭs kă kē mă; ${ }^{7}$ dăng wŭs sě mă dĭ; dăng mŭlút jī kăt nyī; lì tě, ' $g$ wā ${ }^{8}$ kăfwŏn gwār ${ }^{9}$ bŭn kō ${ }^{10}$ kwăn ${ }^{11}$ kwăn kě būp gwār ${ }^{9}$ pün gyī'; ${ }^{12}$ dăng kăfwơn tě, 'ē ē, à-yitt kō kwăn kwăn, kwăn-sě dě, kwăn-yāl bě ăn-găm răn dèl mì-ğhấ ḡhā; 13 ă-nē tōm, bě gnăn ăn-răn nyī; dōn ${ }^{14}$ gnăn tě, kwăn-răn ghā dě '; ${ }^{17}$ dăng mŭlūt tĕ, ' mŭ sĕ būp-fŭnū'; dăng mă sě dì; dăng mŭlūt tě, 'tō, ăn-mět kwă-răn gnăn dăk, ${ }^{15}$ kăfwơn' '; dăng kăfwŏn tĕ, 'a!' dăng mă mět dí, mă düm mă kăt teūng; dăng kăfwŏn tě, ' mŭlūt, ă-jì kwăn-răn ghā dăk' ; ${ }^{15}$ dăng mŭlūt jī dí; tě, 'ă-jī tōm ${ }^{16}$ těŭng kwăn-răn ğhā dě'; ${ }^{17}$ dăng mǔlūt jì dí; 
ji kŭk ${ }^{18}$ shr teūng; dăng kăfwơn dăp tă̆ng $\mathrm{k}(\mathrm{w}) \overline{0}$ răn ${ }^{19}$ mŭlūt dr ; mŭlūt tè, ' $\bar{a}-\bar{a}-\bar{a}$ !' dăng lì tè, ' măně ${ }^{20}$ gwār ${ }^{9}$ tŭng ${ }^{21}$ shĕk, răn kě dūn; dăng mŭlūt dơk; ${ }^{22}$ dăng kăfworn dăp dăm, ${ }^{23}$ kō mwăt mŭlūt (n)kē ; mŭlūt mūt ; năng măt-kěnì-mă, ně, ${ }^{2 \dagger}$ gyị $^{3}$ tŭ bī rām; ${ }^{25}$ kō măt-mă jì dŕ, kō mă dăp mŭlūt-ní; mă mă ${ }^{26}$ wē kō mă düm mă sě.

\section{NO'TES}

1 'The 'Continuous' Tense, chap. vii. para. 11.

2 Even if there were only one man in the water, and one on the bank, the latter would say to the former 'a-pŭt mŭn'; see notes on this idiomatic use of the plural in former stories.

${ }^{3}$ gyi, the oratio olliqua (he said), ' that he'; see note 12.

4 mwăt = lit. ' to beat,' mwat pŭk = H. 'ya yi buka' = build a hut.

${ }^{5}$ nywe esame as note 3 , nywe being the 2 nd per. pl. "That he would build a "buka" for them (you)'; $\operatorname{dŭf}(\dot{\mathrm{n}})=$ 3rd per. pl. See 'Hare and the Python,' note 6.

6 bwrt, here $=$ H. sa, 'to place'; it also means 'to release.'

' ma is the dative $=$ H. ' ya sa masu wuta a-kai'; ' ya sa wuta alkainsu' would be 'bwơt wŭs kă kē kè-mă.'

${ }^{8} \mathrm{gwa}=$ oratio obliqua, 2nd per. sing. = (that) 'thou,' note 12 .

${ }^{9}$ gwär is a more general form of gwà. See note 8 .

${ }^{10}$ ko makes a substantive of the adjective kwan kwăn. See chap. v. para. 8 , and chap. iii. para. 8 .

" kwann kwann, another form of kŭn kŭn=H. mainya mainya.

12 gyi, see note 3. Here it is the dative. Note how mixed the persons become, i.e. 'he said, that you, hare, that you pick out the big ones of the fish, that you give to him,' but remember it is not the oratio obliqua proper, but a storyteller, telling his story of what was said by other's. 
13 ghā, the dative. A verb taking two objects puts the object in the dative last, however far off that may be, after the accusative and all its dependent sentences or attributes.

14 dōn $=\mathbf{d} \not \mathbf{k}=$ 'formerly,' 'some time ago'; dōndōn = yesterday.

$15 \mathrm{dak}$, an enclitic.

16 tōm = 'the foot,' ' the bottom,' 'foundation.'

ii dě, a for'm for dr.

18 kük = 'to lie close alongside,' or 'along'; also our slang, 'chock-a-block.'

19 răn means here 'to tie'; in the several appearances before răn is a different word, meaning 'a stripe,' 'a line,' 'a pattern.'

20 mănè is the form of măn or măntă, used with the oblique forms of the per. pronouns; in this case gwār= ' that let you not.'

21 tŭng=lit. ' to touch'; tŭng sheuk $\mathbf{c}=$ ' to move the body,' ' wriggle,' etc.

$22 \mathbf{d} \mathbf{k} \mathbf{k}=$ 'to keep silence,' or ' keep quiet,' of movement.

$23 \mathrm{dăm}=$ 'a stick.'

24 ně = a shortened form of těně. See note 34, 'Partridge and the Dog.'

25 rām = 'splendour,' ' glory'; bī rām, 'anything splendid,' 'glorious,' ' magnificent,' etc.

26 mă mă wě = the reduplicated plural of mă wě = 'they all went home.'

\section{THE GUINEA FOWL (Tōm) AND THE HARE (Kăfwŏn)}

Tōm ${ }^{1}$ săk $^{2}$ mār; dăng kăfworn yāl lě ${ }^{3}$-mār-kĕnĭ; dăng yāl wŭl kī; düm kăt shwē kè töm; kăt ${ }^{5}$ shwē, nē shwē rīt yit-kĕnı̆; nē ār dřkā; dăng sitt ${ }^{6}$ chēn, ${ }^{7} \mathbf{k}(w) \bar{o}$ mā $(r){ }^{8}$ ār shř shēuk ; ${ }^{9}$ tōm kĕ yāl, mět lě-mār-kěnr, yāl ${ }^{10}$ kă

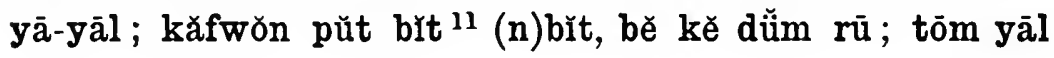


jī ; tōm jī, kăt kăfwơn kě dơm mār; tōm tě, 'wā kě dōm ${ }^{12}$ lě-mār gyī ?' ${ }^{13}$ kăfwoon tě, 'lè-mār kě gwār ${ }^{13}$ $\bar{a}$ ?' dăng tōm těe, ' $\bar{e}$, ně mĭgyī'; ${ }^{13}$ kăfworn tě, 'ār-fā nē, ${ }^{14}$ tōm?' Tōm tè, 'gyì ${ }^{13}$ yāl, mì-gyī ${ }^{13}$ pơteūng'; dăng kăfwơn tě, 'ă-chăn ${ }^{15} \mathrm{kwőlm,} \mathrm{ğhā} \mathrm{tōm,} \mathrm{mār} \mathrm{mǔnā,}$ ă-nē ār-fănă dō ${ }^{16}$ vitt ${ }^{17}$ nř'; dăng kăfworn chěp ${ }^{18}$ pó tōm, kō tōm kürr-mūt, ${ }^{19}$ kō bẻ kě mār, yìt nyī ; ${ }^{20}$ kăfwơn mār-dă kō bě kě mì-nyì dōn-tī yĭt dì ; ${ }^{21}{ }^{2}{ }^{22}$ dāng, tōm kür-mūt dě, kõ ${ }^{23}$ bě, yìt mï-nyī kăfworn; ; ${ }^{21}$ kō $^{23}$ kě mwěn, kě sě shwẽ kě gŭrm-mă dĭ.

\section{NO'TES}

1 Töm= 'guinea fowl'; it also= 'blood' and 'bottom.' See 'The Hare Goes Hunting,' note 16, and the 'Tortoise and the Hare.'

${ }^{2}$ săk = If. sara, ' to cut off trees, bush,' etc.

${ }^{3} \mathrm{ma} \mathbf{r}=$ 'to farm'; le-mar $=\mathrm{H}$. zulus gona, and = "the farm' itself.

${ }^{\prime} \mathrm{ki}=$ ' 'unf:trmed, wild bush'; it also = 'a fowl.'

5 See note 4, 'The Hare and the Python.'

${ }^{6}$ sit $=$ H. fitcla ; sit $=$ H. 'shigga,' and 'chinilit' or' 'sayer.'

' $\operatorname{chēn}=$ H. fatcinya. In Plain Angass it is also userl for the 'Kenti'; only marle at Kantanna in the Kamna district, a small hoe.

8 Pronounced mā for euphony.

9 See chap. i. para. 12.

10 See chap. viii. para. 16 ; yā-yāl for yāl yāl, chàp. $x$. par'a. 25.

$11=$ H. da sasafe; (n) enphonic.

12 dom here = Il. tsumpene, 'to bend down'; it also= 'to begin.'

13 Oratio obliqua. See 'The Hare Goes Hunting,' note 12.

14 nē $?=$ nǏnē $?=11$. enna ? = 'where?'

15 See chap. xi. $5(a),(b)$, and note. 
16 For dō dā= H. lie nan. See chap. i. para. 18.

17 vit ; very long ' $\bar{i}$ ' = 'straight along.'

18 chěp po pó ='to bully'; chĕp pr tơm = 'bullied the guinea fowl.'

19 kür = fear ; kür-mūt = to be deadly afraid.

$\therefore$ The dative. See note 21.

21 The accusative. See note 20 ; and chap. 1, para. 5.

22 See note 52, 'The Partridge and the Dog.'

23 The subjunctive.

24 The dative.

THE MONKEY (Jǒli), THE LEOPARD (Mŭlūt), THE HARE (Kăfwŏn), AND THE TORTOISE (Kăkŭr)

Jŏlī ${ }^{1}$ pŭt mwěn; düm kăt mŭlút mă lěǒk kě kēp $;^{2}$ mulút ${ }^{3}$ mă lěǒk kě kēp-mă, bì pyār ${ }^{4}$ pyār kěnĭ dă dăk, kō sìt teūng gwōr ; jŏlì jì kăt mŭlūt teūng gwōr; dăng mŭlūt lì kě jŏlī tě, ' $K \bar{a},{ }^{6}$ ă-s̆̌t ${ }^{7}$ gnăn dăng dăk'; dăng lì tě, ' mă ${ }^{8}$ sǐt ğhā, mŭlūt, bă ${ }^{9}$-yāl bă ${ }^{9}$-y̌tt gnăn dā ?' lì tě, 'ăn-yāl, ăn-y̌̆t ğhā dě'; dăng jŏlī sĭt nyī, $\mathbf{k}(\mathbf{w}) \bar{o}$ pŭt dĩ ; kăfwơn $j \overline{1}$, kăt mă ; dăng lĭ tě 'mē kě nywē ${ }^{10}$ dăng nywē ${ }^{10}$ körr è ?' Dăng jŏlì tě, 'dōn ${ }^{11}$ teūng kām kěnr' ; dăng kăfwŏn tě, ' gyı̃ ${ }^{10}$ lĭ nywē, kō gyĩ ${ }^{10}$ sheūk tŏk kě nywē'; kō kăfwŏn pŏ ${ }^{12}$ tǒk kĕ shēuk mwă, bě mŭlūt lă jŏlī yē-(n)kē, sĭt mwăt; ${ }^{13}$ kăfwơn yāl, wăp ! ${ }^{14}$ lă ğhk dăp, bě mwăt mŭlūt (n)kē, pǒk! ${ }^{15}$ kăfwŏn nē mwăt mŭlūt, yāl, sũ, kwō düm lām; mŭlūt pŏ ${ }^{12}$ gyī kěnĭ; kăfwǒn nē mŭlūt pŏ gyī kěnĭ, düm fĭl ${ }^{10}$ tắng lēlē, kō bāt ${ }^{1 i}$ shī dĩ ; dăng bě jĩ dĩ ${ }^{18}$ mŭlūt; lǐ tě ' gwār ${ }^{10}$ kĕ gyĩ mē, mǔlūt?' Dăng mŭlūt tě 'păk kě nywē dă ${ }^{19}$ dō dă kā?' dăng tě, 'mă chĭn mē ğhā?' dăng tě, ' ğhā yā ${ }^{21}$ mădăn ${ }^{20}$ dă dō ${ }^{19}$ nĭ kā?' 'tă nē gnăn pǒ lě shī-fănă dō nǐ ntĩ'; lǐ tě, ' $g$ wār kŭn, bě ă-chĭn mē, dăng jěb ${ }^{22}$ mă mă mwăt ğhā dē?' 'Păk-fū dă dō nǐ gnēt,' dăng yē 
kăfwơn dă dŕ; dăng lì tě, ' ghā kŭn, bă-dăp kworm-fănă, ${ }^{23}$ ă-děn pănă, dăng kwă-măn ${ }^{24}$ sě dÍ'; dăng dăp kăfwơnn, kě kworm-dă kěsheưk, lŭk ${ }^{25}$ pănă, těně, 'gyì dăp kwomdă'; dăng dăp kăfwơn lŭk kě kwơm-dă kěsheǔk ; ${ }^{25}$ kăfworn yāl kă pī ${ }^{26}$ pĩ mă ${ }^{27}$ lŭk nyì dă, sū dì ; ${ }^{28}$ dăng mŭlūt yāl dỉahirr ; dăng kăfwơn düm kăt lŭ kōl ; ${ }^{29}$ dăng düm kăt lŭ kōl, sìt dí; ${ }^{28}$ Dăng mŭlūt dümm $\operatorname{dōm}^{30} \mathbf{k}(\mathbf{w}) \bar{o}$ kě fwǒk ; ${ }^{31}$ dăng kăkŭr ${ }^{32} \mathrm{ji}$, kăt nyī, lì tè, ' ‘-fwǒk mē ?' těně, 'ăn-chīn ${ }^{33}$ kăfworn, dăng jī sìt dǐ'; ${ }^{28}$ dăng kăkŭr 'tă-yit ${ }^{34}$ dí kwăn-fwơk (n)ğhă'; kăkŭr dōm ${ }^{35}$ fworkkění; dăng dăp dăm, tăp; ${ }^{36}$ kăkŭr tě, 'Mǔlūt, ă-mět,

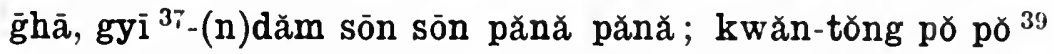
ğhā'; mŭlūt mět dì; dăng kăfworn lì tě, 'kăkŭr, à-mă ${ }^{39}$ gyī bwơp ${ }^{40}$ a-jī kěnǐ gnăn'; lĭ tè, 'mŭlūt kě jr kě dōm

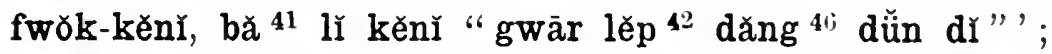
dăng mŭlüt lěp dăng nün lŭ kōl; dăng kăfwơn yăk ${ }^{43}$

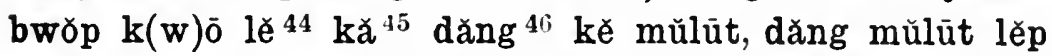
dăng, ${ }^{46}$ dăng kăkŭr, 'gwār pǔt ${ }^{47}$ kě dăng,' ${ }^{46}$ dăng pŭt kění; dăng kăkŭr tè, 'mē dō nē-nēt ${ }^{48}$ dē ?' ${ }^{49}$ dăng kăkŭr tě, 'ābē ${ }^{50}$ mũ rwăk'; ${ }^{51}$ dăng kăkūr' tě 'mǔlūt lẹp dăng kŭm ${ }^{52}$ kŭm, kō mū nē dĩ dăk, kŭ măn fwơkk kěnı̆ dí'; dăng lěb dăng dĩ; ${ }^{28}$ bě kăfwơn yē dăng kām ${ }^{53}$ kām; dăng kăkŭr lî tè, 'ă-pŭt'; dăng mŭlūt tě, ' $p \overline{1}$ cheūng ${ }^{5 t}$ gyì'; kăkŭr tě, ' kăfwơnn, à-yē kām kām'; dăng kăkŭr dăp dăm, tū dŕ; ${ }^{55}$ kăfwơn pŭt; dăng kăfwơn lì kě (n)kăkŭr těně, 'pī kă ${ }^{56}$ ār dŭng, mŭ yāl mět pănà'; dăng mă mět dí; kăfwơn düm lŭk ${ }^{57}$ kě kăkŭr dì, kō bě jì dí, kō mwăt ${ }^{10}$ wǔs, lŭk ${ }^{58}$ kă lŭ ${ }^{59}$ tābā; lŭk wŭs kă lŭ tābā; kō jī kǚk ${ }^{60}$ pơ kě mŭlùt dí, kō mět dí ${ }^{61}$ kăkŭr; lì tě, 'kăkŭr, ğhā

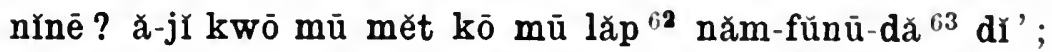
dăng mă ji dě; mă ji mă kăt mŭlūt kě tūl ${ }^{64}$ tābā (n)pó ; dăng kăfwơn lǐ tě, 'kăkŭr, tě, gwơ-dă kě bāl'; ${ }^{65}$ tě, 'mŭ sū'; dăng mă sū dě, dăng mă düm kă lŭ ; lr tě, 'bĭt kě măng, mět mū lăp dōn "í băl bāl zīn gnèt à?' Bìt măng, dăng mă pŭt mă mět dí ; mă ji mă dăb $1 ;{ }^{i 7}$ mă dăp ${ }^{68}$ mă

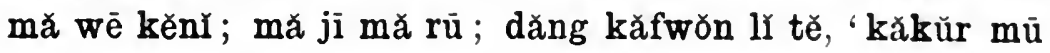


yǐt dị, kō fwăn kè tē dí; dăng kwō mū sě dî'; dăng kăkŭr mă wē; dăng kăfworn dăb ăm kō kē ${ }^{69}$ kěni pǒteūng, kō kwăt ${ }^{70}$ kă kē kĕ mŭlūt dĭ; kō kăfwơn mă dăp kĕ mătkèní kō mă chĕt dí, kō mă sě dí; mă ${ }^{i 1}$ mět ăm kĕ măt (n)kăkŭr ; ${ }^{105}$ dăng măt (n)kăfwơn ${ }^{105}$ dăp yĭss ${ }^{i 2}$ lěb lŭ tūl ${ }^{64}$ ăm kěnĭ; dăng măt $(\mathrm{n})$ kăkŭr ${ }^{105}$ lì tě ' yǐ kăt yǐss ${ }^{74}$ nē ?' 'i3 dăng măt nkăfwơn lì tě, 'dōn ${ }^{60}$ miss-nā mă i1 kĕ mìs-yī mă mă tū dĭ kā ?' 75 măt kăkŭr lă yĭss năm sār kĕ măt kăfwŏn lěp nün tūl kěnǐ pět; lì tě, 'gŭrm-mă tě mă lă tūl nĭ, bě tā, mě ${ }^{76}$ dăng mĭs-nā lăngăn'; mǐs-kěnĭ yāl lă tūl yēir āinhā, bě bě kěnĭ, lŭk kă shī kăkŭr, kō pĭn is kō yǐss yŏng '9 shī kăkŭr dĭ; dăng mǐs tě, 'kăt ${ }^{80}$ răng ?' tě, ' wū ${ }^{81}$ tū bì kě mwö̆l-ghā, bă-děn ${ }^{82}$-ăn kā pì mē ?' lì tě, 'yǐt, băng, ăn-măn'; kăkŭr chět $p(w) \overline{a 1}{ }^{83}$-pē kwō lěp chŭk ${ }^{84}$ kē nün gwìm; kăkŭr dăp gwìm pün măt kĕnĭ, tĕ, 'mèt kěnĭ kăfwŏn'; lì tě 'yī düm yī dăp kō̄ ${ }^{85}$ kă năr kē, yī pün nyì, tă-gwā ${ }^{s i}$ sě, kō gwār pün păk ${ }^{87}$ kĕnĭ jěb-mă, kō dăp sě, bě kě păk năng ${ }^{88}$ jěb mă'; dăng kăkŭr sìt nün gwìm, lì tě 'yī dăp, yī mĕt'; măt dăp mĕt kĕnĭ ; düm lì kě kăfwŏn tĕ, 'ă-dăp kō kă năr kē, kwă-dāl ${ }^{\$ 9}$ dĭ' kō dăp dāl $\breve{1}$; ${ }^{90}$ dăng kăkŭr băk ${ }^{91}$ nyī bŭt; dăng kăfwŏn lì tě, 'gnă ${ }^{22}$ măn ğhā kăkŭr'; lì tě 'kăkŭr ghā nē ğhüifănă bĭjĭm ${ }^{93}$ nyī kā ? ă-bwŏt ${ }^{94}$ gnăn kwăn pün ğhü-fănădă ${ }^{63}$ ghā' '; kăkŭr yīt băk-kĕnĭ dĭ, kō tŏng dōt; ${ }^{95}$ kăfwŏn tĕ ' ğhā, kăkŭr, ă-tŏng ${ }^{96}$ lă ${ }^{97}$ kĕ ghüu-fănă-dă ${ }^{63}$ kā'; kăkŭr băk shĭ chŭk; kăfwŏn tĕ, 'gyı̆ tŏk ā kŭk; kăkŭr ă-yĭt băk-fănă dĕ'; ${ }^{99}$ dăng kăkŭr pŭt kō kăfwŏn sĭt ${ }^{100}$ ghü̉ pün kăkŭr; dăng kăkŭr lă ğhü dĭ; dăng kăfwŏn chĕt gwīm kwăt; ${ }^{101}$ dăng kăfwŏn sīt, tŏng dün gwīm, lì kĕ măt tĭjī 102 kō yì dăp gwìm yi mĕt kĕnì kăkŭr; yī düm yĩ dăp kōos ${ }^{55}$ kă năr kē, yī pün nyī kăkŭr, kō nyĩ sĕ kō nyī bĕ kě păk pün jĕb mă'; kăkŭr dăp gwìm děn kă pī 103 wŭs ; kě běl ${ }^{104}$ wŭs; kăfwŏn pŭt kă năr kē kĕ lŭ tē (n)wŭs ; ${ }^{105}$ kō mūt dĭ. Kĕùt dăk. 


\section{NOTES}

$1=$ H. biri, a small monkey.

$2=$ H. gogo, baboon.

$3=$ H. Damissa, leopard.

4 pyār = 'jump'; ' his jump was such that he landed in a gaude tree.'

5 gwör $=$ H. gaule, ' a thorny tree.'

6 An exclamation $=H$. liai!

7 sIt $=$ H. fit da. See p. 115 , note 6.

8 The impersonal $=\mathrm{H}$. ' idan $a$-fit da kai . . .'

9 For bè à-.

10 The oratio obliqua. See notes $3,5,8$, and 12 , p. 113.

11 dōn = 'yestelday' lit., but is used for ' a little time ago.' See p. 53, para. 8.

12 The 'Continuous' Tense.

13 Lit. =H. ya fit da, ya buga; it means ' he tore his head off.'

14 An expressive exclamation; 'he got up, wap!' See note 15 .

15 An expressive exclamation; 'he hit the leopard, plup!' See note 14 .

$16 \mathrm{frl}=\mathrm{H}$. bare; 'he made string of bark.'

17 bāt ${ }^{\circ}$ 'to tie up,' ' bind.'

$18 \mathrm{~d} \mathrm{i}=\mathrm{H}$. wuri-n.

19 dă dō dă, the first dă may belong to nywē(-dă), or else it may help to emphasize dō da $(=\mathrm{H}$. ke nan $)$; dō dă sometimes becomes dă dō, especially if followed by ní.

20 mådăn, euphonic for mwăt gnăn.

21 yā, an exclamation ='Oh!' 'Oh! it was you, all right, who hit me, is this not so?'

22 The hare tries to make out it was some youngsters who threw the stone.

$23 \mathrm{kw} r \mathrm{~m}=$ ' ear.'

$24 \mathrm{kwă-măn} \mathrm{sé} \mathrm{=} \mathrm{'that} \mathrm{you} \mathrm{may} \mathrm{be} \mathrm{able} \mathrm{to} \mathrm{eat.'}$

25 lük = 'to throw'; kèsheǔk = 'all,' ' the whole,' 'with 
the body'; the leopard is deceived into thinking that if he seized the ears of the hare they would come off, so he takes the two ears and throws them on one side, and with them the whole hare, who thus escapes.

${ }^{2}{ }^{i}$ kà pì, or mole emphatically kà pi pì $=$ H. a-vwurin.

27 The impersonal = H. ' alia jefa shi.'

28 It will have been noticed by now that this di (see p. 108, note 8) is scarcely more than an enclitic of very frequent occurrence, and which can generally be translated H. 'wuri.' To be distinguished from ' $\mathrm{dI}$ ' the accusative, 'it.'

$20 \mathrm{kōl}$, almost $\mathrm{kö̈l}=$ ' a crab' $=\mathrm{H}$. liagua.

${ }^{30} \mathbf{d o ̄ m}=$ ' he bent down' (in order to dig).

31 dōm, 'to commence,' can generally be distinguished by its taking the (verbal) noun, note 35 .

32 kăkŭr = 'tortoise.' See p. 111, note 1 .

$32 \operatorname{chin}=$ 'to drive off.'

34 tă for tĕ ă.

35 dōm fwǒk-kěnĭ = ' commenced his digging.' See note 30 .

' 36 tăp $=$ 'br'eak.'

$37 \mathbf{g}(\mathbf{y}) \overline{\mathbf{i}}=$ ' to seek.'

3s pŏ pŏ ğhā or po ğhā $=\mathrm{H}$. zan jira bakinkla $=$ 'I will await your return.'

39 ă-mă gyī for ă mèt ă gyī.

40 bwop $=$ H. lioiya $=$ 'red earth.'

41 bà = bĕ ă.

42 lěp or lěb = 'send' lit., here = 'shove in.'

43 yăk = H. dila .

44 lè = H. zuba or shafe.

45 kă dăng = H. a-wutzia.

46 dăng = 'a tail.'

47 pŭt kĕ dăng $=$ H. fit da vutzia. Note the similarities of the two idioms.

4 nè-nēt = ' reddish.' See chap. v. para. 19.

49 dē ? = dì è ? 
50 ābē='perhaps.' See chap. x. para. 18.

${ }^{51}$ rwăk = ' to pierce.'

52 Reduplicated enclitic, here = ' carefully.'

53 = 'strong, strong,' i.e. ' (he held on) tight.'

54 cheüng $=$ H. gagar $\alpha$. See p. 89, ex. 28.

55 The accusative.

56 'The place is right on the road.' H. a-hainya.

${ }^{57}$ lŭk =lit. ' to throw'; here = 'he slipped away.'

58 See note 57.

${ }^{59}$ lŭ tābã = 'a pipe.' See note 64 .

${ }^{60} \mathbf{k u ̈ k}=$ 'propped' (it in). See note 18, p. 114.

${ }_{61} \mathrm{~d} \mathrm{I}=\mathrm{H}$. vurin, to the place of.

62 lăp $=$ H. duba.

63 See chap. ii. paras. 1, 3.

${ }^{64}$ tūl $=$ H. tulu ; here $=$ 'pipe.' See note 59.

${ }^{65}$ bāl = 'cure,' ' get cured.'

66 dōn. See p. 114, note 14.

67 dăb I for dăb dý.

68 dăp or dăb.

${ }^{69} \mathbf{k e}=$ ' to climb'; 'that he might climb up with it above,' the subj. with kō.

${ }^{70}$ kwăt = 'to pour out, drop by drop.'

71 Note the pl., 'she went to the water with the wife of the kakur.'

72 yiss $=$ ' bone.'

i3 nè ? for ninē ? = 'where?'

74 'A bone.'

${ }^{75}$ kã for kā à? 'Did not your' husband and mine kill it a little time ago?'

${ }^{76}$ me dăng = 'unless'; the dăng is more frequently placed

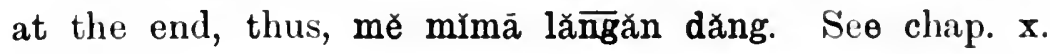
para. 22.

${ }^{77}$ yē annhā may be, 'he took it thus,' or yẽ may be an exclamation; the ànhā, 'thus,' is accompanied by an explanatory gesture by the storyteller.

${ }^{78}$ pin or pin = ' to break in little pieces.' 
79 yong = 'to pierce.'

so kàt răng? or' pŭt răng?=H. mi ya faru? = 'what's the matter?'

81 Note the pl. including the husband and his relative, 'mwŏl-ḡhā.'

S2 bă-děn-ăn = bè ă-děn gnăn.

83 pwā-pē, another word for gwìm $=$ H. gaya.

$s 4$ chŭk kē = 'a razor.'

85 kă năr kē= 'above'; the kõ transforms this adverb into a noun = 'that which is on top,' or ' the upper thing.' See p. 113, note 10, and chap. v. para. 8, and chap. iii. para. 8.

Sí tă gwă=tè ă gwā='say, that you (should) eat.' See note 9, p. 143 .

87 pak = 'the remainder.'

ss năng, a Hill Angass word for' pün = ' give.'

s9 dāl = 'swallow.'

90 dāl r for dāl dí. See note 67.

91 băk= 'to cut.' See note 27 (a), p. 102.

92 gnă for gnăn.

9 ' bǔjî́m = 'very big,' ' fine and big.'

94 bwot = 'r'elease.'

$95 \mathrm{dōt}=\mathrm{H}$. liaurvi = ' he remained quiet.'

96 tonng = 'remain,' 'sit'; also, as here, 'to be enough,' ' to be wor'thy,' ' you are not wor'th taking my sheep.'

97 The ker after lă shows the latter to be a verbal noun $=$ H. la lia iss a liarbe-n-akwia-ta.

is a kŭk = 'thus stupidly.' 'The hare said that he was speaking stupidly,' or, perhaps, ' in fun.'

99 dě frequently for dĭ.

100 sǐt $=$ H. fit da.

101 kwăt = 'also,' ' too.'

102 tǐjī for tě yī jī. See p. 109, note 23.

103 kă pi wŭs $=$ H. a wurin vuta; pr wŭs is frequently used as here, for the apex of the hut where the smoke goes up and escapes, ' he put it, or hung it, above the fire.' 
104 běl = H. fura, ' he lights a fire.'

105 (n) euphonic.

106 p. 117 , mwăt wŭs = H. ya buga wuta, he struck file, indicating the use of the flint.

\section{FREE TRANSLATIONS}

The following are very free translations of the last five stories. With the gist of each sentence given him, as well as the notes, the learner should have little difficulty in arriving at the literal translation. With no other literature available at present, something must be left to individual effort.

\section{The Kurgutan and the Crown Bird, p. 111.}

The kurkutan and the crown bird debated together their prowess of flight, after some discussion the crown bird said, "Well, let's make a flight, and the one that tires first shall give a present to the other.' So they started and flew, and the crown bird tired. On their return to the starting-point, the crown bird came up and paid over the stipulated present.

\section{The Tortoise and the Hare, p. 111.}

The tortoise and the hare were in their farms marking out their boundaries; they ate their lunch and got up to wash. They agreed to play 'lechcha,' and the hare said, 'I'll have a hit at you first, tortoise,' and took his dive to hit him. He succeeded, and drew blood. The tortoise got out and ran off saying, 'For the future, I'll not play with you again'; he went away and, not returning, the hare came out, and they separated. 


\section{The Hare goes Hunting, p. 112.}

The hare went off to hunt; he came across some fish who were dancing and playing. He said to them, 'You dance splendidly; come out to me on the bank.' They did so, and he said that, as the sun was hot, he would build a grass hut for them. So they danced inside the hut. But the hare set fire to it, and they were all consumed. Just then a leopard came up and saw him. He told the hare to pick out the biggest of the fish and give them to him. The hare replied, "No, leave the big ones for me, and I'll show you a prettier pattern for a skin than yours. You know the guinea fowl; well it was I who worked out hers for her, and some time ago I said I'd do your's for. you too.' So the leopard said, 'Very well, let's share the fish,' which they did. After that the leopard said, 'Good, I'll go with you now, hare, that you may mark me,' and the hare replied, 'All right.' So they went off and came to a tree, and the hare called out, 'Come, leopard, I'm ready to mark you,' so the leopard came up; and the hare went on, 'Come close to the foot of the tree,' so the leopard came and stretched himself up along the trunk of the tree. The hare then took some rope to tie the leopard up. The latter growled, but the hare said, 'You must not make the slightest move, or else the pattern will spoil,' so the leopard kept quite still. The hare then took up a stick and hit the leopard on the head, and the leopard died. The hare then called out to his wives, and said that he had killed something well worth having. So his wives came along, and took away the leopard to their home, and, arriving there, ate him.

The Guinea Fowl and the Hare, p. 114.

The guinea fowl had cleared a space in the bush for her farm The hare left his farm, and, going off into the 
jungle, came across her corn, which he saw was excellent. Seeing no road, he took up a hoe and cleared and made one. The guinea fowl started off for her farm, and came along flying. Early next morning the hare went off too, and arrived there. While there the guinea fowl flew down, and found the hare bending down at work. She called out, 'Who is that working on my farm?' The hare inquired, 'Oh! is the farm yours?' 'Yes,' replied the guinea fowl, 'it is mine.' 'Where, then, is your road?' asked the hare. 'I fly,' said the guinea fowl ; 'my road is in the sky.' 'You lie,' answered the hare, 'the farm is mine; look at my road stretching right along here,' and he so threatened the guinea fowl, that she got frightened and went away; leaving it to him. So the hare worked on at that one, and abandoned his old farm. That's how it is that, being frightened, she left her furm to the hare, and now comes and eats the corn on men's farms:

\section{The Monkey, the Leopard, the Hare, and The Tortolse, p. 116.}

The monkey went out for a walk; on his way he came across a leopard fighting with baboons. In his dashes at them he took such a leap that it landed him in a thorny tree, and, as the monkey came up, he saw him in the grip of the tree. The leopard called out, 'Hi! monkey, help me out.' 'If I get you out,' asked the monkey, 'will you leave me alone when you are free?' The leopard promised, and the monkey freed him. Just then the hare turned up, and, seeing them, asked, ' What were you quarrelling about?' 'A little while ago,' said the monkey, 'the tree had hold of the leopard.' 'The hare, thinking he ought to say something, was in the act of addressing them, when the leopard seized the monkey and tore his head off. The hare started up hurriedly, and, picking up a stone, hit 
the leopand on the head with a whack. Seeing he had lit the leopard, he dashed off to go and hide. The leopard pursuerl, and the hare, seeing him coming after him, quickly stripped off some bark and bound it round his foot, and then returned to the leopard and inquired, "What are you looking for?' 'The leopard replied, 'Don't I know it was you?' 'What,' asked the hare, 'has been done to you?' 'Wasn't it you who hit me?' said the leopard. 'Look,' replied the hare, 'my foot is damaged, and has' been so for a long time.' 'You are the strongest of us,' he went on, "What are you going to "lo to the boys who played this trick on you?' "I know perfectly well it was you,' replied the leopard, and promptly seized the hare, who cried out, 'You are stronger than I, of course, but if you catch hold of my ears, and throw them there, over: yonder, you will be able to eat me properly.' So he took hold of the hare, ear's and all, and saying, 'Very well,' lifted the hare, ears and all, and threw him to one side. The hare started up from the place he was thrown to, and made off hurriedly. The leopard too at once got up and went after him. The hare on his way found a crab's hole, into which he dived. The leopard coming up settled himself down to dig him out. In the meantime the tortoise arrived, and, seeing him, asked what he was digging for. 'The hare,' replied the leopard, 'has bolted from me and gone to ground here.' The tortoise offered to dig for him, and set to work, but the stick he was digging with broke, so he said, 'Go away over there and fetch me a long one,' and the leopard went. The hare then called out, ' $\mathrm{Hi}$ ! tortoise, go and get me some red earth, and when the. leopard returns to his digging, tell him to put his tail down here'; so the leopard put his tail into the crab's hole, and the hare smeared it all over with red earth.' The tortoise said, 'Now take your tail out,' which he did, and the tortoise exclaimed, 'What's all this red?' and after a bit he went on, 'Perhaps you have pierced the 
hare, and this is his blood.' After a little thought he said, 'Leopard, put your tail in again carefully, that we may see exactly where to dig.' So in went the tail again, but the hare held tight on to it. 'Now, then,' said the tortoise, 'take it out again'; but the leopard replied, 'I can't, something's caught'; whereupon the tortoise cried out, 'Hold on to it, hare,' and, taking up a stick, killed the leopard. The hare then emerged from the hole, and said to the tortoise, "We are right on the road, let's get further' off.' As they went the hare gave the tortoise the slip, and, returning, struck a light and lit a pipe, and, having fixed it in the leopard's month, turned towards the tortoise and cried, 'Where are you? let's go back and have a look at our spoil.' They went and saw the leopard with a pipe in his mouth. 'Hullo! tortoise,' cried the hare, 'the fellow's getting well, let's be off.' They fled home, when the hare said, 'In the morning we had better go and see if he is really dead or not.' So next morning they went off, and, lifting him up, took him back home. 'Tortoise,' said the hare, 'let's leave him for the rain to fall on him, he will be better eating like that.' So the tortoise went off, and the hare, getting some water, climbed up over the leopard and poured it over him in drops, meaning to take it to his wife to cook and eat. Now his wife met the tortoise's wife at the water-hole, and she had put the joints in her water pot. Mrs. Tortoise asked her where she had got them from. 'Why!' replied Mrs. Hare, 'didn't your husband and mine kill it a little while ago?' Mrs. Tortoise then took the joints and put them into her own pot, saying, 'If anyone asks for them, I shall refuse to give them up, unless it's my husband.' The latter rose up to take them from her, but she stepped back, and threw the pot at his feet, so that it was smashed to pieces, and a bone ran into his foot. 'What's the matter?' he asked. 'How is it,' she replied, 'that you and a friend of yours go and get some game, and you bring me none?' 
' Wait a bit,' he said, 'I know all about it.' He then cooked some soup mixed with flour, and put a razor in it, and gave it to his wife, saying, 'Take this to the hare, and give him the upper portion, and tell him to eat it, and give the rest to his youngsters; and be sure he eats it and gives the rest to his children.' He then got into the soup himself, and said, 'Now pick it up and go.' She lifted it up, and taking it to the hare, gave him the upper part, and said, 'Swallow it.' He did so, and the tortoise began to cut away at his inside with the razor. He cried out, ' $\mathrm{Hi}$ ! tortoise, I know it's you,' and after thinking a bit, he said, 'You know my sheep; it's a fine big one, isn't it? Well, if you'll stop this business, I'll give him to you.' So the tortoise left off and kept still, and the hare said, 'Come, now, tortoise, you are not fit to have this fine sheep of mine,' whereupon the tortoise set to work cutting again, and the hare called out, "What I said was only in fun, I didn't mean it.' So the tortoise stopped and came out, to let the hare go and get the sheep, which he took away with him. Then the hare in his turn cooked some soup, and got into it and sat down, and, calling his wife, said, 'Come, take up this soup and go to the tortoise and give him the upper portion, and let him give the rest to his children.' But the tortoise took the soup and hung it up from the centre of the roof, and underneath it he lit a fire. The hare leapt out from above, and, falling into the fire, died. The end.

Note.-The wives of a man all bring their dish of food to the husband, who takes a little off the top of each, and gives the rest to the others of the household, every evening. If a man should abstain from touching any particular woman's, which, if he did, he would do deliberately, she considers it so great an insult, or so great a lack of confidence, that she would at once leave him and go off back to her mother's house. 


\section{CHAP'TER XVIII}

1. As the main object in writing this Grammar is to show a connection with Hausa, and to dhaw attention to the possibility of its being the root language of the group to which it and Hamsa belong, it will be as well here to summarise the chief similarities between the two.

2. To commence, we will note some of the words which are obviously of common origin. It must be remembered that Angass is a distinctly monosyllabic language, whereas Hansa dislikes a word ending in a consonant, and makes a dissyllable, at least, of it where possible.

Angass.

\begin{tabular}{|c|c|}
\hline măt & màtü \\
\hline mis & $m \check{\imath} j \check{r}$ \\
\hline năm & nèmè \\
\hline mūt & mǔtŭ \\
\hline rěb, rı̌b & răblü \\
\hline pŭk & bülič \\
\hline pŭt & $\dot{f} \breve{\imath} t t \breve{a}$ \\
\hline kör, quarrel, fight & livire \\
\hline tŭl & trŭli \\
\hline wē? wã? & wī? \\
\hline $\mathrm{mē} ?$ & $m \bar{\imath} ?$ \\
\hline kō-wē & lio-wa \\
\hline$k \bar{e}, \mathbf{k a ̄}$ & liai \\
\hline văng & ǚ̆nličr \\
\hline dǔk (Hill Angass) & dulia \\
\hline tŭm (Hill Angrass) & tümliěr \\
\hline song & sănyă \\
\hline Jid, yit & $\check{\imath} d \bar{i}$ \\
\hline
\end{tabular}

English.

woman, wife.

husband, male.

meat, flesh.

dead.

divide.

grass hut.

go out.

drive away.

wen, tumour.

who.

what.

anyone.

a hearl.

wash.

all.

sheep.

chatuge.

eye. 
Angass.

Hausa.

săk

sütici

săk

săsăliā

(săk = cut

$\breve{a} \operatorname{sk} \bar{\imath}=1 \mathrm{azor})$

$\bar{e} \bar{e}, \bar{a} a ̀$

$\bar{u} \bar{\imath}$

English.

bì

shwē, shwā

ätru(-n)

shai

sě

clì

dăp

dăpliā, dauliā

děng (Sura)

dĕnḡi

tŭm, descend, jump down

\} tümà

nǏn ē ?

ènnū?

găm = to be full gămmī

gwir, odd one,)gwămrō, gōro, umpaired gŏbrō, gōrŭ̄à gŭzŭm, field rat, mouse

shēuk

kăt

küt

kām, to be strong, to seize

kār

gyĭn gyinn

kwăs

kèt, a boundary liètāiè

$\mathrm{k} \bar{i}$

kō-

kwork

kül, a knot, to tie)

a knot

kūr

mir

mǔs

nŭn, nŭng bǐus

kㅇ-

liōkitāa

fiǔllĭ, kiüti

liǔnliùu

mürjē

mŭssā

nünā weave.

cut, carve.

no.

thing.

drink.

eat.

lift, carry.

family.

jump.

where?

finish, complete.

\}archelor, spinster.

field mouse.

body.

lest, that not.

crocodile.

seize.

tamper with.

small.

the itch.

cross over.

defend, protect.

as in ko-wa, etc.

wrestle, fight.

knot.

tortoise.

twist.

cat.

to be ripe. 
Angass.

Hausa.

English.

rŭs, to bend

rŭs̆̌nї, rünš̆nй

to do obeisance.

sŭm

sūnè

name.

sür, father-, son-)

in-law

sürli ̌

father-in-law.

tūl

tū $\bar{u}$

tūs

tüsȟ

water pot.

wŭl, turn aside, ? miss the road $\}$ wulga jür

$z \bar{u}{ }^{\circ}$ root, of a tree, ete. pass by, pass away. spite, malice.

And see also para. 37 below.

3. It will be noticed that practically all these are elementary or essential words, which every language must have from its beginning for itself. They are not the type of words which one language would borrow from another. Again, where Angass does borrow from Hausa, the borrowed words are of more than one syllable, e.g. Angass tŭkŭn, from Hausa tuliunia; and vrìlī, from Hansa mărìlì.

4. In Hausa most of the words end in ' $a$ '; some in ' $e$ ' and ' $i$,' and a few in ' $u$ '; of the last, the ' $u$ ' of the Hausa mutu is due to the fact that the ' $u$,' in the Angass mūt, is long. Again, take the two words tūl and tŭl in the above list. 'The first, in Hausa, becomes tūlū, but the second, tŭlĭ. From kūr, too, the Hausa is kŭuliŭru.

The ' $\mathrm{e}$ ' sound, again, in kör, induces the Hausa to be koore, and not kivrē, and so on.

5. In Hausa we find that the root of the verb undergoes no inflexion for tenses or person. We have the same in Angass :

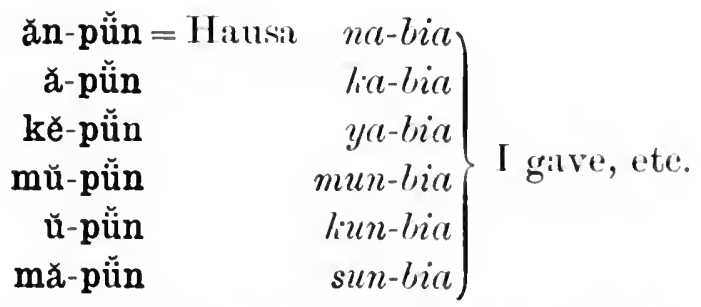

where the roots pün and bia undergo no change. 
6. In Angass, and to a large extent in Hausa, the above one form does duty for all our different tenses-the past, present, or future being inferred from the context. 'Thus a foreigner learning English might say, 'I go today,' 'I go to-morrow,' 'I go yesterday,' and ' he go tomorrow' and would be quite understool. (See chap. vi.)

7. 'The curious 'Continuous 'Tense' of the Hausa has its exact comterpart in the same construction in Angass, i.e. the H. ' $i$-na so-n rua' = the Angass' 'gnăn kĕ rōt kĕ ăm,' the lattel', however', having become more idiomatically 'gnăn po rōt kě ăm.' (See chap. vii.)

8. Our passive is expressed in Hausa, as in Angass, by the use of the impersonal signifying 'one,' or 'they,' or 'people.' Thus in Hausa ' $a$-n bami liurli' = 'one has [or' people have] given me money,' i.e. 'I have been given money'; which in Angass is 'mă pün jělmăt gnăn.' (See chap. viii. para. 13 and seqq.)

9. ' kă' in Angass is put to the same constructive uses as ' $a$ ' in $\mathrm{H}$.

e.g. Angass kă-pŭtōm = H. a-gablba.

,$\quad$ kă-pi-dă $=$ H. $a-\imath u v i-n$.

and again in the participial or alverbial forms, as

, kă-sū-sū = H. a-gruje=a-rumning.

, $\quad$ kă-dōm-dōm = H. a-tsugune = a-bent.

See chap. viii. paras. 16 and 17 .

10. The definite future, 'I am going to . . .', is in both, as with us, compounded with the auxiliary verb, 'to go,' which is 'mĕt' in Angass, and ' $z a$ ' in Hausa.

11. In both, our infinitive is expressed by the use either of the verbal nom or the subjunctive; and, in both, parallel phrases with a preposition or the future forms are employerl. 
12. In Angass prepositions are rarely used. In Hausa two or more prepositions are used together, but the best Hausa is to use none, or as few as possible.

13. The same prefix, ' kōo', is used both in Angasss and Hausa to form the indefinite pronouns ' $k \bar{o}$-wēe,' 'lio liaka,' etc. This is the more noteworthy, as the inljuncts of words in both languages are suffixes and not prefixes, e.\%. Angass, '-chĕ,' '-nŭ,' '-pănă,' etc., and in Hausa, ' "'a-ne,' 'wa-n-nan,' 'wa-n-da,' etc.

14. The Hatusa has a verb 'yi,' ' to do, make,' which is put to a variety of uses straightforward and idiomatic. The Angass has a verb 'chinn' which has identically the same meaning as ' $y i$,' and which is put to identically the same idiomatic and straightforward uses; e.f. II. ' $y a$ yi

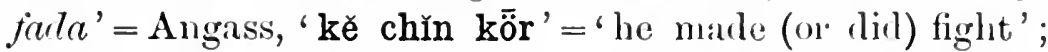
i.e. 'he fought,' H. 'wa-n-nan ya yi wa-n-chan'= Angalss, ' kōonì chĭn kōo-pănă' = ' this one makes that one,' i.e. 'this is the same as that,' H. 'ya yi sheliara hudu' = Angass, 'kè chin yī fïr' = 'he makes four year's,' i.e. 'he is four' year's old,' etc.

15. In Hausa plurals, if in the sentence there is a word which itself connotes the plural, the singular forms of the nouns are used in preference to the plural. These last are so complicated that the use of the singular', whenever' possible, might be considered as due to that fact. In Angass, however, the plural formation is exceedingly simple, merely the addition, without exception, of '-mă,'

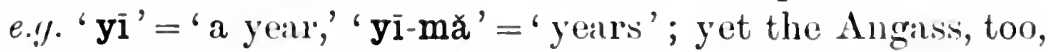
uses the singular' forms in similal' occisions; thus, the Hansa for 'two men' is 'mutum bin,' where 'mutum' is the sing., and not 'mutane biu' (mutane is the pl. of mutum), because 'lin' (which $=$ two) itself connotes the plural. The same occurs in Angiss, e.\%. 'two men' is 'gŭrm bāp,' and not 'gŭrm-mă bãp.'

16. The peculiar method of comparisons of adjectives 
and alverbs is precisely the same in both, the Angass 'dèl,' 'to surpass,' taking the place of the Hausa ' $f$,' which has the same meaning.

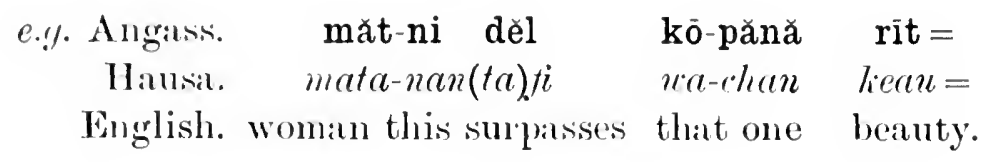

Agrin

Angariss. brüng pð sū děl gŭrm wŭrn= Hausi. roli (shi-) na !/urlu (ya), fi mutum sauri= English. horse runs it surpasses man swiftness.

In Angass, however', the preposition 'shr̆,' 'with,' is permissible.

i.e. Angasss. brüng pǒ sū děl gŭrm shl̆ wŭrn= Hausa. doli $($ shi) na yudu (ya)fi mutum da sauri= English. hor'se runs it sumasses man with swiftness. See chap. xi. para. 1-5.

17. The verb 'to have,' in both, is rendered by the prep. 'with' ='kě' in Angass and 'cla' in Hausa; e.g. 'I have a hor'se' = Angass 'gnăn kè brüng' = H. ' $i$-na $d a$ doli,' i.e. 'I (am) with (a) horse.' Chap. i. para. 23.

18. The demonstrative pronouns in both are suffices, e.f/.

II. doli $i-n$ nan = Angass brüng-nц̌.

H. doli-n chan = ", brüing-pănă. Chap. ii. 1 .

19. The negative imperative in both employs the same word, i.e. 'kaddl' in Hausa and 'kăt' in Angass.

20. Both have a word to translate, 'there is - there are,' viz. ' $t$-liuoi' H., and 'dí' Angass. Chap. ii. 14.

21. Both employ the letter ' $n$ ' for euphony.

22. Both have separable and inseparable forms of the 
possessive pronouns; and in both, again, the lattel is suffixed.

23. The idiomatic use of the plural pronouns in many' cases where we should use the singular is common to both, though to a less extent in Jausa, e.!

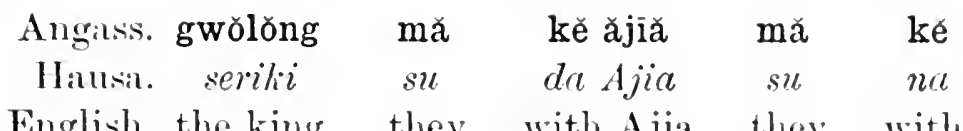

English. the king they with Ajia they with

$\begin{array}{cccc}\text { lěŏk } & \text { kè } & \text { shăk } & \text { vèng } \\ \text { faula } & \text { llı } & \text { junc } & \text { lullum } \\ \text { fighthing with eitch other ilways. }\end{array}$

And take, too, the Hausa sentence, 'ana-maganata dis yaro nan, anihe hamar-mu laia da shi, amma lia alrinde ya yamma mu da shi,' where the literil translation of the portion in italics is, 'people say our likeness is one with him, but there is nothing which joins us with him, i.e. 'people say I am like him, but there is no relationship between him and me.' (See the notes to the 'Tilles, e.g. p. 121, note 1, and P. 131, note 1.)

24. Both have a prefix for a noun agent, which is used in precisely corresponding ways. Chatp. v. 1.

25. Adjectives in both languages are formed from nouns by the aid of the prep. "with'; e.y. H. 'da dadi' = Angass' 'shı̆ shăng' = 'with sweetness,' i.e. 'sweet.' This occurs oftener in llausa, because Angasis has more true arljectives.

26. 'The Ilausa 'beri' and the Angrass' yit,' both meaning 'to leave,' to let,' are used in the simme wily to produce a form of the imperative. Chap. viii. para. 8.

27. In both, an adjective, lenoting colour, reduplieated, denotes a lighter rather than an intensified shate of that colour. Chap. v. 9.

28. In both, special enclities (or perhaps adverbs) are 
userl with certain colours, and only with them, e.g. H. 'ja wur,' 'haliki kivin,' where ' wur' is only used with ' $j a$ ' and 'livin' with 'balilii' ; Angass' 'nět gāu,' where 'gāu' only accompanies 'nět,' 'red,' and no other' colour.

29. The phrasing of the Angass follows, practically exactly, that of Hausa, i.e. Angass can be translated into literal Hausa, and make good intelligible Hausa. See example in para. 23 above, and in the interlinear tianslation of the Tales.

30. The Hausa has a very clumsy way of tracing relationship, but, such as it is, the Angass has an identically corresponding one; e.g. H. 'mun yammu voje-n $u b a '=$ Angass 'mŭ kăng kwăng kě pŭp' = 'we are joined in the direction of the father', i.e. 'we ar'e related on the father's side.' (H. 'gammu' = Angass 'kăng'= 'to join'; H. ' iroje' = Angass ' $\mathrm{kwăng}$ ' = 'side, direction' ; H. 'uba'= Augass 'pŭp' = 'father.')

31. The reflexive pronouns are formed in both by exactly the same idiomatic turn 'with the head of'; that is, 'da kai' in Hausa, 'sh $\mathrm{ke}$ ' in Angass; e.g. H. 'mu da kai-n-mu' = Angass ' mŭn shĭ kē-fŭnū' = 'we with our' head,' i.e. 'we our'selves.'

32. Both have a narrative past formed with the same particle ' $l i a$ ' e.f. H. 'su-lia taffi ' = Angass 'mă kă mĕt' (but see note, chap. viii. para. 5).

33. Turns of certain idiomatic phrases are identical in structure and genius of thought, e.\%. H. 'ja haimya'= Augass 'dắng ăr' = 'to pull the road,' i.e. 'to guide'; $H$. ' ba rua-nka $b a$ ' = Angass' 'ăm-ḡhā dî́kā' = 'it is not your water,' i.e. 'it is no business of your's'; H. 'ku taffi abinku' = Angass ' ŭ-mět bī-fū' = ' go, your thing,' i.e. ' be off with you'; H. 'yenke karia' = Angass ' chăn kwŏlm' = 'to cut a lie,' i.e. ' to tell a lie'; H. 'suna-ntia lialia?'= Angass 'sŭm-fā răng ē ?' = 'how is your name ?' i.e. ' what is your' 
name'; H. 'shi lie nan'= Angass ' nyi dō dā' = 'it with the thing,' i.e. 'it is it'= 'all right'; and so on.

34. The H. ' rua ni ke so' = 'I want water', and the 'ke' is at present taken to be the verb 'to be.' If it were so, the translation would be 'water I am wanting,' where 'so' or ' wanting' is a participle: 'so,' however, is not recognised as a participle. 'The 'lie' is in origin the Angass prep. ' $k e x '=$ ' of ' and 'with,' and the correct translation is 'water I with wanting' (i.e. 'I want water'), where 'so' is the verbal noun, which is seen more clearly to be the case if the sentence is slightly transposed thus, " "i lie so-n rua,' where '-n' is the genitive, 'I with want of water.' Again, H. 'Karia shi lie $y i{ }^{\prime}=$ 'a lie he with telling' $=$ 'he is telling a lie.'

35. In Angass, 'any man ' = 'kō-wē kě gŭrm.' and 'any woman' = ' kō-wē kě măt.'

where the use of the prep. 'kè' is noticeable, and the lit. translation is 'any one of man,' 'any one of woman'; and from this it appears probable that the corresponding Hausa expression, 'ko-wa-ni mutum,' was originally 'lio-ka na mutum,' which accounts for the fem. form 'ko-wa ta mata.'

36. In Angass, 'a thing' is ' bì.' In Hausa it is 'alu,' but in compounds 'alu' reverts to its original derivation, e.g. 'a-bi-nda,' ' a-bi-nmu,' etc.

37. IIausar words can frequently be traced to Angass. 'Take as eximples the Hausa words, 'chacha,' ' the gambling gatme,' 'tuntuni,' 'long ago,' and 'Tivungura,' 'a large shiell.'

It will have been noticed that in Angass' words are very frequently reduplicated, e.g. 'kŭm kŭm,' 'kět kět,' 'yāl yãl,' 'mār mār,' etc. If a consonint elosing a word is difficult to pronounce in its reduplicated form, it is omitted in the first syllable; thus 'yāl yãl' becomes 'yā yāl,' and 
'mār mār' becomes 'mā mār.' Now, among the Angass there is a game in which two men shoot arrows at an "pright stick or tree. Whoever hits the stick takes an n'row (păs) from the other competitor if the latter misses. 'This is the only form of gamble of any sort that is known to them, and is called 'chăk păs'; any one playing it is saidl 'chăk chăk,' or chă chăk, whence is obtained the II. 'cha rha.'

Again, 'tī' means 'long ago,' and 'tī tī' = 'ages and ages ago'; the latter is softened in conversation by an euphonic ' $n$,' and becomes 'tì-n tì,' whence the Hausa 'tuntuni.'

'kün-girn' is the Angass word for' a shield. Being a dissyllable, it is presumably a compound, and, in fact, ' kü̈n' is a 'buffalo,' of whose hide the toughest and largest shields are made, and 'gurp' or ' kirrp' is ' to cover', 'protect,' 'ward off.' From 'kü̈ngirp' is derived the $\boldsymbol{H}$. 'kurungura,' which (see Robinson's Dictionary) is 'a large oblong shield like that of a Zulu.'

38. To summarise. In the above paragraphs we have about thirty points of resemblance, some of them identical, between the two languages. Many of them are of great importance, and the remainder, perhaps, are not of so much consequence; nevertheless their cumulative effect can leave little doubt of the connection between the two; but whether this connection is direct or lateral only a further study of the local languages can make clear. My own opinion is that Hausa is an immigrant hybrid language, grafted on an Angass stock; the basic structure of the two is identical (see, however, next sentence for some exceptions), but Hausa has called in the aid of several vocabularies for words to express ideas which the primitive Angass has never had occasion to interpret. There are three great points of dissimilarity, viz. that Hausa has gender, an irregular plural, and an intransitive or passive for'm in '-u,' all of which are lacking, even in the 
principle, in the Angass. The first and third of these can, I think, be readily ascribed to Arabic influence; the second is a greater difficulty, and may perhaps be a retention from the original language of the Hansas before their assimilation into the tribes of $\mathrm{N}$. Nigeria; and if my points are accepted, then, Angass being a Negro language, Hausa must be transferred from its present location anong the Hamitic languages.

One characteristic of the people must be borne in mind, or else wrong impressions may be gathered during conversation, and this is what may be called, on the one hand, a sort of false pride, and, on the other, self-respect carried to excess. It shows itself in many ways, the chief probably being an unwillingness to appear to be under an obligation, however small, to anyone else. Thus a man may pass another at his meal; the latter will call to the for'mer to come and join him at it. The answer is at once a 'No.' The invitation is repeated, to be declined again; the invitation goes forth a third time, but couched differently, 'Well, then, come and tell me your news.' 'This is readily accepted, and, on sitting down, he shares the meal as a matter of course; he would have been disappointed if his first or second 'No' had been taken seriously.

On the death of a king, again, the king elect is told in open council that he has been selected to succeed. He at once says he does not want the honour. The spear-the badge of office-is handed to him to take hold of. He refuses, and continues to do so, edging away from it, till he is seized, and his hand is forcibly clasped romed the shaft. To have seemed eager to alecept would have given a bad impression, and is 'bad for'm.'

In small matter's, too, the same trait is discernible. For instance, a man has done a hard day's work, and is obviously tired; he will evoke sympathy - How tired you must be!' but his acknowledgment will be, 'Oh! no, not a bit.' $\mathrm{Or}$ if a man is congratulated on extra good 
harvests, or a sudden accession of wealth, his answer will take the form of the sentence on p. 97, line 15, 'My poverty is only slight,' ' I can just manage,' etc.

The same sort of thing is noticeable among a certain class at home; for instance, a 'Tommy' may be offered the anticipated drink after some work; or a meal on a jouney; or a theatre ticket, etc.; his answer is never a straightforward 'Yes, please,' or 'Thank you,' but is always of the form, 'I don't mind if I do.'

'This 'pretended reluctance,' or 'hiding of an unseemly

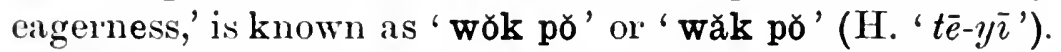
It is a species of excessive caution not to put oneself in a position of ridicule. For instance, if the man, asked to join in the meal, accept at once, he might, on arrival, find the dish empty, and the laugh would be against him. If, however, he is merely asked to come and sit and talk, then he has time to look about him.

The Negro race has almost certainly been less reacted on by the influences of outside races than any other in the world, and consequently its customs and languages are more conservative, and have had a longer continuous existence than any others. The Chinese are the only people who can compare with the Negroes in this respect, but their history traces the lessons of foreign invasions and alien dynasties-episodes undiscoverable among the latter either from internal or external records. Egypt, it is true, influenced Ethiopia to a large extent, but the people of the latter country were cognate to the Egyptians, though more nearly allied to the Negro than to the latter, and it is difficult to discer'n any Egyptian impress on Negro thought.

In so self-contained a people, the Angass language is a very primitive one even in a country of primitive peoples; and it is interesting from that point alone, apart from its relationship to Hausa. Its construction is as simple as possible and this might be thought to limit the expression 
of ideas, but where a paucity of grammatical forms fails, idiom comes to the rescue. 'T'hus ' $\breve{u}$-chĭn kō-nĭ, bě mŭ jị ka' might mean, 'if you do this, we shall not come,' or' 'do this, before we come.' The context, as a rule, is sufficient to indicate which is meant, but even that might fail, so the sentence is left alone to indicate the former, and the latter' becomes idiomatically ' $\breve{u}$-chrn kō-ní, ŭ-kŭt $\breve{u}$-chin kă shī-nū', which, though difficult to turn into English, gives a fairly clear impression in the literal Hausa, 'Iin yi wannan, lin tukuna ku yi a-zuct-rmu', = 'you do this, you not yet, you do at our coming.' 'Though the idlioms are strange to our mode of thought, and consequently almost impossible to turn into English, nevertheless they are all perfectly in order from an Angass grammatical point of view. In these idioms it is not the grammar, but the juxtaposition of ideas, that is baflling. Though the grammar is so different in form from our's, yet it is quite intelligible-because so simple. Where the modes of life and of thought are so dissimilar from our own, it must be expected that the mode of expression, i.e. the grammar, must be very dissimilar too. To show how puzzling a language can become, I quote the following example from Armbruster's Initia Amharica (Athiopian), and we may well be thankful that Angass, and consequently Hausa, is as simple as it is:- "Where the parent language, South Arabian, would have said, " $\mathrm{My}$ brother, who started yesterday for Gondar, led by evil thoughts, entered the house, and stole the money from my father's box, and went off," the Abyssinian of to-day would put it, "Yesterday to Gondar to go I am saying, who started my brother evilly thinking in my father's box which there is in it money into the house entering stealing (literally his -he-stole) went"' (p. 193). "Here we see the narrator, insteal of giving a series of distinct actions in ordered succession, makes an effort to present the totality of the facts in a single sentence, gerunds, and a unique tense, 
the preterite with a possessive suffix being employed as qualifying and amplifying the action, but without definition of time as rendered by verb tense.'

If any one were deliberately to set himself to give the sense of the first sentence in as complicated a form as he could, it is doubtful if his effort would equal the actuality of the Abyssinian.

Where, therefore, a sentence is explained by a grammatical form very different to ours, the explanation must not be looked at askance, necessarily, nor, on the other hand, need we expect to find forms similar to ours, for, the great probability is, they do not exist. 


\section{VOCABULARY}

$\bar{a}$ ?. . . at the end of a sentence makes it interrogative; gŭrm mět, the man has gone; gŭrm mèt à? has the man gone? If, however, there is already in the sentence an interrogative word, like wè? who? the a becomes $\bar{e}$ ? wè mèt è? who has gone? This à ? corresponds to our eh? gurm mèt à ? the man has gone, eh?

$\bar{a} \bar{a}$. . . no (Hill Angass).

ābē . . perhaps. See kābē.

àdā. . . a form of ànhā, thus, but used somewhat idiomatically in phrases, of exclamation; bi găt ādā (lit. this sort of thing!) what an extraordinary thing! mŭ chĭn răng kĕ bì àdā? how can we do such a thing? or, how shall we act in such a matter?

äk . . = ěăk, q.v.

ākŭk . H. banza, in vain, futile; gwǒ-nǐ àkŭk chě, this man is indeed a fool; găt mă yit ākŭk $k \bar{a}$, they are not in the habit of leaving it (or him) for nothing; âkŭk also = the H. liauwi =only, merely; mā por tơng àkŭk, they are merely waiting, they are waiting futilely.

$\overline{a ̈ l ~ . ~ . ~ H . A . ~ t o ~ d e n y ~=~ P . A . ~ l a ̈ ̆ n g, ~ ๆ . v . ~}$

ăm . . water (to drink or wash with), (rain =fwăn); ă-mă (or, ă-mět) yeǔk ăm, ă-jī kěn (for kěnr) mŭn lēlēe, go and draw water, and bring it to us quickly; used idiomatically 
like the Hausa rua, water'; ăm-ḡhā kěnr kā $=H$. ba manka da shi ba, it is no buiness of youl's; ăm-ḡhā dĩkā = H. ba ruankia ba; ă-dō ăm bwāp gnăn, pǒ-chð̌k fỉ gnăn dŭng, pour me out some cold water, my throat is very dry. ān . . . see ān̉hā.

ăn- . . pronominal prefix 1st pers. sing.; ăn-mět, I go, have gone, went; had gone.

ăn . . . an euphonic contraction of gnăn, me; e.g. wŭs nŭng ăn for wŭs nŭng gnăn, the fire burnt me. äng . . . see ěăng.

ànhā . ( the nasal $\dot{\mathrm{n}}$ is slightly sounded), thus $=\mathrm{H}$. hakika; ă-chĭn bì-dă ānhă, do the thing in this way; often contracted to ān or $\bar{a}$; măntă ă-tŏk shĕ̌k wŭrn ān̉hā, don't talk so quickly; mŭ rōt $\bar{a}$, we wish it so.

ār . . . a road, a path; ŭ-wŭl ār răng è ? what road are you following, or, going? ăn-pün ār wŭn=lit. I give you the road, I dismiss you =H. na sallameliu; ār gyin gyĭn, a track; ār kī, a path leading into the bush, and not to any village.

àr . . . to crawl on the hands and knees; yěm kĕ dōm $\bar{a}$ r, the youngster commences to crawl.

ărăm . . the female of a small black and white bird, the Whydah finch (?). See Dăŭlyèng.

ărgyilk . . = H. dashi, a shrub used to plant hedges with; ă-dā tăp ghŭr kĕ ärgyı̌k, go and break off the thorns of the dashi shrub; also anrgyeuk.

ăs . . . a dog; ă-yē ăs, ă-püngăn, catch the dog and give it to me; ăs kĕ worng, the praying mantis.

às . . . tooth; ās gwǒ-nĭ năn wŭrn dŭng, this man's teeth are very large. (Note, small teeth are a sign of beauty); às nyi =ivory; às po dō, the teeth are falling out (first shed- 
ding); por pŭt kě às, teething; pơ wăl dōm $\bar{a} s$, he is crying over his teething.

às . . sharp (of a knife), pointed (as a needle, peak of a rock) ; ă-nē jwăl-pănă, kē-kěnĭ às dŭng, look at that rock over there, its top is very pointed; chð̋k-ñ às kā, this knife is not sharp.

ăshrl . . testicles. See wŭm.

at . . . to bite; brǘng ăt ghüu, the horse bit the goat;

bǐ-ră (or bí-dă) mă ăt mŭn dŭng, insects bite us terribly; bì at pī, biting vermin, in general.

ăt . . to light, to tilke fire, as a torch, or a bundle of grass; y̆̌ jì kó yĭ ăt wŭs, come (said to

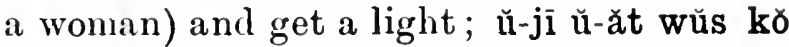
mŭ nē pì-dŕ, come and light a torch that we may see.

băğshī . a sword with a forked handle; almost certainly a foreign word.

băjămī. . a head-dress worn only by shield-bearers in war, it is a small cap with a long grass projection, and is a special mark for the hostile bowmen; ŭ-tăp gō-băjămī kū püs, look for the cap wearer and shoot him.

băk . . . to slap, beat; băk mŭn, he beat us.

băk. . to despise, contemn; băk nŭng mŭn, he despises us; to make or become small, or, less; bì-dă băk = the thing decreases; tār pro băk pro băk, the moon is waning (waxing = warn). båk. . to cut with a knife, to make a slit, to draw a line; gnăn pó băk kĕ răn kīn, I am drawing a straight line; băk gün, to cut the cheek, i.e. a tribal mark; băk tǐsh tǐsh, to cut (many) tribal marks; chāl băk, used only 
of the Angass; mă băk chāl dhřr-kěmă măntă kēn lām, marks are cut on the cheek, lest their tribe (or origin) be lost, i.e. for recognition or identification purposes.

bāl . . to get well, cure (H.A.). See bār.

bălwó . . maize =H. massara.

bām . . to snatch away, seize; ŭ-mět lēlē kŭ băm gwơ-dă dē, hurry off and seize the man.

bām . . to slip, slip away; pǒ-küng kĕ ăm bām tē, the edge (bank) of the water slipped and fell (in); gwǒ-yē-yē bām kō bār, the prisoner slipped away and escaped.

băndār . a small hemispherical basket.

băng . . a headman, such as of a gang of labourers, or a group of boys shepherding, etc.

băng . . clear, clean; bĭt băng, the morn has dawned =

H. gavi ya wayi; pĩ kĕ băng, $i d$; ă-văng nyī băng, wash it clean; ăn-pün bī băng (băng) nyī, I gave him a clean article; with chāl, a clean cheek, i.e. with no tribal mark, a ter'm of contempt.

bắng . . H. goi a, the calabash; ă-lĕ tằng bằng, kō mă lăp gwŏng, tie a string to the calabash, to hang over the shoulder.

bằng . . the heel, used generally with shī, the foot; băng shī.

bång . . an emphatic particle, lar'gely and idiomatically employed; gwǒlŏng kě yāl băng, the king has got up--(and that finishes the discussion)-said in a trial or court; even.

băng . . clear ; băng or bĭ-băng (for băngbăng), the average colour of the negro, not quite black, not fair, the complexion most appreciated by the Angass. See băng, clean; it is the same word.

băn̄ā . . welcome, salutation; ăn-măn (for ăn-mět) tŏk 
băngă kě mã, I will go and welcome them; a-tok bănga kō mŭ kăt mŭ wē, give us a salutation that we may (obtain it and) go home. bangæ. . H. ganga, the small drum with two heads, slung on to the shoulder.

băntăk a species of bean with a curled up pod $=\mathrm{H}$. liananede.

băn tüng H. hangum, a swelling on each side of the face ; tüng, or mumps? an epidemic swelling of the sides băn teüng of the face. See gurm.

\section{teung}

bär. . to get well, recover, especially of a woman after childbirth; yì bār yā? have you (f.) recovered?

bār. . . to escape ; й-nē, kĕ bär, look, he is escaping!

bār. . to become; bār tār, he became mad; bār bì-chĕ, lit. he became something (that we don't know), a term of contempt, ' he is not "all there," physically or mentally.

bărăk . see tăn.

barăng . to dig, to work.

bărăng . trouble, tiredness $=\mathrm{H}$. wohalla, !ajia, suffering, to suffer'; ăm-bărăng pǒ sheǔk-fŭ dŭng, $\mathrm{k}(\mathrm{w}) \bar{o} \cdot \mathrm{dō}$ gnăn dŭng, I have suffered your troublesomeness until I am tired; ă-bărăng bǐ lě dŭng, you have suffered much sickness. bark . . cow dung, used as manure.

bărk . play, to push a man over in jest or in a game, so as to cause him to fall; mŭn pr bark, kör dĭkā, we are playing, not fighting.

băt. . the H. majai-i or webbing made by the Angass, used as girths or breast straps; gwonI măn săk băt-dă dŭng, this man knows well how to make the webbing.

bāt. . to tie, bind, generally only of things; răn being used of men; ă-bāt brüng shr bŭt 
yōm, tie the horse to the tree; bāt shwē, a bundle of corn.

băt . . to open. S'ee bèt.

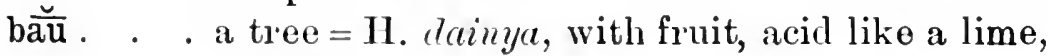
and juicy.

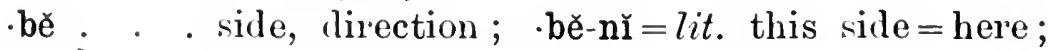
ă-jr̆ $\cdot b \check{e}-n \check{l}=$ come here.

b̆e . . . to return $=$ H. lioma; used idliomatically in many phrases; ăn-mŭt ăn-bē ăn-jī, when I die I will return-said by the man who is fond of his wife, meaning he will be reincarnated through her; to say the contrary to her is a sign of gi'eat anger'; ghǘ-dă kĕ lè, bè mă mūt, the goat has given birth, but they (the kids) have died again (bē), 7it. they have returned and died; bě kě ddō kwălp! be off with your lying clamour! bē kě kè, to turn the head aside, in contempt, so as not to see.

bēl . . shoulder; pǒtūr mă lěngăn kě bēl kěshěŭk, my breast and shoulder are paining me.

běl or băll . clear, daylight; pì kĕ běl, the sky is clear, as after a stor'm.

běl or băll. a musical wind instrument (H. kworkvoro) blown down lengthways through one end; běl păs, a musical pipe made of a reed.

bĕl . . the hump of cattle, H.A. = dŭngŭl P.A.

běl . . to bore, to pierce; běl bŭt yĕr, he bored a hole into the granary.

běl . . sense, r'eason; yěm-ň̆! běl ḡhā kā! this youngster! you have no sense!

běl . . . to light; ă-bĕl wŭs, light a fire.

bělm . . to lick; bělm kün, to lick salt; ğhü bělm yěm-kěnı̆, the goat licks her kid.

bēm . . to throw, to shoot; bèm ḡhk, he threw a stone; ăn-bēm nyı̆, bĭm, I threw (a stone) 
and hit him (biff!) hard (brm, particle). A stone is thrown at a cow about to be slaughtered; if this is omitted the rest of the herd will get diseased, or be unable to produce; bēm is generally used when one thing is shot or thrown. See chār.

bém . . to scolch, but only in parts; see lèt; wŭs bēm kă bēm bēm, fire has scorched it here and there.

běn . . the gall of the stomach $=\mathrm{H}$. data.

běn. . . broad; fwŏr běn dŭng mă lē yōm mă děl rŭ $k_{a}$, the river is too bload for a bridge (tree) to reach across.

b běñ . See bě.

bès . . to dally. H.A.

bès . . to spit. Śee bĭs.

běs . . . in pŏ běs, the shin bone.

bět or băt to push, to butt, of rams, etc.; any sort of shoving without piercing.

bět . . . to open; bět pǒ lū nyì, open the door to him. bět . . broad, for běn.

bì . . a thing, article, affair $=H$. abu.

.bi . . H. fafe, to burst from ripeness, as a calabash, or a hatched out egg; ès kì kè bbì à ? has the egg burst? i.e. hatched? $\mathbf{k i} \cdot$ bì ès săr = the hen has hatched ten eggs ; to split wood, as with a knife, etc.

bi-bŭt-rōt H. bukata-l $r a i=$ the necessities of life $=$ lit. a thing the inside wants.

broếr . origin, foundation, beginning; the rump; the bottom of a tree or hill; the east, as being where the Angass came from, and whither they look as the beginning of all they know; bĭdér kè shēuk tǒk răng è ? what was the origin of the discussion (or talk)? 
broérkăká ancestry, lineage $=H$. zuria ; ancestors, elder's of the same race; ă-năng brděrkăkā-nū kō mă jŭ-dŕ, call our elders to come here.

bì-lì . . a tree, H. bi ni da zugu; fences are made of it; also oil for smearing the body.

bùltā . . the Filani; brltā nŭng, the cow Filani.

bìndū . . to swim; ăm-dă găm fwŏr dŭng, ŭ-děl shř-n bindū, the river is quite full, cross it by swimming.

bip . . H. gebaji, a large water animal with a short tail ; bites severely; otter (?).

bì-ră . . for bù-dă, the thing; bĭ-rā-mă at mŭn dŭng, the things bite us dreadfully (of vermin).

bĭs or běs . to spit; bĭs lĭ, to spit out saliva.

bǐs . . sometimes beus, wickedness, badness, evil ; ghā bì bĭs, you are a wicked thing (term of abuse); chĭn sheǔk bìs gnăn, něn-fănă kĕ yē ny̆, he has sinned against me, God will punish him for me; lit. my Almighty will seize him.

bĭsăk . . H. tuba, repentance; ăn-lā bĭsăk-ḡhā băng = I accept your repentance, i.e. the incident is now closed.

bit . . . the morning, dawn; just before sunrise, but after pǒ tăm pī; bĭt măng=the day has dawned, P.A. (H.A. bĭt băng.)

bit . . a horn prepared for cupping operations. bǐt . . . a tree, H. kawo.

bóğhŏrŭm . the Burrum people of the Kannam district.

bŏk . . H.A., repentance; bớk ă bớk ă bớk = I repent, I repent.

bǒk . . the brilliant red seed with a black spot at one end, used as beads to make headgear and necklaces for the 'braves' of the tribe $=$ H. idon zaliara.

bǒk. . a species of bean. 
brkā or H. agazere; the hot month at end of the rains, brōghā about October; the sunstroke season; possibly bơğhā may mean 'it sunstrokes you.'

bøŕ . . . an enclosure, as for cattle, a stall for a horse; bơn kŭm, at Ampier or Naza only=the sacred enclosure which no one enters except the king, or some authorised official; also, borng.

bong . . the large-leaved fig tree = II. gainye liun'hi.

bong lit . the bong tree of thickets, slightly different from the bong which grows in the open.

brüng . . pony, horse; brüng-dă rơk gwŏ-dă= the horse has thrown the rider.

$\mathrm{bu}$. . a grass used in making mats and door curtains $=\mathrm{H}$. dersh $i$.

$\mathbf{b u}$. . . to bulge; y̌t $\mathbf{b u}=$ bulgy eyes.

bŭğhmŭn . a squiirrel; bŭğhmŭn kè lăng teūng, a squirrel leaps about in a tree.

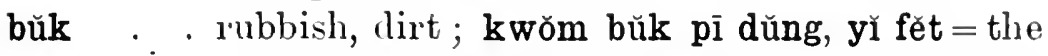
porch is very dirty, sweep it (f.); accumulation of dirt, of which the main feature is old leaves and broken grass; pī bŭk=the place is dirty, wants sweeping; the second clearing of the weeds, etc., on a firm $=\mathrm{H}$. maimai; grass cleared and thrown away; bŭk shĭt =old thatch to be discarded; ă-bŭk manr = clear the far'm of grass.

bŭl . . a particle; also used in a comparative or superlative sense; mïr pēt shăng bŭl= either, itiri oil is good indeed; or, itiri oil is the best, or better; also in the sense of 'moderate'; bŭl kã $=$ it is not vel'y much $=$ H. da dama; rit bŭl = it is very good, fairly generally used in answering sentences; mínă kè bē rît bŭl = mine is indeed better (than yours). 
bŭl . . the dove $=$ H. kurchia .

bül . . a tree = H. zurma.

bŭm . a cap $=$ H. fula; gwơlơng mă găk mă lăp bĭděr pŭs, mŭn kŭk mŭ lăp bŭm pyè găk = only kings put on the red cap, we subjects wear the white one only.

bŭn. . . to pick up one by one, choose; à-bŭn kō nĕ à-rōt $=$ choose what you like.

bŭn. . a sore, due to a rotten tooth, which eats a hole through the cheek, and appears on the outside.

bŭp . . . fish; jěb-mă yäk bŭp shĭ shăng=boys catch fish with a net.

bŭr . . . sand, dust; bŭr wŭs = the ashes of a fire, also the spot where a fire has been.

buráa . an exclamation denoting that some thing sought for, especially something of importance, e.g. a lion's colpse, has been found = eureka!-used several times over; bŭrá! bŭrấ! bŭrá !

bŭrk . . soft earth, dust or mud, which, when trodden on, leaves footprints, etc.

bŭrk . . meat which has gone bad, H.A.; bi-fănă-da bŭrk, ăn-chĭn răng nyē? This thing of mine has gone bad, what shall I do with it? (nyē for nyı̆ ē ?).

bŭrshī . . vermin, especially a tiny maggot from an egg (?) laid by a fly called shī wēr; it bites men; prisons are nearly always verminous, hence, mět kě gwŏ-dă lŭ-n bŭrshī = take the man to the verminous house (i.e. to prison). bŭshăng . the bowels, H. hanji; bŭshăng kĕ mwĕn kĕ gnăn = my bowels (i.e. hunger) cause me to wander. See wàlīā.

bŭt . . H. chiklii = the belly, pregnancy; nyì kĕ bŭt $=$ she is pregnant; disposition $=\mathbf{H}$. halli; 
ăn-măn bǔt-kěnī kā, I don't know what sort of man he is, i.e. his disposition or habits; dắng shr bŭt = to crawl on the belly (H. ja da chilkit).

būt or büt any small round article, like a marble or ball ; büt also the big roundish stones used in making walls, etc.; a round lump of earth, etc.; büt gnăn kwăn-y $\breve{\text { eúk }}$ = make me bricks that I may build.

būt. . all; not often used in this sense by itself; yăk shăk $\breve{u}-j i j ~ b u ̄ t=$ choose among yourselves, and come all (e.g. in fives, etc.); ké būt, or kă būt = the whole, complete; gō ké sě kwơp, kè păn yíl kě būt=he who has the spear, owns the whole country.

bwăk . . a dance at death, either of a king or a leopard, pig, etc.; and also of any man or boy, but not of a woman or female, which is mèp.

bwāp . . H. lafia = health, well; ă-jī bwāp à ? do you come well? bwāp gnēt = quite well (thanks).

bwāp . . II. sainyi = cold, damp; pús kě bwāp = the sun has got cold, i.e. af ter 4.30 P.M., or so.

bwāp . . raw, uncooked; kŭdĩ bwāp=it is still unripe.

bwăn . . all edible leaves, vegetables; chŭk bwăn= the woman's kitchen knife, not carried on the person; kwămtăk dăp chŭk bwăn, kō yăng sheük-kěnĭ-dí = so and so took up her knife, to kill herself; women sometimes commit suicide with it if their infant dies and the knife is not put away out of her sight; bwăn $\mathrm{gwa}=\mathrm{H}$. wavan gona $=$ the large leaf of the calabash plant; lú bwăn= the wife's cooking room.

bwăn . to pluck fruit, leaves, etc. 
bwāp . . see shē̌k, wet.

bwär . . H. bulala = sjambok, or whip; at times pronounced nbwār.

bwār . . a lion; bwār pŏ păt kĕ $\cdot$ dō $=$ the lion is roaring.

bwèr . . the yam = H. doiya.

bwēr yōm 11. rog", a vegretable.

bwēr . . to scoff, laugh at, despise; bwèr kě pì, whispering, in a bal sense; backbiting.

bwin . . the small of the back; the hips; kă bwin = after, behind; pr bwin = the waist garment of women, made of string.

bwir . . the Angass name of Kabir, which we have derived through the Hausas from gŏ-m-bwír $=$ the people of Bwir.

bwìr . . to upset, pour out, spill, as water, or grain from a sack.

bwǒk . . to do again; dēr ăn-bwǒk = I'll do it again to-morrow; dēr ăn-bwǒk zā kā = I won't do it again to-morrow (or, ever).

bwǒk . . the name of a grass (when young, birds eat the roots).

bwŏk . . see under lōm.

bwǒp . . a he-goat $=$ H. bunsuru.

bwǒp . . the red earth $=$ H. lioiya, used as a body decoration.

bwǒt . . to accompany, escor't; kĕ dōm mět băng, ănbwōt nyī, when he actually (= băng) starts I will accompany him.

bwǒt . . to release, to let go, to let drop; ă-bwŏt nyī, let him go ; ă-bwǒt $\cdot$ dō nyì, shout out to him, lit. let the voice go to him, or release the voice to him; bwøt wŭr, to leave the breast, to be weaned.

bwǒt . . quickly, at once (H.A.), or vwǒt; ă-yāl bwǒt, get up at once! 
bwot . . to lay, to place, to spread out; bwøt $g w \varnothing k$, to lay a trap.

byār, or a shrub with long straight thorns, with white

teūng flowers of a jasmine scent, and black sweet byār edible berries growing in clusters $=H$. chi zaki.

chā . . = chè ā ? ākăn chā or ànhā-n chā =H. lio ba halika ba? Is it not so? Frequently used to convey a doubt; mŭ mèt-n chā ? can it be that we are going? i.e. we don't know yet whether we shall go or not.

chăděr. . a mistake, error, forgetfulness; ăn-chădèr kě bī (nè) ă-lěngăn dōn-dōn, I have forgotten what you told me yesterday.

chăk . . to pick up and collect, of small quantities, such as articles fallen out of a load; chăk bì-sē mŭn, kō mŭ sē, collect food for us, that we may eat.

chăk . . to shoot. See p. 138.

chāl . a cheek; chāl tŭm, or chāl tŭkŭlŭn, a cheek without any tribal mark, a ter'm of abuse; chāl băk (or băk băk), a cheek cut, i.e. with the tribal marks; bì chāl, a horse's halter or head rope.

chăl . H. randa, the largest sized water-pot. chălirm . a female surname. See sūwā and gworntūr. chăm . . to touch, taste; but especially to feel or grope in the dark; chăm kè leús, to taste with the tongue; chăm-kenñ̌ shăng, its taste is pleasant.

chăn . . to cut $=\mathrm{H}$. yenkia; mă chăn nŭng, they have slaughtered a cow (a cow is killed by cutting its throat). See chēn.

chăn . . to remind, dēr ă-chăn gnăn, remind me tomorrow; ăn-chăn bŭt-nă $=1$ will remind 


\section{ANGASS MANUAL}

my inside, i.e. I will remember; chăn bi(t)n bŭt $=$ lit. to remind the affair inside, i.e. remorse.

chăn . possibly a secondary meaning of above=interpret; gó-chăn, an interpreter, or better, gǒ-chăn sheūk tǒk ; interpretation; ăn-sūn, ă-jī chăngăn kět kět, I dreamt, come and tell me its interpretation carefully.

chăn . . in gwðð-chăn, an amusing man.

chär . . to shoot at; in H.A. also to throw (stones, etc.); mă chār gwŏ-dă, they shot at the man (but did not hit him); mă pūs gwǒ-dă, they shot (and lit) the man; chār has the sense of shooting or throwing several things, lŭk and bèm, generally used of only one.

chār . . to want a thing very much; ăn-chār bī-dă dŭng, wă dăp pān è ? I want this thing badly, but who will give it to me? i.e. how can I get it?

chărn . H. gara; the white ant, the large species. See tēzū.

chä́s or the H. baure, or large-fruited fig tree.

chwằs

-chĕ . . a suffix $=$ a certain ; gwǒ-chĕ, a certain man; b̆̀-chě, a certain thing; kō-chĕ, a certain one; kō-chè kō-chā, one's the same as another, they are all the same.

chěăng or to go off in a huff ; nyī kě bě yĭt-ğhā chěăng, chằng he returned from you in a huff.

cheăng or clitoris. H.A.

chằng

chěbār. . spur ; ğhā kě brüng, ḡhā kě chěbār kā, kō à-sě năm kün dỉkā, to ride a horse without spurs is like eating meat without salt (the horses being very lazy). 
chèlè . H. tukunia, a pot; chělě-fănă-dă rīt dŭng, dảng tằng mŭn kā, our pot is very fine, but it does not increase. 'tuo' (a species of cooked food).

chělơng . a sling, for stones; jěb mà bèm shr̃-n chělorng, the boys hurl (stones) with the sling.

chěn . . to cut, of small things, but not used so much for wholesale cutting as chan ; thus chen tă̆ng, he cut a string, but chăn tắng, he cut through a mass of strings.

chen . . the very large hoe, the size of our spade; it has a long handle at right angles to the hoe, and is used with both hands, something after the manner of a pick.

chěn . . a hedge, a fence; chěn pð̌ kěn, an enclosure.

chěn . . to follow, to surround; mŭ chěn nŭng shr

kem, we followed (i.e. surrounded) the space with cactus; gõ-wăt sū, a-chěn shĩ-kěnĭ, the thief has fled, follow him (lit. his feet).

chèp . a wing of a bird.

chēr . corn which comes to a head, but does not ripen. chèt . . to cook, generally; to smelt; pī chèt shāl, a furnace. See fŭk.

chět . . to roof $=$ H. jimka.

chē̌k or a beating, thrashing; chłmā-ḡhā-dă à-chük è ? chük what makes you beat me?

cheung . chance, opportunity (?)

cheung or fractious, to be too much for ; yin kè tã, mătchrn dă cheūng, bě trong, the remedy for refusal, if a woman becomes unmanageable, ignore her (sit tight); gwớ-dă chěung kě pì dŭng, pin yil, the man has troubled everyone, and has upset the whole country.

chěwe . . H. shafale (a wolf ?); it kills sheep, etc., and is known to have killed men among the Angass. 
chěwě . black and white; black and tan, piebald, parti-coloured.

chì . . H. chinia, the thigh.

chǐbứt . water oozing out of a rock.

chǐbwŏlng H. tscula bush, has a red edible fruit.

chīl. . . a wound, a bruise, a sore.

chim or anything found (taken at once to the king);

chŭm kin pyēngăn kwăn-kăn (kăt-n) chrm, I was lucky and found something. H. chintuce.

chı̌m . any black ore. See tĭm.

chĭm . H. dammo; a species of large non-poisonous lizard, of a light stone colour; it is edible, and its fat is considered an aphrodisiac.

chĭmīr . . a stork = H. shamua; mă jŭ, tār bĭ kwóp, (when) they come it is the season for sowing. chĭmā . for chĭn mē à ? lit. it makes what (to you)? i.e. what makes you (do this), or, why?

chīn . . to drive away; mǐs-nă chīngăn, my husband has driven me away. In war, to drive off; mŭ chin mă, we drove them back, away, off; and thus, to prevent; gōl chīn wŭn kĕ wăt, the law drives you off from, i.e. forbids you, stealing.

chĭn . . . see chĕ̌ng, to be exceedingly troublesome.

chĭn . . to do=H. yi; also used idiomatically like the latter; chĭn yī fīr =ya yi shekara hudu; kō-nı̆ chĭn kō-pănă, wa-n-nan ya yi wa-nchan; ă-chĭn bŭ-dă, do this.

chřng . . small heaps, or mounds.

chrng or H. gagara, to be too much for; chüng mŭn cheung kesheǔk, he is too much for us all. or chüng

chĭnĭ . . to-day; chĭnĭ kĕ dì-dēr mă něn, to-day and to-morrow are God's.

chip . . a bag made of string (shaped like a tuliunia, or water pot), used to hold grain. 
chip . . see chwip.

chïr . interpret; gŭrm kě chïr sheūk, bě gō-kwălp, the man interpreted, but gave a lying interpretation; to change; chïr shăk, to do something, such as hiding one's cattle, so that the rest of the family do not know where they are, e.g. in avoiding paying a debt, or confiscation ; transform ; interpret ; mă chīr ko bì sơng sơng kădăk, they did not change it into anything else; gwo-da chīr bǐ-che mŭn tăng-dărăng, the man became metamorphosed, and was lost to us; to turn, or roll over.

chir . . mimic warfare, when all the motions of fighting, avoiding and warding off arrows, etc., are gone through; a sort of lance done at the festival, mǒs-tär at Dawaki, and at Mors-lūn at Ampier; mimic motions of shooting a lion, etc.

chīr . . in chīr pó tōr, vertigo; chïr pǒ tōr kō măn pī $z \bar{a} \mathbf{k a}$, he has (such) giddiness that he can recognise nothing at all.

chìt . altogether, completely; mă mèt chīt, they have gone completely, not one is left.

chĭt . the same; $m a ̆(n)$ chĭt $=m a ̆(n)$ găk, they are the same; chit chit, H. dai-dai, the same; ŭ-mět kě chĭt, go together.

chōchōt, a children's game = shăng shăng. chōtchōt

chřk . . the neck, throat; chơk sōn rī-rìt, a long neck is beanty.

chðkr . particle; absolutely, completely ; fī chðkr, it is completely dried up; păs gåm dolong chokr, the arrows completely fill the quiver.

chōl . . a sentry, spy, secret service agent; $а$-chōl pī 
mŭn, keep a look out for us ; go chŏl, a spy, sentry.

chōl . . the locust proper, the devastator. See gwǒk; chōl-dă sè shwē mŭn dŭng, the locust eats up plenty of our coru.

chöl . to make investigations on the quiet, to visit; pār-chĕ ă-chōl mŭn kä ? dirln't you enquir'e after us the other day? or, won't you visit us some day?

chrm . . H. aguada, the rock coney.

chōn or a finger or toe nail; claw of beasts and birds;

chön chōn wŏng gŭrnā, the piping of a hollow reed, explained to the women as coming from the nail of Wong Gurna.

chóng or a food grain = H. damro.

chwŏng

chōr . poverty, straitened circumstances; astonishment, perplexity, worry ; gwŏ-nĭ chōr dŭng, either (a) this man is very poor, or (b) this man is very worried, or astonished - astonishment being akin to fear; gŏ-chōr, a poor man; gwŏ-ni chōr ăn (for gnăn) dŭng, this man annoys me very much; gŏ-chōr kè tăp pĩ tŏng kä, the poor man does not get a place to remain in; sometimes chŏr; cf. H. chiri.

chōt . . to roll up; chōt lĕn, he rolled up his mat; sōm chōt, a curled horn; to roll round; mă chōt păs shĭ pēr năm, they bind arrows with flesh sinews.

chŭk . a knife, especially the hip knife carried by every man; chŭk vŭm-dă, ăn-săk bī shì shĕ̌k, dăng kō nyĭ às, the rusty knife, when I cut something with it, becomes sharp.

chük . . to beat, pound, as in a mortal ; to thrash 
with a stick, to thrash; chimā (= chín mè à) gahā dă ă-chǚk ē? what has she done that you thrash her? (or, the child), lit. it makes what to you, that you beat (me, him, it, etc.)?

chŭm . see chřm.

chwāl . a smooth stone, used for polishing, such as the glaze on the walls of at house. See lēzù.

chwil . H. makankari, a shell-fish (?) found in river's. chwip or a white earth, used to smear on the body at chip festivals; also put on walls of houses. chwï̀ . . a snail. See kwōdì.

dă-, f. nă- prefixes to words, which then become proper names; thus dă-fwăn (or more usually gofwăn), f. nă-fwăn=lit. one born in the rain, or rains.

dă . . used with the personal pronouns=too; ğhā dă-ğhā ă-mět, you, too, go.

dă . . H. sai, in such expressions as dă bē dă-ğhā, sai ka liomo = except, or, until you return.

dā . . H.A. horse; dā tĭp, a black horse.

dā . . . to go ; ă-dā tĕp ğhŭr kě ărgyǐk, go and break the thorns of the dashi (H.) tree.

-dă. . . a suffix; our very definite article 'the,' or' 'the particular' ; măt-dă ăn-ně, sū, the (particular) womin (whom) I saw, ran away; not uset unless the object or subject meant is definitely referred to ; thus, brüng $=$ a hor'se, or, the horse, but brüng-dă, the particular hor'se we have been speaking of.

dăb. . see dăp. 
dădǔtt . a very small bottle-shaped calabash; any small receptatcle; mŭ năng gwŏ-yīn kĕ dădūt kō mŭ yē gwō-nē-n-djī, we called the medicine man that we might capture the wizard ; the test medicine for witchcraft is put into a dădūt.

dăk. . H. darra, a game.

dāsà . . = běl, a dance, with pipes; everyone, oll men and all, turn out, with all the finery and ornaments they have.

dăl . . to swallow; ăn-dăl bĕ dār gnăn fŏ chơk, I swallowed (it), but it stuck in my throat.

däm or thick growth, as of hair, grass, etc.

düm

·dằm . . lust; pì ·däm dăng nyī fŏ tălìt, on account of lust she committed adultery; desire. See -dĕm.

dăm or any wild grass; sĭt, shwăt, părp, tōt $=$ to děm pluck (of grass). dăm . . stick, staff ; ă-dăp dăm ă-pān kwăn-wŏk sār, pick up the stick and give me that I may hold it; dăm nyı̌r, clitoris.

dăm . . to jump; ă-dăm jük, jump strongly.

dămǒk. . a species of calabash, with very rough rind like hobnails; nŭng dămǒk, H. lijaji, a cow with short horns lying close to its head, instead of spreading; and it has no hump. (H. liululutu liurzunu.)

dändän . the reed harp of the pagans.

dăng . . a tail, of beasts or birds, etc.; dăng kwān, Orion's belt, lit. the tail of three: the first star is tără, the barewa gazelle, the second ăs kă shì-kĕnĭ, the dog on itśs trail, and the third is gwŏm-bī ăs kă shī păt, the ownel' of the pursuing dog; dăng kě lăng, a tail hanging down, a whip, bull's pizzle, etc., 
also the fruit of the (II.) dorma tree, which is long and hangs down.

dăng . a particle; when commencing a subordinate sentence $=$ but, then, when ; myirm yāl sìt ăm-dhĭr, dăng wŭs sě pī kět kět, the python arose and entered the water, then the fire destroyed the place utterly; frequently reduplicated, dăng dăng or dăng dăk; mă yìt gnăn dăng dăk, let people only leave me alone; ăn-tơk gōl kā kō kīmī mă jí dăng, I shall not juclge (the case) until the witnesseses come; mă pūs shĭ păs yīn, dăng kě bāl, they shot him with a poisoned arrow, but he will recover; mŭn pó tē kă shăk, dăng băkăn (for băk gnăn), we were falling together, when he stabbed me. See uniler. kiăk.

dẳng or to pull, to dranw, to stretch out; dắng ār $=$ děăng H. ja hainya, lit. to pull the roal, i.e. to guicle; gwor-dẳng ār, a guide; mă dẳng mẽ kwăt è? H. mi za su yi liua? what will they do now ? dắng kăngðrr, to snore; dōn dắng bě dằng sheūk, dăng shāl dăng bě dăng sheük kā, rubber is stretchable, but iron is not.

dăng dăng a tree like the H. baure, or figr.

dănĭ . one; kwǒ-chě děl dănĭ kā, one does not exceed one, i.e. the other; dănĭ dănı̆ chā? mă yĭt găk kěsheük kā? are they not one? aree they not the sime thing?

dănkāli . the sweet potito); borrowed from the Halnsil. dăp or dăb $H$. dauka, to lift "p, (arYy; mŭ dăp wŭs-n shăk kā, we don't take fire to each other, i.e. we are not friends, on speaking terms.

dằp. . see děp.

dăp-n-dăl the minute black biting insect (wrongly?) 
called the sind fly; the smaller H. muliumuliu.

dār . . attempt, cndearour, comting trouble in the cflort; där dùng, he malle a great attempt, practically = bărăng dŭng; = H. aniya, a good attempt; ŭ-dār kū mèt, pī sōn dŭng, "buck up' and gro, the place is far off; gwŏ-dār, a zealous man, a try-er ; to try ; mă dār (kō mă) măn kě shĕ kāk, they do not try to get used to it.

där . . to go haltingly, not flom permanent lameness, but from a temporary disability, such as a sprain or a cut foot; to limp.

dār. . to stop, stay; yĭs dār nyī kă (n) gwoongwŏn, the bone stuck in his throat; ă-dār, stand still, or, stop! as when a man is told to stop his talk; măt dār, a barren woman, or l'ather, one past child-birth; to stand upright; mă păn dăm pī dār, one keeps a stick to stand upright, i.e. for support; dār kām kām, stiff, unbending ; kwŏng-sār-fănă dār kām kām, kĕ gŭrng bĕ gŭrng kā, my finger is stiff, it will not bend.

dăr or năr used with kēe, a head=H. bissa lian; tē dăr kē kĕ lŭ, he fell from the top of the house.

dărm . . bark of a tree.

d $\breve{a u l l y e ̆ n g ~ . ~ a ~ s m a l l ~ b l a c k ~ a n d ~ w h i t e ~ b i r d ; ~ H . ~ z e l e i d u ; ~ f . ~}$ ărăm; it has two very long tail feathers, and is accompanied always by several comparatively dowdy females. (The Whydah finch?)

düulyĕng . a pony with a blaze, and four white stockings $=\mathrm{H}$. clanda mai fari biar.

dé . . a bowl, a calabash; dè shì, the bowl of the foot, i.e. a hor'se's hoof; dē yōm, a wooden 
bowl; dē pill, a peculiar elongated large calabash, filled with grain and given as a present to briles; dè pè, the tortoise shell;

dè kŭr, used by the gó-pè or diviner's.

dè . . . a superior. See dídè.

dě . . excuse ; dè-fā ntē mē ? whit is your excuse?

dë-fănă dí gnèt, certainly there is my excuse = certainly I liave an excuse; dè-fănă dì kō-răng! whỳ shoulıln’t I have an excise?

dè . . userl with kè, a spring of water $=k e \overline{-}-n$ dè.

dé? . an euphonic form of è? when the latter is precederl by a vowel, especially a long ' $\mathrm{e}$ '; gwǒ-dă chĭn mē, dăng kě lă yē dē? (for. yè è?) what has the man done, to shont about? mè yěl dè dē, what has split the callabash, for, mè yěl dè è ?

dèl . . to cross, to pass by so as to get in front; to surpass $=H . f i ;$ mŭ dĕl fwŏr, we crosised the river; ă-dèl pŏ-kin, pass along to the front; brüng dèl ğhü (shĩ) kām, the horse surpasses the goat in strength, i.e. is stronger than the goat; děl kě pì, to have the sovereign power, authority ; dèl kè-kěnu, he overrides us; děl kě pī kě mărăn kě chĭn, kō mă gǒ-wǒk kā, the authority of the mistress is not so great as that of the master of a house; dèl bè děl (kã), (min)fordable.

derm . to surround, to prevent escape, to hinder, prevent; ăs mă dèm pī nyī, the dogsi surrounderl him, lit. the dogs prevented escape of the place to him; also dem.

·dèm or longing, desire, lust; shwē kě bāl pī, năm bì -dẩm dẳm, coln keeps life going, meat is a matter of longing, i.e. luxury; gwǒ-ň̆ pó $\mathrm{k}(\mathrm{w})$ ăt 
dăm kĕ măt-ňr, this man is lusting after this woman.

děm . ğlısss. See dăm.

děn. . to place, put down; ă-dèn bì-dă mwă dr̆, put the thing down for them there; Něn děn yil kěsheurk, God made the whole world; bi-den-dèn, an article placed in charge of some one; à-děn dù = put it down ; děn bŭt, to put down in one's inside, to intend; ăndĕn bŭt-nă tĕ kō ăn-yāl chĭnĭ, dăng ăn-yāl dĭkā, I intended to start to-day, but have not llone so.

děn . . avirice, greed, covetousness; ă-děn-děn lādā, ă-rōt mă, gŭrm-mă chĭn mē ? you are greedy (H. ka chililia rouca), why do you like worrying people? lit. you like them, but what shall people do? gwŏ-dă dĕn-děn, a stingy man; gwŏ-děn mă mŭk ăm-kĕnī kā, a stingy man does not give away his water (even).

dĕn . . to prevent; ă-dĕn mă, stop them; ă-dĕn-děn dŭng, ăn-dĕn ğhā dì pĕt, youl are very greedy, but I'll stop you!

děnděn . see dä̀ndä̀n.

dĕng . among the Suras = family, household $=\mathbf{H}$. iengi.

dĕp or däp the $H$. dunya tree.

dēr . . or dĭdēr, to-morrow, and so, the future; mă lă gnăn chĭnĭ kā, dēr mwă lă kā, they have not caught me to-day, and they will not to-morrow (or, in the future, ever); pĩ mŭn dĭdēr dăng mă văng chělě, one washes the pot for to-morlıow's fool; yī dì-dēr-chĕ, in times to come.

dĕs . . a man, a male; frequently used like the Hausa jema' $a$, a group; mŭ kăng dăğhă 
děs, we have collected in a group; děs-kām or dìs-käm, q.t.

dhyr . H. vurin $=$ Fr. clees; at, or to, the place of;

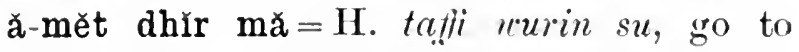
their place; à-bè dhrr gworlorng-dhır, go to the king again (for the second dhrr, see $s e q$.$) ; race, lineage, relationship ; mŭn dhłr-$ $n \bar{u}$, we are of the same race; $m(w) \grave{a}$ dhirr kè mă dó nyì, he is of the same lineage as they ; ă-mèt dhĭr-kěni (but not dhĭr nyī). or dí-dhrr, go to his place; mŭ chěn dí-dhirr, we follow him (see dŕ); ða-chłn dhřr-nă, do it for me; ă-mět kě ní dŕ-dhr̆r, take it to him.

-dhĭr . . a suffix to verbs, denoting a recurrence of the action, again; ăn-nē mă mă mět-n-dhřr, 1 see them going off again.

dhǐrm . . a woman's room where she stores her household apparatus, cooking pots, etc., but not the grain.

dí . . . = dhĭr in all respects; it is also attached to the latter, e.g. dì-dhĭr = H. anurin; ă-mět dĭdhĭr, go to him, only used of a man; to go to a woman =ă-mèt dhr̆r pà-dă, where the woman's name is unknown or unmentioned; ă-jĭ dí, come to the place; ă-lăp dí, put it down, or in its place; in this last use of dí, the dí is very short, and is almost ' $\mathbf{d}$ ' pure and simple, e.g. ă-ji-d; also userl as a prep.=H. ya, to, or for ; dí mă, H. gareśn, to, or for, them; ă-chrn dhirr-nă, or', dr̃-nă, do it for me; ăn-torng dr măt-dă, I stayed with the woman: mă lé dro, they pouren it out there; this dir at the end of a sentence occurs with great frequency in circumstances which it would be hard to 
trinslate. It is entirely idiomatic, and may in most cases, as in mă lě dŕ, be left out, without injury to the sense; it can be translated by 'there,' or ' at that place.'

dŕ . . Hausa alirroi; ăm dì à ? ăm dí, is there water? there is; it is not used by itself like alizoi; there is = nyĭ dú; (dŭkā, there is not, 11 . balun, is used by itself, like balu) ; ăm dı̆ à? ans. ăm dĭkā, ol' dìkā = none; yŭt dĭkā, ă-nē pī $\mathrm{ka}$, if you have no eyes you cannot see = H. ido labu, ba lia gani uri ba.

dĭ . . used as the accusative, where one would expect nyī, but as the latter is also the dative, dí is used to avoid ambiguity; ăn-tū dí, ol', ăn-tū $n y \bar{i}=I$ killed lıim, but the latter can also mean, I killed (it) for him ; perhaps this dì is connected with the $d \check{i}=$ dhĭr (1.v.); though d̆ is used just wher'e we might expect an accusative, it quite possibly is frequently no more than a particle to round off a sentence; e.!. ăn-shīt ğhā kō ă-măn chĭn-kěnì dì, I will teach you, so that you may know its doing (i.e. how to do it), where the dì is untranslatable. See its frequent occurrence in the tales in the Grammar.

dìdē or dē the title of one's immediate chiefs, and of those whom he follows up to the highest; a title of the highest respect; dĭdē kě lī băng =the king has spoken clearly; dĭdē yĕ ǔk tŏk băng, mŭ lì mă kwăt? the king has spoken, is it for us to speak again?

dìdēr. . see dēr.

dǐdit . . short, small, ă-mwěn dǐdit, ğhā go-wăt ā ? you go very quietly (small small), are you a thief? See dĭt. 
dík or dük to deceive $=$ H. rule.

drkà . . compounded of dĭ, there is, and kā, not = there is not, none $=\mathrm{H}$. balue.

dǐkăbī . (probalbly of foreign origin), a stick for beating eloth.

dîkāshī . the H. angulu, the 'ommon vulture; ă-chin dìkāshì-dă, drive a way the vulture.

díkür. . one of the Wongs, the bogeys (see wong); dressed in shăng nănyin leaves; the women are told it is a male. See worng yim.

dil . . the wattles, etc., of male birds, especially of cocks.

dilm . . a horse that cannot go fast. II.A.

dĩt . . short; gwo-dĭt, a dwarf ; dĭt dŭng kě děs-mă, he is the shortest of the lot; sheuk torkkěni dĭt, liis talk was short; mă (kă) tŏng .bĭ-nĭ dít, dăng mă (kă) yāl, they stayed here a short time, then they went (arose). See dĭdit.

$\overline{d j a ̄ a n ~ . ~ . ~ s e e ~ j a ̄ n . ~}$

djāp . . a swamp, marsh; pi djāp kě rìt shwē kā, a swamp is not a good place for a corn far'm.

$\overline{\mathrm{dj}} \overline{\mathrm{j}}$. . . an idiot. See $\mathrm{j} \overline{\mathrm{i}}$.

$\overline{\mathrm{dj}} \mathrm{il}$. . . darkness due to thick growth of trees, bushes, ete.

djìm . male generic name for boys of Kudum; f. =

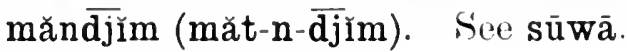

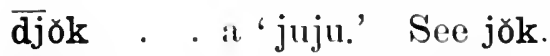

$\overline{\mathrm{djök}}$. . an ivory armlet, worn only by chiefs. See jwăk.

$\overline{\mathrm{dj}} \not \mathbf{k}$. . the $:$ rmupit = lŭnāp.

$\overline{\mathrm{dj}} \mathrm{j} \mathrm{k}$. . to fill up by pressing lown the contents, to fill full.

$\overline{\mathrm{dj}} \not \mathbf{k}$. . to poke, or tickle, especially to tickle a girl. See jok. 
$\overline{\mathrm{djō}}$. . see jōm.

$\overline{d j y} \not t$ or to throw down violently as in wrestling (?).

djyăt

dō . . a difficult word; it corresponds in most cases to what is called in Hausa the verb 'to be,' viz.: ne, lie-e.!\% nyì dō gwŏlöng $=s h i$ ne seriki, this is the king; nyì dò dă $=$ sti $i$ lie nan, that's it; but it is more probably merely a particle, or perhaps a suffix; ănyāl dăng dō $=\mathrm{H}$ a a an tashi ne, very well, I'll get up (and go); kă shī kě kō-dă dō mă mert $=$ after this they went.

.dō . . (a rather explosive d), a clamour, shouting; a sound; a complaint; mă bwŏt dō, they are shouting; it includes the lururua or war-

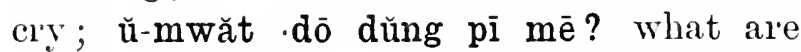
you clamouring so much about? ăn-fwŏt -dō-chĕ, mě dè? I hear a sound, what is it? ă-mět kě ·dõ dĭ dĭskām-mwā, take the complaint to the elder's; dōo-dă shăng shĕ̌uk gnăn, the sound pleases me.

dō . . . to ladle, pour out; dõ wēr gnăn bắng kwăn mèt shǐt, pour me some gruel in the calabash, that I may go off to work; to spill, be spilt; to pour; lě teūng pó dō=the fruit of the tree is pouring, i.e. is falling (from ripeness).

dŏ . . . trouble; weariness; mŭ wāl dō kě ghă găk, a form of salutation = we simply weep over your trouble; ŭ-tēr bāp, kŭ shăng nyǒk dăng, dō wŭn dŭng, sleep a couple of nights, rest well, you are very tired.

dork. . . yesterday, formerly=H. da, it takes the ordinary as well as the past narrative tense, thus, 'before he died,' or 'before he liad died' = dǒk dă bē müt kā, or dǒk dă bē kă- 
müt kā; lit. formerly, he liad not died; dǒk gwã-mă mă (kă) jī kã, ngăss-mă mă (kă) nē jākì kā, before the Halusàs came, the Angass never saw a donkey; when; dǒk mă tǒk bì-nì, dăng mă yāl mět = when they sitil this, (then) they got up and went; dork, in this sense, sometimes becomes ădork, which would have done equally well in the above sentence: sheǔk dok $n$-tī, histor'y; yì dork n-tī, times of old.

dork. . silence, to be silent; mă por drk, they are silent; mănta ă-lăp kăt, ă-dǒk kăs, or ă-dơk bì-fā, don't inswer (him), but just keep silent; dǒk shět, absolute silence.

dǒk dǒk . (a reduplication of dǒk, yesterdiıy) the day before yesterday.

dōm . . to begin, a beginning; ă-dōm chľn-kĕnŭ, begin to do it, lit. begin its doing.

dōm . . to bend down; mă dōm kō mă mär, they are bending lown (to work) to farm; mŭ dōm kā. mŭ chirrăng (for chĭn răng) kwăt è ? if we lo not bend lown, how can we do it?

dōn . . the various kinds of rubber. See lwēt.

dōn or dōn possibly a softened for'm of dǒk, yesterday, dōn formerly; dǒk $n$-tì, or dōn tī, in days of old.

dōn. . . a grass, cut and brought in for hor'ses and cattle.

dǒng . . a drop'; dǒng găk găk, drop by drop ; ăm döng, a drop of witer; a spot; a stain; ă-văng bì dŏng-dă, wash out the st:iln; also useel for' 'meltell,' of metals; ; chělě dǒng (bǐ), a crucible. See lēt.

dồr. . . angere; dồr găm ğhā dŭng, bābā, you have become angry, father (said (lepreciatively). 
dōt or gentlỳ quietly; à-jì pār dōdōt, come quietly dōdōt at night; mă tŭng pì dōdōt, ăn-fwơt kā, they touch things gently, I hear nothing, i.e. they are very quiet.

dŭ . . for mŭ = we, when used through a third person, a sort of oratio olliqua; lí tè dŭ sě mē ?= (a man relating of another', ways) 'he said "what shall we eat?" apparently only used in tales; probably an archaic form not used now, but transmitted in the stories, which are learnt by heart.

dù . . H. sharun duma, a lizard with red longitudinal stripes along the sides.

dù . . a a stink=H. doyi; ăn-chĭ(n)m mē shĭ bù dū dū dē, ă-bě kě nĭ, ă-lǔk pănă, dū dŭng, what shall I do with such a stinking thing? take it and throw it away, it stinks badly.

dük (yil) . the ant-lion, living at the bottom of an inverted conical hole, in sand or loose earth; mĕt mŭ ghür dük yīl, kō mŭ lăb, let's go and pick out the ant-lion to have a look at lim. H. liurrudu.

dŭk. . . a stake; mă jwăl dŭk = they planted stakes.

dŭk. . blunt, of a knife, axe, etc.

dükk. . deceive. See dik, id.

dŭk or all, every, in 'I'hīl, wokkos, and the hill dŭk-dŭk districts.

dük . . to shake, to winnow.

dǔl . . a club, to fight with, or to throw after game; a bludgeon; a stake to which a horse, etc., is tied.

dŭl . . . a goat pen, sheep fold; ă-kẽ dŭl kwă-gyı̆n ghïi-dă = make a pen to put the goats in.

düm . . to finish; to end; jĭ düm=it came, it has passed; said of an impending evil that has 
gone, such as an armerl band seen approaching, but which has passed by elsewhere; ŭ-jī kěsheŭk ŭ-düm à ? lit. hatve you all come, have you finisherl? i.e. Jave you all come, is there no one left behind? ă-düm gurm, lit. you finish men, i.e. your rot, or spoil, things, and, perhaps, "well! you are the limit!' expresses our ' to the utmost,' e.g. düm pün kŭn nyī=lit. lie finished he gave honour to him, i.e. he honomrerl him to the utmost; it can also express om 'too'; I am too ashamel (to go), kēpăng gnăn kă düm (kwăn-mèt).

düm . . to go; ŭ-düm kŭ tǒk sheưk-dă, kĕ chĭng wŭn, be $\breve{\text { u}}-\mathrm{j} \mathbf{i}$, go and talk the matter over', if it is too much for you, come back.

düm or to have a thick growth; kē düm dŭng, the dăm head is well covered with hair; shwē dí dŭng, dăng mār-dă düm dŭng, there is plenty of corn, the farm is well covered.

dŭmāsē . H. ruan darli=a large cylindrical bead (of foreign (lerivation).

-dün . . inside, the middle, midst; dü̆n lěǒk mă yẽ măt $=$ in the fight they captured a woman; -dün lŭ = inside the hut; kă $\cdot$ dün = the midst; kă $\cdot$ dün wŭn = among your.

dūn . to spoil, to vitiate, be spoilt; dün $\mathrm{kŭm}=$ he desecrated the ritual, silcrilege; năm-dă dün = the meat has gone ball; sin ās mă dün= the roots of the tooth are rotten; bi ke dūn = the matter is spoilt, i.e. mudlled. Siee wăm.

dŭng . . very, exce lingly ; rit dŭng = exceelingly good ; often duplicated, rït dŭng dŭng, id. ; many ; mă jī dŭng dŭng, they camme in great numbers $=$ H. dayawa 
dŭngŭl . a swelling, a hump, as of an ox; wăp dŭngŭl =the swelling has swelled; dŭngŭl pŭt shĕuk kĕ gŭrm $k \bar{o}-n$ tūl =a swelling hạs appeared on the man's body like a wen.

dŭntām . last year.

düp. . penis.

dūr . . bunged up, stuffed up; dūr or kwŏm dūr= deaf ; ăchā (a)-bē kwā (for kwăt), ă-dūr pǒ lū mŭn à? be off with you (idiom), why are you blocking up our loor? küt (n) dūr, a virgin ; to block up, fill up; to stammer.

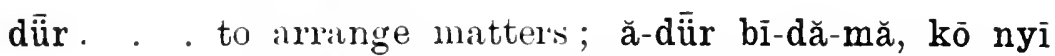
rìt, kō mŭ mĕt, arrange matters, so that it is all right, and we can go.

dūr . . . heart, breast; ḡhā dūr kā dŭng kō mă ăs, you haven't the heart even of a dog.

dīir or dōr anger; ă-dōr gŏ-āmă dŭng, you are very angry with your family.

dūr. . . a proclamation by the king, a prohibition; mă dūr kē kĕ wăt, kō yīl nyī rīt dĭ, a prooclamation on theft has been issued for the benefit of the land; probably connected with dūr, to block up, and so to prevent.

dyōr . a scorpion. Śee yōr.

$\overline{\mathrm{e}}$. . H. $i$, yes; lă ē-kĕnŭ, he took his yes, i.e. he agreed.

$\overline{\mathrm{e}}$ ? . . used in asking questions, placed at the end of a sentence; used generally only when there is already an interrogative word in the sentence, otherwise ā ? is used. Fyĕr sōn răng è? how far off is Fier? where răng=: how? Fyĕr sōn à ? is Fier far off? wē băḿ è ? who seized it? See dē ? and à? 
$\overline{\mathrm{e}}$. . H. tsaba, grains, beads, seerls, etc.; separate; odıl ones; è kün-dă kě bwìr à? lıave the seeds upset?

ěăk or äk the womb, matrix; kēt nŭng tăp äk, the virgin cow has broken her womb, i.e. conceived.

ěăk or āk H. liwrege (jerboa ?), ěăk mă jī (mă) dūn, the kureges have been here and spoilt (our clops).

éăng ol H. prensel, to ransom; to pay; mŭ éang wŭn äng kwăt, dăng mŭ chĭ (n) mě shǐ mā? we have paid you, it's true, but what shall we do with them? i.e. with the things: bought.

èl or èl . H.A. to seize, snatch.

èm . . to cut, carve; èm às, to file the teeth.

ēm or ēp, yauwn; kŭm bĭs yē nyì, kō ēm bě kŭp kā, a 1.: calamity has befallen him, so that his yawn cinnot close again. (So that $=$ viz.)

èp . . to yawn.

ēr . . to scratch; to farm, i.e. to hoe; măntă ă-ēr shī-fā, don't scratch your foot; măt-dà ēr có-kin māl, the woman scratched her sister's foreheal.

ès . . H. gari, flour; ă-dăp ěs shĭ kār, kō ă-chĕt mŭn, tike the flour from the shelf and make 'tuo'; gwǒk ěs, to grind corn ; also $=$ H. yuzuri, provisions for a journey, incluling money, clothes, etc., as well as food itself.

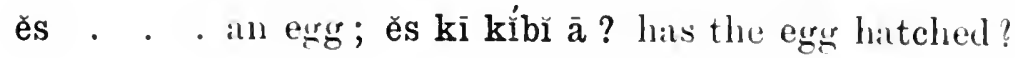

fã . . inseparable poss. pron., 2nd pers. sing., m.; brüng-fā, thy liorse $(\mathfrak{f} .=-f \bar{i})$. See -fănă, -fŭnŭ, andel -fū. 
falp or H. harkarhi, the flat. brown, spotted, horse and fwălp cittle fly.

-fănă . . inseparible poss. pron., lst pers. sing., m. and f. =my ; brüng-fănă, my horse; often contracted to -nā; ăn-fìs bănè-făn-dă (for -fănă-dă), I have scraped the hairs off my leather apron; pŭ-nā, for pŭp-nā = my father.

fărm . . a cold. See fwărm.

fătăt . any kind of cloth in general; măt kĕ kărăng mă (g)yĭn fătăt kā, yĭm găk, the Angass women do not put on cloth, only leaves; fătăt wŭm gŭrm, a shroud. See fwět and tăt.

fĕt . . to sweep up, to clean up by sweeping. See fwăt. fhĭl. . see fĭl, to skin.

fhō or fō to pour out, put aside; ăn-nē mŭn pŏ fhō (kěnı̌), I see the 'tuo' spilling out. See fō. -fī . . inseparable poss. pron., 2nd pers. sing., f.; brüng-fī, thy (f.) hor'se. See -fā.

fi . . to dry up, to place in the sun, to air, to blow; fi fărm, to blow the nose (in the native fashion); ă-fī rīp ă-fō, dry the chaff and pour out; to be dry; shřt (kě) fī, kō wŭs kĕ sě, the grass is dry, so that the fire will catch (eat).

fī shī. H. mafuiru, an insect, which lives in a hole in the ground, and blows or spits on the foot of those stepping over it, causing a blister, which is called shi bŭt bŭt.

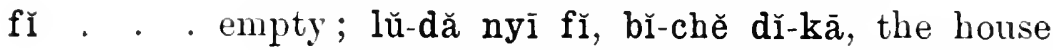
is empty, there is nothing inside; gwŏ-dă fï, a poor man; bŭt fĭ sĕ bì-chĕ kā, the stomach is empty, it has eaten nothing.

fŭl or fhĭl to skin; ă-full shrmm mŭlūt gnăn, skin the leopard for me. 
fĭl . . to boil; ăm fìl, the water boils, or, boiling water'; ăm-dă fīl mŭlk (kă) sār gnăn, the boiling water blistered my hand (lit. blistered to me the hand).

fil . . thin, as a sheet of paper.

fill . . the slough, or cast skin, of a snake; also as verb, to slongh, to cast the skin, to take off (of clothes).

fill măt . a grass of which the pó-bwin, or waist belts, of women are mate.

fìm . . H. alulugal, cotton ; Kărăng-mă mă kwơp fīm pi găk kā, pī găk găk, the Angasss lo not plant cotton all in one place, but here and there; fìm tăt, thread.

fïp . . Whistle, tē fīp, to whistle; ă-tē fīp pār bě jĭgwěl mă lăp, if you whistle at night the spirits will answer (mă dăp d dō-ğhā mă mět kěnŭ, bě ă-tār, if they take up your sound and go off with it, you will go mad).

fip or fwip hair, of the head, of skins, etc.

fir . . to scrape, as of a calabash of porrilge, with the fingers; fir werr, the porrilge scooper, i.e. the forefinger.

fïr . . four ; mă fīr mă sū, they four have fled ; kōfïr mă sū, four have fled; gð̃-fïr, or dă-fïr kèmă $\mathrm{su}=1 \mathrm{I}$. na luulunsu ya gumlu= the fourth laas fled; shī fìr, or shăk fïr, four times.

fīr . . 11. !nenkit, the roan antelope; mă pŏ gāiyā kè fïr, they are hunting a grwenki.

fis . . to scrape ofl the hatir on in skin for tanning; ăn-fĩs băně-făn-dă ('゚or fănă-dă), I have scraped off the hair of my skin (i.e. the one wom hanging down behind); to be bald, to be free of hair; kē kě gwǒ-dă fis kět kět, the man's heal is quite bald. 
fô or fhō . to pour away, or throw away anything not. wanted; to discard, to waste; mŭ chĭn răng nyē (nyĩ ē)? mŭ fo găk găk, what can we do with it? let's just throw it away; ke kwơk kě děn kā, kè kăt bī kě fơ-fō, he does not save up, as soon as he gets any goods, he wastes them.

foglok. . the trough between the ridges of a farm on which corn is grown; also used by some for a sinall stream bed; fŏglợ kè zăl mār, the hollows of the ridges, a small depression.

fŏk or tin; solder; mă kăng shĭ fwork, they joined fwòk with tin, i.e. they soldered; ăm fwork, liquid, or melted, tin.

fork . . to dig, as a farm, or a hole; ŭ-mĕr (= ŭ-mĕt) ŭ-fŏk tūn mŭn, kō mŭ wŭm gwŏ-dă dí, go and dig us a grave, that we may bury the man there ; = ǒk.

fongfŏng . H. lazara, the wet season; reduplicated form of fwăn, rain.

fōp . . the shell, of an egg; also the hard shells or pods of various fruits, such as the măs or dorua tree. See fwōp, ill.

-fū . . inseparable poss. pron., 2 nd pers. pl. m. and f.; brüng-fū, your horse. See -fā.

fŭk . . bellows; mŭ yĕl ghü̆ pī fŭk, we flay goats for bellows; pĩ fŭk shāl, a furnace. See chĕt.

fŭk. , the lar'ge load of salt; mă jī kĕ fŭk kě (n) găng, salt comes from Yergum.

fŭk . . to start out of sleep; to show signs of life when believed to be dead; mŭ nē kè mūt

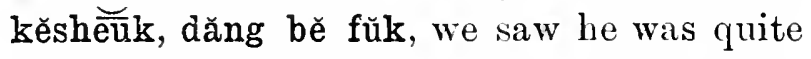
dead, when suddenly he came to life again. fül . . . soil exhausted from cultivation; mār-ãă fǘl, kō rìt shwē kà (or, kō shwē rīt kā), the 
farm is exhausted, so that it is not good for corn (or, so that the corn is not goorl). fŭng . . midst, among, middle; ă-rǐb jělmăt shř fŭng shr fŭng, divide the money among them; a crack in the rocks, such as the aysralu (H.), or coneys, follow, = fŭng chŏm: mŭ wŭl fŭng-ní kō mŭ kë jwăl-nĭ dŕ, let's follow this crack ('chimney'), to elimb this rock; to thread one's way, among a mass of liuts, ete.; fŭng (tōm), a vein (of llood); probably same as the following.

füng . an opening, a window; a reatson, callse; ănrōt lěǒk kā, mě ăn-kăt fŭng lěǒk dăng, I don't want to fight, unless I find an opening, or caluse; pro fung, a back door of a house made in the zè or wall joining two huts; also called fŭng kwip.

-fŭnŭ . . inseparable poss, pron., lst per's. sing. pl. m. and f.; brüng-fŭnŭ =our horse; sometimes contracted to -nŭ. See -fā.

füp . . . a sledge hammer, of blacksmiths.

füp. . the hollow of the iron hear of a spear, into which the shaft enter's.

füp . . a membrane, thin skin, such as the bladder. see lir.

für . . an open space in front of a house, generitlly surrounded by a stone wall; the scene of dances, ceremonies, etc.; ne für, or teūng furr, the $H$. rhedlia tree, as this is nearly always selected for its shade, adjoining which is built the wall.

für-bŭt . H. lilcibi-n chillili, the lower part of the silles of the body.

fŭr-bŭt . a subject (of a kingr); gworm-Bēt mă für-bŭt ker Lăn-kŭk, the people of Bet are the suljects of Lankuk; go-fürbŭt, a subject; a 
qualtel of a town; fŭr-bŭt-fŭnŭ shř-kēe our 'puarter is separate.

fŭrm . . the knee; dē (yǐs) por fŭrm, the knee-cap hone; mwĕn shĭ fŭrm, to proceed along on the knees.

fŭt . . a mosquito; fŭt ăt gnăn, a mosquito bit me. fŭt . . a leep hole.

fŭt . . H.A. the stocks (for the feet) = P.A. tōrī (the baolial tree); mă lěb ny̆ fŭt, he was put in the stocks.

fŭt . . to vomit; ăn-nē ghhā bě rīt gnăn kā, kwăn-fŭt bì dŭ, the sight of you is not pleasant, it makes me vomit; in H.A. this may be expressed, ăn-nē ğhā shăng fŭt kĕ bī bŭt gnăn; ăn-sĕ bī büs kwăn-fŭt dŭ, I ate something nasty, so that I vomited.

füt or a sigh.

nyǒk fūt

fwălm . - bity colour, of a horse, goat, etc.; also, not exactly red, e.f. a man whose skin has peeled off; gwǒ-dă yāl kĕ lě, kỏ sheūk fwălm, the man has become convalescent, his body is redlish (i.e. lighter than usual).

fwălp . . the big flat hor'se fly; fwălp-mă mă ăt brüng, the flies bite the horse; also fălp, q.v.

fwălp . . to strip, peel ; fwălp dărm yōm-dă mŭn, kŭm (=kō mŭ) běl wŭs, strip some tree bark for' us to light a fire; fwălp zŭm-kĕnĭ, strip off its skin (back); also fwŏlp.

fwălp . . in fwălp gwŏng. See gwŏng.

fwăn . a slave; nyī fwăn-fănă dō nyī, he is $m y$ slave; mă fwăn-fănă-mă dō mă, they are my slaves; Kărăng-mă kĕ fwăn kā, mă năng tě teūng dē găk, the Angass do not have slaves, (nnch as they have) they call them 'sprouts' only; fwăn is the term for 
one who is a slave in another race, e.g. the llausas ; slavery proper is unknown, though the Angass keep people in pawn for a lebt, etc.; fwăn kŭk, mă lǒk mă sìt ğhā, you cursed slave, in a little while you will be sold (abuse).

fwăn . . rain ; fwăn-dă pŏ tē, lain is falling ; fwăn chŭk-ăn, the rain beat me; i.e. I was caught in the rain ; kō fwăn nyř tē ānhhā! kě măng, kō mŭ wè dō dā? how the rain is falling ! when will it stop, that we may go home? fwăn yāl, the rain has risen (saicl of a storm); fwăn tōn, black, gathering, storm (tōn = heavy).

fwărm. a cold in the head; also mucus of the nose; sometimes fărm.

fwărm . . the initial stages of smallpox; when the eruptive pustules of the disease appear, it is called pǒ-t $\breve{\text { eung }}$; until these appear a victim will call his indispositión fwarm, or a cold, to try and hide the dread reality.

fwăt . ashes; ă-fèt fwăt, sweep up the ashes; wŭsnĭ lě fwăt dŭng, this fire makes a lot of ashes.

fwăt . to scratch the ground, as fowls; perhaps the same as fĕt, to sweep, clean up by sweeping. fwèp . . fat, stout; of men, animals, trees, etc.

fwèp . a smell, a stink; also a pleasant smell; to smell, sniff ; kărbăk pǒ shwē fwēp kĕ gŭrm, the hyena is snifting the scent of a man; ăs-dă fwŏt fwēp kĕ b̆́-chĕ, the dog scents something.

fwèt . a particle; ă-yāl lēlē, fwēt ! get up quickly, will you !

fwèt . H.A. = P.A. fătăt, cloth; also, the strips of cloth known as fari (H.). 
fwin . to tie round tight; to gripe; bŭt fwin, the belly gripes; also, the rumbling of the belly; a stomach ache.

fwìn . . (1uarlel; gŏ-fwīn, an enemy; dōn mŭn fwin kě mă, yesterday we cuarrelled with them.

fwip . . see fīp.

fwök . tin. See fök.

fwǒlǒk . H.A. for P.A. fŭfwǒk = the lungs; dür-nă mă fŭfwǒk mwă lěngăn kĕsheük, my heart aml lungs are all paining une; ăn-fwŏt fŭfwŏkfà, 1 hear or feel (or', see the motion of) your lungs (said to a sick man by another, after either noticing the rise and fall of the stomach, or by placing his ear to his breast; a good sign).

fwŏlp . . to peel. See fwălp.

fwōp . . shell of eggs, snails, multipedes, etc., but not the bark of trees, except the stalks of guinea corn, etc., which = fwōp yăng; also föp, $q \cdot v$.

fwŏr . . river, stream; děl fworr, to cross a river.

fwŏt . hear, understand, feel; ăn-fwǒt shĕūk-tǒk-fä, I hear what you say; ăn-fwǒt düm, or ăn-fwŏt kĕt kĕt, I understand perfectly ; ăn-fwŏt lè-kĕnı̆, I feel pain (lit. its pain); ăn-fwŏt ăn-sĕm kā, lit. I have heard, I have not slept=since I have heard (the bad news) I have not slept; ăn-fwŏt shăngkĕnı̆ = I feel pleasure at it.

fwŏt kwŏm news, information; dǒk mūt (băng), ănor kwŏm fwŏt kwŏm-kĕnĭ, he died some time ago, fwǒt

I got news of it; kwŏm fwŏt pwì, fresh news.

fyāl . . to burst from ripeness, or from sufficient cooking; bǒk fyāl, kĕ lŏk nŭng, the bean has burst, it will soon ripen. 
fyāl . to saty a thing, and when the discussion is over, to say the opposite.

fyăng . . to bore (of witcheraft) the heall (those who are wizards have small holes through the skull, only recognised, of course, after death); to aceuse one of having his head hored by reason of being possessed of witchcraft ; ŭ-fyăng kē gnăn, ākŭk, ăn-măn bíchĕ kā, lit. you bore my hearl, i.e. you aceuse me of witchcraft, on no grounds, I know nothing.

fyük . g grasss, bushland. Cff. H. joliko or fuliko.

gădjētt. . an old man; ancestor; gădjĕt kŭn dŭng, kě mwĕn bě mwěn ká, the old man is very tottering (old), he cannot go and come; gădjĕt-fŭnŭ mă wē-n kwīp, mă jī mă lē - mŭn bĕ-nĭ, our ancestors came from Kiwip, they came and begot us here.

găgăt . H.A. for dŭntām, last year.

gāiya . . to do a thing in a crowd, e.g. hunting; borrowed from the Hausa gayya.

găk. . . the numeral, one; găk liss, or, găk lrlǐs, exactly one; kō-găk = subst., one; kō-găk gū, one fell; nyi găk =he one, i.e. he alone; only, merely; ăn-rōt năm găk, I only like meat; găk găk, one at a time.

gāk. . H. deillei, a long grass on the banks of streams.

gāl . . . see under gwǒk, a locust.

gāl or yăng sulgar cane; shăng kō gãl, it is as sweet as gàl sugar cane.

găm . to show, explain, teach; găm chĭn-kěñ gnăn, lit. he showed its doing to me, i.e. he showed me how to do it; găm děl mŭn (idiom), he 
has shown our anthority, i.e. our superiority, or, the way' we do things, i.e. he has 'given us awily.'

găm . . to fill, complete ( f. H. !/amma); lŭ găm kĕ shwē, the room is full of corn; ă-găm lèlè = H. Lia rhililia sauri, you do (talk) fast; ă-găm pǒ kě shǐt-chĭn lỉī, you do work slowly; mă găm pǒ-kěnĭ, they are complete or completel, e.\% as of a certain number of labourers; dălơng găm kě păs, the quiver is full of arrows; ă-găm kō nyì găm, measure it out till it's full.

găm . . to kick (of animals); pŭs shĩ găm gnăn, lit. he shot his foot and kicked me.

găm . . to measure.

gămsūn . H. juda or jibcla, the civet cat. găng . unripe, raw (but not of meat, which is min), of firuit, vegetables; kŭdĭ-ngăng, kĕ nŭng $k \bar{a}$, it is still umripe, it has not yet ripened; uncooked, of fruit, etc.

găng . H. Kallia, a species of palm.

găng . . a Yergum (S.E. neighbour's of the Angass); gŭrm kĕ tŭ gŭrm, bě sū mět găng, bĕ bār, if a man killed another, and fled to the Yergum, he escaped (punishment).

găngŏr . . see kăngŏr.

găntăng . H. zaure, a porch, a hut at the entrance of a house; găntăng lĕm, the house of Lem, a ceremony in which women may not take part; găntăng ār, a porch with a door into it, and one opposite to pass out through the hut; găntăng wărn, a big, more or less public, polch; mŭ tŏng găntăng wărn mŭ tŏk gōldă, let's sit in the big porch and try the case. gāp. . tongss; gāp kwŏlm mă dăp shāl dün wŭs, tongs pick the iron out of the fire. 
găp . . H.A. to cut=P.A. chěn.

gār. . . an edge, such as where two sides of a rectangular box meet; a projection, knob; rising ground; a hillock; II. grergara; teūng kě-n-gār kā, a tree with no frojections or branches to catch hold of in climbing, as some pratms.

gārū . used especially for Bauchi ; a Hausia word = a walled town.

găs . . to scoop out; to ladle out, with a spoon, or it small calabash, as in eating out of a large pot.

găshī . a spear'; mwălm lŏk găshī, a shooting star.

găt. . H. kün, conveys a frequentative meinning; găt mă chǐn ānhā, they are in the habit of doing so.

găt. . a sort of exclamatory emphatic particle; bì găt ādā wēr mŭn kět kět, good gracious! this sort of thing is absolutely forbidden to us; măt găt ănhā, what an extraordinary woman! sheūk-chĭn găt ānihā-nĭ chōr gnăn kă chör-chör, this dreiulful sort of disposition innoys me exceedingly.

găzăk . H. tsekki, roughly ground flour; also, flour is mixed with water, and, after the water is drunk off", a residue of wet flour (găzăk) remains, which is then eaten.

gèl . . a large species of praying mantis. See ăs kĕ worng.

gèm . a lam; gèm ki kìr, a ram kept in the house and fattened up, and pettecl till it is killed.

gèr . . . swagger'; yěm-dă gēr dŭng, the boy is swaggering insufferably; to show off one's good points (quite the correct thing to (lo); gwordă gwơr shěuk-kěnĭ kō kě mwěn kě gēr, the man has put on ormaments so that he 
maly walk about and show himself off; gwok às-kěnì tě gwơ-dă gēr, she has filerl her teeth in order to be consillered smant.

gèr. . a solt of white cactus with long thorns, its milky juice is injurious to the eyes; H. tinia.

gërmŭn . race, lineage, perligree $=1 \Gamma$. ania; traced through the mother; lineage through the father is jëb nün; any casualty to the family, such as selling as a slave, death, birth, etc., is at once reported to the heal of the family, i.e. to the man from which the mother of the family in which the casualty occurred is descended; the gèrmun of a married man of Kabir may therefore be in Pankshin.

ğhăl . a swelling, an abscess, generally used rerluplicateıl; bī ğhäl ğhăl, an abscess; bī ḡhäl ghăl kăt-ăn găk, ăn-măn fŭng-kěni kā; an abscess has got hold of me, I don't know the cause of it; a blister, such as is caused by a first working with an unaccustomed tool; skin eruptions, such as pimples, etc.; also ğhăl and gwăl.

ḡhílílē . . see gíliǹlē.

ḡhǐr or a thorn; tē nün ğhĭr kō gyŏng ny̆̌, he fell ghur into the thorns and got pricked.

ghirrr . to tell ererything, from the begimning to the end, as in a court case; à-ḡhirr mă kō mă fwot, narrate to them the whole business, so that they may know, or, understand.

ghit . . the pagan armlet of iron, worn either on the wiist or above the elbow; ğhr̆t gwŏn-dă lē sār gnăn dŭng, the armlet hurts my upper arm very much; pronounced very short, almost, ght. 
ghrt bèl the iron anklets which, on stamping on the ground in time with the drums during dances, give forth a sound akin to thint of cymbals.

ghk or

ghǚk

a stone, a rock, etc., small enough to hurl; rip kè ghhk, lit. a girl with a stone, i.e. a 'thunder stone,' supposed to bring luck; applied to a girl who is not good-looking, but nevertheless is desirahle, perhaps corresponds to our ' chinrming.'

ğhŭ . . . = to urinate. See gĭzn.

ghüi. . a goat; pronounced very short, almost ğh.

ghhül . . to be satisfied; shwe ké ghül, to drink to satis-

faction; ăn-kăt bŭ-sĕ ăn-ğhül, I have grot food and eaten $\mathrm{my}$ fill=H. loshi; sheuk tơk-fā găk (nỹ), ḡhǚl bŭt gnăn dŭng, your word is one, I am quite satisfied (with it).

ghür . . to pick up; mă pŏ ghür kě shwē, they are picking up corn; ü-ğhür, ŭ-ğhür, pick up your tools (sail to labourers; when said fast, sounds more like ŭ-wŭr, ŭ-wŭr); to pick up -of many things such as stones, or the many articles comprising a load ( $\mathrm{daxp}=$ to pick up one thing only, such as a box); also to pillage, loot, in war.

ğhŭr . see ghhrr, a thorn.

ghŭr . . to lay back the ears, of a horse; brüng ghŭr kwom, the horse lay's back its ear's.

ghürrm. . H. waki, beans; string made of the plint's fibres $=$ pŭs ğhürm.

gì or gyi . to seek, look for ; gnăn pŏ gī-kění dăng chr̄̄gan; l am looking for it, but it has eluded ine; ă-tăp! kè gi lä̉k, look out! he is seeking to fight, said of a vicious horse.

ğgyăk. . see gyăk. 
gílilēe . shout, war shout; the clamour raised by women when they heal Wŏng is passing, or coming.

gĭn. . helow; gwŏ-n gin, the people below; y̆l-ngin, the country below, said by the people of the hills of those in the plains; ăn-kăt nyì gĭn kĕ jwăl, I found it below a rock, i.e. in a cave or at the foot; sometimes almost gyin.

gir . . to close up; jam together, so as to leave no aperture; shăng gĭr gĭr, a children's game.

gĭrp . . to cover, protect. S'e kĭrp.

gnā. . . a big edible frog = H. Lncreutugi, or, ragon allah.

gnắn . . I, me, to or for me. The ' $g$ ' sound is often omitted in the nominative where euphony is desired, it is only slightly sounded in any case. In the objective and clative cases 'gnăn' is often sounded as ăn, the 'gn'

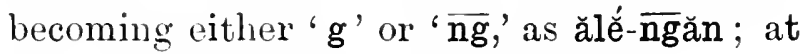
times, again, the final ' $\dot{n}$ ' is dropped.

gnèt . perhaps the same as nèt=red; a particle; ă-jī gnēt, come quickly ; nyĭ lì gnēt, he said so himself; āng èt, for ān (short for ānhā) gnèt = all right! that's so ; ă-măn gnēt à ? are you sure? ăn-măn gnēt, I am quite sure. gŏ . . a man ; in composition it often becomes gwŏ, as in gwŏ-dă, the man; gwŏ-n̆̆, this man. It is seldom used by itself for 'man,' but very frequently in composition. Thus, gǒmă, for. 'men,' is never used; but gwŏ-dămă is correct; gŏ, however, is used in the singular for a youth or boy; e.g. ăn-lăp gŏ kō mĕt lēlē bĕ kō jì dĭ, I have sent a boy to go and come quickly; also used like the Hausa clengi, or family; gwŏ-nā =my 
family; it also corresponds to the Hansa mai, the noun agent; g $\delta$-mĕt $=$ mai-ta!jia, a traveller; gŏ-lăb, a messenger'; gŏ-kŭn, lit. a great man, i.e. a chief, or a hear man, an elder'; gwö-löng, lit. mai-dulia = owner, possessol of riches, and king; sometimes gõ, for ellphony ; gŏ-sě-gŭrm, a cinnibal ; dǒk-ntī gwơm Păng kĕ pŭs gŭrm bě sě, in the old diays if a man of Pankshin shot a man he ate him; gwó-măn, one who knows, or can, i.e. skilful; gwó-măn păs, ‘ skilful bownaıı; gwŏ-măn yük lŭ tābā, a skilful tobacco pipe maker.

gơ-kē ol a taclpole; gwǒ-kē bār lěmwăt, the tadlole gwŏ-kē becomes a frog; a man with a big hearl; the big or headman of a party; nyī dō gwo - kē-kĕmă, he is their chief ; also= representative $=$ H. ualili .

gōl . . justice, juclgment, a law trial; mă tŏk gōl kĕ gwŏ-dūr kā, one does not tl'y a dumb man; Nĕn chĭn kō gōl-fănă rīt gnău, Gorl grianinterl thit the case turnel out well for ne; göl kĕ děn gō rōt băng, justice connes lown on even the man it loves.

gơng . . H.A. for', to look.

gŏng bì . H.A. for, pǒkīn pyē =a hor'se with a hlaze, or white streak down the front of its face.

gor . . a plant used as a flavouring in cookery ; at species of (H.) yalua = II. !numu:

gor . . a lumatic, idiot.

gơr . . see gwăr.

gơrng . . crookel, bent; ār-nı̆ görng, the roal is crookerl, ol very wintlingr; gwơ-dă gŏrng shëuk-tǒkdă =the man has mudelled up, or falsified, the matter'; băk ngworng a crooked line; to bend; mă gorng, bě tăp, if it is bent, it 
will br’eık ; dār kām kām, kō gơrng bě gơrng kā, it is stiff, aull unbenclable.

gōt or a cave; shĕ gwöt dwellers, i.e. the hill people; also, a hole such as a snake's; any hole which is lived in.

gŭ . . . a cactuss $=$ H. liendara, very thorny ; formidable fences are made of it; also an arrow poison (not very virulent) by the Suras at Vodni.

gü . . to fall, from no visible cause, when one is walking or rumning; see kēl (to fall from a height =tē); gnăn pǒ mwĕn kō ăn-gŭ d̆̀, as I was walking along I fell; brüng kām kā, ă-tŏng kě kē kě mět gŭ, the horse is not strong, you are always expecting it to be on the point of falling.

gŭk. . . curled up, bent.

gūl . . H. burtu, a pelicin.

gŭlit . . the grizzard, of a bird.

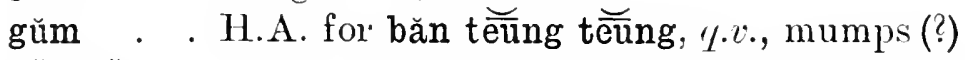

gümdük , dark, dusky, as a dense thicket, but not absolutely pitch dark. See rāp, and kwī.

gŭm gŭm . round, circular ; lŭ kě kărăng-mă gŭm gŭm,

lŭ kě tŭrāwā pām pām, the Angass houses are round, those of the English are rectangular (flat surfaced); mă gŭm gŭm, they are round (said of some marbles shown to them).

gün. . that portion of the inside of the cheek that covers the teeth from the back to the corner of the mouth, i.e. the place where one puts a quid of tobacco, etc.; to chew or suck; ă-lăp tābā-n gün, put the tobacco in your cheek; ăn-lăp lüs tābā kā, it's my tongue, not tobacco; said by a man when 
another thinks he has some tobaceo in his cheek and asks for some; also the cheek itself ; băk gün, to cut a tribal mark.

gŭn. . dirty ; ăm gŭn, dirty water; ès gŭn, dirty flour.

gŭng . . H. gamiji, a tree griving a species of rubber ; it has a reddish juice; ăm-kěnr nēt, its sap is red ; kăsběn (ăm) gŭng, copper.

gŭr. . . to collect in great numbers, a great assembly or gathering; mă dār gŭr ·bě-n̆́, they have collected here in large numbers.

gŭrm . . a man, at human being ; gŏ-gŭrm, a very fine fellow, a 'brave,' a trier.

gurnà . applied by the P.A. to themselves arrogating superiority as being a class higher than the Hill Angass; and so comes to mean niceties, etc., of the linguage, the conrect language, idioms, etiquette: (probably of foreign derivation).

gŭrng . . = gorng, crooked ; to bend, etc.

güit. . the small (land?) tortoise. See kŭr.

gŭtŭng see kŭtŭng.

güzn . . urine; ğhŭ gŭzn, he has urinated; gứzn lě nyi, he has gonorrhoea.

gúzzŭk . H. iboru, a ggrain food; sãr gúzŭk, the small (handful) bundles of iboru tied together, preparatory to making the final big load to carry liome; păng gŭzŭk, see under păng.

gŭzŭm . . a rat, a moise; gŭzŭm lŭ wēr mŭ tŭ kā, mŭ kăt mă pŭtōl dăng mŭ tŭ, we do not kill rats in the sacred house, but if we find them elsewhere (ontside), we kill them.

gwăb or to twist, as string round the finger.

gwăp

gwăbzăng. H. maklia, the iron thumb grand used in shooting arrows with a bow; also all the 
curious little articles used as adormments, lunug on to the neck, shoulders, arms, legs, waist, etc., at dances ind festivals, such as teeth of leopards and other animals slain, bits of tin, old cartridge cisses, feather's, claws, and so on. See gwăb, and zăng.

gwăk or a trap; ăn-bwŏt gwăk, yē bri-chĕ kā, I set a gwǒk trap, (but) it has canght nothing. gwăk . . to grind (cornn); ā-yăk shwē ă-gwăk lēlēn, take some corn and glind it fine; ă-gwăk ěs kō mŭ shwē kă ār, grind corn for uss to lrink on the road.

gwăk . . the Jarawa, the N.E. neighbours of the Angass. gwāl . . a stick covered with red earth, fixed in far.ms in Kabir only, to keep people, especially if diseased, off the farm;. if desecrated, it punishes by skin eruptions, which can only be alleviated by the sacrifice of a goat; the skin eruption itself ; gō kĕ shwār gwāl, bě yë nyī, if a man ridicules the stick, it will punish (catch) him.

gwāl . . rain cloucls; pī gwāl, rain is threatening. gwāl . testicles.

gwāl . . H. bururu, flour mixed with boiling water, and made into small balls; small lumps or balls; pimples, or any skin eruption such as sinallpox; sometimes gwăl. See ghắl.

gwām . . the black on the inside of roofs, due to fires and smoke; soot.

gwā-(mă) . the Hausas; tracler's; găng bār n-gwā, a Yergum man has become a trader; civilised foreigners in general, e.y. Bornuese.

gwăn . . to strain over heavy work, as in lifting a load; the sound marle in straining; ăn-tŭs ğhk kwăn-gwăn, I strained hard to push the stone. 
gwăng. . a large thorn tree, which grows near water; H. liama lifidi.

gwăng. . to prevent; gōl gwăng wăt wŭn kă yill, the law forbids you stealing in this country; to hinder, wiud off ; măt yinn gwăng, $\bar{o} \bar{o} \bar{o}$, the woman with the ('olive' or peace) branch prevents you (said by a woman who steps in with a branch between two fighting parties, who then leave off their fight).

gwăngălăng the millipede.

gwăng the Harmattan haze; H. hazo; gwăng gwăng gwăng dūr pī, kō mŭ lăp pị, mŭ nē kā, the haze has shrouded everything, so that if we look anywhere, we can't see.

gwăp or to twist, as string round the finger.

gwăb

gwăr or gor the H. baude tree.

gwār . . 2nd pers. sing. m., of a sort of oratio ouliqua. It is only used when a person is repeating inother's words; $e . g$. 'go' $=$ ă-mèt, but in a narration a man will say 'goffwăn tě gwăr mět,' 'Gof wan then said to him, go'; also used to an interpreter to signify 'tell lim'-lit.'(tell) you'; Něn yı̌t gwār, say to him 'God lengthen your' days'; dō(n) gwār dŭng, a salutation $=H$. samu $d a$ wohalla, say to him "your trouble is plenty'; this salutation is also used at the end of interviews =' many thanks, you have taken a lot of trouble.' See dŭ.

gwār . round, spiral patterns; gwār kě lŭ, the spiral and circular patterns made on the mud walls of a house.

gwās . The wild pig (a domesticated pig is unknown); mă kăt às kĕ-n gwās, bè mă tĕ tìtắn, when 
"I boar's tusk is foumd one beats the titan (a musical instrument) with it; i.e. the tusk is used as a hammer or striker.

gwăs. The swelling of the face due to toothache. Sce bŭn.

gwēr . . to grroan; mŭ jī, mŭ kăt nyī pŏ gwēr, kě mūt kà, we cane, and found him groaning, he was not dead.

gwìm . II. gaya = flour mixerl with boiling water. S'ee mŭn.

gwìr . ampaired, the odl one over, in counting by twos; a bachelor, spinster. Cf. H. guroro.

gwó-bĕl- H. mai-fura-uuta, i.e. one who blows up a fire, wŭs used for a regent, or for one left in charge, as of a house, in the owner's absence; gwŏběl-wŭs gǒ pŏ tŏng pŏ pŏ, the caretaker sits at the door; gwŏlŏng mĕt, nyì kō (or dō) gwŏ-bĕl-wŭs, the king is away, this is the regent. See gŏ.

gwŏ-dăp- 7it. one who takes up fire (and gives it to the wurs king for his pipe); one who attends to the wants of the king, a chamberlain-the one who at all times has access to the king= H. turailiz dalika. See gŏ.

gwŏ-jō. . H.A. jū (or rather, the latter is used for the female only), a lizard; ă-dār, kwăn-tū gwŏ-jō ghā, wait, I'll kill a lizard for you (said to youngster's to pacify them). See jō.

gwork . . the locust = H. fara; ă-mwĕn kwă-yē(n) gwǒk kwă-sĕ d(r), go about and catch locusts to eat; various kinds are :- -kŭm kōll, tēr kĕ nyĭn, fīp năng gŭl, bwāı pē, kălè́t năm tōrī, kwākĕrếs, fīp nyīr, gwǒk bāwō, gwǒk mūr, gwŏk kě ká; gwǒk măt kē, gwŏk kŭs nŭng, gwŏk kwār ğhk, gwǒk kĕ wŏng, gwŏk 
kămwŭn, gẳl; all except, măt kē, fīp nyīr, and năm tōrī are eitten.

gwork . a trap ; bwơt gwork, to lay a trap; mă bwort gwơk pī năm shǐt, mă bwơt pī gŭrm kā, one layss a trap for same, not for men. See gwăk.

gwơk . . olıl, useless, spoilt; ă-yr̆t gwǒk-kĕnĭ, ă-dăp kō rì-rit, leave the old one, take the grool one; gwǒk dè, a broken calabash; gwǒk (kè) sheuk tork, a matter (speech) of very old bygone times; gwők năm = useless meat, such as a stinking carcise, etc.

gwǒk . to r'ub hard, polish; grinul corn; also gwăk, to rub down a horse; gwǒk às, to file the teeth.

gwǒ-kē see gŏ-kē.

gwǒk kě a species of locust.

wŏng gwơ-lă-

măt

a bridegroom, lit. one who takes, or seizes, a woman; gwơ-dă lă măt, mă pŏ lě dằndằn kě mānzăp, the man has married (seized) his wife, they are playing music for the bride.

gwor-lăp- lit. the one who takes up the word, i.e. the sheuk king's spokesman; the king rarely speaks himself, except in difficult cases where it is his duty to give a final decision, probably so as not to lay himself open to insult or recrimination.

gworm . . in Lankan and Sura; a club, a bludgeon (?).

gwom . . in Tabulun 'labshin =H. l:oshi, to be satisfied with in meal.

gwom . . name for 'king,' in Bukuru and IIill Jarawa (?).

gworm . . to neet = H. yammu.

gwơ-mì. relationship; mŭn gwor-mì kă, we are not related. 
gwö-mǔs . (lit. a man, male) a man, but especially a brave man, a Wurı́iol; gwŏ-mǐs dĕl kĕ gŭrm-mă kěsheũk, a lirave man surpasses all other's; a male; gwö-mís nŭng, a bull.

gwŏn "snake in greneral; gwöri ăt, the snake bites; gwŏn் mălp=Il. gumshelia, non-poisonous, but spits in its adversary's eye; its bite causes a festering sore necessitating, generally, amputation of the foot, finger, etc., bitten; kwŏl, m., gwŏn pyē, f.=H. livalia; kăjǘk = liasisa liassa, a small very poisonous snake; kūn, a fat black and white snake= H. ganuo, found and allowed in rumbus, if it dies, a boy of the house lies too; myirm =the python; gwŏk tē =H. liazan vua, a pugnacious poisonous water snake; nāng= the hooded snake, cobra; sēn, a very pretty non-poisonous snake generally found close to watel; păng $=$ H. liasa; frll, the slough or cast skin ; gwŏn fŭl shĕuk-kĕnĭ, the snake has cast its.skin (lit., its body); gwŏn(g) yüm $=\mathrm{H}$. dainyen chiava; gwŏn $(\mathrm{g})$ mĕlp= H. 7iumurchi; gwŏn dŏng bět = H. liululua : gwŏ̀ lŭ kĕ tŭ gŭrm kā, proverb-a snake's hole does not kill a man; găt kĕ yĭn à (ā for kā) gwŏng bĭs, kĕ sĕ gŭrm, tēr kŭdĭ kā, bĕ bār kā, there is no remedy whatever, a deadly snake, if it bites a man and he does not get a sleep he will not recover.

gwor or the upper arm, including the shoulder; fwălp gwŏng gwŏng, the shoulders proper.

gwŏn . H. yaga, the stage in farming when all the dead or dry leares are removed.

gwong. . used, not very frequently, in the same sense as dhĭr ; ă-chĭn gwŏng-nă (or dhĭr-nă), do it for me. 
gwonng . see gworn.

gwŏngworn the Adam's apple; gworngworn wē prochork, dăng turm bŭt, the Adam's apple rises to the throat and then descends again ; gworngworn nyork kĕ gŭrm, the Adlam's apple is the life of man.

gwontūr t the male generic name for boys of Dawaki; f. chălìm. See sūwã.

gworr . . to ornament, decorate.

gwŏs . H. gardagi, a thorny tree on banks of rivers. gwōt . see gōt.

gwǒ-tǒk a judge; gwǒ-tŏk-gōl ny̆ tŏk mŭn nyĭ rīt, gōl the juulge has spoken to us soundly, i.e. to our' satisfaction.

gwǒ-yin . see yin.

gyăk or a trufi of Wokkos, consisting of a small pot; grgyăk those desecrating it are risited by a host of invisible diminutive people, who annoy their rictim in various trivial ways, such as making curious little nóises, pinching, and so on. They are occasionally to be seen, but if a woman sees them she dies; the sacrifice of a goat is necessary to appense them, and get them to go away. These beings (gyăk) are the special guardians of the 'itiri' and 'mäss' trees, and the taking of the fruit by any one but the owner is visited by them on the thief; giggăk appears to be a contractel form of the reduplicated gyăk gyăk.

gyăng . . to pierce, to bore; sōn kě nŭng gyăng-ăn, the cow's horn sored me; sometimes gyơng.

gyēr or a irumlu (H.), or store house; nü̉n wŏk mŭn yèr kě gyēr kěsheǔk, in our houses each person has his own store house; gyēr yil, or gyèr 
long, the oflicial store house, or treasury, of the tribe.

gyerm. The late evening, aftel the last meal, and before people go to sleep, when everyone is together talking, smoking, telling stories, etc.; the gossip itself of the evening; mŭ ghüul kā, mŭ tŏng gyěrm kā, if we have not had a satisfactory meal, we do not sit telling stories, or, gossiping.

gyì . . to become; gyì bār, he has become mad; gyì măt, he has become a woman, i.e. he cannot go and sacrifice, etc., just like a woman, of no account.

gyı̌l . . smoke. See yĭl.

gyin . to tie, of animals; and also of the leather apron or bante (H.), and of women's leaves; mă gyĭn shīm, nyī dō bănně, one ties the skin, i.e. the lante; to shut up animals for the night; măt kĕ kăbwīr mă gyĭn fătăt kā, yĭm găk, the Kabwil' women don't wear cloth, only leaves.

gyin . . small, little, fine, used not of boys, etc., but chiefly of crops, grass, etc.; often reduplicated, gyĭn gyĭn = H. lianliane.

gyip . the cutting of the harvest, of all tall crops, e.g. guinea corn, gero, etc., see lí; mă lŏk gyı̆p, they are close to harvest time, i.e. the harvest is near'; mŭ gyǐp shwē düm dăng kõ mŭ săl mŏs-lūn, let's finish the harvest first, so as to brew the drink for the harvest festival.

gyīs . . sand; gwā-mă ghürr gyīs mă lě kĕ măsălāchĭ, the Hausas take sand and spread it in their mosques.

gyít . . bitter of flavouring, also of temper'; gwǒ-dă gylt dŭng, this man is bad tempered. 
gyit . . intoxicating, full flavoured, of beer; mors gyit dŭng, kō tŭ dr, the beer is very intoxicating, so that it has overcome him; pi gyit-kèni kō tŭ dí, on account of his, or through his, intoxication, he killed him.

gyŏng . . to pierce; bī gyǒngăn pornǘm, ă-sĭt gnăn dăng, mè ? something has pierced my gums, pull it out for me, what is it? fwip mwoor, a splinter' (hair) of 'gero.' See gyang.

gyơng . . to throw; mă pŏ gyŏng-fünū shĭ ğhk, they are throwing stones at us.

hāi . . no ! a decisive negative; hāa ! ăn-tā, certainly not, I refuse.

jăl . . to belch; to chew the cud.

jăl . . acid, sour'; shăng kā, jǐ-jăl, it is not pleasant, it has become sour.

jălăm . . the rama (H.), from the fibres of which string is made.

jă lăng . sometimes used for jĭ ă-lăng, come and squat, i.e. in obeisance (H. Fia tsuguna).

jălmăt. . currency; in old days applied only to cowries, but now to metal coinage as well.

jălmăt. The breaking, or cutting, of the skin on the sole of the foot, at the base joints of the toes.

jălōm . H. sha:uma, the large jellowish transparent ant, infesting sweet articles, as honey.

jăm. . the gall, of the intestines.

jăm or pó- the chin.

jām

jăm. . an expert dancer. In in grounp of dancers, the girls and women pick out the best (either 
of the men or women dancers), and give him or her a present, e.!. a new calabash, a head of 'massara' corn, etc., which is then hung over the shoulder for all to see, for the rest of the day or occasion.

jăm. . . a species of Indian corn, brilliantly red, and of which ornaments are made.

jān or nēt yellow.

jān

jān or a large, long-necked bird, supposed to kill djān snakes, pulling them ont of their holes $=$ H. zalbe (?).

jăn . . twins; also used of the boy of twins, if the other is a grirl, who is then called jănă; a boy and a girl, twins, are also called jănlŏng, H. masu-sarauta, lit. propertied twins; jăn-mă, also $=$ twins. The first-born of twins, again, is always jăn, or, if a girl, jănă, the second is called dă-kwŏm, or, if a girl, nă-kwŏm; triplets (only one case on recordl)=jăn-kwān. Twins are hailed with joy, but not among the Suras, who, short of actual murder, do their utmost that one of the two may die; mă rĭb br wŭn, bĕ mă pün wŭn găk găk kō jăn, the goods were divided between you, and you were given shares exactly alike, like twins.

jăng . . a bow; mă mwĕn kĕshĕuk kĕ jăng sār, they always go about with a bow in their hands.

jāp . . . see djāp.

jătŭr . a flea.

jĕb. . see jĕp.

jělăng . . rust, l'usty.

jĕln. . H. zanzairo, the big black and yellow wasp or hornet(?) that makes a mud nest in houses. 
jĕp or jĕb . in Sura and Thal =a boy, or child = Angass yěm, but in the latter langruage, jëb-mă is used for the plural, and not yěm-mă; ěs kě lē jěp, the eggrs have hatched; ès kě lè yĕm, the egg has hatched (i.e. given birth to a child); sār kě jëb = ten with its children, i.e. the number's over ten and under twenty, e.g. 11, 12, 13, etc.; jěp-pè-mă, the stones like marbles, which the gŏ-pè, or diviners, or fortune tellers, use in their work.

jĕrm . the placenta, or afterbirth.

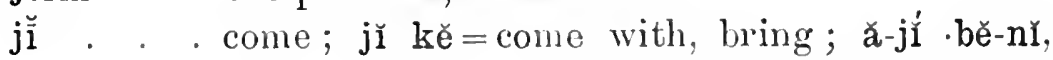
come here; ă-jĭ kě brüng-dă, bring the horse; gwŏ-jŭ-jŭ, a stranger, a comer. Śee gwơ-lě-lě.

$\mathrm{ji}$, better a fool, irliot.

$\overline{\mathrm{d} j \overline{1}}$

jügwěl. . II. aljinnu, the local spirits, genii lororum, contracted at times to "gwěl; jĕb mă düm gwèl, the boys liave been to the spirits (said if youngsters come home and are unwell, as being supposed to have played with the jigwel, who have given them something bad to eat); gō-kŭn kě nē kā, grown up people do not see them; wŭs kĕ jŭgwěl, vapour; jĭgwěl mă găm ğhā, or, jĭgwěl mă lăp dō-fā (id.), the jigwel ane imitating you (silil of an echo); nin pì, the local spirit of a house; jŭgwěl mă rōt gŭrm, bě mă tŭ-tū, if the jigwel like a man, they kill him. The jigwel are by no menns amimintic deities or supernatural beings to be worslipped ; they are merely another form of cration inhabiting the world; but they are propitiated and feared to some extent, as, being invisible, 
they can play tricks on men without being injurel in return; by means of the jigwel the Angass explain away many small effects, e.\%. headaches, echoes, etc., which would otherwise be unintelligible to them; wŭs jügwěl also is the fire made by friction, generally by rapidly twisting between the hands the pointed shaft of an arrow through the pith of a guinea corn stalk; it is so alled because it is one of the things the men keep secret from the women in order to retain their hold over them.

jŭjăk . a rely resinous tree, from which torches are made $=$ H. ma-aslita.

jĭjí . . the pupil of the eye.

jŭjĭ . . beings of the nature of jĭgwěl; they only make their presence felt at the time of mǒs-tār.

jŭjĭ . . a long-shaped drum, the head of which is made of the skin of the pẽp only; used in conjunction with jŏk as a 'juju'; the blood of a fowl is washed over the hand, and a smooth guinea corn stalk is pressed against the skin of the jĭjĭ, and the hands are rubbed along the stalk towards the drum, causing a booming sound, which can be heard at a great distance; the effect proluced is the same in principle as drawing a wet finger along the elge of a finger bowl, but the latter not having the drum or anything to act as a somnding board makes no great rolume of sound.

jĭmín . . sometimes zĕmĕn, the orlinary worm $=\mathrm{H}$. tana; a worm, in general; intestinal wol'ms; the tape rol'm (?).

jīr . . bar'ren, of a woman; sterile, of a man. 
jīr . . a spindle; mŭ chin jīr mŭ tăt pŭtŭk, we make a spindle, and spin cotton.

jō . . a female of a species of a lizard; male $=$ gwŏjō, q.ル; H. ju; wŭs kĕ gwŏ-jō, va pour.

jŏk . . to tickle; any ticklish part of the body, especially below the armpits; rīp-dă kä-dổ-dör, ŭ-jŏk, kō nyī shwār, kō nyī shăng sheūkkèni, the girl is cross, tickle her, to make her laugh, and become pleasant. See $\overline{d j}$ jok. jŏk ol a species of 'juju' or 'melicine,' e.\%. if a djok woman leaves her husband and goes to another man in another town, an old waistbelt of her's is taken and wrapped up in a mass of tŭlắn leaves, mīl grasss, or mắs leaves, well sprinkled with fowls' feathers; it is then tied, by the priests, like a flag to a tall tree close to the woman's new town for all to see. The new husband in fear, at once returns the woman, together with a goat; a similar performance is enacted for a theft. See jŭjı̆.

jölĭ . . the small brown monkey=H. bivi; in a song occurs the vel'se jŏlĭ sŏng gŭrm = the monkey wiss changed into man, which is said to indicate a belief in a common origin.

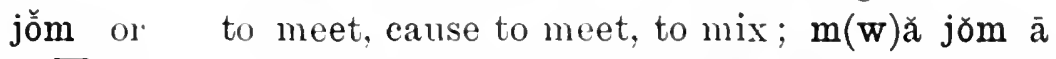
$\overline{\mathrm{djo}} \mathrm{m}$ dăng, kō nyĭ chĭn lěŏk dí, when one has mixed (poison) thus, one groes to fight; to collect; to put together to make one; bāt shwē kŭk, ăn-jōm kwān, bě ăn-ḡhür, this bundle of guinea corn is ridiculous, I can put three (such) togrether, and carry it.

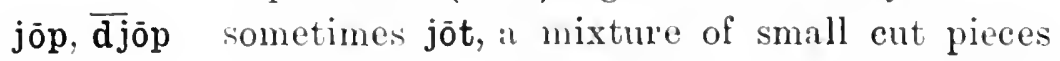
of meat, salt and 'mia'; not, ipparently, known at Ampier.

jop . . to trot, of a horse. 
jŭk . to smile; gwŏ-dă gwŏ-chăn, mă pŏ jŭk-kĕ-nĭ veng. the man is amusing. one is always smiling at lim. See shwār.

juik . . Il. livia, a tree from which tobacco pipe-stems and charcoal are marle.

jük . . . in the phrase ă-dăm jük = jump strongly. jür . . jealousy, envy, malice; pŭt gnăn shř jūr, he has libelled me; jĭ kě dō. pī jūr, he brought the complaint. out of spite; măt-dă-mă mă pŏ chĭn kĕ jūr kă shăk, the women are jealous of each other'; jūr lĕ nyì dăng kĕ lì, jealonsy made him say it. $C f$. H. zuı'.

jwăk . the shaving of the hair orer the sides of the head, just over the eyes and temples. It does not go far back; only done by boys and girls, but not by grown up people.

jwăk . the ivory armlet or biacelet, worn only by high officials, i.e. the lring, or one of the mǐs-kām-fïr, or elder's; they are obtained

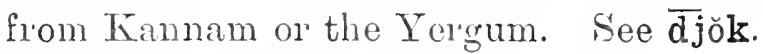

jwăl . a rocky hill; any rock too big to move. jwăl . a string bag, all white; jwăl chīp, a similar bag, but woven black and white patterns; both these bags generally have shoulder straps, and a certain amount of tasselling ol fringes (H.A.). The P.A. word is kăjeung.

jwăl . to plant, to put, in the ground-of stakes. jwār . thigh; sometimes ājwār.

kă . . our ' $a$ ' in a-loft, a-hor'se, etc., thus, ăn-nĕ nyı̆ kă brüng, kă kĕ, etc. = I saw him a-lıol'se, "loft, etc., i.e. on a hor'se, etc.; also = the H. ' $a$ ' in $a-g a b 7) a=\mathbf{k a ̆}$ pŏ-kīn, a-haimya= kă ăr, a-gidldu=kă lŭ, etc.; further, fol- 
lowed by the reduplicated verb it gives a participial, or perhaps adverbial, sense; $e . \%$. kă lảng lăng $=\amalg$. a-tsu!nuen, a-bent, or benulingr ; kă sŭ sŭ =a-!/kje, a-1'm1nning.

kã . . at the encl of a sentence turns it into the negative form; mă măn=they know; mă măn $k \bar{a}=$ they do not know; $d \bar{l}=$ there is $=\mathrm{H}$. alinoi: dí-kā, thẹre is not $=\mathrm{H}$. babu.

kābē . perhaps, possibly: kābē jǔ kā. perhaps he will not come; also ābē.

kăbrăk see kăfălăk.

kăbüs . the paw-paw = H. freancla.

kăbūt . . the whole, entire, complete; ă-pün gnăn kăbūt. măn ă-yřt kō găk, give me the entire lot, don't leave even one. See büt.

kădắk . not thus; also used for an emphatic kā, not; nyì dò dā $=\mathrm{H}$. shi lie nan, that's right; nyì dō dà kădăk = that's not it at all! sheurk tŏk-dă kăt ğhā kădăk; the discussion has not reached you at all (said to a listener. who is paying no attention, or is busy picking a sore, etc., instead of listening); mă pǜn zin gŭrm pī rōt kădăk, one by no means believes a man merely because one likes liim; ŭ-tŏk bĕ ŭ-tǒk ă kădăk, if you do do it, do not do it thus, i.e. of a discussion, i.e. tǒk.

káfălăk , a term of abuse =having skinny or leatliery buttocks; ; ilso kăbrăk.

kăfắlăk . H.A. for a ponỵ's colour = H. gunya, creamcoloured.

kăgŭk . the back, more especially the lower portion.

kăjeung . a white bag male of string, slung from the shoulder's, used by men and women.

kăk . . to ward off, protect from; ă-kăk pí-pĩ-dă. 
măn ăm tŭm, protect that spot [e.\% a doolway], lest the water come in, or descend.

kăk . an exclamation, generally used to give notice to others, of game having started up in their direction; wŭn kăk! 'mark over!' look out! ŭ-kăk! măn tē, look out! lest it fall (a tree, pot, etc.).

kăk . a particle; ŭ-dār kăk kwăn-jŭ, wait quietly until I come.

kăk . . to put in line, or arrange; ŭ-kăk păng, make a fence of stones; to take away, and ar. range in a pile, the stones and rocks from a farm, to leave room for digging; kăk păng găng, pile up the stones. See kwǒk.

kăk . . to think, suppose; mŭn pǒ kăk kĕnĭ, kō lăng bŭt-nū dăng, we suppose so, but wait till we take counsel, or, think over it; gnăn pŏ kăk kĕnĭ, (I am not sure) I only think so.

kăk . . to ill-use; mă kăk-ăng kŭk, they are seeking to ill-use me (but I don't know what for) -said in indignation, or as a complaint; ŭ-kăk gnăn ākŭk, you ill-used me for no reason.

kă kế kĕ . H. alian=concerning, with regard to ; lit. = on the head of ; kă kē kĕ mē wŭn pŏ kör è ? what are you fighting about? lit. on the head of what are you fighting?

kākŭt . one lying helpless, from sickness, lameness, an accident, etc.; kě bār kākŭt, kō kĕ yāl kâ, he has become helpless, he cannot get up.

kălăng . the woman's hut, with two door's, front and back, in which she grinds her corn; the 
entrance hut to her suite of liuts; each wife has one.

kălüing . hawk; IT. sllivuc; ŭ-lăb kălüng-dă kăk, măn dăp kì-dă, hrive away the hawk, lest it take the fowl.

kălüng . to hear and understand (H.A.); ă-kălüng kā, don't you understinnd? ăn-kălüng kăs, no, I don't. H.A. and Sura.

kām . . strong, strength; well, in good health; gahā kām à? are you well? kām kě gŭrm kè chǐn kō(n) kām kĕ kēr kā, the strength of a man is not like that of a monkey; mǒs-ň kăm dĕl mŏs-nŭ, this beer is stronger than that.

kām . to be strong, to exert strength, to seize, to press, to squeeze, to throttle; kām pǒ chǒk gnăn, it grips my throat; to seize with anything (e.\%. teeth, mouth), except the hands, which is yē; ăs kām gnăn kè às, a dog seized me with his teeth; pī-dă kām dung, the place is very narrow (as of one of the old worn paths, well below the surfice of the ground); bŭt kăm gnăn, I have a stomach ache; mwām kām gnăn, an insect has seized, i.e. bitten, me; = II. liama.

kām . H.A., a crowl, people.

kămwı̆n. H. muchice, a stick for stirring the contents of a cooking pot, especially mŭn.

kān . . to snatch at, sciamble for.

kănchăn . those who (lo not eat hawks (kălüng) : applied especially to Ampan, but also to Lur and Gumji.

kăng . to collect, to join, to be collected; ă-kăng mă. get them collected = 11. !/amma; mè kăng wŭn kĕ gō-ămă dăng ŭ-kor è ? lit. what joins you with your family that you 
quarrel? i.e. What is the cause of the quil'rel with you and your relations? mŭ kăng gō-ămă kĕ kwăng pŭp, we join relationship of, or with, the father's side, i.e. we are relited on our fither's side; mè kăng wŭn è, whist joins you? i.e. what is your relationship? pŭp kăng mŭn, the father joins us, i.e. we are related on the father's sicle; similarly, nin kăng mŭn, on the mother's side; pŭp găk nĭn găk, our father and mother are the same: pŏ kăng, expecting to join, i.e. waiting for ; gwŏlŏng Păm pŏ kăng kĕ păk kĕ mĭskām-kěnĭ, the king of Ampam is waiting for the rest of his chief men; mŭn pŏ kăng-fā, we are waiting for you; mŭ kăng kă-dün dŭng dŭng kō mŭ tǒk, let's wait till we are many befor'e we start talking; a joint; kăng sār =the wrist; kăng kĕ jĕp săr=a finger joint; b̆̀-chĕ kăng wŭn à? what is the matter between you? - the first question put by the judge to the litigants; kăng $\bar{a} r$, a junction of roads $=\mathrm{H}$. ma-gammin hainya.

kăngŏr . snore; sometimes găngŏr; gwŏ-dă nyŏk, or, děăng, kăngŏr, the man snores; kĕ sēm kwō děăng kăngŏr, he is sleeping (in such a position) as to snore; ă-mwăt kō nyı̆ yı̆t, slap him to make him leave off; or, ă-děn nyı̆, stop him (snoring).

kāp. . sandals; kāp fŭt, lit. a shoe with a deep hole, i.e. the long riding boot. The villages of Kărwăt and Fifi still make them for Kanam and Duguri, an industry apparently known by the Angass before they entered the country. 
kăpăn . a ghost, but only of those who have died as witches or wizards; in form it is like a diminutive man or woman about 2 feet high, visible, however, only to few; in nature it is a waling forlor'm spirit, capable, however, of being a nuisunce to mortals; its span of existence is not more than a month, when, if it has not met with a violent end from a $\log$ or a hawk, it eraporates and ceases to be.

kă-pi-dă . II. a unuri nan, at this, or the, spot.

kă-pī-dǒk lit. H. a uuri dī, H. tun=since, or, before; or -dōn kă-pi-dōn mă (kă) lěngăn, since they bore me, i.e. since I was bor'n; kă-pì-dōn mŭ kă jī $\mathrm{ka}$, befor'e we came, lit. at the former time we had not come.

kăpkŭl . tieggelafus gintus, the bush buck = H. mazo. kār. . to tamper with, especially of another man's fiancée; to deceive; gwŏ-dă pǒ kār kĕ rīpdă kõ nyì lă dĭ, the man is tampering with the girl, to marry her himself.

kār. . to punish.

kār. . a shelf of mud, built on to the wall of the hut. See shǐkār.

kărăm . . See kărm.

kărăng . a man; but the word is applied especially to the Angass themselves; the rest of the world, with exception of the Jukons, who are kwip, is styled somewhat contemptuously 'lăp-mă'; at the same time if an Angass man, in a Hausa town, sees any pitgans, whom he recognises as such by their being ' fia' or beer' drinker's, he will call them kărăng-mă ; mankind, as distinguished from the brute creation. S'eo kwip.

kărăng a species of calabash = H. uauan !froma. 
kărăng . meaning; ă-găm sheưk kărăng-kěnĭ gnăn, show me its meaning; ğhā kě shēr-kū kărăng kā dŭng, you have no sense whatever (saicl to a man who is a fool over his work and spoils it).

kărbăk . the hyena; ăs kărbăk, a black-and-whitespeckled dog.

kărgŭn . H. liuive, a shrub, whose branches are used to make the jinia (H.), or circular bands, of the roofs of houses; its leaves also are used for thatching; mă chōt k $\overline{\overline{e u}} \mathbf{s}$ kă dŭk lŭ, kō mă lě kărgŭn dí, one twists up the circular bindings for the roof, in order to put the 'kargun' branches on top of them.

kărm . . a 'zana' mat in the process of making, or' before it is put to any actual use; after it is completed and put up on a house it is known as kwŏm; made from the grass mil. kărm . . to cut (of anything big or important), as a tree, a goat's or a man's throat.

kăs. . H. gayamba, the grain food; mŏs kăs kĕ tŭ pì bŭl, 'gayamba' beer is very potent.

kās or gās to refuse to do, or dislike doing, a thing, and so to omit, or fail to do it; ă-gās lěb dŭng, you dislike being sent; ă-dŏk kās, keep silent, refusing to answer.

kăs . . H.A. an emphatic kā, or no; also used among the Suras.

kās, in apparently a sort of surname of a whole pŏ-kās family, but applied only to the females; the males of a family, whose females are pǒ-kās, are all called jĭgếs (Ampam).

kăsăm . . see under pē.

kăsăng . a sieve, filter ; mŭ shăk mŏs shĭ kăsāing, we strain the beer through a filter. 
kăsběn . hrass; kăsběn gŭng, copper; mă lă kăsběn kă lă-ghhit, nne puts brass (ornaments) on the wrists.

kăss . . abuse, cursing, defilement; II. at!je and lictsarcutce; kăss pi kŭk, he curses everyone; kăss kŭm, abuse of kŭm, i.e. blasphemy; also kăss worng, kăss nĕn, etc.

kăt. . to find, obtain, get; with the negative it means 'to lose'; ăn-kăt chŭk kāa, lit. I to not find the knife, i.e. I have lost the knife; ăn-gī wăt, dăng ăn-kăt, I have looked for' the thief, and have found him; mă chin shĭt, bĕ mă kăt äng, if they do work, they will get pay; ăn-kăt chŭm kă ār, I found it on the road.

kăt . . an explanatory particle = perhaps, it may be ; kăt gwor-chě mūt-n-chā? it may be that some one has died, eh?

kăt. . H. Ficulda, lest, that not, the negative imperative; ă-jī kăt, lon't come! ă-kăng mŭn kăt, don't tie us together; also userl with măn, e.g. măn ă-jī kăt, clon't come.

kăt! . an exclamation of surprise, and anger ; kăt! kăt! kăt! sōt kě răn ghā, you! you! you ! witchcraft has made its pattern on you!sail in great anger, a very extreme form of abuse, which might easily lear to knives being drawn and blood shed.

kăt. . generally reduplicated, bad, wanton; măt kăt kăt, a wanton woman.

kăt. . . to wander about; ăn-kăt ākŭk, I am merely wandering about aimlessly.

kăt. . . to happen; see yrut: mē kăt ghā, what has happened to you? - but only used in this sense when followed by an object. See pŭt. 
kătălăng a a haren woman.

kătălăng . very long a⿺ro, in the resy beginning; kătăläng kĕnì mŭ nē bì-chĕ kō kō nyĩ kã, from the very beginning of things we have never. seen anything like it, or like him, or like her.

kătẽum . a small basket= H. Iulu (and lialimi?).

kè . . . a heal (H.A., Thīl, ete, kā, ff. H. liai); adv. above; to climb, mount; kē-fā wărn dŭng, your heal is big, and also, you have a 'swollen head' (abuse); kē kĕ gwŏ-dă kĕ-n tūl, the man's head has a wen, or swelling, i.e. 'swollen head'; mŭ kē jwăl = we climbed the rock; shĭ kē-fănă, etc. $=\mathrm{H}$. da liai-na, I myself, reflexive pronoun; to put upright, to plant; ă-kë ğhk, set up the stone; kē băng, a clean shaved head; dük kè, to wag the head; kè ăük kē kõ gwojjo, he wags his head like a lizard; têt kè, to norl the head rigorously, but only once; yit kë, to wag the head from side to side, in dissent; ă-tē dăng ă-y̆̌t kē, you refuse, you shake your head; bě kě kèe, to turn the head aside, as in contempt, so as not to see.

kĕ . . prep. of, with; sometimes pronounced keu, for symmetry, and at times followed by an euphonic '-n'; brüng k kü-n gwŏ-lŏng, the king's horse; frequently left out where we should expect to find it; pŏ lŭ or pǒ kě lŭ, the door of the house, thus corlesponding to our construction 'house door'; ăn-tŭ nyı̆ kĕ kwŏp, I killed him with a spear; ăn-jī kĕ dōo, I come with a complaint; corresponds with the $H$. ' $n a$ ' in the 'continuous' tense, e.g. gnăn kĕ rōt kĕ ăm = 
i-na so $n(a)$ rua, I am wanting water, lit. I with wanting of water. 'l'his is the original construction in the H.A., Lankan, etc., but in P.A. the first 'kĕ' has griven way to the mo1'e illiomatic 'pǒ,' 'a mouth,' e.! gnăn pó rōt kě ăm = II. lit. ni haliin so-n rua; used in the sense of 'and'; chinñ kĕ dí-děr mă Něn, to-day with to-morrow (i.e. and tomorrow) are Ciol's.

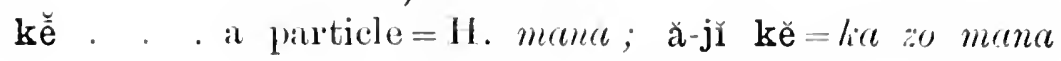
(11.) = come along, hurry up; ă-lí kĕ $=$ speak up.

kēl. . to meet from opposite lirections, ats a man, hunting a leopard, being eharged by the latter ; to stumble, knock up, against; kēl shì, to trip, stumble (over it visible object as a stone, tree, etc.); see gŭ; mwěn-fănănĭ ăn-kēl shĩ kě shì büs, in my walk I stumbled badly.

kèl . . to wander aimlessly; tó wander about the bush like a madman, with one's clothes off, and shouting.

kĕm . . the ordinary cactus of the town fences; more general in the H.A.; the P.A. word is $g \check{u}$.

kēm . H.A. for a harmless madman.

kēn. . II. iri, seed; kinul; sort'; bì-dă kēn më? what sort of thing is it? or, kēn-kěnir răng $\overline{\mathrm{e}}$ ? kèn shwè = reetls of the guineil corn! gwǒ-dă kēn kĕ mă kēn kě gŏ-sōn-mă, the nature (kincl) of the man is such that all his progeny are tall.

kẻn. a palisarle, a fence: chĕn pó kēn, to build : fencer.

kèp. . H. !oglo, the big baboon.

kēp. . . a fin of a fish. 
kēpăng . moklestỹ; good mumuers; shy; kēpăng ăng dŭng, I feel very slıy'; nyì kě kēpăng kā, he has no mamers; yèm-măt-dă lì sheưk tơk kā. pī kēpăng (or; kēpăng ny̆ dŭng), the girl does not speak, from modesty; yī măt-nĭ, kēpăng-yī kā dŭng, yī nē gŭrm-mă, bě yī sĭt pī mē ? yī wŭl fŭng kō yī pŭt! here you woman, you have no modesty whatever, you see the men, why do you pass by? go through the back door and get out!

kēr. . a smallish black and white monkey; gwŏklǒk kě yĭt, kēr! a line of a song $=$ ' $O$ monkey with the deep-seated eyes!'

kerrbük . the wild banana found in the Hill Angass; (not fit to eat).

kĕsh $\breve{\text { euk }}$, see kĭsh $\breve{\text { euk }}$.

kēt . . to meet; ŭ-kēt măzěp, go and meet the stranger. See kēt, a boundary.

kèt. . a female that has never given birth (only of animals); yĕm kĕ kēt, or yĕm kēt, the first born (of animals).

kēt . . a boundary, a limit; dēr mă lěŏk pŏ kēt kĕ mār, people will always (lit. to-morrow) fight over a farm boundary ; ă-chĭn kō nyı̆ düm pŏ-n kēt-fā dì, lìt. do (it), so that it is finished, to your limit = lo your utmost ; $c f$. H. lietcre, and see kèt, to meet.

kèt. . to look after, of a fire; ă-kēt wŭs, măn pīt, look after the fire, lest it go out.

ket . . a debt; ă-ăng kēt-fănă gnăn, pay me my debt; a loan; kēt-dă ăn-pün ğhā ă-pünğăng, give me the loan I gave you (ă-pǖ̄năng == ăpün-gnăn).

kět kĕt . an emphatic particle, absolutely, completely, entirely; sě yĭl-fŭnŭ kō pŭk mŭn kĕt kět, 
he conquered our country and desolated us completely.

keüm or to play, frolic, as children; to sing; ă-lă küm,

küm sing (to us); keum tār, the playing month $=$ mǒs-tār ; shěuk rìt (bís)-fā kăt ğhā (dăng) ă-lě (pǒ) kě keüm, good fortune has smiled on you and makes you sing (bis when used is ironical).

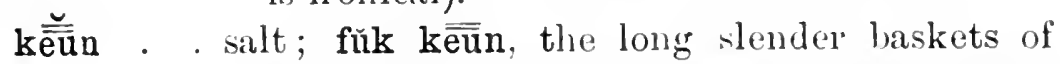
salt; dăm kēūn chĭn (or', yē) gnăn dŭng, the lust, or desire, for salt is on me, i.e. I've had none for a long time.

kēun or kün $\mathrm{H}$. Jauna, the bush cow.

keurror kürr the silk cotton tree $=H$. rimi. There is at Ampier, in the semi-Hausa quarter of Chikki, a cotton tree where all sales of slaves used to take place. The following dialogue might have been heard: 'Kwămtăk lām à?' 'Lām.' 'Lì-fwǒt pī-kěnì kā?' 'Mă fwǒt, nyĩ tōm keưr ; kŭdr̃ kă yı̆l dō dă; ŭ-dār kū lă ny̌r.' 'Is so and so missing?' 'Yes.' 'Have you not heard where he is?' 'Yes, at the foot of the cotton tree; he is still in the country, make haste and get [i.e. ransom] him.'

keür . . doubt, suspicion, fear, awe; keür mŭn, dăng .bĕ dí, he doubted us, and went back; k keur mūt, fear, terror; the fear due to embarrassment in the presence of a superior, shyness, nervousness; ăn-keür nyī, l was nervous in his presence; ăn-keưr müt-kěnŭ, I was in terror of him.

kềs . a carrier's head pad, placed under the loat ; it is circular in shape.

$k \overline{\overline{e u}} \mathrm{~s}$. H. auta, the youngest child, m. or f., of a family; the little finger. 
ki . . Jusl land, unfarmed and overgrown with shrubs, trees, griss, etc.

$\mathrm{ki}$. . a fowl; dîl kī, a cock.

kì . . liver, better, kī năm. Nèn yē dèn kī kō nyī chăk tōm dĭ, God put in the liver to collect the blood.

ki . . to protect, to ward off; ki yit, to put up the hands to protect the eyes; ăn-ki yit, I will protect my eves (and also, myself); ă-pün kün-gĭrp gnăn, ăn-kī păs, give me a shield, I will ward off the arrows; ă-kĩ pó lŭ-dă, defend the door; also, to surround and catch, as a goat or hen, by a circle of men, with outstretched arms; kī-n-pin, a place of shelter, or a refuge.

kiăk . a porcupine; păs kiăk, a porcupine's quill; ăn-nē kiăk, dăng ăn-dăp đăm dĭ, dăng ănmwăt dĭ, dăng nyŭk kă gŭk dĭ, dăng pŭs ăng, I saw a porcupine, (then) I took up a stick, and (then) hit it, it (then) curled up its back, and (then) shot me.

kĭbǐ . . to hatch; to hatch out.

kilìwŭs . the fire-fly.

kim . a small drum $=\mathrm{H}$. yayan surmi; two of these are generally placed together close to the big one (nin), and are all three leaten by the same man; ă-tŭng kīm, kwă-tŭng nìn kwădă (=kwăt à), ḡhā bǐ-shēuk-ḡhā ? do you beat the little drum, as well as the big one, all by yourself?

kìmi . a tree resembling těung furr or the H. chedia.

kìmī . evidence; a witness; shĭm wăt dō kīmī, the skin (of the beast stolen) (in the possession) of the thief is evidence; kwămtăk dō kimi-fŭnū, so

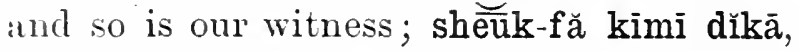
your statement is no evidence (is in'relerant). 
kìn. . front; pǒ-kīn, a forehead; with pè; kin pè, victory, succesis, to be successfiul; kin pè-fä, gwơ-lơng, kărăng-mă mět shĭt kō mă bě zŭm kěsheurk (your forehead is white, i.e.), you have had a vietory, $O$ ling, the men have gone to the battle-field (bush), and have all returned safe. See pè or pyè.

kīn. . straight, right, accurate; gwŏ-dă lí gōl-dă kin gnèt, the juulge has given a correct decision; àr-dü düm kīn, the road goes straight; kě-n kin dō dă, that's's quite right.

kip. . the sheath of a knife; kip chork-dă kăt, or kip-dă kăt chǒk-dă, the sheath is too long for the knife.

kir . . a ram, kept in the house for fattening purposes.

kïr. . . to tend, as of cattle, etc.; bì kỉr, cattle in general, everything fed, e.f. cows, ponies, goats, fowls.

kìr . . . to do a thing on purpose, or', for no special reason, as a baby crying; ă-tŭ gwó-dă shĭ kīr, kŭk, you killed the man on purpose, for no reason.

kirp . . to turn a thing, such as a pot, over on to its mouth; also to shut, to close, cover; ă-kĭrp pro chèlè, close the month of the pot; ă-kirnp kō nyĩ rīt dĭ, măn bĭ-chě mă sīt dĭ, tur'n it over properly, so that nothing can get inside; to shut out, to ward off; to hold something, e.\%. a shieh, in front of one as a covering or protection; sometimes pronounced giro ; ă-kŭrp shĭm kă kē-nā, cover my heal with the skin (sail by a thief asking to be confronted with the proof of his theft), i.e. with the skin of the beast 
stolen, and hence used in connection with any theft; 1 . covering, protection; of. H. liirfa: kìrp kē shĭ fătăt pī gwŏ-mĭs-mă, she covers her head with a cloth on account of (the presence of) the men (only among such of the Plain Angass as own a cloth).

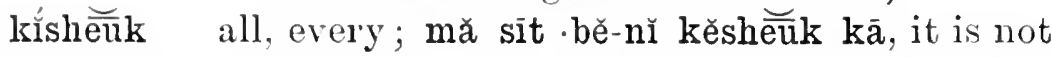
or everyone who enter's here; mă băm lŏng késheưk kĕshe̋ k, they have seized everything. In the H.A., and in Thal especially, dǔk dŭk is used instead of kĕsheukk.

kìs . . a rough surface, such as a stone, an unglazed wall of a hut, etc.; not smooth.

kis or kis one of the combination of marks made on $\mathrm{pe}$ the ground by the gŏ-pē in his divinations. See pē.

kō . . . like=H. liaman; gnăn kō(n) gwŏ-lŏng, I am like a king; gwŏ-chĕ kō nyī kā, there is no one like him.

kō . . . with the verbal forms of the pronominal prefixes, forms the subjunctive mood, which is also used for our infinitive; perhaps in origin it is the same as the preceding; ănrōt kō ăn-mĕt, I wish that (like) I may go $=I$ wish to go; kō ăn, generally contracted to kwăn, kō ă, to kwă (2nd pers. sing.); kō ŭ, 2nd pers. pl. to kū ; ă-pün jĕlmăt gnăn, kwăn-mĕt sīt br̆ sẽ dĭ, give me money that (or, like) I may go (or, to go) (and) buy food.

kō . preceding an adjective, a numeral, a sentence, etc., transforms it into a substantive; thus nēt =red; kõ nēt =a red one; găk=one (the numeral), e.!) brüng găk= one horse, but kō găk gū, one fell; dŏk mūt = he died formerly, or', some time ago, but 
kó dork müt = the one that died some time ilgo.

kōdăng . with shǐ = when? shí kō-dăng kě jĭ ? or better,

kè jĭ shî́ kō-dăng? when will he come? See Grammar. Chap. x. 2.

kǒkŏr . H. Iila (?), a fox (?).

köl. . crooked.; not straight, the wrong way of

doing things; ă-chĭn kă-kōl, you have done it wrong.

kōl . . . a criab=H. liąura; also kō̄l.

kōl . . anything that supports anything else over a gap, such as a tree across a stream, a bridge, the rafter's of a roof, etc.; a support; kōl shī, a support for the foot, i.e. a 'leg up' in mounting a tree or a horse; also $=$ the feet crossed in sitting with the legs straight out.

kōl . . to give an opposite comer the road, to get out of his way; ă-kōl nyī, make way for him.

kō-mē . . H. komi, anything, everything.

kör. . to quarrel, wrangle, to have a rough and tumble; mă kör mă rĭb shăk, they fought and separated; ă-kỗr nyı̆, fight with him; kě tơk shwār, körr dì kā, he is joking, there is no quarrel; to fight; $\breve{u}$-kör kē! you fight, do you? said by a would-be peacemaker'; mŭ kōr kē, yes, we do, and mean to! cf. H. liore.

kō-răng? how? how much? how many? mì-ghā kōrăng è ? ol', kōo-răng kě mĭğhā dē ? how many are yours?

kō-wē . H. liova $=$ anyone, everyone, H.A. = kō-wā. kŭdăng . for kŭdí dăng or kŭt dăng, still, again ; dēr ăn-kŭdăng ăn-chinn kā, lit. to-morrow I will again I will do it not, i.e. I will never lo it again. 
kŭdĩ . eontincterl to kŭt $=11$. tuliuna $=$ not yet $=$ and also = still ; kŭdí găng, not yet lijpe, or', still muripe; kŭt pó nyŏk, he is still breathing ; măntă ă-jī kăt (n) kŭdr̆. don't come yet; used also as a verb; ă-kŭt (or ă-kŭdì) ă-chīn shǐt-dă dăng kō ă-mēt, lit. H. lia tuliuna lia yi ailim lianu lia trefii, do your work, finish before you go; kŭt bĕ-nı̆, he is still here; kŭt (or kŭdù) dăng kě $j i ̄$, he will come soon, or, he will still come.

kŭk . worthless', useless; $\vec{a}-\mathbf{k u ̆ k}$, in vain, to no effect, lit. thus useless; occurs frequently as a term of abuse; ă-gwǒ-nĭ ākŭk-chĕ băng, you are a useless fellow altogether; kō-mē kĕ lĭ răng ē, răng ê, tŏk kŭk, whatever he says is worthless (or, useless, in vain) ; tǒng-fănă tŏng à-kŭk, lă kě kē gnăn kā, my stopping here is useless, no one takes any notice of me.

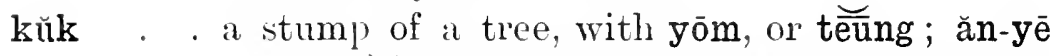
kŭk těّung kwăn kē, I seized the tree stump to climb it.

kŭk . . to bark; ăs-dă kŭk pī, the $\log$ barks at some movement (7it. at the place).

kük . . exactly, used with numerals; tyĕrk'sār kǚk, exactly 100.

küll . . to tie a knot, a knot; H. linlla, liulli; kwāl, is more, to tie a lot of knots.

kūl . . H. gauta, a fruit like a small tomato.

kŭlés . a small bag made of the whole skin of a young goat by piercing its throat and then drawing the whole skin off like a glove.

kŭlŭk . . al leather bag; H. bur:/ami; bi kŭlŭk, something in a bag-said of a present a man is taking to his future mother-in-law; but to 
avoid exposing himself to chaff, he calls it bỉ kŭlŭk.

küm . strong, musculint, thick; applierl only to a few animals, e.\% dog, monkey; not to ponies, cows, goats, or sheep; kō-nĭ fil fil kōoni küm küm (or tōn tōn) this is thin but that is thick.

kŭm . If vari, i.e. all the ritualistic ceremonies, wor'ship, reverence, etc., pail to the objects of devotion, but only of the lesser and more personal influences or spirits, i.e. the household ones, and only in cases of minor and household, not tribal, matters. It is also the name of these lesser influences, anl corresponds to the 'household gods' of the incients; mă pŏ chĭn kĕ kŭm $=H$. suna yin wari, they are at their derotions; Nĕn (Goll), Wong (Nemesis, or the executive (leity), jigwel (the local spirits), are all more potent than kŭm, but kŭm takes

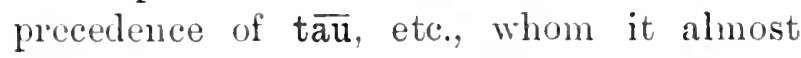
inclucles; sě kŭm, to swear, to take an

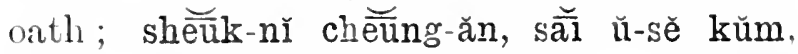
the matter perplexes me, (there is nothing for it) but for you to take an oath (abont it); măt kẽ bĕ, mă küit kŭm-kěnİ-mă dăng kō mă lr sheǔk kěnir, a widow, until all the (funeral and other) ceremonies are completed, one does not talk (marriage) to her.

kum . . tinder malle from the silk of the cotton tree; ngăss-mă mă kăt wŭs shĭ măsănă kè kŭm, the Angass get fire with flint and tinder; ă-mwăt măsănă, kŭm dỉkā, bě yē kā, if you strike the flint, and there is no tinder, it will not catch (fire). 


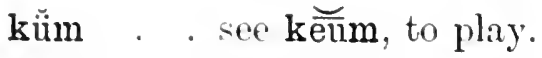

kuim . a colpse.

küm . the natvel; mă mwăt bŭt küm mă müt, if one is hit fairly on the navel, one dies; gŏ-kūm, f. nă-kum, a man with a protruding navel. küm küm . tholonghly; well; ŭ-lăp küm küm kù-dür mă, look into it thoroughly and arrange it for them $(\mathbf{k} \bar{u}=k \bar{o} \breve{u})$.

kün . beer, or mŏs (H. !/ $/$ ), which has stood one night after the brewing is completed. See nŭng.

kūn . a black and white snake; it frequents houses, but is not killed there, but if found in the bush it is killed and eaten. H. ganwo.

kün . . to push out, to for'ce out; applied to a woman at child-birth. See yěs.

kŭn . greatness, honour ; pün kŭn, to do honour to ; düm pün kŭn nyi, he honoured him to the utmost; gō-kŭn, the chief man of the party; wā dō kă-dün-fū gō-kŭn à ? who is the chief among you?-great, big, old, applied especially to the elders of a tribe; shwe kŭn tŏng $k \bar{e}=$ the corn is big enough to plant out, lit. the corn is big, it suffices planting.

kŭn . . in the abusive phrase, zŭm rŭs kŭn, a humpback, or an old bent man; perhaps it is= kŭn, big, and here= 'big bent back.'

kŭn் or a tree $=\mathrm{H}$. baushe.

kŭng kün . see keün, the bush cow.

küng or the edge, brink.

pǒ-küng

kŭng . . the big drum = H. tamberi: mă tē kŭng, they beat the big drum (with two sticks); it gives a booming sound. 
kün-grrp . a shield, made of skin; rf. H. livengura; no other kind is male; derived from kü̉n, : buffalo, and gurp (kirp), it covering, protection.

kūp . to thatch; mă kūp kărm kă kē lŭ, thrẹ̣ thatched matting on the house, i.e. they thatchel the house with matting.

kŭp . to close tight, to shut up, as of the fist; ă-kŭp, măn mă nē, shut it up (or, wrap it up), so that no one may see.

küp . the long knife, almost a sword, worn at the waist.

kŭr. . . a deep pool, out of depth, which lasts all the year round.

kŭr. . the large edible tortoise; H. liunliuru.

kŭr. . charcoal.

kŭrbăng . H. dubgainya $a=a$ badger (?), also called rim.

kŭrgŭk a food ingredient made by mashing up the inside of the baobab fruit and making is paste of it with water; , the fruit of the lŭnkŭs, also so used.

kŭrkŭjü a a fable, story, not meant to be regarded as

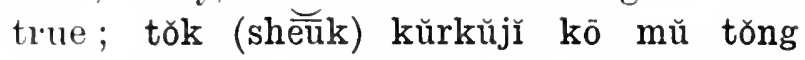
gyerrm, tell a story, so that we may pass the time till we go to berl.

kŭrm . . to kneel; kurrm furm, to go down on the knees.

kurrpăng . according to Angass tradition is the name of the chief town from which they migrated (see kwīp). From information received from some Jukons, it was the nlame of the big Jukon 'T'safi' or religious ceremonial. The word has a distinct Angass sound, for, 'păng' heing is rock, it might mean 'a tortoise r'ock,' or a 'charcoal rock,' or a 'deep pool rock.' The other root, 'kŭr,' 
may turn out to be of special signification,

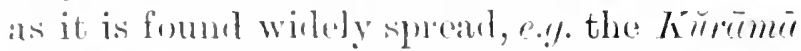
people in Karia, who connect their name with the market 'Brilimrme' in Kano; the

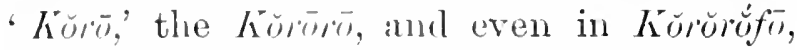
another, and perluaps the best known, name of the Jukons ( $\%$. too the H. karafi, iron; stiong).

kìs. . a grasi, like the fill măt, of which pŏ-bwin is made; superior, for this use, to fill măt.

lrŭs . . a full grown bull, four year's and upwards= H. bijimi ; f. nun nŭng.

kŭs. . to copulate, of dogs only; to be on heat, of bitches only; ăs-dă kĕ mĕt kŭs, said of a log or bitch that is missing.

kŭs . . to remove the hair from the skin, in tanning.

kŭskŭm . an eril-smelling person.

kŭskūm . any plant which throws out young shoots during the dry season, e.g. the tobacco plant.

kut. . an alligator. If it does no harm it is not killed, but if it takes a sheep, etc., it is hunted.

kŭt. . cold; tār kŭt, H. funturu, the cold season.

kït . . . to finish = H. lice; küt, it is finished, or ended; bi-dă kĕ tŏng, kĕ kït, this is enough, it's finished, said to put an end to argument, or to work; rỉb-nǐ küt, this girl is finished, i.e. is marriageable.

kŭtŭl . a sieve.

kŭtung or H. tamba, a grain food. gŭtŭng

kŭtung . H.A. for the H. biti, a good strong horse.

kwāl . a knot in a string; mă kwāl tār, they tie knots for the moon, i.e. the date of the new moon before the harvest is noted, and 
knots are tied on a piece of string so that they may know to a day when to expect the next new moon, and commence the festivities of mors-tār; to tie a lot of knots. See küll.

kwălp. H. ritichi, deceit, to go about with false tales; ă-chĭn kwălp, ă-kăng kổr dŭng, you have acted deceitfully, and set men quarrelling.

kwăm . . see kwăng.

kwām : a robber, a thief who steals with violence.

kwām . . the bent thorn $=$ H. liumlscun shafo.

kwămtăk. 'so and so' $=\mathrm{H}$. wane; kwămtăk mūt, 'so and so' is dead; gwor-dă mă tǒk shēuk kè kwarmtăk, the man spoke to 'so and so.'

kwăng. . a side, direction, portion; kwăng yěl ō! an exclamation in war = that side has been vanquished =our ' that wing has been defeated'; ă-pün kwăng găk gnăn=give me a portion, or, a half ; ă-mět pó kwăng-pănă, go off in that direction; $=\mathrm{H}$. gefe, brink, elge ; tăm rŭ pó kwăng, the boat reached the bank; kwăng sār, the finger's of the hand; kwăng shì, the toes ; sometimes pronounced kworng. and kwăm too has been heard; mă chĕn mŭn mă kwăng, they enclosed us on all sicles; mŭ nē mă pó kwăng, we see them in all directions; ji kwăng Bŭkúr, he came from the direction of Bukuru.

kwăp . H. daidai = găk găk = the same; mă(n) kwăp, they are the same.

kwăp kwăp thoronghly, precisely.

kwār . gravel, very small stones.

kwăs . H. liurzunu, a species of calabash; dē kwăs, the bowl formed from it.

kwăs . to hit, strike; gwơ-dă kwăs kē gnăn shr̉ dŭl, the man hit me on the head with a club. 
kwăs . H. liasua, the itch, or a rish.

kwăt . hunting; tēr kwăt păs, to lie in wait for irame; ŭ-mět kwăt-dă, ŭ-kăt năm-chĕ kā, you went to the hunt, but got nothing.

kwăt . the hemming, at the elges or mouth of a bag, etc.; kwăt por-n jwăl, the hemming at the mouth of the string bag.

kwăt . also, again, too; nyī kwăt kĕ mět, he, too, will go ; ă-pün keūn gnăn kwăt, give me some salt too (or, again), i.e. more; ă-lì sheūk tŏk gnăn kwăt, tell me some more stories (or, speech); kō bāp mă tơng kā, pün kō-chě gnăn kwăt, two are not enough, give me one more, or, another; H. kua or liva.

kwăt . . the brown or black flat horse and cattle tick, which also bites human beings $=\mathrm{H}$. kaskia.

kwēm . H. gyaga, wooing, courting; măt kwēm, a girl who longs for a particular youth; ăntŏk kwēm kwăn-lă d̆̀, I speak the langruage of a wooer that I may obtain (lit. seize, i.e. marry) her; nyī pŏ kwěm kĕ-n mănzăp, he is seeking a bride.

kwēp . the hoof, of all hoofed animals except that of the hor'se, which is dè, or dè shì.

kwèr . the reed buck $=H$. livanta rafi.

kwi . . pitch dark, absolutely dark. See rāp.

kwim . a partiidge.

kwin . . to prevent an entry, as of a man with a load too large to go through a door; pì-dă kwīn nyì, the place prevented his going through, i.e. it was too narrow.

kwīp . . see fŭng kwip, under fŭng.

kwip . the Jukons or Kwororofa; also the name for Wase Rock. The Angass say their ancestol's were true Jukons, and that they seceded 
from the Jukon Empire owing to internal dissensions. After wandering about seeking a new abode, chiefly in the neighbourhood of what is now Dugrui, though one or two parties went ats far as Bornu, the original home whence the Jukons migrated, they collected gradually in their present territory, each party as it arrived forming a separate clan of the Angass tribe. The people they found there were culled Rim, whose descendants are still to be found in the hamlet of Mirr, above Bălm, though the far larger portion of them left the country to the new comers and went west on to the plateau proper. Possibly they may be the ancestor's of Rem, south of Bukuru.

kwit . . small, narrow, as of a goat, or doorway; yĕm

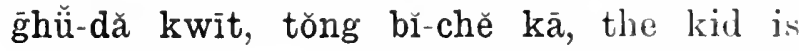
tiny, it's no use for any thing; pó lŭ-dă kwit, the doorway is very small.

kwit . a sound, a noise; fwăn kwit, the rumbling of thunder in the distance.

kwōdì . a snail's (chwīs) shell ; nǐn kwōdì, or chwīs = the snail itself; ăn-pŭs kwōdì, ăn-kyăk, I shot, or threw, up the snail's shell, and caught it = a game like 'knuckle bones'; the shell is also used, fixed on a stick, by old women, to guard their small gardens; any violation of this charm brings on earache.

kwork . a dance during the lot weather, in which men, boys, and a few girls all join; arms are put romul the neighbour's' waists, and all hold more or less together; there is no instrumental music, only singing, generally preceded by the periodical dry weather 
"lrinks'; it is also the name given to wrestling $=$ H. kolina ; at mors-lün, the king and the 'gerkwa' lear off the wrestling, the king always winning; they are followed by anyone who wishes; women and girls, however, do not join in; kăng kwǒk, to wrestle; tŭ kwŏk, a game in which men and boys pursue and catch each other and have a rough and tumble, a strenuous form of 'touch last'; probably this kwork is connected with the following.

kwŏk . . to collect, bring together; mă kwŏk shăk kĕshĕk kă yīl, the whole town has collected together ; ă-mĕt, ă-kwǒk kĕ mă, kŭ tŏk kĕt kĕt, go, and collect them, and talk over the matter thoroughly.

kwǒk . . to gallop; gwŏ-dă kwŏk brüng dŭng, the man is galloping his horse a lot.

kwŏk . . to drive away; ă-kwŏk ghü̆, drive away the goat.

kwŏl . . a male snake, H. lirokia; female known as gwŏn pyē.

kwŏlăm . a tree with red fruit, used in tanning. kwŏlm . H. lirira, to do smith's work; gŏ-kwŏlm, a blacksmith; mwăt kwŏlm, to beat out by forging.

kwŏlm . a lie; tŏk tŏk kwŏlm dŭng, he lies atrociously; chăn $\mathrm{kwŏlm}=\mathrm{H}$. yanlie liaria, to cut, i.e. tell, a lie; kwŏlm bĕ=lit. the lie has come back, i.e. it's no use telling lies, you are exposed.

kwŏm . ground nuts, H.A.= P.A. lănkăn.

kwŏm . . a sort of porch in which the king sits for coolness; a very private apartment; attached only to a secluded portion of a king's apartments. 
kworm . . in pǒ-kworm; H.A. = por-kwăng, P.A. = the leader of a line, i.e. the one who gives the direction of travel; also the one of a line of men, on whom the others align themselves = al 'marker' in military parlance.

kwŏm . . wind; grass matting $=H$. acena ; a low rectangular thatched hut $=\mathrm{H}$. adcald ; an ear; a leaf, whether of a tree, or a blade of grass, or of guinea corn, etc.; kwŏm pǒ sŭ, lit. the wind is running, i.e. it is windy; gwớ-lŏng nyĭ kām kā, kwō (kō) nyí lŭ kworm, mă sĭt dĭ kěsheuk kā, the king is not well, (so that) he is in the porch, where no one ever enters; pi kwŏm dăng gưrm mă fwǒt shě̌k dí, through their ear's men hear speech; mă kĭrp kărm kă kē lŭ, bē kwom, when the 'zana' mat is put in place on the roof of a house, it is called 'kwom'; kworm tē. mă pǒ gyı̆p kě shwē, when the leaves fall it is the harvest time; kworm dūr, deaf; kwǒm dìt dèl kō wărn, pī nē rìt, fwǒt shĕuk tǒk lēlē, small ears are better than big ones, for they are nicer to look at, and they hear more quickly; kwom fwăn, rain accompanied by a high wind; kwŏm fwăn-dă chěn, the storm has cut, or, passed off ; kworm fwăn-dă chěn lŭ-dă, the storm has cut, or taken, off the top of the house; kwom is used particularly for the If:ırmattan wind; kwǒm pŭt, teüng-mă fì kěshěuk. pi kě jĭ wǒng. dăng tăng, when the (Harmattan) winl comes, all the trees dry up, when the world becomes warm, then they spront angin.

kworng . . sicle, lirection; kwǒng sār, the finger's : kworng shï, the toes. See kwăng. 
kwop. an emphatic particle used with fi, to dry up; bì-dă fì kwŏ-kwōp tăng, the thing lıas shrivellel up to nothing.

kwop . . a spear, and a spear being the insignia of a king. it also means authority, sovereignty; dăp dăm kwŏp, he took the staff of a spear, i.e. soveleignty = he became kingr; gŏ kě sĕ kwŏp kĕ păn yĭl kăbūt, the man who has the insignia holds the whole country.

kwŏp . . to sow; tār kwŏp, the sowing season.

kwŏp . . an illness due to the spleen (lăp), an enlarged spleen $=$ H. livorian chililii.

kwŏp . . a dead man's effects; bī kwŏp (icl.); lŭ kwŏp do dă, this is the house where the effects are stored for disposal.

kwŏp . . anything dried or become hard, as leather toucherl by the fire.

kwŏp thin ; gwŏ-dă kwŏp kwŏp, the man is thin.

kwŏp

kwŏs . a small plant, whose fibres are used by girls to make anklets.

kwŏs . the first weeding and clearing of the farm after planting $=\mathrm{H}$. noman fair .

kyăk . H. chab(b)e, to catch, e.g. as of a thing thrown up into the air, like our cricket ball, etc.

kyăng . . to pierce, stab.

lă . to take; mē lă ğhā, lit. what takes you? i.e. what business is it of yours? lăğhā kĕnì kā, you have nothing to do with it; to accept; ăn-lă brüng kā, I will not accept a horse ; to aid; ă-lă kĕnı̆, help him; ă-lă nyi, take it; ăn-lă è-kĕnı̆, I took his 'yes,' i.e. I approved his act, I agreed with him; ăn-lă hầ-kĕnĭ, I took his 'no,'i.e. I refused him ; 
lă shi, lit. to take the feet, or foot print, i.e. to follow, either as in hunting, or as in 'to follow a king,' i.e. recognise and obey him; mŭ lă shî-kění, we follow him; to marry, of a man; kè lă nyi = he took, i.e. he married her ; rìb-nĭ mă lă bě mă lā ? Is this girl takeable, i.e. marriageable? kě küt $=$ she is (marriageable, see yeük); lă kē, to take the head of a thing, i.e. to take heed to; lă kè kā, to ignore, abandon; lă kē kě kărăng-kěni kā, he has ignored, or abandoned, his family; nyì là dí, he it was who brought him-said (in anger) of any one who has guided a stranger to a town; Nèn sǒk ă-lăngăn o ó $\bar{o}$, a call to Něn for rescue, on reaching the confines of another tribe, where the victim (e.\%. going to be sold) knows his own people's will or local god has no influence.

là . a pronoun used only by a woman to or of a woman when for iny reason, such as ignorance or modesty, she does not want to name the woman; pee is used by a man to or of a woman in similar circumstinces; ăn-torng dr lā-nĭ, or lā-dă, or lā-pănă-nĭ, I (f.) will stop with her (understood); ăn-tŏng dĩ pē-nı̆, or pē-dă, or pē-pănă-nı̆, I (m.) will stop with her; kābē dì là-dă, perhaps it's with her (spoken by a woman).

lăb . . to watch, look ifter, care for' ă-lăb nyī kăk, look after it carefully; jěb-mă mă lăb nŭngdă-mă, the boys are tending the cattle.

lăb . . to pierce = II. sokcl : lăb às, he penetrated his teeth, he pierced with his teetl.

lăb worng . the name of the Tuwan tribe, who were in the country before the advent of the Angiss. 


\section{ANGASS MANUAL}

and who now form a village following $\mathrm{K}$ : bir. The majority of the original people, however, refused to remain under the Angass, and went to Garram, and thence to Chip, and some perhaps also to T'shendam.

là-dà . the word used by one woman in calling another; lā-dă, y̆ jì $\mathrm{O}$ woman come along (said by a woman); a man would call out pē-dă yí jī, when for any reason he does not wish to name her. See under là.

lādā . H. ainun, extremely, exceedingly (?) ; ă-děndĕn lādā, you are extremely avaricious.

lā-dăk . . the odd stone over, in the game of dăk, after putting the proper number in each compartment.

lăğhı̌t . . the wrist.

lăk or lěok wal; to make war, to fight; to quarrel violently; ăs lěǒk, a savage watchdog; brüng lěŏk, a vicious horse.

lām. . . to hide, to disappear, to be lost; to sink; lām kĕ nün ăm, he disappeared into the water, i.e. he dived into the water; lām lām mŭn, he disappeared from us, i.e. he was lost to us ; pì tōn-kěnì lām, on account of its weight it sank.

lăm. . to twist strands round each other to form string or rope; to twist, e.g. by rubbing strands of fibre with the palm of the hand along the thigh, to twist them into one string.

lămwăt . a toad; mwĕn mwĕn kā, kĕ dăm kō lămwăt, he can't go properly, he hops like a toad. See lěmwăt.

lāng . to swim; tăm lāng ăm, the boat floats on the water ; ă-măn lāng kè ăm ã ? can you swim? gwŏ-dă măn lāng kĕ ăm dŭng, kĕ 
tē bè dèl, the man can swim very well, if he falls (into the water), he can get across.

lăng . H.A. to lose, be unable to find.

läng . . to hang, hang down; läng fătăt, to hang, i.e. to put on, clothes; nyī lăng sheّ k, he hanged himself : ă-lăng kĕ yōm-dă, hang it to the raifter; kă-lăng-lăng, lhanging down; to stoop down, as in hoeing; bět lăng, to swing; ă-yē sŏng liss-dă à-mět bět lăng, ă-yē mĕs bĕ tăp, catch hold of a tamarind branch and go and swing, if you catch hold of a 'dorua' it will break.

lăng . . to proceed by leaps, as a horse in galloping ; to mount a horse; lăng brüng, he mounted the horse: there being no stirrups, a man has to give several tentative little jumps till the final successful one, and probably the hor'se has been moving all the time.

lä̉ng or to meditate; lěăng chōr, to take counsel; lěăng ă-lěăng bŭt ghā, take heed for yourself; to remember'; ghā pǒ lěăng kĕ sheūk tǒk-dā ? = do you remember the conversation? (or, discussion).

lä̉ng or to deny; to refuse=H. musu; ăn-năng kă pō, lěăng bĕ lä̆ng dŭng, I asked him, but he denied strenuously.

lăngzŭm . the purifying washing of a man who has killed a inan (not in murder), for the groor of the tribe, as in war, or to obtain his skull for a

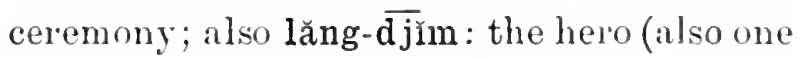
who kills a lion or leopard) is entitled, at the public feasts, to wear a weath of măs leaves on his forehead, and round his arms and ankles, so that all may know of his prowess.

lănkăn . the ground nut $=\mathrm{H}$. gerlda.

lăp . . the spleen. S'ee kwǒp. 
in word used by the Angass to denote tribes other than themselves, and generally it has a derogatory meaning; almost equivalent to - outsiclers' or' even 'barbarians'; kărăngmă năng păk gŭrm-mă tě lăp-mă, the Angrass call the rest of mankind 'outsider's.'

lăp, lěp . to send; gwơ-lăp, a messenger; lăp lěp, to send to.

lăp, lěp . to push in, as a stick into a hole. See preceding.

lăp . . . to polish, smooth; smear; ă-lăp lŭ gnăn shr̆ lèzú , polish (or smear) my house with the earth of an ant-hill.

lăp . . . to answer; ăn-lěp-lěp nyī, bě lăp dăng shěuk büs gnăn, I sent to him, but his answer was impertinent.

lăp . . to look for, investigate, search, scan; ă-mět lăp, go and search; lăp (or nē) kĕ pi, to scan the horizon (or the landscape); $\breve{\text { u-lăp }}$ ny̌̀ à kăt, kè rōt kāa, don't stare at him like that, he doesn't like it.

lăp lăp . the ascending of a flame; lăp lăp kĕ wŭs, a conflagration.

lăs or lěs . the smaller grain store (see yēr, and sŏn-gwŏlŏng); it belongs to the head of the house, and is not touched till there is a scarcity in the other stores; a sort of reserve store. See lěs.

lăs . . the elbow; kwăm lăs, the elbow joint. See kwăng.

lăs . a particle used with pām when the latter is meant to be insulting; lör, is used in sime way.

lăshı̆m . . a malodorous panther $=$ H. tuntur. lăt . . to lie flat, or close, as a piece of mud thrown against a wall to which it sticks, or of a vicious hor'se's ear's. 
lāa . . probably derived from Hausa laya, a charm; only known among the Plitin Angass; there :ue fou kinds connected with tāu, viz: dēm, pǒ-shěuk, rērī, and sinn tŭng; they are all lefensive species of mascots; their whole iclea is an importation from other tribes.

lāu. . the winged white ants, which, as they emerge from the nest, are captured by birls; H.A. = tăpíp P.A.

lăuăr . a prepared stick for stirring, cleaning, or scraping up remains, in a pot of food; it ser'ves the purposes of our cooking spoons. to force, to compel, to cause to do, to place $=$ II. $s \imath$; ăn-lè ğhā kwă-chrn, I will force you to do it; ă-lě nyì (kō) nyı̃ mět, make him go ; lě $\mathrm{kworm}=$ place the ear, i.e. pay attention.

lě . . to beget, to give birth; birth; kă-pi-dōn mă lě-ñgăn (or kă-pì-dōn lě-fănă), ăn-nē kō kō nyì kà, since I was born (lit. since they bore me), (or, since niy birth), I have not seen its like; gwo-lè-lè = an aboriginal inhabitant, or, one born in the country (see gwǒ-jĭ-jĭ, under jü); lě kě lě, travail in childbirth.

lě . . sick, sickness, pain; lě lě dŭng, to give birth is painful; lě po (idiomatic) = difficult.

lě . . to pour (out); ăn-lě yin dǒng kă kè, I poured out the medicine drop by drop.

lě . . used to indicate continuous action; lè mět lè mèt, he was going, going; lě ji lě jì he is coming, coming; lè tā lè tā, he is refusing and refusing.

lě . to wander, to lose one's way; düm kin ká, lě kă-lè-lè, he is not going straight, he is zigzaggring; lè kè àr, he wandered from the road. 
lè

to pass or gro round; ă-lě kă-lě-lě, or ă-lè kă kŭng kă kŭng (latter is II.A.) = go round by another way-said to a man who, for instance, is about to cross a rifle range when firing is taking place.

lě . . to postpone, to cause a postponement; lèngăn, ăn-mět kā, it postpones me, I do not go, i.e. I postpone my deparrture; mănă ă-lẻ kworm $($ idiom $)=$ don't be late.

lë-bwonn . lit. H. haifua-r labewa, the fruit of the edible calabash.

lëdến . filth; to retch, at something disgusting; nē-fā lědèn dŭng, the sight of you is disgusting.

lě ěăk . . to become pregnant, to conceive.

le ght . . the forearm, where the ght, or armlets, are placed.

lèlē . . quickly, hurriedly.

lělĕb or open space; gwǒ-mǐs-kěnĭ pŭt kā-lělĕb, her lëblěb mate (or husband) came out into the open; or lěb it might also mean he came out suddenly, unexpectedly; also lĕlěp, ji lělĕp mŭn, he came on us unawares, or suddenly.

lĕm. . a species of 'kŭm' or household god, a piece of iron, used by two men only, in each of the towns of Kabir, Dawaki, Tabulun, and Chikkan.

lém. . . H. nomi and farin ridi, coriander seed.

lèm. . the sun (in Tabshin, Goshendushe, and Tabulun).

lèmchěnā . a swallow, swift, or martin; lëmchěnā ke yük lŭ-kĕnı̆ wǒk, the swallow makes its nest on a house.

lěm sār . a wristlet, bracelet.

lěmwăt . a frog; perhaps more correctly, a toad. See lămwăt.

lën . . fine, thin, as flour; soft, of a road. 
lěn . . a mat of any kind.

lěǒk . fight. See lăk.

lēp. . to feed; nìn lëp yerm, the mother feeds the child; ninn lepp, the feed mother, i.e. the leading beast of a herd, of goats, or cattle, etc.

lěp or lěb to send, place, to put on, of clothes; lëb fătăt,

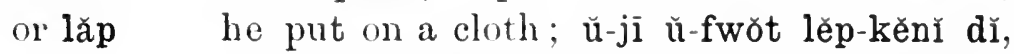
come and hear his sending, i.e. his message.

lë-păn . . lit. to give birth to keep, i.e. one's children alive; măt-dă lĕ-păn kā, the womin canmot keep her children (they all die).

lèp-sār . the palm of the hand.

lèp-shì. . the sole of the foot.

lēr. . H. pa, a smooth more or less flat rock, on which corn, etc., is spread out to dry; mătdă lêr, or lēr pê, saill of a woman, who from some malformation cannot be penetratel.

lěs or lăs . the grain store of the head of the house; its contents are only used during the wet season, towards the end of the year, when the other grain stores are running short.

lēt . . to melt, smelt; ă-lēt bè ă-lēt kō ny̆ nŭng, if you melt it, melt it so that it is ripe, i.e. fit to eat (or drink); see dong; to scorch; wŭs lēt kă lē(t) lēt, the fire has scorcherl it all along (see bēm).

le⿳亠二口犬s . see lìs.

lēzü . an ant-hill ; the earth of which it is made is used as a glaze for polishing the walls of houses.

lĭ . . saliva, mucus $=H \cdot$. mycu, ă-běs lir, spit out the secretion.

lí . . to cut, as of gratss with a sickle; nyī por lí kě shĭt kě pěl shĭt, he is cutting grass with a sickle. 
11-n gwà , the eight lines cut on each cheek of some Beri Beri people.

lí . . to say, sperık; sometimes lě ; ābē mă lì tě gwö-chě müt, perhalps they sặ some one is llearl; ă-lĭ nyì or ă-lè nyī, say to him (that); lè nyĭ lǒk = cut it short, of a narrative.

lì . . welcome =H. maraba; lì-dăk lì-dăk, kept on being said to a new comer till he comes close enough to sit lown and talk; là lì, to welcome; ă-lă lì nyĭ (gnăn), welcome him (for me).

lĭlǐs . . a suffix used with găk, one, meaning 'only'; găk lǐlǐs, only one; găk is itself used with the other numerals in the same way-kwān găk, only three.

lintā or userl by a speaker at the opening of an address lintwā when acting as interpreter $=$ lì tě $\bar{a}=$ 'he says that $\bar{a}$ ' (the $\bar{a}$ to arrest attention) $=$ 'listen to him, O'; ăn-linntwā, (listen to what) I say, O.

lir . . very thin membrane, as the inner membrane of an egg. See fūp.

lïr . . a mud bed raised two feet or so off the ground, and hollow underneath.

lìs or leūs the tongue; līs wǔs, a flame; lìs wŭs yē kwom teung, the flames have caught the leaves of the tree; ăn-fwŏt leüs - ğhā kā, I don't understand your tongue; leüs kĕ tōn shě k, kĕ pŭt (n)pŏ ghā kă, the sentence is difficult, I cannot translate it.

lìs or lüs . the tamarind tree; H. tsamia.

lǐs . . . elastic, bendable but not breakable.

lisār . . a bit (of a hor'se's bridle).

lit . . H. liurumi, a thicket, of the deity only; an ordinar'y thicket is pĩ djŭl kŭk, or pì(-ň̀) kō līt. 
lit . . the cut tribal marks of any sort, on the face; lit-n-găng, the Yergum tribal marks.

lök . . to plait, as a string marle of finer strings; also of the hair =H. lics:o; ăn-lök pó-bwin, I plaited a waistbelt.

lők . . small ; fwør løk, a small stream; g g-løk, a small man, i.e. a boy (dwarf = gwo-dit); secondary meaning, to be near doing a thing; kĕ lok müt, he is nearly dead; ăn-chĭn lơk lǒk ny̆̃. I very nearly did it; nün lě-kènı̌ kĕ lǒk müt, in his illness he nearly died.

lơktĭlǐ . . a cloud.

löm. . soft, pliable, like leather, or cloth; mă gŭrng, bě těp, kō-lōm bě těp kā, if it is bent, it will break, a pliable one will not break; ă-kăt lōm à ? do you find it soft? lōm bwǒk bwǒk, yes, very.

lōm. . thin, thinness, of the body; lōm rit nē kā, emaciation is not good to look at; lom kyăng kyăng, excessively thin ; măt-dă lōm pi lex, the woman is thin on account of sickness.

lŏng . goods, possessions, wealth ; gwǒ-löng =1I. maidulica, a man of wealth, also, a king; löng shì, footed possessions, i.e. domesticaterl animals; the pl. long-mă is generally only used for cattle, and no other form of wealth, though it is sometimes applied to cotton when spun into threatl: lơng bì kĕ găk kā, the goods are not one man's, i.e. they are to be shared.

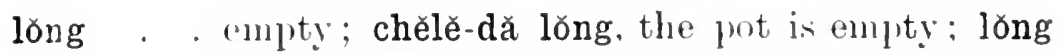
chělè, an emptý pot.

lơng sẽ an idlom, meaning that there is nu hindrance net to the appointment of al king.

lōr. . see lăs. 
lör . . a slug.

lòt . . in dàng lōt = the calf of the leg.

lù . . a singrle hut; home; lŭ-bì, the house or home of it thing (i.e. snake, fox, ete.), i.e. its hole; also a receptacle; lù shwē, the crop of a bird; gwŏ-lŭ, the owner of a house, and also $=$ H. mai-ungua, or chief of a suburb, or outlying village.

lŭk or lïk to throw away; bì-n sār-dă ă-lŭk, throw away what's in your hand; brüng lŭk nyī, the horse threw him away, i.e. he fell from his hor'se; to tbrow, to shoot; mă lŭk wŭs, they threw the fire, i.e. they set fire to, incendiarily; to liscard, to place carelessly. See chār.

lum. . to turn over the edge, as of a cloth in hemming.

lün. . H. rani, the dry season.

lŭnấp . . the armpit.

lŭng . . to scald; ăm wŏng lŭng sār gnăn, the hot water scalded the hand to me, i.e. my hand; or perhaps the actual meaning is, the hot water scalded to me the hand.

lŭng . (Takkas) to swim = bĭndū.

lŭnkŭs. . a tree, with edible fruit $=$ H. kutkuki.

lŭs . . to close up, as of a crack in a wall; lŏktřlĭ lŭs $\mathrm{p} \overline{\mathrm{i}}$, the cloud, i.e. the mist, has shut out the world; to stick, as with gum.

lüs . . see lìs.

lüt . . to be crowded together, as men, children, sheep, etc., all lying down together huddled up.

lūt or lüt. H. goiyo, the infant carried on the back, in a skin.

lwēt . used only of the stretching capacity of rubber; dōn dằng lwè(ē-èt), l'ubber stretches extra-. orclinarily. 
mă . . " preposition, of ; used where kĕ, which also means 'with,' would be ambiguous. See Grammar.

mă or mwă they, them ; -mă, as a suffix to nomns and pronouns, forms the plural; e.g. nŭng, a cow ; nŭng-mă, cows; nŭng-n̆, this cow; nŭng-nĭ-mă, these cows'; măt-nĭ-dă, thiss particular woman; măt-n̆ -dă-mă, these particular women; nŭng-fănă, my cow ; nŭng-fănă-mă, my cows, ete.; mă is also used like the French 'on', but with a much wider range; it translates practically all our passive forms; mă mwăt gnăn=they (or, people, or, one) beat me, i.e. I was beaten.

mā . . a sheep.

măkē̄n . the peeling off of the skin at the root and sides of the nails.

māl . a sister; māl lǒk, a younger sister.

mālā . a string bag; also, a leather bag.

mălăng . a female lizard, the $m$. =gwǒ kĕ nĕt; the lizard in general is gwó-jō.

mălăng . baldness of the centre of the head, from the forehead backwards.

mălm . . a star'; mălm kĕ shī, a shooting star’ also mělm and mwělm; mălm b̆̀t kē kĕ nēr, pī băng, when the morning star is overhead, it is dawn.

mălǒk . . a food grain = H. banliam. In H.A. = māyĕr.

mălong . H.A., a guinea corn similar to H. liaura; sometimes pronounced nălŏng.

mălū . . a fiancée; mă pŏ kār kĕ mălū-fā, they are tampering with your fiancée, i.e. you are a goorl for nothing fellow, you can't even look after your fiancée.

măn or the negative imperative = don't, let not; măn măntă mă sŭ, don't let them, or, let them not, run 
away; sometimes used with kat at the end of the sontence, and also with kā; e.g. măn, (1', măntă, mă sŭ kăt, or', măn, or, măntă, mă sŭ kā, lou't let them r'un away; măn ŭ-y̌̆t kō nyī bār, don't let him escape.

măn . . to know, understand; hence, to be able; ănmăn těnè ğhā $\overline{\mathrm{dj}} \overline{\mathrm{j}}$ gnèt, I know you are a complete fool; brüng măn kē kě jwăl, the horse is able to climh the hill, lit. = knows the climbing of the hill; hence, too, to be accustomed to, but generally turned idiomatically; kě chǐn shĭt-chĭn kō kĕ măn nyĭ dĭ, he is accustomed to work.

mănēr . . a prop, pillar, of a house.

măng . . clear, clean; bĭt măng, the day has dawned =

1I. yai ya uaye; fwăn măng, the rain has cleared off; probably from the following. See ser.

măng . to take up, carry, lift; H. raulia; secondary meaning, to take up a matter, to answer; ă-măng küm, to take up, or answer, in turu the chor'us, or the words of the chief singer, gwŏ-măng-küm (H. alliya), who addresses in his song each person present in tur'n; ă-măng = answer, said to a man in court to tell his version of the story after the other side has been heard; măng sheurk, to commit an offence, the iclea being, to take it on oneself; ă-măng shēūk, ă-măng bissǒk-ğhā, lă gwŏ-chĕ kā, you have lone wrong, you must repent, not another, i.e. you and not another must take the consequence; măng mwir, to skim off, or rather scoop off, with the two hands, the oil floating on top of a lecoction of oil; kě ji măng, next year ; kĕ jĭ măng ăn-chĭn ď̆, I will do it next year. 
măngŭn . a food grain of the H.A., rather litrger than, and similiar to, the II. hattre:

mānzăp . (a ver'y slight $n$ ), a briłle: mă(t) mánzăp kĕ rit dŭng kē, the bride is very handsome; also applied to a girl risitor, i.e. a potential bride. The bride's answer to the above compliment is, gnăn rit dăğhē? am I heantiful indeed? Though zăp hass not been met with, perhaps mānzăp is derived from măt-n-zăp.

mār . . to fiur'm ; a fium ; mā-mār=mār-mār, the recluplicated for'm; mă mā-măr, they were harrl il work farming; shăl mār mŭ tăp shăl mār kā = let's not pick incl choose fimming tools (any bit of iron (loes); bŭt mār, lit. the belly firms or plonghs, i.e. gripes =a severe stomach ache.

mărăn . the mistress of a house, i.e. the farourite wife. generally the first one.

marrin . the sharlow of animate moring objects, supposed to be the essence of life, if not the life itself ; lě-dă lě dŭng, mărin lām, the illness is a very severe one, (his) shadow hats clisappeared. See rin.

măs or mầs the H. doruc tree; a food is obtained from it. măsănă the iron for striking sparks to get fire (lerived from H. marabi,?); the stone used with it is called ğhk măsănă and ğhk pĕr : there are two kinds of stone, but neither is a flint.

măsănă . the white body louse $=$ H. lailinatta .

măt see mwăt.

măt . If. matu, wife, a woman who hats masried. eren if she has become a willow; a willow, if the fact is to be dwelt on, is măt kè miss kā; măt kwèm=a woman courted; măt 
mìs. a ginl no long̨el a virgin ; măt kē, alio nisol for a wirlow.

mat . to milk a silent signial; māt sär, he heckoned, (1) signalleel with his hanel.

māyèr . 11.A. for mălǒk, the foor grilin.

măzăr- a recition (the top one only, ?) of a guinea yăng colns stalk between two knots, used for winding thread on for jĭjŭ, and other purposes.

măzō . 11. fُure; a sort of porridge made into balls. mē? . sometimes mi ? for emphony = what? = H. mi? pì mè? or, chĭn mē ? = why? what for? ŭ-ğhür mēe or, ŭ-ğhür mě-chĕ mē ? what have you looted?

mè . . at the commencement of a sentence, used with dăng at the end=unless; ăn-mĕt kā, mē gnăn kām dăng, I will not go, unless I am well; măn ă-mět, mẽ ă-rōt dăng, don't go unless you wish; ăn-rōt lěŏk kā, mē ăn-kăt fŭng lěŏk dăng, I don't want to fight unless I get a cause to.

mèp . the death limentation, after the death dance mwăk.

mēr . acid, sour, vinegary; wēr dŏng kĕt kĕt, kō mĕ-mēr, the gruel has gone bad and sour.

měs . see mä̀s.

mēs . pith, of guinea corn stalks, grass, etc.

mĕt ol to $g=\mathrm{H}$. tafiji mwěn nearly always used as mwĕn the verbal noun; mwĕn-dă lĕ por dŭng, the going is difficult; mwěn sit, to go trading.

$\mathrm{mī}$ ? . see mē ?

mi . . . to rouse, to get up; ă-mí m(w)ă, arouse them; mă mì, they have got up (as from sleep); kăfwŏn jī mī kǒkorr kĕ sēm, the hare came and roused the fox from sleep.

mì . . . a brother, used as a term of endearment; mì mŭ-nă dó nyī, he is my dear brother; f.= 
yĕm nŭ-nă dō nyì găk, lit. she is the onlý daughter of my mother (so firr as I am concerned), i.e. she is my farromite sister.

mı̆-ğh'à . thine, yours; from mă and ğhā=mă-ğh'à or m̌̀-ğh'à.

mil . . . a very coarse grass $=$ H. yamba, used for making ' rana' mats.

mì mì . . One at a time; ă-dăp mī mī, take them up one at a time, or, one by one.

min . alive; but used in the sense 'still alive' i.e. not yet deal; used of animals, men, trees, etc., which one has thought to be clead.

$\min$. . umipe, raw-of meat; moleveloper, gibberish, or the efforts of a beginner in a language; năm-dă min, the meat is raw; kŭn kā, lĕ min, it is not grown up, it is undereloper; sheuk-tŏk-dă min, the speech is unintelligible; sōt kĕ sě mīn, witchcraft eats raw meat, i.e. kills and eats live men; măn ă-chĕt min kăt, don't cook it raw, i.e. underdone.

mĭ-nă . . mine; ăn-chĭn mĭ-nă del mŭ-ḡhā shĭ rìt, I have done mine better than yours; compounded with the prep. mă and the personal pronoun gnăn, i.e. mă-gnăn = mă-năn, mă-nă, or mĭ-nă.

mĭ-nı̆ . . an euphonic form of bĕ-nı̆=here; ă-jĭ mŭ-nı̆, come here; nyı̆ mĭ-nŭ, he is here; mĭ-nĭ and b bĕ-nŭ, used indifferently; in ă-jí ·bĕ-nŭ, and ă-jí mĭ-nĭ, the accent is on jŭ.

mĭ-nyı̆. . his, the separable pers. pronoun; brüng mínyĭ, the holse is his; mŭn mí-ny̆. we are his, or, its-often usenl when talking of the leath of some one which has just taken place = 'well! we are all his,' i.e. Deatl's, especially of death from smallpox. Com- 
formuled from mă = preep. 'of,' : ind nyĩ = him ; mă-nyĭ. becomes mï-nyĩ = of him, or, his.

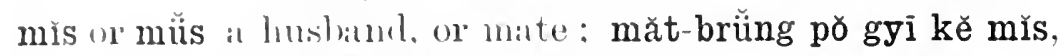
the mate is recking a mate. H. miji.

mis. . the sheil butter tree= H. liadamya; food, oil, and hird lime are olstained from it; mwìr mìs, sìea buttel'; dōn mis, the rubber or' :ilp : ă-gyŏng ă-bēm gnăn, gnăn găng mīs à? you throw at me, who am a fruit of the shea butter trce? (pioverb).

mis kam . lit. great man, i.e. one of the elclers of the village; mĭs-kām fïr, the four elder's, i.e. those who form the tribal council, with the king. In the surrounding dialects, Sura, etc., it is the word for the king himself. See dĕskām or' dìs-kām.

mó. . H. yagara, to be too much for'; of a man, to be obstreperous; gŭrm-ní mō pī, ŭ-kăng kē kă kē, this man is truculent, collect youlselves, i.e. set about him in force; shĭtchĭn-nı̆ mõ gnăn, this work is too much for me.

mŏfi . to sniff up, as a smell; to blow the nose, in native fashion.

mŏghāa . see mwŏğhā.

mōl, in H.A. for a bay pony with black points.

\section{dā mōl}

mōr .

a fool griain = H. yero.

mōr . to suck; yěm pār pŏ mōr kĕ wŭr, the infant is sucking the breast.

mŏs . a fermented liquor made from grain =H. gia, and nearly = our beer'; the name of the mŏs in its various stages of manufacture is-(1) dĕn, after the first forment; (2) boiled again the next day, it is called fwil; (3) next day fermented and cooled, $\overline{d j u m}$, when it is first 
fit to llink; (4) next day nŭng or 'ripe,' when it is at its best; (5) next liny kūn; (6) the day after, chèlng, when it becomes acid and is very intoxicating, and is only drunk by the elder men; (7) the day after, wēn, which most men refuse to drink, as disagreeing with them. The solid portion, after the liquid is drained off, is called shǐshăk and bwok-djĭdjŭ, and is eaten by the women and children only, and has no intoxicating effect; said to have a listinctly sweet flavour and is much appreciated; wăm mŏs or mors wăm= the beer gone bull; even so, it is still llumk by a few.

mŏs-dŭng . lit. plenty of beer = a feast.

mors-lūn . the festivil held when all the cor'n his been harvested and garnered.

mŏs tār . the festival at the commencement of the harvest, about 15th October in Ampier (depending on the tār or moon), and four weeks later at Kabir, which is some 800 feet higher up than the majority of the Ampier farms.

mơt dūr a festivity anıl dance during mŏs-tār.

\section{or măt dūr}

mŭ. . the verbal form of the per's. pronomn ' we,' used with all tenses. In the 'continuous tense,' which is formed with the preposition 'kè,' or the more illionatic: 'pó,' it is of course mŭn; mŭ mĕt, we go, will go, went; let uss go.

mŭk . to sip = H. liniba; rather different from mwăk. mŭk . to plessis, squeere; mŭk gwŏngworn, to throttle; mǔk gwǒngwơn nyĭ, chǒk kābē mūt, lıe throttled him so that he nearly dienl.

mŭlk . . or mwălk, a blister canserl by heat. 
mŭ-mă . theirs, sep. poss. pronoun, from mă= of and $m \ddot{a}=$ them = mă-mă or mŭ-mă.

mŭn . . we, us, to us, for us, used (1) by itself, (*2) as the object of a verb or preposition, (3) before a preposition, (4) subject to our verb 'to be,' understood, in Angass; e.g. mŭn kě rōt, we with wishing = we wish; ă-pün mŭn, give us; wĕ kĕ mět è ? who will go? Ans. mŭn = we; mŭn $\mathrm{kām}=$ we are well.

mŭn . H. tuo; made in two operations. First in one pot witel is boiled, flom of sorts is added and stirred till thick; it is then poured ont into calabashes, and over all is added a little of any one of the oils that are used for food ; this is the first half of the dish, and is known as gwim=H. gaya, and is eaten with relish. To this, however, is frequently adiled pŭk, the H. mia, which is made as follows:- To boiling water add $\overline{\operatorname{dj}} \overline{\mathrm{dj}} \overline{\mathrm{a}} \mathrm{m}$ (H. darlowa), salt, pepper, if required, ground up leaves of the baobab (tōrī), and meat, if available. After well cooking, take out the meat and lay on one sile. The water is now small in quantity; add more ground-up baobab leaves (kwǒm tōri) and mix with the gwim. The combination is mŭn. The meat is eaten first, and then the mŭn; chĕt mŭn, or tŭng mŭn $=$ to cook, or prepare mŭn.

mŭ-nù . . our's ; from mă and nū =mă-nū or mŭ-nū. mūr . . fat $=$ H. lìssi; also mwūr; pŏ-mwūr, a scar. müs . see mǐs.

müs . . the house cat, H. mussa.

mūt . . to die, H. mułu; kwămtăk mūt, so and so has lied; mūt mūt, to be ter'or struck, or frightened to death ; gwŏ-dă mūt mūt dŭng, 
the man is in a pitiable state of fright; leath; mūt yrl = the death of the country, i.e. calamity brought on the country by witehes; also used as a name for a witch or' a wizald ; mūt y̆l păs kěnĭ kĕ yē gwŏchè kā, the arrows of a witch hurt no onesaid as a shout to a crowel surrounding, to calpture, a witch, to encomrage them.

mūt-lüng . an abusive wort applied to personal deformities; kūm mūt-lŭng, an enlirged protruling navel. See wŏdlön.

mŭ-wŭ - yours (pl.); from mă and wū $=$ mă-wū or mŭ-wŭ.

mwăk . . to scrape the flour dregs, etc, of a dish, with the crooked forefinger' and licking it off.

mwăk . the death dance round a man's corpse, especially the king's; tăm mwăk, to dance the death dance. See mēp.

mwăk or to sip, to take a little at a time, as of a liquid mwork too thick to drink; to lap-of a dog, ete.; a little; tŏng mwăk, he waited a little.

mwăk . . in yĕm mwăk = a grass used as dress by women instear of leaves.

mwāl . . fat; mă pŭn kō nyř mwāl, they geld it so that it may get fat; H. lilbla ; = myār in H.A.

mwălk . the skin all burnt off by fire, as by one falling into it.

mwălk . the H. dafara tree; its silp is used in making anything sticky, e.g. as a binding ingredient of a sort of cement; also used for 'sticky.'

mwălk . clay, for building houses, pots, etc.

mwălm . slippery, to slip; pi kāp-fănă dăng pī mwälm kĕ gnăn, because of my boot, I slipped (lit. the place slipped with me).

mwălm . a vegetable $=11$. guccus . 
mwăm. . caterpillars and their kin, anything that can climb upwals and eat the leaves of a tree; ('la wling insects.

mwat or to beat or strike.

mwŏt, or măt

mwăt . with tĕng = the trunk of a tree; mwăt teūng kè rit shipp, the trunk of a tree is gool for making a bedstean.

mwè . sap. milky juice; mwè t tüng, sap of a tree; yĭt mwē, tear's; mwē shĕ $k$, pus, of a boil, etc.; mwē kĕ ăm, or, kĕ jwăl, water oozing out of rock; also the slime track of slugs, snails, etc.; chōr yĭt ny̆̌, kō yı̆t mwē tŭm, pity was bitter to him, so that tear's fell, i.e. he pitied lim sincerely and wept.

mwěn . all euphonic for'm of mĕt, or mwět, to go, e.g. mwĕn sǐt, to go trading.

mwir . oil, grease; mwir pēt $=$ 'itii $i$ ' oil.

mwìm . to stalk, prowl, go stealthily; gwŏ-dă po mwìm kĕ năm, the man is stalking game; ăn-mwìm ăn-ğhür bi-fănă-mă kwăn-mĕt, I'll go off stealthily with my goods (said by a woman meaning to leave her husband).

mwŏghă vertigo, dizziness, sunstroke; the hot season or mŏğhā of the year'; sometimes, too, pronounced bŏḡhā; ŭ-pŭt bĭt-n-bĭt kō mŭ mět; tār bŏğhā pūs-kĕnǐ rît kā, go out early in the morning when we start; in the hot season its sun is bad.

mwǒk . . see mwăk.

mwŏl . . a brother'; mwöl-nă, my brother (both whose parents are the same as mine); also a cousin, but the latter is more generally mwŏl yĕm pŭp.

mwŏl-lä . to toboggan. 
mworgi . the Sayawa, neighlbours of the Angass, on the north.

mwot or to beat, strike.

mwăt

mwūr . see mūr.

myăk . (frequently myăk myă̌k) tisty, sweet, well flavoured.

nyâr . the sound emitted by women while pounding col'n.

myār . the pegs of woorl stuck into the walls, on which to hang articles.

myār . IL.A. for myāl, fat.

myār . al grass, H. jeme; it grows near water chiefly; 'faifais' are made of it by the Hausas; but it is used for ornamental armlets by the Angass girls.

myār . . to leap, to ricochet; lūk ğhk bě-nĭ, myār jī tẽ, he threw a stone here, it ricochetted, came and fell.

myār . . to twist a strand of string"; especially used of the strip of skin to be made into a bowstring, so as to get it into a state of torsion. myirm . the python $=\mathrm{H}$. mesa.

nă- . . the f. prefix for names, gó- or gwo being the m. form ; gwǒ-ār (m.), nă-ār (f.); gŏ-fwăn (m.), nă-fwăn (f.), the former meaning one born on the road, the latter one born in the rain.

năğhm . H.A. a malre.

nălbăk . an exclamation in hunting used to notify to the other hunters that "I have hit it!'

nălöng. . a graain foorl, a species of goninea $\operatorname{corn}=\mathrm{H}$. liaura. See mălong.

năm . . meat, flesh; ăm năm, soup. 11. nama. 
nămbă reel coh antelope.

năn

lig. large ; important; brüng năn, a big horse ; 1). năn-mă, or năn năn-mă, the latter being used like the llausa mainya mainya.

năng . to call ; à-năng ny̆̌, cill him ; ă-năng mă, mă ji lëlē, call them to come quickly; mă năng kă kē Bĕrĭ Běrr̆, they called themselves Beri Beri.

năng . . to give; hand over ; ă-dăp yĕm ă-năng nĭn, pick up the child and give it to its mother; mŭ-năng mă mă tă, we gave it to them (also, we called them), they refused.

năng . . to inquiie ; ă-mĕt ă-năng dăng, go and inquire ; ăn-fwŏt kin kā, ŭ-yīt kō gwŏ-chĕ jĭ dĭ dăng, kwăn-năng kĕ pŏ-kĕnı̆, I don't understand properly, let some one else come that I may inquive of him.

năr. . H.A. the 'bante' skin, the skin worn behind; P.A. = běnnĕ (from H. bante); mă băk năr kě shōp, one cuts a tasselled fringe on the edge of the hinder apron.

năr. . on, upon; with the sense, too, of being in the middle; năr kē, on the head, or on the top of ; năr kē kĕ lŭ, on the top of the house ; pŭs kě kē, dār năr, the sun mountss and stops on the top.

nāzā . the guinea col'n=H. farfara; nāzā nyì dō brüng kĕ rōt, 'far'fara' is what a horse likes.

nbwār. see bwār.

nē . . . to see, understand; mŭ nē kā ? don't we see? - said to endorse thoroughly something just heard; used idiomatically; dōn ŭ-nē sh eưkdă-mă kă shī-nă, yesterday you completerl (siw) the discussion in my absence.

nè . . where? See nĭnē. 
nĕ who, which, whom; it is not always inserted, and where it is not used the Hatusa irliom is followed; gŭrm ně kĕ mĕt, kō kě bě, the min who went lias returned; ă-tŭ ghü pŭtöm nĕ pŭt dí, kill the first goat which eomes out; gwŏ-ní nĕ ăn-lăp dōn dōn bě jī, the man whom I sent yesterday, has come back; sometimes mě in H.A.; (kä) pĩ nĕ gnăn pó shĭt chǐn ă-dǒk-dǒk, (at) the platce which (i.e. while) I am working, keep silence.

nëfŭr . . the open space, surrounded by a stone wall, in front of a compound, where councils are held, some cisses tried, etc.; there are similar spaces for dancing; the surrounding wall itself; nēfŭr-ă (ă for dă) băng dŭng, kō pì tăm dō dă, the space is well clealled, like one for dinncing in ; pŭs chěn nēfŭr, $\mathrm{Ol}^{\circ}$ nëfŭr pŭs chĕn, a sum halo, which is tikken as an omen that a king of Ampam has died; nēfŭr tār chĕn = a moon halo.

nēgēr . the back bone, spine.

nēgyin . a a small bean plant, which spreads along the ground, and grives a fibre, pŭs, of which string is made.

nemmerl . the local native word for the Angiss town we call Kabaran.

Nèn . . the creator, Ciod; Něn-kěnĭ kĕ yē ḡhā, may its God seize you, i.e. may retribution overtake you, an expression of anger; Něn nyì kè sơng ān, mŭ chĭ (n) răng ? mŭ lē yǐt nyĭ, kō mŭ nē dăng, it is God who has tmoned it thus, what shall we do? let's calst om eyes to Him, so as to see; bi Nĕn pün nyí = lit. the thing Cod gives him, i.e. his share; bì Nĕn pün ğhā = youl shat'e; gŭrm kěsheūk bě kĕ 
kăt bī Nën pün nyĭ, every man will get his - halr: Něn pơtēung kĕ nē gnăn găk, Goul ahove alone rees me, silil hy a man who has no wituesses. II.A. Nān.

nèn .

spicler; těăng (or tä̀ng) něn or něn těng, : spicler's web; as among the Hausas the spider is supposed to be possessed of extraordinary wile and acumen; něn sĭt wŭjāi nün ăm shĭ nŭng, the spicler pulled the hippopotamus out of the water by craft; nyi kō kŭn-kěnĭ-dă, něn tāl nyı̆, kwō düm lŭk pŏ ăm, mighty though the elephant is, the spider by his wile went and forced him to the water's edge; nĕn pǒ shwē kě lŭ, the spider is spinning his web; kĕ fîs kō tä̀ng něn, your head is marked (or your hair is rubbed off) like a spicler's web (abuse).

nēr. . the midlle; between; kă nēr, in the middle; mălm bìt kē kă nēr pì băng, when the morning star has climbed to the middle (i.e. is high up) the morning dawns.

nět and red; hot, heat; gwŏlŏng nyì kĕ lāng bì nēt nèt găk, only the king puts on (wears) anything red; lěŏk-dă kě nēt dŭng, kō mŭ kăt pì kā, mă chīn mŭn, the fight was very hot, so that we got no advantage, they defeated us ; shĕ̌uk-tŏk-nĭ nět dŭng, this talk is very hot; gwŏ-dă kĕ nĕt nyĭ, the man is making hin angry; gwŏ-dă nĕt dŭng, he is very hot (temper'ed) man; nĕt kwǒk kwŏk, or nět kŏk kŏk, very red, or quite red-applied to a skin, light coloured as a Filani's.

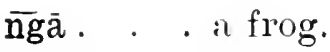

ngăss . . cheek; the name given by the Hausas to the people we now know as the Angass, and the latter, who call themselves Kărăng-mă, 
now call themselves ngăss-mă; ngăss-mă mă chāl băk; the Angassi hive (one) cut on the eheek; ngăss dŭkŭlŭm (dŭgŭlŭn), one without the one-cheek-line of the Angass. See chăl.

ngŭm . . insects in general = 11. liururu.

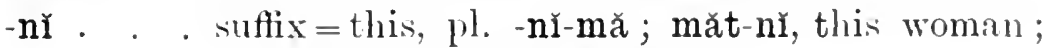
măt-ň̆-mă, these women.

nin . . mother'; nin lēp, the leasler of a herd, lit. the mother feerler; nĭn lěŏk = H. unua yalir, lit. the mother of the army of war, i.e. the general in chief, it also means a multitude gathererl for war; nĭn sōn bì = H. unvar busa, the leader of a musical band; nı̆n sär, the thumb.

nĭnè ? or perliaps a compound for nĭn è? C'f. H. enna? ně ? where? ghā nè ? or ğhā nině ? where are you? mĕt nĕ? whel'e has he gone?

njī . . an animal like a large weasel (?); perhaps a squirrel (?); it inhabits rocks and kills fowls.

njī . . H.A. for a bay horse =H. suri.

$n j \overline{1}$. . a sort of monstrous birth, the infant lluring the day time keeps its natural size, but during the night it assumes the proportions of a full grown man; it is taken to the caves and killed.

nük . any thickenerl liquid, as gruel, beer, etc.; foolish, marl; gwǒ-nĭ nük dŭng kō wēr, this man's wits are thick like gruel; thick of body ; gwǒ-dă mwāl dŭng nük trilì, the man is fat and thick set.

nük . . nearly ripe; mălök nük, the 'bankam' (grain) is nearly ripe.

nük H.A. a bowstring ; nŭk chăn-chăn pār-dă, that ılay’ nŭk, P.A. the bowstringr broke; a phrase used to mean 
that everyone fought resolutely till their strinus luroke, i.e. to the lis.t.

nüm . II.A. to deceive = P.A. dik o o dük.

nŭng . to ripen, to be ripe, to be fit to eat; năm-dă ke nŭng, the ment is cooked sufficiently to eit; nyĭ kŭdì kĕ nŭng kā, it is not yet ripe. 11. munu.

nung . . to burn, to set fire to; wŭs nŭng ăn, the fire burnerl me; ă-nŭng lŭ, set fire to the house; ă-nŭng wŭs, light a fire ; to cook; to sting, of an insect.

nŭng . (probably from nŭng, to be ripe) intelligence, intelligent; cumning, craftiness; yěm pār kŭt nyǐ yūr kō kě nŭng kā, the infant has not arrived at intelligence yet.

nüng . . a cow; nüng kĕ găm bŏng, a cow fills a fold, i.e. by births.

nŭng . . a cleared enclosed space, like a fold; mŭ chĕn nŭng shǐ kěm, we cut, i.e. surrounded or enclosed, the space with cactus.

nŭng . . = nywăng, q.v.

$n v \bar{u} \quad$. a regetable $=H$. risga .

nyăl . to tread on, to crush with the foot, as a scorpion, beetle, etc.; dăp shī, dĕn gnăn, kō nyăl gnăn nyăl gnăn, he took his foot, pressed me down, and crushed me, crushed me (said by a woman describing her illtreatment at the hands of her husband).

nyăng . . on purpose, deliberately; b̆̌-chě kā bǔ-chĕ nyăng nyăng kŭk, it was (or is) nothing but deliberateness.

nyăng . . to beat flat, as floors, etc., H. cleble.

nyăng . . to set fire to heaps of rubbish, e.!. the grass, etc., cleared for farming; to set fire to in many places, as houses in war.

nyĭ. . he, she, it; him, her ; to her, to it; some- 
times nyì, nyĩ mă lă shăk kĕ-n gwơlơng= he is like a king.

nyì. . an elephant; sär nyi, elephant's trunk (lit. hand); nyì kě shwē ăm shĩ pŏ kā, shwè sě sär, an elephant does not drink with its mouth, but with its trunk.

nyı̃n . paucity, loss, failure; ny̆n tōm, a paucity of blood, i.e. fear; nyĭn tōm mwăt gnăn, panic seized me; nyǒk kě nyĭn tōm, to breathe rapidly from fright, includes, too, to have one's hear't in one's mouth; nyĭn ăm, thirst; nyĭn ăm tŭ mŭn dŭng, mŭ wŭrn kō mŭ kăt por-fwor, we are exceedingly thirsty, let's hurry and get to the stream.

nyĭn . probably same root as last; hunger'; nyīn mă lě nyĭ, he is hungry, lit. hunger makes (but note the Angass idiomatic pl. 'make') illness or pain to him.

nyĪn . tired out, fatigued ; dr gnăn kě shĭt chĭn-dă, kwăn-nyinn, lit. trouble to'me with the work, so that I am weary, i.e. I am tired out from the work; nyork kě nyìn tōm, a final sigh of relief.

nyir . the vulval.

nyők . to be without; ă-nyơk nŭng, you are without sense; pĩ yĭyĕl, măt-kěnĭ mūt kěsheǔk, lǒk lơkk-nĭ kĕ nyơk măt kõ găk lǐs kā, owing to the epidemic, all his wives died, now he is without even one; to lose; ăn-nyork lorngfănă-dă, I have lost my goods.

nyǒk . . the lungs, breathing; rest; life; nyŏk-kěnı kě düm, his, life is over'; bì-sě-nr torng nyők kě gurrm, this food is sufficient for (i.e. to sustain) al man's lifé; shăng nyǒk, rest; nyők füt, : sigh.

nyơng . . see nywăng. 
nyōt . to gaze, to stare, to stand on tip-toe to look; gwǒ-dă kĕ mwěn bě kĕ nyōt ākŭk, the min is wandering about garing in vain.

nyot . a full helly, one visibly swelled with fool; gwǒ-dă kè nyōt bŭt kō mă těně ghül kā, the man llaws in his belly so that they may say he has not hal enough to eat; porkin nyōt, a protruding forehead (not liked), " ter'm of abuse.

nyōt ur to foul a place.

nyōt nyōt

nyōt . a ver'y small piece, or share; pün gnăn nyōt, he gave me a very small bit.

nyōt . . to strain over heavy work; ăn-bět ğhk ănnyōt kĕ kēe, I pushed at the stone and strained over it.

nyük . . to hump the back, as a cat, or a porcupine.

nywăng . to shoot, to hit, sting, but not used with the first person, i.e. one cannot say, 'I shot him,' but shī nywăng ăn, a bee stung me; also nyŏng and nŭng.

nywĕ . . used for wŭn, 'you,' in a sort of oratio obliqua; for examples, see the stories in the Grammar.

$\overline{0}$. . . often used for kō in all its uses; ă-pün kō rīt (or ō rìt) gnăn, give me a good one; ă-lĭ nyī kō (or ō) nyì mět, tell him to go.

ŏk . . . to dig, e.g. a hole, grave, well, etc. ; mă ok tūn, they have dug a grave = fŏk, q.v.

păk. . some . . others; păk mă mĕt Pĕr, păk mă mĕt Bwir, some went to Ampier, others to Bwir. 
păk. . . H.A. for jŏk or djök, a species of 'juju.'

păk. . to put one thing on top of another'; păk păng. to build up a stone wall.

păk. . the renninder; ă-sě bísě ă-pün păk ăs, eat the food and give the remainder to the dog.

pāl . . (vicinity of Fìr and Tăkkăs), a bed male of strips of the tuliurua palm, hored and threaded together; it serves as a solid mat to sleep on.

păl . . H.A. to stumble, or trip, and fall; also used when a man's argument is inconsistent.

păl . . unripe; fresh sprouts or buds.

pāl . to lie down; H.A.; gwơ-dă lè dŭng kě pāl, the man is very ill, he is lying down.

păl . . . to feel pain (?); măn ă-lă kō-n păl, don't cantie that he should feel pain (?). H.A. (?).

pălăng or to praise, and so, to thank; ăn-pălăng ğhā pălng dŭng, I thank you (originally, I praise you): kă shĩ pălng bĕ ŭ-wẽ, after thanking (me, him) go home.

pām or a flat surface; flat, even ; pām kō jătŭr, Hlist

pām pām like a flea; bǐděr gwŏ-dă pām dūng, a flat r'umped man; pām lăs, an offensive term, meaning the same as the last; also pām lör, id.

pām pār . see under pār, and pār pār.

pān. . . to give; to hand to one = pün; ăn-chār bĭ-dă dŭng, mă dăp pān è? I want the thing̣ badly, will they give it?

păn. . . to drive away; dün lěók gwǒ-m Păng mă păn gwo-m Bwir-mă, in war Ampam thove off Kabir.

păn . . . to keep; ă-păn ăs-fã pi ăs kě gwơ-chě, keêl i clog yourself, on account of the other man's log ; ğhã kě păn dăm, ăs kě ăt ğhã kā, one (lit. you) keeps a stick lest a dog bite one; 
yěm păn nǔn, a child keejs, or sustains, its mother; in H.A., to remember; ḡhā pǒ păn kè shĕuk tǒk-dă? lo you lemember. the talk? = P.A. leăng; llom this word probably is lerived the following :-

păn. . to be like; to take after; yĕm-dă păn kō pŭp dŭ, or, more idiomatically, yěm-dă păn kō mă pŭp dr̆, the child takes after his father.

pănă . rondler, there (distant) ; suffixed, it becomes a demonstrative pronoun; brüng-pănă, that hor'se ovel there; gō-pănă, that man; gōpănă is also used in calling to a man whose name is unknown = Hi! you there.

păng . a poisonous large snake=H. kasa; said to be able to swallow a hare. See under gwom.

păng . . a wall, teriace, etc., made of stones and rocks; also a very large rocky hill or mountain, but the latter meaning is confined to Hill Angass = P.A. jwăl; e.\%. Păng is the local name for Ampam, which we have accepted from the Filani, who corrupted it from gwŏ-n-Păng; again Păng chĕn = a terraced rocky hill where the chĕn or large hoes or spades are made, and this has come to us as Pankshin. Ampam is also called Păng gŭzŭk, to differentiate it from Păng chĕn.

păp . . . a beard ; gwŏ-dă kĕ tŏng bĭ-chĕ kā, bĕ kĕ pŭt păp, the man is of no importance, though he has a beard.

pār . . an infant, baby; yĕm pār, idl.; yĕm mā (n) pār, a suckling lamb.

pār. . night; the night time; also used where we should say 'day,' e.g. I'll see you another' lay; pār-chĕ băn-nē (for bĕ ăn-nē) ğhā dăk ; pār-chĕ dŭ (or mŭ)-n gwŏm=H. sai wata rana, we'll meet another day; pār pūs kĕ 
$\mathrm{ji}$, the day of settlement has come, e.f. of debt, contract, etc.; gwǒ-mǐs pār, a night thief, a hyena; also men gifted with powers above the normal, as with a sort of second sight; a night husband, in a woman's dream; pām pār, euphonic for pār pār, very early in the morning.

părp . to smash, with a noise; the spluttering and crackling of $\log$ in a fire; the crash of thunder'; the splitting of fried nuts, etc.; an explosion.

părp . . to pluck, of grass, forls, etc.; ă-părp fīp kī, pluck the fowl.

pār pār or ver'y early in the morning, while it is still păr-npār dark, but just before dawn.

or pāmpār

păs . . . an arrow; păs tĕn bĩ, a needle.

păs. . H. damana, the wet season. In the Hill Angass and Sura; gŏ-păs as a man's name = the P.A. gŏ-fwăn.

păt . . sheath of a knife; H.A.=P.A. kīp.

part. . the blowing away of anything in the wind.

păt . . buzz of conversation; noisy shouting; wō

(wē) mă păt dō dè? who are making the noise?

păt . . an emphatic particle; ăs shǐ kē păt, the tooth is quite separate.

pătpūl. . an owl with large pointerl eilrs; its hoot three times at the door of a house portends calimity.

pè . . white. See pyē (success).

pē . . to shut, close: ă-pè por chělě, close the mouth of the pot.

pé . . to show, indicate: ă-pè ăs-mă, show it to the dogs, i.e. in hunting, to show the grime to the dogs for the latter to go in pursuit. 
pè . . in the expression ă-pè (or ŭ-pē), kăsăm kă kē, say something favourable about it, almost equivalent to our 'pronounce a blessing'; said when a child is ill and it is taken to its glamparents, in the hope that their blessing and good wishes will effect a cure; probably the same word as pè or pyē, 'white.'

pè . . she, her ; only used by a man (see lă) of a woman whose name is understood, but which for some reason he does not wish to mention, e.g. his own wife; pè nyı̆ mĕt, she, so and so, has gone; ăn-tŏng dì pē-dă, I shall stop at her house.

$\mathrm{p} \overline{\mathrm{C}}$. . . to adilress the Deity ; only three or four recognised men in a community do this on the occisions of the big ceremonies precerling the festivals, etc.; also, to divine, used of the seers who are called in on all occasions when outside arlvice is required; the seer = gŏ-pē; his implements are the dē pè, i.e. the whole shell of the tortoise, and the ghk pè or smooth pebbles used in combination with the dē; gŏ-kŭm kĕ pŭt dār kō pē kŭm-dă dú, the priest has come out and is standing to have an intercourse with the Deity.

pĕl . . a knife for cutting grass, etc., a sickle.

pēp . . H. gadda, the oribi.

pēr . a tendon, a ligament; mă chōt păs shĭ pēr năm, they bind arrows with ligaments.

perr. . the native Angass name for Ampier; gwŏ-m Pĕr - the people of Pĕr-fiom which is derived our Ampier.

pèt. . the itiri tree, from whose fruit, which resembles an olive, but is purple, a valuable 
food oil is obtained ; mwèr pēt, the itiri oil ; mwèr pēt nǘn chělě kă găm găm, in pot quite full of itiri oil.

pēt . . a gelt bull.

pèt . . the numeral five; gurm pēt, five men.

pèt . . all, completely; used of ten with mumerals, e.g. kwān pèt, all three; mă pēt, all of them (also=they are five); yăl pēt, he has gone completely; ă-kăs gnăn, bě ăn-kăs ğhā pēt, if you abuse me, I'll abuse you in retur'n thoroughly; or, if said ts a crowd, it might mean, if you abuse me, I'll abuse you all.

pět . . a broom, to sweep.

pi . . a place, spot; also used impersonally and widely for the world, sky, etc.; pi-wŭs, a fireplace; also the spot where the chief holds his court, trying cases, or discussing matter's; pī-nı̆ tǐp dŭng, ăn-nē kā, this place is very dark, I don't see anything; pi büs, the seat of any fatal wound or illness; děl kè $\mathrm{pi}$, authority, sovereignty $=H$. fiko-n ruri; ăs kè sě $\mathrm{p} \bar{i}$, the dog bites everyone; pi kè bĕl, the sky is clear, used of the Harmattan haze, as well as of rain; pĩ kě chĕn, the sky has cleared, i.e. there is no storm after all; pì dŭr tār =lit. the place of burying the moon, a scene or episode in the festival of mors tār; pi shi, a footprint, spoor ; pi fí, a dry place, also a drought; an opportunity; ăn-kăt pī ăn-pün jělmăt wŭn, if I get an opportunity, I'll give you money; cheưng-ăn, ăn-kăt pi kwăn-mèt kā, he is too much for me, I can't get an opportunity' to go; pi-da, the plice, the place which, where; ăn-lă shì kě pì-dă sŭ kěsheǔk, I will follow wherever he has rum off to; 
(tork) pī tǒk, wlispel'; măn mă tơk pi tǒk pǔtōl, gnăn pǒ rōt kě sēm, don't let then whisper ontside, I wint to sleep; pi bwāp dŭng chrnŭ, the weather ( $p \bar{i})$ is very cold to-day-this is better expressed pi bwāp chinnı dŭng; pī chinnı̀ bwāp dŭng, though it would be understood, is not used by the Angass. It will be noted that $p \bar{i}$ is used impersonally corresponding nearly with our ' everywhere,' 'everything,' 'everyone'; e.g. mŏs kăs kĕ tŭ pī bŭl, the beer made from the kăs grain kills the whole place, i.e. kills everyone who drinks-an idiomatic way of saying it makes everyone drunk, or is very intoxicating.

pì . . On account of, because of ; pi mē ? because of what? why ? jĭ kě d dō pì jūr, he brought a complaint on account of malice; mă pün zīn gŭrm pì rōt kădăk, one does not necessarily believe a man because one likes him; ă-jĭ kā pì mē? why didn't you come?

přl . . an emphatic particle; very; wŭs kĕ pı̆l, the fir'e is mounting very much, i.e. high; năm-dă pŭt pĭl, the game has got out (and we didn't see it go); heary accent on the prll.

pĭl . . . sometimes almost pīl = H. tofa, a strong spiky grass, which gives a fibre for string.

pin . . to break, divide; kō pin dè, one who breaks a calabash; chĕlě pin, the pot broke; ă-pin kă-dün, divide it in the middle; ă-pin răn kin, I have drawn a straight line.

pipp . . to burn leaves, grass, etc., at the entrance of a cave or hole, into which something has entered, in order to drive it out or kill it; mŭ pip nyĩ, we burnt him out. 
pīp . . . " particle; nyr tè gnăn pùp, it fell from me, plup.

prp tǐrk . an emphatic qualification; gwo dă gŏ-fwēp pŭp třrk, or pŭk tŭs, the man is mighty fat.

pir . . . to open, to extend, as the wings of a vulture before rising to fly, and in soaring; to open, as a cloth in a market to see if it is good all through.

pirt . . to put out, of a fire; ă-pĭt wŭs, put out the fire; to put on the fire, of a pot; pit kĕ chělě, II. girlien tuliunia, putting a pot on the fire. pít . . H.A. and Sura, to call ; ă-pĭt ny̆́, call hìm; ă-p̌rt gwǒ-n-shī, call so and so (H.A.).

pó . . a mouth, opening; used in many idionatic ways, the most important being in the 'Continuous' Teuse, where it has the same meaning as the preposition 'kě,', 'with'; e.g. in the Hill Angass one may still hear gnăn kě rōt kě ăm, I with want of water (now, yesterday, or ten year's ago), i.e. I am (was, or had been) wanting water. In the Plain Angass por takes the place of the first ker of the two, and the sentence becomes gnăn pǒ rōt kě ăm; ă-wăng pơ-kěnì nyì put; winnow its mouth, that it may come out, i.e. winnow so that its husks come off; mŭ nē mă pŏ kwăng pŏ kwăng, we see them in all directions; pǒ teung, above, sky; tōnkěnǐ pǒ gŭrm kwăn, its weight is that of three men.

pǒdăng . $\log s$ of wool for a fire.

pŏ-fíl . H.A. for goitre= P’.A. pǒ-chǒk.

pōjām the chin; pơjām kè păp rì-rìt, a chin with a beard is a fine thing.

pŏk. . to peel, to klin; ă-pŏk zŭm-kěnŕ, peel off it: skin (lack). 
porkīn. . the foreheal; in front; ă-dèl porkin, pass by to the front.

pőküng . = küng, elge, brink; only used of streams, ponds, etc.

pŏ-mwür a il scill.

pŏnüm . the ğums.

pōr . . to put out in the sun to air or dry.

por. . a very severe itch; also such as is caused by the healing up of blisters caused by fire, etc.

porr. . H.A. a restless, wandering, and so, worthless, fellow. See pŭr.

porr . . to spit, spit out.

pǒs . . to scrape off, rub off, as dirt on the body; smear. See pwăs.

pŏsin . sunset, the west; pŏsin bĕ ă-jŭ, gŭrm mă wẽ shĭt mă jī, come back at sunset, the men return home from the farms then.

pŏteūng . (possibly from por $=$ (the idiomatic use of) mouth, and teüng, a tree, and so, anything above), the sky, filmament; ă-lăb nyı̆ kăk, look after it properly; an answer frequently is, kĕ jāl pŏtěung à ? nē b běnĭ băng, will it fly to the sky? see it is right here.

pŏteưng . smallpox; pơteưng düm gŭrm-mă kết két, smallpox finishes off men very thoroughly; smallpox is also called mūt (bì lě) dē (see dē) ; bĭ lě mē ? what disease is it? Ans. dē, the lord, i.e. smallpox. Smallpox is greatly dreaded, and is personified as a short broadshouldered man with a huge quiver full of arrows. He can be seen by those gifted with second sight; ă-băt yı̆t, ă-ně, bě ă-mĕt, if you open your eyes and see (him) you will go, i.e. die; mwĕn kĕ yĭl-kĕnĭ kŭk, he is merely wandering over his country-said when smallpox is epidemic. 
poteǔs. ( (perhạ sor por třs) the stubble left after the crops are cut close to the ground. See yăng.

portōl . (probarbly from por and tōl, though the latter' has not been met with) outside; măn ă-lŭk fătăt pǒtōl măntă shěuk, don't put the cloth outside lest it become wet.

pó-tür. . a term used as an address between two very great friends; pò-tūr, mă lě-ngăn, nyí kě bèl kè-sheük, my pal, they tell me, it is cleared up, or, the matter is ended. See tūr.

pŭk . H. Inkia, a rough hut made of grans; also used of the better class of grass lut made of matting and thatch.

purk . the cotton cleaned of all seeds and extraneons matter, sometimes used of the plant itself. See pŭtŭk.

pŭk . . to take everything away, to devistate, etc., in war; inchudes the burning and destruction of goods and houses; pŭk mŭn kĕt kět $=$ he has devastated us utterly.

purk . the H. mia, a species of soup. See under mŭn.

pŭk . . a tree $=$ H. dargaza; its bark is used as a food flavouring.

pŭk tŭs . see pĭp tĭrk, ił. pŭl pŭl . a butterfly; also püll püll. pün. . to give.

pŭn. . to geld or castrate; of a woman, to abort; also used of cutting off the combs of cocks; kī pŭn pŭn, a capon; măt-dă pŭn äk, the wom:in has aborted.

pŭp. . father'; used also of any important man of the family, important, that is, by reason of his age, e.g. an uncle; with the possessive pro- 
nouns pŭp becomes contracted to pŭ where necessary for euphony, e.!. pŭ-nā, my father, not pŭp-nă, ctc.

pŭr. . . to burn out, as of clriver ants, by applying hunches of buning grass wherever they are seen; ŭ-š̆t shĭt kū dăp wŭs kū pŭr shăng dr, tear up grass, light it and burn out the ants.

pŭr. . a restless man who does not stop and work with his father, but wander's about; a worthless fellow. See porr.

pŭss. . the sun; the day; puis dŭng, a festival, or festivity; pūs kĕ tăp kẽ, the sun bends its head, i.e. it has passed the meridian, or, it is past noon; pūs yē tār, the sun has seized the moon, said of an eclipse; pār pūs, a fixed day for settlement, of debts, etc.; pūs chĭnĭ-nĭ kē mŭn kě pūs bĭs, idliom, lit. the sun to-day has mounted over us with a bad sun-said when a time of worry or trouble comes.

pŭs . . to shoot, as of an arrow; or of insects, their stings, etc., i.e. to sting; it generally connotes the meaning that the arrow has hit its mark.

pŭs . . . rough string, with not so much care or finish as tắng; the fibre of nēgyı̆n, a species of bean $=$ H. matan kanara.

pŭs . . . to spin=H. liadi. See tăt.

pŭs . . diarrhcea, perhaps a secondary meaning of pŭs, 'to shoot'; bŭt pŭs gnăn, my stomach is very loose, or', I've got diar'rhœa.

pŭt . . . to come out, go forth =H. fitta : pūs pŭt bŭdēr gnët, the sun has come out red, i.e. as at first rising; mŭ măn kě tār kō răng è kō nyì pŭt dì ? do we know how many months 
it is before it comes ont? or is born? - said of a pregrlant woman; Ans. No, we don't;

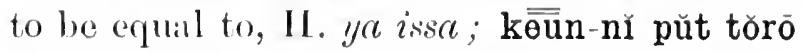
kà, this salt does not come out to threepence, i.e. is not equal to, or enough for, threepence, (töng, however, is better); to happen; mè pŭt è ? what has happened? (see tēr); bī-nĭ nyì pŭt āṅhā, such and such a thing has happened, or, the matter has happened thus.

pŭtōl . see pơtōl.

pŭtom . . the first, foremost; front, before, of time or' place; bwŏt pŭtōm, to put a certain sheepl, etc., in front of the others as a leader.

pŭtŭk. . the cotton plant; and also the cotton itself, which is also called fīm and pŭk; sometimes called pŭp kĕ long, i.e. father of property, as being the original commolity of exchange and barter'; bī pŭtŭk-fā, lit. it is your cotton, i.e. your goods, said, for example, when wrangling over the shares of a dead man's effects, and one claimant eventually gives in and admits another's claim; pŭtŭk, possibly, was the first form of permanent possession among the Angass, of any value for barter purposes. See pŭk.

pwăs or H. shafa, to smear, anoint.

pwis

pwăs . . to shoot, but generally userl of many shootings, as of a flight of arrows.

pwē . used with rŭs, a sneeze, to denote a long drawn-out sneeze.

pwèl . the locil Angass name for Dawaki town.

pwì. . fresh, new; bì-nì jú-n pwì, lit. this thing laus come new, i.e. it is a strange thing, mseen before. 
pwin . a spoon.

pwìs . to leccive; ăn-pwís nyĭ shĭ nŭng (or, shĭ tăl), I deceivel him by cumning (or by a stratilgemi).

pwìs . to anoint. See pwăs.

pwor . . = H. tuo, used in Ampier and its subsidiary towns.

pwor . H. gus ?us, boiling water with oil, salt and flour, well stirred and cooked.

pyāl . . the thigh; generally used of cattle; of man it is usually jwār.

pyăn . . to split, to tear apart; săp kĕ yĕndăl pyăn yōm-dă, the lightning split the tree.

pyār . . to leap, to jump, not upwards but lengthways, especially used of the jump when startled; ăn-kăt mŭlūt tēr kă ār, ăn-pyār ăn-dăm, I came on a leopard lying on the road, and started and leapt.

pyārng . to exchange ; Lănkŭk pyārng kō năn-năn-mă, kō lě kō gyĭn gyĭn, Lankuk exchanged the big ones and replaced little ones.

pyè or pē . white, or perhaps, light coloured; dă pyē, a species of locust $=\mathbf{k u ̆ m}$ köl ; also a white hor'se (H.A.); bī pē pē mă păn pī pūs dŭng, people put on white things at a general gathering.

pyē. . success; good luck; pyē nyï dŭng, lit. success to him plenty, i.e. he obtained in plenty what he was after (idiom); this is a secondary meaning of pyè, white; the opposite. i.e. failure, is expressed by rāp, which means dirt, and darkness; rāp nyì dŭng, he failed; chơk kĕ pyē nĭ, he escaped successfully; kin pyē-ngăn kwăn-kăn (=kăt-n) chĭm, my front was lucky (i.e. I was luckỵ) and I got a lizard. See chĭm. 
pyèn . . to break, of many things, as of egggs; păk mă pyèn, the rest broke; pin is used of one thing, as a stick.

pyèn . . a crack, as in the drying of a mud house, etc.; pyěn kē, a headache; kē pyěn gnăn, mỵ head aches.

răm - is matter of the lighest importance, or interest; importance, dignity; mŭ tŭ bì răm, we have killed a most importint thing, e.y. lion, pig, leopard; Kănchăn dèl gưrnă shì răm, Ampam exceeds the Plain Angass in importance; rīp-dă kĕ răm dŭng, the gill is the pick of the lot, i.e. the beauty queen.

răm . . in phrase ŭ-dār răm, for' heaven's sake, stop! said, for example, when a host of men in their excitement are hurrying off anyhow to a fight, and a chief arrives on the spot and stops them, and gets them into some kind of order.

răn . . stripes, spots, patter'n.

răn . . . to tie, to bind, used generally of a man only; bāt is used of animals; ă-răn nŭng, keep' your wits about you.

răn . . . in dă răn, H.A. for the H. danda, a horse with white forehead and four white stockings.

răng . . to scatter'; mă lẳng kwơp, dăng mă răng, theỵ quirrelled over (denied) the succession, and scattered.

răng . how nuuch? low many? ?how ? ă-nĕ bě răng ? what is your opinion of it? sōn răng è? how far is it?

rāp . . lirt, filth ; rāp kě děn bì-lè, dirt causes sicknesis.

rāp . . larkness; pār kě rāp gǒ-wăt-mă dōm mwěn. 
on a lark night, thieves begin to go about; the larkness of night, as contrasted with the day, whether there is a moon or not (kwi $=$ pitch dark); useel illiomatically to denote firilure, e.\%. rāp nyĭ dŭng, darknesss to him plenty, i.e. he fariled completely. See pyē.

rè . . H. yenta, to tie grass together in flat long strips for thatching, making fences, etc.

rẽ . . to form a line, as for battle, etc.; ă-rē mă kă rē rē kwăn-tăng mă, form them up in a line so that I may count them.

rèm . the present race of Angass on entering the country found a thinly scattered population who called themselves Rem. The majority of the latter retreated before the invader's, and went westward across the plateau; there is now a town south of Bukuru called Rim, which possibly may be the home of the emigrant Rem. A few Rem remained behind, and their descendants are now at Mīr above Bălm.

rērì. . an animal of the weasel tribe. rēs . . a bamboo; jăng rēs, a bamboo bow; mă găt (mă) chĕt lŭ kĕ rēs kă găntăng wărn găk, they make (or, are in the habit of making) the roof of the big porch only of bamboos.

rĭm . . see rĕm.

rīm . . see kŭrbăng.

rīn . . the shadow of inanimate objects, see mărin; ă-yāl kă rĩn kwă-tŏng kă pŭs kădăk ? (proverb), will you get out of the shade and sit in the sum, i.e. will you leave the good and go to the evil? rīn teững-nĭ, pūs kĕ kē kădün, măn wŭ-tŏng dì kā, don't stop in the shade of this tree at noon (because it is a resort of the jiggwěl). 
ripp. a marriageable virgin, also used of a girl, who, though she has misconducted herself, is not married ; this last, however, is practically unknown; yěm-măt kě tơng rīp, the (little) girl has become marriageable; rip dūn, a deflowered girl ; rīp bưdër dür, $o r^{\circ}$ rīp küt kè kē, virrgo intarta; pl. rěb-mă, which is an exception to the plural rule, for it should be rip-mă, though the latter is occasionally nsed, especially in Ampam.

rip . . the itch, H. licaliai; it also $=$ the other Hatusil word licitici, chisff of beaten gritin, e.g. rip shwē, rīp gŭzŭk.

rīp . . chaff, husks; ă-fī rīp ă-fō, dry the chaff and throw it away; pi rip, a threshing-floor'; măt mă pŭt kă pĩ rīp, bě kēpăng gnăn kă düm, the women have gone to the threshing place, but I am too ashamed to go there (for fear of being jeered at).

rrp . . to turn a thing over, so as to set it in its proper position, e.g. a pot which has fallen over.

rìp or rĭb . to divide; ă-rīb shwē nün băndār kă dün dün, divide the corn in the basket into two equal parts (lit. in the middle); cf. H. rabbla.

rĭp . . a mar'sh, or swamp.

rìt . . good, beautiful, well; rī rìt, for rit rit, :11 emphatic form; = H. lien; rit-n yit, goorl to the eyes, i.e. gool to look at.

rŏk . . to throw or cistst down, as in wrestling; brüngdă rŏk gwo-ăa, the hor'se threw the man (the rider).

rōt. . to like, love, wish, want; a wish, pleasure; rōt tŭ(gn) ăn, pleasure kills me = I $\mathrm{nm}$ delighted, a colloquial exagger:ation; the negative forms of rōt are used to lenote 
'lyy lolce,' P.y. ă-ắng kè rōt-fà kā, you will pay with not your liking, or wish, i.e. you. will be forced to pary.

rù . . to reach, atrive, to be sufficient; ă-rū kĕ mă kă yŭl-dă, alıive with them, i.e. guicle them, to the town (or comntry); sĭt-dă rū, the bargaining is sufficient, i.e. satisfactory. ruat or the crown bird, H. goralia.

rwāt rüm . the white flower's of the Rimi or silk cotton tree; they are used as a flavouring in cooking.

rŭm . . making balls of flour, and throwing them into the mouth, H. hamizuda.

rūm . . to sprain, to tur'n a joint; ăn-rūm kwŏk shī, I have sprained my ankle.

rŭrŭ . . shouting in the bush, war-cry, etc.; a complaint; cf. H. kururua, a war shout, probably from the Angass kĕ rŭrŭ, with a shout; mă jŭ kĕ rŭrŭ, they came with a shout, or shouting. Probably the original word is rŭ, and rŭrŭ is a reduplicated form of it.

rŭs . . to bend double, to bend down so as almost, but not quite, to break, as in bending back long grass to get it out of one's face, etc.; ă-rŭs shr̆t, break back the grass; rŭs kăng kĕ chŏk, a man with no neck, his head in between his shouller's; zŭm rŭs kŭn, humpbacked.

rŭs . . a sneeze; pwë rŭs, a long drawn out sneeze; rŭs pwē kĕ lŏk wŏk nyĭ, if he sneezes, he is on the road to recovery (rŭs in an illness is a good sign). 
săk. . to weave, H. salia; mŭ săk fătăt kō mŭ sĩt keun, let's weave a cloth anl buy silt (with it).

săk. . to cut down- of trees, to cleill bush liand for a far'm ; săk mār; to cut; ă-săk shǐ-n küp, cut it with at swoml; săk sák, ol să săk, to keep on cutting; $\because \%$ H. setsiscrlice, to carpenter.

săk . . to shilve; cf. H. aslict.

sāl. . a tree, whose bark gives a fibre from which string is milde.

săl . . H.A. for an open space $=$ H. yili.

săl. . to brew; săl mơs, to brew drink; mă săl mors shr shwē, they brew beer from guinea corn.

săm . . to sharpen; ă-săm kō nyĩ ās, sharpen it so that it gets an edge.

sẩng . . in lŭ sâ̄ng, a porch, shelter from the sun.

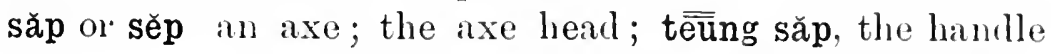
of the axe; săp zăng, an olnimmented axe.

săr. . the arm from the shoulder, inchuling the hand; the haind alone; sār pŭt gnăn, iny hand went forth-said when a man means he has done something, as a murder, accidentally, i.e. he had no control over his hand; mŭ mwět kō mŭ yē sār-mă kă pi müt, let's go and shake hainds at the deceatsed's house, i.e. condole; ŭ-tē sār, yěmmăt, clill your hainds, you girils; zŭm săr, the back of the hand; lẹp or lèb sār, the back of the haml ; dün or din sarr, the palm of the hand; kăng kě sār, the wrist; kwǒk sār, the wrist lone; jẹp sār, the finger's; nin sār, the thumb; fir werr, the forefinger

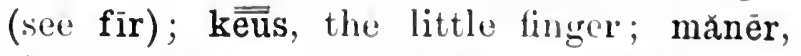
the second and thind fingers together; sār 
sè. the eating hand, i.e. the right hand; sār kül, the left hand; sār gǔzŭk, a handful, i.r. a small shuaf, of gŭzŭk; kwŏng sār, the fingers.

sār. . tenn.

sě

to alt; bŭ sĕ $=11$. allin-r $\cdot 7 h i=$ food; sĕ yŭl, to ant earth, i.e. to salute, to pay homage; mă sĕ nyī, they lave eaten him, i.e. he has been convicted; sār sĕ. pronounced sā sĕ, the enting hand, i... the light hand.

sēm . .leep, to sleep; kĭrp yĭt kĕ sěm, he closerl his eyes and slept; nyin sēm, to be sleepy, sleepiness.

sèt . H.A. to go = P.A. mĕt.

seum . a cough.

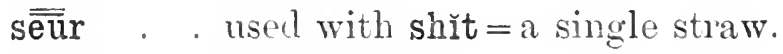

shăk . striin, filter.

shăk . used with the numerals, e.g. shăk fïr, four times. See shì.

shăk . together; each other; with the preposition kĕ, with, it forms the reciprocal pronoun; mŭn pŏ tē kĕ shăk dăng gwŏ-nĭ gyŏng-ăng shı̆ chŭk, we were falling together when this man stabbed me with a knife; mŭn pŏ shĕuk tǒiz kě shăk, we are talking with each other ; tār mă kě pūs mă kăng shăk kā, the moon and sun do not join each other, do not meet; shr̆ shăk, against one another; ŭ-dār shĭ shăk, lean against one another.

shām . H.A. for, to alight, come down. See shĭm.

shām . . to die out, of a fire; wŭs shām, the fire has (lied out (pĭt = to put out, a firee).

shăng . . the remainder'; mŭ sĕ, dăng ǩŭdĭ shăng dĭ, we have eaten, but there is still some left; shăng-kĕnı, what is left, lit. its remainder.

shăng . H. aliuda, to move a little, to shift, to make 
loom for; ă-shăng kō nyí tǒng dí, n1iıke room so that he maly sit here.

shăng . . « net; gwǒ-dă kĕ mět kĕ shăng fworr mět pyē nyi dŭng, the man went to the river with a net, and was most, sucecessful; shăng sār = : net hanclbag; shăng yerrp, a liugge net used for callyiug ehaucoal.

shăng . to stretch oneself, as affer sleeping, or getting up) from is crimped position to stretch; shăng sār, to pull out the fingres's, so that they erack; ă-shăng kō mă kăng kă yìs, keep it stretcherl so that one may join the bones together-sinil to a mill who has broken his legr, so that the broken ends may not overlap.

shăng . . to call out one man from a crowl; mă shăng gō găk kō nyĭ pŭt dĭ, they cilled to one man to conie out.

shăng . . to glean; shăng shwē, il.

shăng . H.A. for the driver ant:

shăng . . enjoyment, pleasure; shăng gnăn kā, it is no pleasure to me; shăng myăk myăk, very tasty; brüng-dă shăng sŭ-kĕnı̆, the horse is pleasant to ridle; shĭp shăng torng kā, the bed is not pleisant, or comfortable, to sit on; pŏ shăng shĕ̌k ḡhā, you are enjoying yourself ; yit shăng. pleasint to the eyes; shăng nē kĕ pī, pleasant looking on the world, i.e. a pleasing landscape.

shăng gĭr " ganne in which a ring is made to enclose one gìr of the players (children), who then tries to make his way ont, but is stopped by the ring. at the threatened point, alosing "1p' together to prevent him.

shăng

a gime or amusement of youngsters, chiefly shăng ginls, who hold one foot by the opposite 
hand and hop on the other'; also squatting almost on the heels, and catching hold of both ankles, and then hopping like birds on both feet together; the latter is also called chōt chōt.

shăng shì a game in which the chilhren sit in a line with their feet stretched out before them; a grown-up ummarriel girl then goes and cracks all their toes by pulling them; if a toe does not respond, she says to the owner' yı̆-măn gwŏ-mǐs-mă, you have 'known' husbands, which, from the absurdity of itthe children all being small - is greeted with shrieks of laughter. (The Angass girls to not mary till they are seventeen or over.)

shāshā. . s’̣philis, derived from the Hausa ; only known through the slaves who have returned from their Hausa or Filani master's.

shēr . . a friend; mŭ tŏng shēr kĕ mă mŭ mwěn kŭk, we are friends with them, we go and come, lit. we go simply.

shĕt . quiet, silent; lām shět, he hid close; wŭn shĕt d̆́, be quiet, will you! măn ă-fwǒt gnăn shĕt, don't think silence of me, i.e. clon't think I'm doing nothing, if you don't hear news of me; ă-tŏng shĕt, sit still. See dǒk.

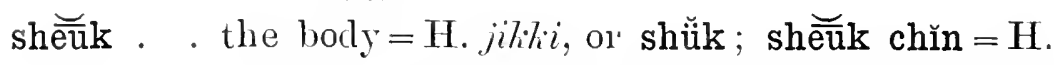
halli, one's nature or disposition; chǐn kĕ kwăt shĕ k chĭn kĕ gŭrm, hunting is man's nature; jĕb-mă shĕ k chin kĕ Nĕn, children are a blessing from God; br sheu k, by oneself; ăn-mĕt bi shĕ̌uk, I went by myself ; nyĭ chun bi shě̃uk, he did it by himself; shape; shěuk-kĕnĭ răng ẽ ? what is its 
shape? (also, more idlionatically, mă lă

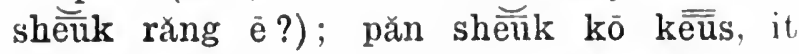
takes the shape of a carrien's luad parl, i.e. it is round.

shĕk . talk, speech, discussion; genemally used with tǒk, e.g. sheuk tor $=11$. maıяance.

sheuk . . wet, H. jillili; nung sheuk, not yet thoroughly ripe; bì-dă tẽ ăm kō sheūk, the thing fell into the water and has got wet; of iron, 'bwāp' is used for 'wet.'

sheuk . . is used for the pers. pronom when the latter'

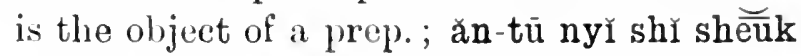
(not shı̆ nyı̆), I killerl him with it; jĕlmăt kè gwā-mă mă tăng sìt shì shěuk, the cowries of the trader's, one comnts (i.e. does) trade with them.

$\operatorname{sh} \breve{\mathrm{euk}}$

măng

a crime, an offence; sheǔk măng bī rōt kădăk ; ă-chĭn bĕ ă-tăp, clime is not of one's own liking; if you commit it, it's your own affilir; măng shĕk, to commit a crime.

shì . . the prep. with, becomes for euphony sĭ, and sĕ; mă yē bŭp shr shăng, they catch fish with a net; wơng kĕ chën shĭ chổn, l)odo cuts it with his nails (so the men tell the women regarding circumeision); shř kē, lit. with hearl=different, separate, it is generally reduplicaterl, shř kē shř kē; with kē, head, and the possessive pronomn, it forms the reflexive pronouns, e.!/ gnăn shr̉ kē-fănă, I mỳself; nyī shr̆ kē-kěnı̆, he (she, it) liinsulf (hes'self, itself).

shr. . a flý, a bee; shr kè lè äm, the bee pous's ont, or makes, honey; shĭ kě nyŏng ḡhā, düm müt, the bee stings you, finishes and dies.

shī . . Wağes, hire; chĭn shìt gnăn, ăn-äng shī ḡhā, do work for me, and I'll give you wages. 
shì. . with the ordinals forms the adverbial numerals; shī bāp, twice; shī pēt, five times, see shăk. 'This shì is probably the same as the shi meaning 'foot'; cf. H. sau, a foot, and sau bin, sau hudu, twice, four times.

shì . . H.A. for kwămtăk, so and so.

shì . . a foot; yìt shì, and kwŏm shì, the inner ankle bone; lěp or lěb shī, the upper surface of the foot; dün shī, the sole; băng shī, the heel; pǒ kworm kě shī, the inner and outer edges of the foot; pèr shì, the tendon Achilles; kă shì, aftel'; kworng shī, a toe.

shǐbă . . the stones or beans, etc., with which the game dăk is played; H. yayan clarra.

shĭdĭdĭ . (generally reduplicated) gradually, bit by bit, one thing at a time; ă-lĭ bĭdēr kě sheũuk-dă ng-ăn (for -dă gnăn) shĭdĭdĭ shǐdǐdĭ kō nyı̆ düm, tell me the origin of the matter bit by bit to the end.

shǐkãr . . a hook, or projection built on the walls of huts to hang things from, to prevent rats getting at them; ă-dăp ěs shĭkār kō ŭ-chět mŭn d̆̀, take the hanging corn (or the corn from the prop) and cook mŭn with it. See kār.

shĭm . . a skin, either tanned or not; yěl shĭm, to skin; fis shim, to prepare a skin, ehiefly by taking the hair off, and with plenty of washing and soaking and beating with ashes; leather; it is shown as evidence of a theft of a goat, etc., and so comes to mean evidence in general; ă-kĭrp shĭm kĕ kē gnăn, cover my head with the skin, bring the evidence against me; ă-kĭrp shĭm kĕ kē-nā, covel' me up with a skin (note the dative gnăn in the former sentence, and the pers. pronoun -nā in the latter). 
shĭm . to descend, come down. See shăm.

shim . ashes of guinea corn stalks; usel as a flavouring in food instend of silt.

shrng . . a mortall, male of a hollowed ont section of a tree, for pounding corn.

ship . the couch, or bed, cut in one piece from it tree; it has four short logs, and is slightly hollowed out. See tām.

shisshak . the solid portion, or the lregs, i.e. the resiclue of corn, in the brew of beer; it is eaten by women and ehilden, and is not intoxicating.

shĭt . to teach; ăn-shǐt ḡhă kō ă-măn chǐn-kěnĭ dĭ, I will teach you that you may know its doing, i.e. how to do it.

shĭt . jungle, bush, grass; chĭn shĭt, work in gereral, especially farm work; ŭ-chĭn shĭt rī-rït ŭkăt bărăng kā, do your work thoroughly, so as not to get (into) trouble.

shōr or a foleskin; pǒ shōr, uncircumcised.

shwōr

shwăl . to stretch, stretch out; ă-shwăl sār kō ă-lă, stretch out your liand and take it.

shwăl . to annoy, trouble; ă-shwăl kwŏm gnăn dŭng, you amnoy me (my eal's) very much (I won't listen to you any more).

shwār . . to laugh. See jŭk.

shwăt . . to pluck up, of glass, guinear corn, etc.

shwăt . a cleansing ceremony of one who, in error, when not entitled to eat any of the offeringsis to the gods, has so eaten.

shwăt . . to extract, to pluck up, of grass, etc.; shwăt pün nyl̆, he has taken it out and given to him, i.e. he has abolicated the kingship in his favour; also used for , to drive a man ol woman out of the family for mislects. See tit. 
shwē . to weave; shwē-n jwăl, to weave a bag. shwè . H. sha, to lrink; shwè shăng, to feel pleasure; shwè shí bit, lit. to llink with the holn, to cup (the operation); shwē ăm (kō) mūt, to be drownel; shwē-p̌, to chew, of tobacco, etc.; shwē-n tül, to smoke a pipe in the ordinary way.

shwè . guinea coln; bāt shwè, a tied up bundle of gruinea coln; sometimes used of all the tall standing crops in general, e.g. (H. gero) mwōr.

sim . . a hleam; dün sēm ăn-nē sīm, in my sleep I had (saw) a dream; mă sēm dăng, kō mă nẽ sìm dăng, only in sleep is a dream seen. See sūn.

$\sin$. . to toss up, as a dish with grains in it, so that the bottom grains in turn come to the top; to stir a pot of food, so that the bottom portions come to the top and are replaced by the upper ones.

sin . root of trees, grasses, teeth, etc.

$\sin$. . . with pūs = the time nearing sunset.

sīr . . . an oath; ăn-fwŏt shĕūk-dă kā, mă sīr găk, I don't understand the matter, let them swear' together'; ă-mět ă-sīr pŏ Kŭm, go and swear by Kum.

sir . . one who refuses to do what he is told, lazy (but especially the former meaning); mă lăb nyı̆ tě mĕt, bĕ tā băng, bě sīr sīr dŭng, they sent him to go, but he declined and absolutely refused.

sīr . . repentance, regret; ă-măng shĕuk tŏk kā dŭng, bĕ ă-mět ă-sīr nyī, if you have committed no great offence, go to him, anl say you are sorry.

sǐt . . . to enter, go or come in, pass bỹ. 
sĭt . . to bangain; buying, or selling; sit mŭ mwěn, mŭ kăt kā, we went out to tracle, but got none. sít. . to pull up, as of grass; to extract, as a splinter, or something in the eye.

sìt . . Ciluse to rise, or get ont: bì słt mă Bornō, nyī

sĭt mă Kŭrpăng, that which ciused them to leave, or get ont of, Borno, the sinne cansen them to leave Kurpang-an incident in the history of the Angass; possibly this should be derived from sĭt to come in, thus, that which entered them (here) from Borno, the same entered them from Kurpang.

sĭt . . to tike out, or off ; ă-sĭt fătăt, take off your clothes; à-sĭt lŭ, bring it ont of the house (also, entel the house); lě-kĕnir sít gnăn, its pain takes me out of myself, i.e. is intolerable.

sǒk . . to hide.

sōl . . . to sew, to thread beals; ă-chŏk ă-söl, gather' them together and thread them.

sōl . . the will cat.

sōm, . ¿ hlor'n; sōm bì tē shř-kè, horns for blowing are of difierent kinds.

sōmpăl . a hornet.

sōn . . far', tall ; sōn răng è ? how far?

sŏng . H. :alali, a food made only of certain edible leaves and water, a sort of soup : it contains no flour or silt or any other ingredient.

sŏng . to change, transform, H. samya; to be metilmorphosed, II. rilikila; bi sorng sŏng, at thing to wonter at, as anything unseen before; chèn yōm-dă sŏng gŭrm, cut the woxl and turn it into a man, i.r. a statue or iolol; to exchange; to say one thing one lisy and another the next.

sóng . a branch of a tree. 
sōt . . witchicraft ; kăt! sōt kĕ răn wă, I say! witchcraft has male its pattern!-said when a sull is found with the small perforated holes in it associated with witcheraft.

sú . . to run; kworm sŭ, the wind puns, i.e. it is windy.

sǔk. . a rore; sŭk pi, an eruption of sores, as in smallpox.

süm . to chew; but more especially to crunch, of laad grain, etc.; pün lănkăn gnăn ăn-süm, give me a ground-nut to chew.

süm . a name; süm kĕ pr̆-nı̆, Pwĕl, the name of this place is Pwel; süm-ğhà tě mē? or süm-ḡhā răng è ? what is your name? H. suna.

sün. . a dream. See sim.

sŭn . . to dry up, of pools, streams, etc.; ăm-nı̆ kĕ sün kā, this water never dries up.

süp . . . to wash, of the body only in P.A.; to wash in general, in H.A.; sūp kē, to wash, i.e. clean and anoint, the head, that is the skull obtained fresh for any festival ; sūp kwŏp, the investiture of a ling, with all his insignia; he commences naked, is anointed, washed, and given the rarious articles of clothing and regalia; kŭ mět mŭ sūp, let's gro and wash.

sŭr . . a tree $=$ H. mairtie.

sür . . father-in-law, son-in-law; măt sürr, motheror daughter-in-law; c $f$. H. surlit.

sür . . dew; sürr-(d)ă kē n-yùl dăng tăng, the dew rises from the ground, and makes all the grass wet, or fresh, or green.

sürr. . to take on the appearance of age-of goods only ; chělè-dă sür, the pot has got old.

sür . . gratin a year old or more, so long as it is good. 
sūr . . to fry.

sür. . to keep' a gool lieint, titke conrage; a-sūr ă-tŏng dăk, take courage and rematin firm, sail as condolence to one who hiss lost, e.?., his father.

sürr shwè . H. zangmmia, the top joint of the guineat coln stalk containing the head.

sūwà . a general name, or surname, given to all males of Kabir, till they are old enough to have an indivirlual name; suwa is the name of a place in louguri, through which Kabir. passed in its nigration before reaching the present settlement; similarly all Kabir females are called chălím.

tā . . to refuse, H. lii ; kì tā tēr kă kē, the hen refuses to sit on top (of her eggs); ăn-tā mĕt, I refuse to go; tā gwŏ-dă, she refuses her husband, i.e. she has left him, and has gone to her father who approaches the husband and tells him, the latter's answer is, ăn-tā ny̆ băng, 'I, too, refuse her', and the divorce is complete; to warn; mă tă b̆́-dă ğhä, they warned (hindered) you of this.

tà . . to stop at a place, on the road, e.g. if two men are tiavelling, one, seeing a house of a relative, may say to the other', ăn-tà běni dăng, I an going in here for a little time (I'll follow you later').

tà . . to ooze out liop by drop, a drop; ăm pó tā, the water is coming out by drops.

tā . H.A. to be full, of a river' ăm-dă tā fworr dung, the water fills the river from bank to bank. 
tā . fol tĕ ă-; mă lì tā jĭ, for mă lì tĕ ă-jĭ, they say, viz. come = you ale to come. See tè.

tābā . tohacco; probably taken from the Hausas, as tŭbō is the H.A. wor'l ; shwē tābā, to smoke tobacco; gŏ-kŭn nyĭ kě shwē n-tābā pŏ, zăng kĕ shwē-kění n-tūl, an olıl man may chew tobacco, but a young one smokes it in a pipe.

tăbirt . the fruit of the bĭt tree $(\mathrm{H}$. liaro) ; it is cooker and eaten.

tăbok . iboru (H.), flour wetted anıl pounderl in a mortar, and made up into balls.

tăbŭr . the brains.

tăknă . . or mole idiomatically, kĕ tăknă, a very emphatic particle, by no means, by any means, whatevel'; kĕ chĭn kwăt è ? kě chĭn bǐ-chě kĕ tăknă, nyĭ mwĕn shĭt-mă găk, what can he llo now? He (i.e. he is allowed to do) can do nothing whatever except wander in the bush: tŏng ny̆ kĕ tăknă, nyı̆ mĕt kwăt, it by no means snflices for him, he will go again.

tăl . . to pluck fruit.

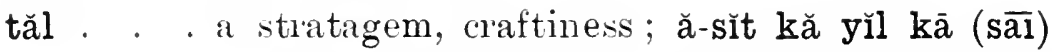
shĭ tăl dăng, you will not enter the country except by stratagem.

tāl . . to munch, masticate; ăn-tāl bĕ ăn-tāl kā, I munch but I don't munch, i.e. it hurts me to munch, or, I can't munch properly, or, it is ' unmunchable.'

tālā . (probably a compound word), to relieve; used especially to relieve a friend, who is carrying a load, of his load, so as to give him a rest.

tālāmŭn . H. nyengnyauc, a beast that lives in holes, and makes great raids on ground-nut and 
other farms, and can kill al dog ; a species of fox (?)

tălit . adultery; gŏ-tălit (in.), măt tălit (f.), an adulter'e'; gwǒ-dă chín tălit, chín br-chě kě tăknă, gyì măt, the man has committel adultery, he can do nothing now, but has become (like) a woman, i.e. he hats lost all his religious rights of sacrifice and participation in the ceremonies, etc.

tām . . a tall bed or conch mate, together with its four legs, in one piece by carving it out of it tree; only lings latve tām, in the P.A., other's have the lower, and generally small, ship; but in the H.A. tằm is not confined to the chiefs only. In the P.A. the tām is placed in the por kwom, a porch behind the house; another is platcel in the large hut where cises are tried, and the king sits on it throughout the hearing; the word is also used for a boat, there being no boats in the Angass country, but they are seen at Wase.

tăm . to dance, st:ımp; shiver, thrill; mă tăm keumm kó mă lè keüm, they dance and sing; ăntăm kě rōt kĕ nē-fă, I dance, or thrill, at the pleasure of seeing you.

tăm . a pit for game to fall in.

tăm . morning; po tăm pī, early morning before sunlise.

tâmì . this year = H. lyanna.

tăn . . to shiver with cold, w fear; ăn-nē nȳi, wơk gnăn, ăn-tăn, I silw it, it frighthteneil me, and I shuidereul.

tăn . . H.A. to push a man over in joke or accirlentally so ats to callse him to fall = P.A. barăk. See tèn. 
tăn or tèn tho "madairlie' tree, the local mahougany. tăng yomug shoots, hersh leaves, a sprout; yrm mă tàng, töng gyin, the larres are green and fiesh, and tit to wear (by a woman).

tăng . . to count, tăng bāp bāp, count by twos, i.e. 2, $4,6,8$, ctc.

tång . corn grown in too wet a spot; it grows up, but loes not ripen.

tăng or to increase in numbers: ḡhü kĕ gwó-dă mă tăng tăng dŭng, the man's goat has increased (lis numbers) a lot (by births); probably the same root as tăng, to count.

tăng . H. ashe! an exclamation; tăng! kwămtāk mūt, I say! so and so is dead.

tăng . a sort of minstrel; he sings to each person present in turn ertempore, and they answer him.

tắng or string, rope, made by plaiting or twisting nearly strands of fibre, grass, etc.; tẳng lăm lăm, těăng string made by twisting fibres over each other ; täng miā mǐār, one strand of a string; täng lŏk lŏk, plaited string; Wŏng chĕn těăng, Wŏng has cut the string, i.e. Wong has stopped the fight, or the matter under discussion; těăng kĕ chĕn tēr düm, his string is cut, i.e. his day is over, said of a lying mas; tă̈ng chŭk, the waist string (belt), for the knife; see, too, under tĕăng.

tăngzŭm . a wasp; tăngzŭm mă nyŏng pī, bě lě dŭng, if wasps sting anywhere, they hurt.

tăp or tĕp to break; pŭs tăp kēe, the sun has broken (bent) his head, i.e. it is after mid-day; tăp lĕ bĕ, lit. he broke, he pour'ed, he came back, i.e. he reduced, or gave away a portion.

tăp . . to take heed, be careful; to look after; ă-tăp ! look out! ă-tăp ghư̈-dă, look after, tend the 
goat; à-tăp kè ğhä, be careful with yourself-in the sense of clon't make a fool of yourself; to await, to look out, to look for'; në lŭ-tăp-chè, he saw a look-out hut (such as is put "l, on farms by ownels, to look

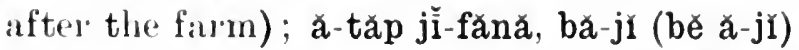
à-kăt gnăn, if you look out for my arrival, come and meet me; gnăn po tăp-kěnı = I anl looking out, or watiting, for him ; ăntăp kā. I don't cau'e, I don't mind; kè tăp bĭ sě kă, he doesn't mind what he eats.

tăpip. P.A. = the H.A. lāu, $\%$.

tăr or mad, illiotic.

tă-tăr

tăr .

at tall grass which spreads itself by feelers sideways, like 'llhoob' grass =H. barafia; an excellent foor for horses.

tăr . . a tree = H. gadagi.

tār. . moon, month; tār kē kè nüng, the moon seen in the ver'y early morning; tär ke gŭm, full moon; tār kè fwōm, the shape of the moon between half and full; tär jù lōm, hiılf moon; tār pwì, new moon; ăs kĕ tār, the morning star, also $=$ mwèlm bĭt; mŭ tăng tār tyěrk kwān, mŭ tēr găk lìs, mŭ nē tār-n pwì, we count thirty days for the moon, we sleep one, and then we see the new moon, i.e. from new moon to new moon, thirty-one days; seison, time; tār bōğhā, the season of rain.

tără . H. bareưa, 'Thompson's gazelle.

tăt . . to spin, to make thread out of raw cotton= H. kaldi; tăt pŭtŭk, to spin cotton into thread.

tăt . . to cut off, with one long motion, a strip of leather from the whole skin, as in cutting strips like bootlates, to sew with. 
tătưl . the ordinary small black ant, H. tururua.

a particle used after words to say, think, show, ete., analogous to our' 'that,' but it is more explicit and more neurly= 'viz.,' or' 'that is to say'; mă lí tĕ ă-mět, they say, that is to say, go, they say that you are to go; it is often used withont its verb, the latter', by the use of the ter, being understood; mă tĕ ă-mĕt, they say you are to go; in the cases where the verb is left out, tĕně. a lengthened form of tě, is used perhaps more often than tě; wăt-chě tĕ gwătăn, a certain thief, that is to say (or', viz.) Gwitan; ăn-măn gnēt tě kĕ küt sheükdă gnăn, I know well, viz. (i.e.) that he will finish the business for me; ăn-fwŏt ·do bĕ ăn-măn tĕ $\cdot$ dō kĕ kwămtăk, I heard a shout, and I knew, that is to say, it was the voice of so and so; Kărăng-mă năng păk gŭrm-mă tě lăp-mă, the Angass call the rest of mankind, viz. outsiders.

tē . . to beat, as a drum ; to clap, the hands; to blow, a horn; apparently to do anything that will cause a noise to dance to; tĕ băngā, to beat a drum; tē sār, to clap the hands; tē sōm-bī, to blow a hol'n; tē ğhĭt běl, to stamp the foot, on which are bits of chain, iron, etc., that clank.

tē . abundance; more than enough for oneself; gwǒ-dă bĩ mă tē nyĭ dŭng; kĕ sĕ kě düm kā, the man has abundant supplies; he eats, but they do not come to an end; chĕlèfănă-dă rīt dŭng, dăng tē-ng mŭn kā, my (cooking) pot is a very good one, but it does not give us abundance.

tē . . to break; tē pī or tē ār, brigandage. 

(grass), i.e. the bush caught fire accidentillly; see lŭk; ă-tē mă sār à? dìl you fall into their hauls; ; tē nü̆n ăm. he fell into the water' fwăn tê, rain falls; perluaps the same root as tê, to enter; bri tè nyí kā, he has no luck; to commence; tê lăp kè pì, he commencel to look aloout him ; tē chirr kě shrt chin, he commencel to work, or, he fell to the doing of the work.

tē! . an exclamation = 11. ashn! tē ! àyā? Hullo! is that so?

tē . . to enter'; tē kă dün, he entered insirle'; tē lú, he entererl the liut.

těăng or rope, string; also used in it general way for tâng the net used in trial by ordeal in catching game; ăn-pün tě̉ng-dă wŭn, ŭ-mět kěni pi peep, I (i.e. the heard priest) give you the net, go to the hunting ground; see also tẩng.

těn . . to knock down, press down = 11. denna : gōl kĕ těn gŏ-rōt băng, justice knocks over even the man it likes; gōl tèn wē? whom has the case

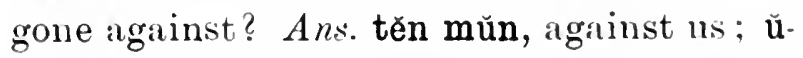
chrn bri-dă kü těn kě ğhk-mă, do this so as to press it down under stones; těn kworm, to press the ear, i.e. to turn the ear so as to hear better, to pay attention.

těn . . to sew ; bì tĕn, a needle, made generally of brass, and is of a linge size.

tèn. . the malaichi tree, the local mahogany.

těnè a lengthened form of tè, 'that is to say', or 'viz.,' and more generally used than te when the verb is unterstood; see tê ; tène pi mè dō dē? (they saý) viz. why is this?

têp . . the betsia (H.), duiker gazelle. 
tēr

to cause to lie down, to lie down; a-tēr nyı, cause him to lie down; tēr kwom, to lay back the ear's, of a hor'se; also of a calamity, to fall, or lie, on one; br̃-lè-müt tēr kè kē-nū, a dreadful thing has befallen us; lĭ tēr (for lŭ tēr), the sleeping apartment of a wife.

tèt . . to fan, to flap, as the wings of birds, etc.

tēt. . to agitate a bowl so as to mix up the contents; to shake, e.\% one's clothes to get the dust off (or drops of water); to dry up, as of dew (but not of water); tēt kē, to nod vigorously (once only).

tēt . . to spoil sport, to break up an assembly ; gwǒ-nĭ tēt gŭrm-mă dŭng, this man has spoilt the meeting.

ť̌ung. a tree; but especially the chertia, a species of fig, which is grown for its shade near erer'y house; it is called teūng furr, the courtyard tree; above, anything high up; por teūng, the sky; ă-kè teūng, climb the tree, and also, climb up.

teung dē . a euphemism, for a ransomed slave girl, who has married one of her own tribesmen and borne him a child.

tèzù . . the ordinary white ant; see chărn, which is capable of killing the big black ant $(\mathbf{H}$. guano), torng.

tī . . fiequently reduplicated tī-n-tī (H. tuntuni), formerly, long ago; dŏk-n-tī, some time ago. tĭlĭ . . a particle, very, very much; nük tĭlĭ, very thick, of body; mă jĭ mă kăng kē tĭlĭ, mŭ chĭn răng, mŭ chīr ē ? they (e.g. ants) have come and assembled in great numbers, what shall we do to change (it)? i.e. what shall we clo to get rid of them?=dŭng, but cannot 
always be used in place of it, e./. one cannot say, rit trly for rìt düng; whereas dŭng is always correct, tril is rather idiomatic.

tĭm . . H.A. = P.A. chŭm, black ore of any sort, e.! tiu or galena.

tim. . a long growth of hair, of beasts only, such as is on a goat's breast; a skin with long hair, given to a new king to wear lluring the ceremony of investiture.

tīntīn . . a leech; ăm-dă kè tīntīn kō kě dēm sūp gŭrm, there are leeches in the water, so they prevent men washing (gurm is in tho dative).

trpp . . black, or dark coloured.

trp . . the large bag or sack made of string for storing and carrying grain; its shape is like a water pot, with a wide boly and narrow mouth; it is only male in the Hill Angass and Sura, and is called chip by the P.A. ; such Hausas as know it call it dunku: " $f$. tĭm.

tir . . to tear, split with the hands; to slit; ăn-tir bănnè, I tore the leather apron; ăn-tīr răn kin, I slit (i.e. llew) a straight line. See tìt.

trs . . a nest; also the comb itself of honey, but not including the latter; bee's wax; also pronounced tüs.

tris . . to spit.

trs . . anything old, worn ont and uselesis, siuch as ragss, old thatch, etc.; kè bār třs, bě ŭ-lŭk, if it is worn ont, throw it away.

tìt . to split apart, as a sack; po kè kŭlŭk tît kō bi dün bwir yil, the month of the bag split, so that the contents were pourel on the ground; see tir, and the following.

tít . to drive a man or woman out of a family for misdeeds; shwăt nyì tīt gŭrm-mă àkŭk 
kā; păk kĕ chǐn sōt, dăng mŭ tīt mă dŕ, he (e.!. a heal man) does not expel people for nothing; some commit witchcraft, then we hive them out.

tīt. . well, properly; yē tītit, hold it fast, or properly, said to a newly dected king, who, when first offered the spear of office, makes a pretence of refusing it.

tĭtăn . an instrument of music of iron, consisting of two long bells, elliptical in section, joined togetler by an iron arch; the latter is held in one hand while the bells are beaten with the às kĕ tüs, a pig's tush; it emits a very cracked harsh sound.

tō or tŭtō to do a thing over and over aggain, to do it thoroughly; ă-gwŏk bă-tō (for bě ă-tō) kō nyı̆ lĕn d̆́, grind it thoroughly so that it is soft.

tō . . H. taushe, to squeeze, to grind (cornn, etc.), to rub hard; to speak clearly (?).

tōd or tōt gelt, used of rams or goats; tōd mā, tōd ğhü. See tǒt.

tŏk. . to talk; speech, wolds, discussion; mă tŏk gōl kě gwŏ-dūr kā, one does not talk law proceedings to a deaf man; shĕ speech; gwo-dă yē shĕ tŏk tŏk pi dŭng, the man has seized the conversation and won't stop; he talks the whole place out; pì tǒk, a whisper. See under pì.

trk . . a vegetable $=$ H. 7iubewa (ochra).

tok. . . (broad 'o' as in talk) H.A. for' chǒk, a neck; $c f$. tǐp, chĭp; and tĭm, chĭm.

torkjăn . a tree $=$ H. gurjia.

tōm . bloorl; tōm Wŏng, the blood, offered to Wŏng, by which an oath is taken; mŭ chět tōm kĕ 


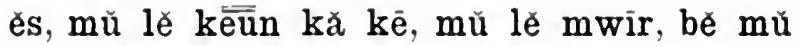
găs bě mŭ sě dăk, we cook hlood with flour, and add salt and oil, and then we ladle it out and eat it; fŭng tōm, a vein.

tom . the gruinea fowl.

tōm . bottom, foundation, cause; tōm kürr, the bottom, or foot, of the silk cotton tree; tōm kè sheurk tǒk, the origin of the discussion; tóm ké lěŏk-dă, the cause of the fight.

tōn. . weight, heaviness; heavy, thick; pī tōn-kënĭ lě dăng lām ăm, on account of its weight it fell and sank; tōn-kěni răng è? what is its weight? tōn-kěnĭ pó gŭrm kwān, its weight is that of three inen.

torng . to sit, remain, dwell ; tŏng shĭ bĭděr-ḡhā kwămăng, sit on your hunkers and tell me; to be sufficient; gwŏ-n Nyělăm mă torng mă yāl kō mă chŭn gwŏ-m-Păng-mă shĭ läk kā, the men of Nyelam are not sufficient to rise and fight Ampam; torng kăt-fănă kā, it is not enough for me, lit. it is not enough for my taking; the same may be expressed by tŏng kō wŭl dhŭr-nă kā.

tōr. . see chīr pǒ tōr.

tōrī . the baobab tree, H. kulia; gŏ-kēt kě sưm yrs tōrì, said of a man who in payment of at debt offer's in return something insignificant like the yĭs tōrì or the fibres of the linkice tree; when a debtor is tolıl kēt kè süm yĭs tōrī, his answel is dēr-chè dỉkā? is there not another day (on which I can pay?) = ale there not plenty of opportunities in which I can pay you?

tŏrüng. H. murufu, the cooking place on which the pot is put. 
tōt . to pledge, pawn; bì tōtōt, an article pawned.

tōt . . to pull up, pluck out, as grass, etc.; tōt fwip kì, to pluck a fowl. See töd.

tŭ . . to kill ; ăn-tŭ nyǏ shǐ săp, or, shĭ yĭn, I killed him with an axe, or, with poison.

tŭ . . to stir, in cooking; tŭ weer, stir the food; to stir up dissension, etc.; gwŏ-dă măn tŭkĕnĭ kă yŭl-kĕ-mā kā, the man cannot stir up their country.

tŭbõ . H.A. for tobacco. See tābā.

tŭgŭzŭm . a cloud of dust.

tŭkǒk . . to play, to toy; especially of a boy and gill together.

tŭktǔlĭ . mist, dimness, due to a storm or the Harmattan haze.

tūl . . a swelling; shĭ ăt-ăn (for ăt-gnăn) kō bār tül, (when) a fly bites me, it becomes a swelling.

tūl . . a water pot $=$ H. tulu.

tŭlăn . a shrub which has a very broad leaf, but not quite so big as that of the mwălm (H. ywaza) ; it gives a fibre for string.

tŭm . . to alight from a horse; to descend à hill; ăn-nē nyĭ kă tŭm tŭm, I see him coming down.

tüm . flavourless, of food, i.e. without salt or the other usual ingredients; pŭk n-tüm, the soup is tasteless.

tŭm . . smooth; chāl tŭm, a cheek without tribal marks cut on it; tŭm ān்-hā kě-n gār kā kō rit dŭng, smooth like this without edges (or projections) is much the best; (the Angass, for instance, prefer a round smooth box to a rectangular one with its edges and corners).

tüm . a new, unused calabash. 
tüm . a water rat (?) reddish, with a shaggy coat. See wŭl.

tŭm ol tüm H.A. for a sheep=P.A. mã ; ff. H. tumlica. tŭn. the red driver ant; the black species, shang, - is only known in H.A. not in P.A.; à-tēr lŭ, à-nē (n)tŭn pī rōt dō dă, if you make a house, and see the driver ant on the spot, the place is a good one.

tŭn . . any sort of hole which is dug; a grave; tūn ăm, a well, or water hole; deep; cf. H. tona, to dig (a well, a hole).

tün. . the 'tuo' or' mŭn dedicated for a sacrifice.

tŭng . to stir'; mă măn tŭng-kěni kā, kō pin chělě di, they don't know how to stir it, they'll break the pot.

tŭng . to touch; gwo-dă tŭng tŭng pĩ dŭng, lit. the man touches everything, i.e. he is continually interrupting; to massage; măt tŭng kum, the woman massages the umbilical cord, i.e. at the birth of a child; tung pī, lit. he touched the place, i.e. he touches any and every place or thing (see pì); $\cdot$ dõ tŭng $\mathrm{pi}$, the sound of things being tonched, as by

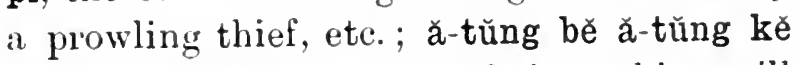
chĭn bí-chĕ kā, if you touch it nothing will happen.

tŭng . a white ants' hill.

tŭp . H. kada, to stir soup while cooking; bi tŭp, any flavouring added to soup; used with wèr (H. hunu), to prepare or cook gruel.

tūr. . to fighlıt; mă dār tūr kā, they lid not stop (i.e. want) to fight; gwro-tür, a pugnacious, quarrelsome man.

tür. . the trunk of the body, including the breast and ribs, thorax; pro tūr, the breast, chest; yis tür, the ribs. 
tūr

a shrub with soft white branches and trunk, and brilliant pink flowers; it has no leaves at the flowering time; its juice is used as a medicine for itch, and also as a poison to kill fish.

tŭrgŭl . the ankle bone, both the inner and outer one. tüs . an old stump of a tree; $f$. tis.

tŭs

in tŭs mǒs, the solid portions of the beer which settle in the bottom of the calabash, while drinking; note shishăk is the solid portion formed during the brewing, and turs is the dregs still left after the brewing is finished and the liquid is drawn off.

tüs . . a will pig.

tŭs . . to push; ăn-tŭs gŭrm-dă kō nyĭ tē-n-ăm, I pushed the man so that he fell into the water.

tūt . . a species of calabash $=$ H. livirtu.

tūt . . to get burnt, and so spoilt—of food; ă-y̌̆t b̆̀-dă kō tūt, you have let the thing get burnt; ăn-sě bì tūt kà, I can't eat a burnt thing.

tūt . . to smoke-of a fire; the smoke of a conflagration (the ordinary smoke of a fire=yil); ŭ-nē wŭs tūt-pănă d̆́, look at the smoke of that fire orer there.

ú- . . sometimes wŭ-for euphony is the pronominal prefix 2nd pers. plural; ŭ-mĕt, you go, you have gone, you went; go ye.

ŭăn . . (better wăn, q.v.) clay, earth fit for building purposes.

văng . . to wash—of articles, clothes, etc., not of the body, which is sūp; to circumcise ; mă văng 
jêb-mă, they have circuncised the boys. H. vanka; ă-văng băng băng, măn ă-yìt kă răp kã, wash it thoroughly, don't leave it dirty.

văng . a particle, used with chèn, to cut; chèn văng, cut it hard or properly.

vēng or (a long prolonged syllable) always, continually, vāng for ever; yèm kŭn kě lă shī kě pŭp vēng ké pi kworp (or yîl), the eldest son always succeeds his fither in the oflice.

vil . . the marrow, of bones.

vir. . a mole.

vit . . or oftener virt vít, is whirlwind.

vrilì . rhinoceros.

vŭk . to polish, scrape, or rub clean; ă-vŭk brüng

kō fwì nyì dō, rub the hor'se for its hair to fall out.

vurm . . to fold, or wrap, a thing up, so that it does not fall.

vŭm . . to wound, whether by a sword cut, a stab, or an arrow, etc.

vŭm or vŭn mildew, damp; r'ust.

vŭm . blind; a blind man; the latter is also govŭm.

vŭn . . a roan horse.

vŭn . mildew, damp, oozing damp. See vŭm.

vwăl . an accident; dōndōn gnăn pó mwěn, bě vwăl pǔt ăng (for gnăn) kō lě n-găn kwăn-běl kē dre, yesterday I wils walking when an accident happened to me, causing me to fall, so that I cut my head.

vwöli . . a tree $=$ H. maje.

wăk or better, rather'; ăn-tǒk kwőlm (bè) wơk annwok müt, than tell a lie, I would rather die. 
wăk ol' wǒk

wāl. . to cry, sob, lament; yěm pǒ wāl rōt wŭr, the child is crying for the breast; mă pó wāl těně mărăn mūt, they are lamenting, for the mistress of the house is dead.

wălĭlā . the small entrails (bŭshăng wărn=the large ones).

wăm . to spoil, be spoilt; năm kĕ bār wăm, the meat has become rotten; though wăm is practically the same as dūn, one cannot say năm kĕ bār dūn, but năm kĕ bār bĩ dūn(dūn).

wăn . clay; any binding earth fit for building, or making earthenware pots, etc.; also pronounced ŭăn.

wăng . . to go round about, to start aside, e.g. to aroid an ar'ow; pī wăng, a way of getting out of doing a thing; pì wăng dĭkă, there is no way out, there is no help for it; to make way for some one to pass; to wander, go off the road.

wăng . . hot water, not boiling.

wăng . . to winnow, generally used with kě shwē.

wăp . to swell; more generally wŏp.

wăp . . homage, obeisance, tribute; ă-wăp gwŏlŏng wărn, do homage to your chief king; it is also $=$ take your tribute to the chief king; ă-wăp kŭm-fā răng e ? what is your form of religion? mă lă wăp kō mă măn tě ŭ-chĕn dĭ-mă, they take your tribute, so that they may know you follow them, i.e. acknowledge their suzerainty.

wār . an aged white-haired man. 
wār . a single large black stone or bead worn at the neck (H.A.).

wărn . big, large; găntăng wărn, the large porch or house for holding meetings, etc.; gơwarn, a huge man; also in the sense of, great, important; gwölŏng wărn, a great (or powerful) kingr ; tār pó wărn pơ wărn, the moon is waxing (wane=băk).

wăt . theft, thief; gor-wăt, a thief ; mă yee gŏ-wătn-pār, bě mă tŭ, if people catch a thief by night they kill him.

wē? . P.A. = wā H.A., who? whom? to, w1, for whom? ă-rōt wēe whom do you like? cf. H. wa?

wē . . . to return, but it includes the idea of returning to one's home, to go home, to come home;

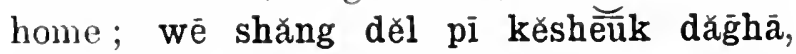
home is the pleasantest spot after all; wē shăng bŭl, home is indeed pleasant; sheّuk chǔn-fā kě düm bā-(bě ă) wè, your work is finished, so go home; to come out from, or to return to, according to the context; mă wē Chĭp, they have come from their home, Chip; gworng wê lŭ, the snake has come out of its hole (lŭ bĭ would be, out of a hole, not its own).

wèp . the dry season; por wēp, the beginning of the dry season.

wēr. . forbidden, illegal, taboo; sit kè lit wơng wēr matt, to enter the Deity's thicket is forbidden to women; năm kě mŭlūt wêr gworm-Bwirmă, gǒ-Tŭwăn-mă sè dí găk, leopard's flesh is forbilden to the people of Kabir, except 'Tuwan only; wêr mŭn kèt kět, it is absolutely forbidden to us; wēr kèt kèt tŭng kè măt kex gwro-chè, it is absolutely forbidden to touch another man's wife. 
wēr .

wèr .

beads, which are generally worn only round the neck; round the waist, they are worn by those who have seen the Hausas doing so.

wèr . to break wind.

wì gruel, II. liunu.

punishment, to punish ; ăn-wī-ghhā, I will punish you; măt-dă wī Wŏng, the woman punishes Wong, i.e. she ridicules him, saying it is only a man.

wŏdlőn . a telm of abuse; pŏ chŏk wŏdlŏn, a wobbling goitre; swinging; wobbling; applied to per'sonal peculiarities, as hydrocele, etc.

wǒk . see wăk.

wǒk . to frighten.

wǒk pŏ . to pretend not to want a thing, though really one does; to say a thing, e.\%., for politeness, but not meaning it; ăn-wǒk pr nyı̆ kō bărăk, bĕ lă sě dăk, I asked him (to join me) out of politeness, (to my disgust) he came and ate my food; ăn-kăt mă pǒ shwē kè mŏs, mă wǒk pŏ gnăn kā, I found them drinking beer, but they did not give me a chance of refusing-i.e. they did not even ask me out of politeness; the newly elected king always goes through the form of refusing to accept the honour till it is forced on him; he is said work por.

wðk . . better, rather. See wăk.

wǒkār . . the fan or deleb palm =H. giginia.

workăr. . the peculiar scanty dress worn by the Kibyen (Buliuru) and other men of allied tribes.

Wong . the local territorial god of the Angass, who exercises executive powers of punishment, as well as attending to the prosperity and welfare of his people - $c f$. the Israelitish Jehovah; it is also the name given by the 
men to the bogey (a man dressed and disguised, almost formless, in leaves), with whom they threaten the women to keep them in the way they should go. This latter Wong is explained to the women as the ghost of ancestors and other leceased persons; the idea is borrowed from their neighbours, chiefly the Yergum, and is foreign to the aboriginal religion of the country.

worng heat; hot; fever ; wonng kě wŭs tơng kā, the heat of the fire is not enough; ann-fwort worng kě pŭs-dă dŭng, I feel the heat of the sun very much; ăn-fwǒt tě nyí kām kā, sheük wong nyī, I hear he is not well, he has ferer.

wŏng chōn a bogey wơng, whose approach is made known by a peculiar whistling, obtained by means of a pipe; the women, however, are told that he blows his nail; the corrector of runaway wives; to this wong is performed the ceremony of ' jok k.'

worng djü- a male bogey, a worng which only appears once

korin in three years; the king or chief of all these worng bogeys.

worng găng the bogey borrowed from the ganng or Yergum; it appears at mors târ, on the commencement of the reaping season, clothed in guinea corn leaves.

Wong is the bogey which is supposed by the women gurna to be the incarnation of the Wong or the local Deity; it appears at the moss worng ceremony, i.e. at the commencement of the harvest season before sowing.

wong kărăng a bogrey of Ampam's.

wŏng yim the worng or clodo covered with madaichi (tèn) 
leaves (see wong); the women are told that it is the ghost of a dead woman.

wőp sometimes wăp, to swell, cause to swell ; ăn-sě bí-dă rīt kā, kō wŏp bŭt gnăn, I have eaten something not good, so that it has swelled my belly.

wŭjầ . a hippopotamus; mă chăn dăgă shĭ shı̆m wŭjāi, they make armlets of hippo skin.

wŭl to follow (a road); ăn-wŭl ār Gārū, I followed the roal to Garu (Bauchi).

wŭl . H.A. to reach, arrive at; gwŏ-dă kĕ wŭl kă pi-dă, the man will arrive at the place= P.A. rut.

wŭl . a sort of water rat (?) bigger than a house rat, said to be like tüm except that it is dark coloured.

wŭl with a domestic fight or l.ow, in words only, no lěŏk blows; scolding; pŭp pơ wŭl kě lěŏk kĕ yerm, the father is scolding the child.

wŭm . swollen testicles.

wŭm . . to bury; kō mă kĕ wŭm à ? have they buried (him)? Ans. mă kĕ wŭm, they have.

wŭn . . pers. pronoun, 2nd pers. plural, in the nom., acc., and dative cases.

wŭp . H. burgu, a species of large water rat, living in holes in the banks of pools; a bandi$\operatorname{coot}(?)$.

wŭr . a breast; wŭr sŭn, at flat-breasted woman (abuse); wŭr dō kām kĕ jěb mă yĕm pār, the breast is the strength of infants; bwot wurr, to leave the breast, to be weaned.

wŭrn . haste, speed, quickness ; to hasten; ă-wŭrn, make haste; mă jŭ kĕ wŭrn, they came in haste ; ă-mĕt wŭrn wŭrn, go quickly.

wŭs . fire; pĩ wŭs, a fire place, also used for the place where the king holds his court, as 
there is always' a fire there; dōn tī mŭ nē wŭs kā, mŭ kăt pơ nŭng-mă, dăng mŭ $\mathrm{j} r$ kenni kă yil, in the old diays we had no fire, we got it from a cow and brought it to our town; wŭs worng, the fire obtained by drilling at stick, such as the shaft of an arrow, through any pith, e.g. a gruinea corn stalk. The only form of obtaining fire known to women is from the flint and tinder, and the men keep the friction method a secret, and call it wuss worng, or the god's fire.

wŭt the wild custard apple.

wŭt . to turn a pot, etc., over and shake it so that its contents, such as mashed yams, will come out.

găk . . H. diba, to pick up, pick out, ladle out; yăk am fwor, ladle, or scoop up, water from the stream; yăk bŭp, to sinatch out fish ; ghürm fi torng yăk, the beans are sufficiently dry (ripe) to pick; ă-yăḳ bì-dă-mă mă lě dí. pick up the things that are spilt; yăk ăs, to catch hold of a dog, so as to prevent him rumning after anything, as in hunting.

yăk yỉăk . a term of abuse; a mad man who goes about naked.

yāl . . to get up, to rise; yurr-ă (for yurr-dă) yāl sŭ, the bird rose and flew; mă yāl lēôk, they rose to fight, almost = they sprang to arms; gworlong kě yāl băng, the king has finally risen, i.e. put an end to the audience; he only does so when he sees further discussion is useless, such as when litigants continue alquing after decision has been given; gwo. lơng kě yāl băng, dăng mŭ tơng mŭ chîn) 
mē dē ? as the king has gone, what is there for us to sit and do? fwăn yāl bìděr, the rain rises from the east.

yăng . a guinea corn ol other crop stalk left when only the ear is cut offi, see porteũs; yăng por lŭ, a door made of guinea cor'n stalks; pó yang, the boundary between farms, and so, also, between towns.

yăng . . to pierce; ğhŭr-dă yăng-ăn kō lě-ngăn dŭng, the thorn pierced me and hurt me much.

yē . . to seize, to catch; mă yē gwŏ-dă pŏ kēt, they seized the man for debt; gwor-yrn-mă mă yē-n shī, kō mă jŏm kĕ yĭn, medicine men catch bees, to mix with poison (or, with medicine); ă-yē nyı̆, keep it, catch it.

yē . an exclamation, H. ai; kĭlǐwŭs yē sōt-dă, I say! fire-flies are witchcraft! gwŏ-dă chin mĕ, dăng kĕ lă yē dē ? what has the man done, that he has taken ' $y \bar{e}$ '? i.e. that he is exclaiming.

yĕl . . to tempt; $\bar{g} h \bar{a}(\mathrm{~g})$ yěm-nĭ, ğhā gwǒ-yěl, Hi, you boy, you are a tempter (jĭgwěl-fā rìt kā).

yěl . . to tear, break apart, to skin, to slit, to rip; mè yěl dē dē? what has split the calabash? mă sě năm kā, bě mă yĕl shĭm-dă dăng, before one eats the meat, one takes off the skin.

yĕm . H.A. to be prolonged, to delay; bĭ-dă kĕ yĕm dŭng, the matter is of old standing.

yěm . pl. jĕb-mă, a child, young, of animals, m. or f., though yĕm-măt is generally used for the female; yĕm ăs, a puppy; yĕm tălit, a bastard; yĕm tŏng tŏng, a child of another staying or being kept as a pledge, in a house; yĕm kŭn, the eldest son, the heir; 
yĕm pŭ-nă, my brother (whose father is the same, but whose mother is different); yěm nĭ-nă, my brother (both our parents are the same); the latter is sometimes used where the father is lifferent.

yěndăl or the latter more frequent, also yěndăk, thunler ; yendăr yèndăr părp, the thumler crashed; gwo-dă nē yěndăr shí yît-chě, the man saw the thunder with another eye, i.e. a sort of second sight, said of a man who is struck dead by ligglinning; ă-nē fwăn kĕ ji, măn ă-tơng vwơli kăt, măn à-tơng tôm těn kăt, măn ă-tong tōm děp kăt, măn yěndăr tŭ à (for tŭ ğhă), when you see the rain coming don't stop under a maje tree, or a malaichi, or a dunya, lest the thunder kill you.

yăng . . in the phr'ase, kē kě shit bě kē kè yăng.

yěng . a tree, H. tufashica; it has red elible fruit.

yěng . . name of a bird with a large hearl.

yěng or above; bri-dă kē kě yěng, kō rît dăp kā, the

yä̈ng thing has got up high, so that it is not easy (good) to get; lit. it is not (a) good get (thing); kẽ kě shì bè kē kě yẵng, the heads of the grass show the direction of the wind (?).

yë-kŭt. . a tree=H. lokin, a very liage, tall, straight tree.

yēr. . a grain store; but specially used of at woman's grain store. See gyēr.

yèr . . . sometimes yirr, a bird ; kō-yěr-chě nyî kě sümkenni, every sort of bird has its (own) name; yěr lě ès, a bird lay's eggrs; chēp kě yěr, a bird's wing; fīp yèr, a feather; pő kě yèr, beak; yerr wejp, the harvest seasson bird, the 'coppersmith' barbet. 
yerrm or the gossiping time just before bedtime; gyerrm gossip.

yěrp charcoal ; àn-kăt yěrp dăng, kwăn-mèt kwolm ail, when I have got some charcoal, I'll go to the blacksmith; mă wŭs yĕrp shř jük, they make charcoal from the 'juk' tree; yĕrp wŭs, burning charcoal; also, its cinder's.

yěs . . excrement, dung; kün yěs, to go to the rear. y ěuk, yük, to build; mă yeùk lŭ shí wăn, they build a or yǐk house of earth; to do, make $=\mathrm{H}$. yi; dìde yeük tŏk băng mŭ lì mă kwăt, the chief has said the word, so let's tell them; y $\breve{\text { euk }}$ shit chin, he did the work.

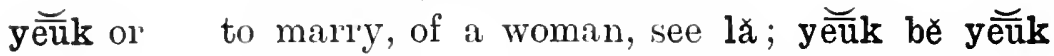
yük kā, lit. if she marries, she does not marry, i.e. she is unmarriageable; măt-dă mwěn yeük dŭng, the woman goes about making many marriages.

yĭ or yī a year', counted by moons, not by days; time; dǒk y̆-dă, wē (or wā) kě kwŏp è ? in those years, i.e. at that time, who had the spear? i.e. who was king? chĭn yĭ fïr, he is four year's old; y̆ dǒk $\mathrm{n}$-tī, in the days of old, formerly; dŏk yĭ kĕ Yăkŭbŭ bě à kā, formerly, in the time of Yakubu it was not thus.

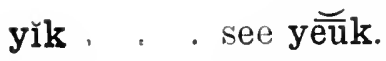

yil . earth, land, country; there are no towns proper; but when we speak, somewhat incorrectly, say, of the 'town' of Kabir, the word used would be 'yll'; sě yil, to eat earth, to salute; ăn-sě yul ğhā, I eat earth to you, I salute you; br yill, the thing of the land, i.e. the articles stored, the public treasury; all presents to the tribe, all arti- 
cles found ownerless, all tithes, etc, are put into the br yrl and are used, as required, for sacrifices, tribute, and other public purposes; yrll-dă kwār ğhk kèshěuk, kō rìt kā, the country is all gravelly, it is not good; yil kè düm, the world is finished, i.e. former times were better.

yll . sometimes pronounced gyll, smoke of a fire; also, of a burning house, or of a bush fire; à-fì wŭs-dă gyĭl tŭt gnăn dŭng, blow up the fire, the smoke annoys me very much; ă-nè yı̆l bè ă-măn wŭs dō dā, if you see sinoke you know there is a fire.

yrlm . to plant a tree for a special purpose, as for food, or shade, and to look after it, supplying water and protection against goats, etc., irrigated, specially tended, crops ; yrlm tābā, the tobacco patch; yilm kē, to allow the hair of the head to grow, oiling and tending it.

yim . a leaf; especially applied to the leaves worn by women; kworm yı̆m, leaves.

yĭn . medicine, poison; yřn-dă nyr kĕ băl gŭrm băng, nyı̆ tŭ băng (or nyì kĕ tŭ kwăt), medicine cures a man, and kills him too.

pin. . to remember, not to forget (the latter in the sense of looking after a family left helpless by the death of the breadwinner); gwo-da kĕ yĭn po tūr-kĕnir, the man bears them in mind, lit. remembers them in his breast.

yìn. . a little, aclv.; pūs yāl bìdēr yín, the sun has risen just a little, i.e. it is just after sunrise; ŭ-jī ŭ-dār yìn kō nyí lì dăng, come and wait a little (i.e. quietly) until he speeiks (to you).

yir . . a bird. șee yĕr. 
yĭr vertigro, gilliness; mŏs-ă (for mŏs-dă) yĭr gnăn, the beer has made me gidkly. $C f ́$. H. jiir.

yŭs. . a bone, a fish bone, fibres of trees; e.?. y̆̌s găng. yǔs tōrī; yĭs tĕp, a bone has broken.

yĭt. . to happen; mē yĭt ğhẻ (ğhā è)? what has happened to you? mē yĭt lŭ $\bar{a}$ ? what has happened to your house? i.e. household or family? = kăt, but is only used when followed by an object to which the thing has happened. See pŭt.

yĭt or yĭd. an eye; y̆̌t kĕ gwŏ-dă năn năn, the man's eyes are large; gwŏ-sōt-mă dăp yı̆t kě gwŏdă, mă dăp jŭjì kĕ yı̆t kĕ gwŏ-dă, kō vŭm dri, wizards destroy a man's eyes, they take the pupil so that he becomes blind; gwó-dă yit yit dŭng, the man eyes (it) exceedingly, i.e. he wants it very much; yĭt kyăng, a man blind in one eye, a squinting eye (?); yĭt vŭm, completely blind; yı̆t gĭgăl, large protruding eyes; yřt fĭblük, small deep-set eyes; yĭt ăm, a spring of water; y̆̌t shī, the ankle bone (the inner one only). $C \dot{f}$. H. ido.

yĭt . to allow, leave; H. beri; ă-yĭt mă mět, let them go; yĭt wŏk-kĕnĭ dı̆, kō mwĕn mĕt pì-chĕ-mwă-dă, he has left his house to wander about in other places; ă-y̆́t d̆́, leave it alone; y̆it kēe, to shake the head, in dissent.

yĭt . bitter, acrid; mors yĭt, bitter beer, such as is most liked; bŭt kĕ gwŏ-dă jĭt dŭng, the man's disposition is bitter'; gwŏ-dă bŭt yĭt

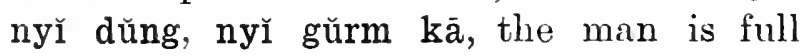
of bitterness (or, wickedness), he is not a man. 
yrt . . to separate dirt from fool by washing the latter in a calabash (and proceeding as in pauning for gold or tiu); à-mět fwor kõ yìt bì-dă, mán à-dūn, go to the river and swill the thing. don't spoil it.

yrt fwor a river flowing in a leep ravine; a ravine.

yơk . . to shake; ă-yŏk těung-dă lë-kěnr mă dō, shake the tree so that its fruit may fall.

yol . . . a loose outgrowth of flesh; e.g. the wattles of a cock, the two small growths under the neck of goats, a sixth fleshy finger growing from the little finger, etc. - a man with the last is called gwó-yōl; gwơ-mìs kì dō yōl nèt nyì dảk, it is the male fowl which has red wattles.

yōm . . dried wood, firewood; a tree cut down, timber ; yōm wŭs, firewood.

yōr. . and sometimes nenly dyōr, a scorpion; yōr ăm, a species of water criab.

yör. a species of wild cat, which lives only in hollows of trees.

yük . to build; to lo= H. yi; see yeữk; ăm găm fworr, kè pì děl kā, kè yük gŭl-gŭl, the water has filled the river, there is no place to ford, it is built up (in waves).

zăk . H.A. fol dō dā; nyí zăk =H. slì lie man, all right, it is so; gwö-löng zăk = gwó-lőng dō dá, this is the king.

zăl . . a rillge of a field on which crops are grown, also used of waves; àm-da chin zall, the water is rough (or' 'wave-y'). 
zăng a youth, f. ripp; time of youth; it also corresponds to our 'rashness of youth'; lă shr zăng, to take off a girl with the rashness, or headstrongness of youth, i.e. to elope with another's fiancée; pŭt zăng, said as a compliment of a fine well-grown youngster of twelve years or so; bār zăng, he has reached the age of puberty; dð̌k-dă nyı̆ pó zăng, in the days of his youth.

zăng . ridicule; ă-tǒk zăng ăng, you are ridiculing me; š̌t zăng gnăn=H. ya fitta mani la'a, he ridiculed me.

zăng . . an ornament; rīp po zăng, a girl is ador’ning herself.

zăr name of a large tree.

zăr good, appreciated; sheّuk zăr, a good, favourable talk or discussion; gŭrm-dă zăr, a good, popular man.

$z \overline{\mathrm{e}}$ or jwē . the mud or stone wall built between the round huts to make a complete enclosure with no entrance except by the găntăng; fŭng zē, the holes at the bottom of the wall to act as a drain for the water to get out.

zin . . true; truth; ă-tŏk zin bĕ ă-tŏk kīn, when you speak the truth, you speak straight (or, are intelligible).

zŏng . a deep pool.

zŭk. . a rat hole whose opening has been filled up by the rat with earth.

zŭm zŭm . a present; generous; gwŏlŏng kĕ pün zŭm laziness, lazy; gwö-dă chĭn bĭ-chĕ kā, zŭm dung, the man does nothing, he is very lazy. gnăn, shĕuk-chĭn-kĕnĭ zŭm, the king gave me a present, he is of a generous disposition.

zŭm the ordinary small black ants $=$ H. chinalia . 
zŭm

H. alheri, prosperity, good health, everything going well; ă-mwěn zŭm à? have you come well? a salutation to a stranger; yì-ni yi zŭm, this year is a year of prosperity; mŭn zŭm lěŏk, we are free from fight.

zŭm . H.A. for cold—of water' ăm-dă zŭm dŭng, the water is very cold.

zïm . the upper part of the back, the shoulders; ke züm used adverbially or prepositionally = after; mŭ mèt kě züm-kěnr, let's go after hin ; züm sār, the back of the hand; züm rŭs kŭm, lumpbacked; skin, rind, bark, shell; ă-pŏk (ol ă-fworlp) züm-kění, lit. take off its back, $i$.e peel it.

zung . the lianlii antelope.

zung . H. zonlio, a tuft of hair on the head; max man kwìp pī zŭng; zŭng bĭ sheŭk-chrn-kěmă, people know the Jukons by their tuft of hair ; this tuft is an inheritance of theirs.

zŭng zŭng authority, punishment; gwó-dă-mă chün nyÍ zŭng zŭng, kö nyĭ nŭng, the men exercised authority over, or punished, him, so that he miglit become sensible.

zŭzŭk for the Pleiades group of stars.

zŭkzŭk 

A complete collection of Foreign, Oriental and African Grammars, Dictionaries and Manuals is on view at the West-End depôt of Messirs. Kegan Paul, Trench, Trïbner E Co., Ltd., 25 Museum Street, W.C., London.

Lists on Application. 


THIS BOOK IS DUE ON THE LAST DATE STAMPED BELOW

AN INITIAL FINE OF 25 CENTS WILL BE ASSESSED FOR FAILURE TO RETURN THIS BOOK ON THE DATE DUE. THE PENALTY WILL INCREASE TO 50 CENTS ON THE FOURTH DAY AND TO \$1.00 ON THE SEVENTH DAY OVERDUE.

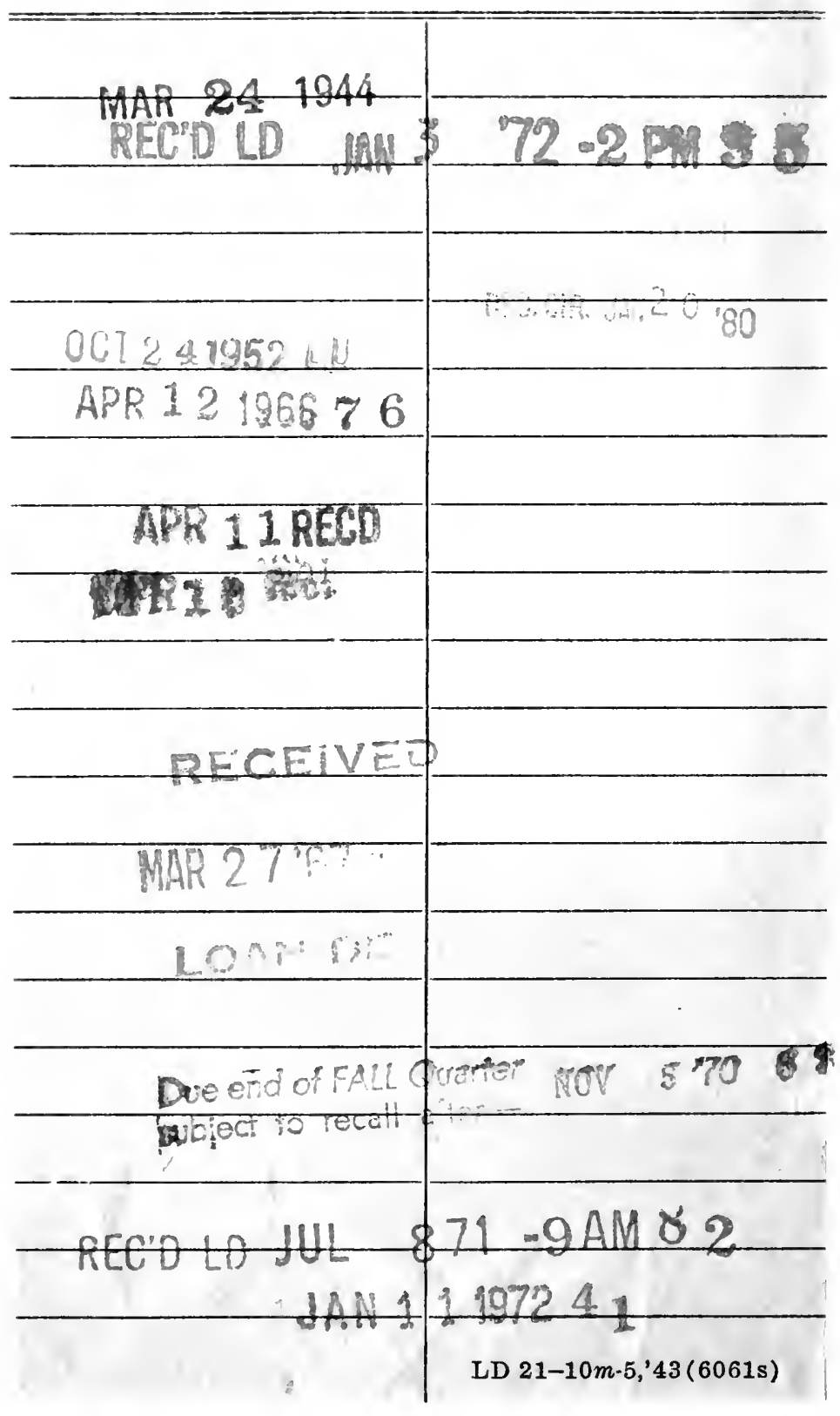


598437

\section{UNIVERSITY OF CALIFORNIA LIBRARY}

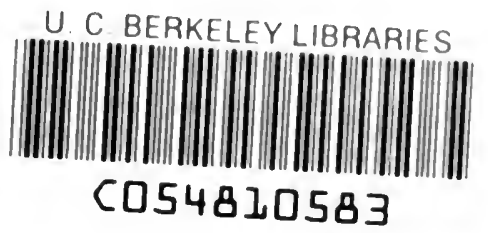


